\title{
Mechanical Engineering Department Technical Review
}

\author{
Scientific Editor: R. B. Carr \\ General Editor: R. M. Dennes
}

Manuseript date: Julỵ 1, 1981

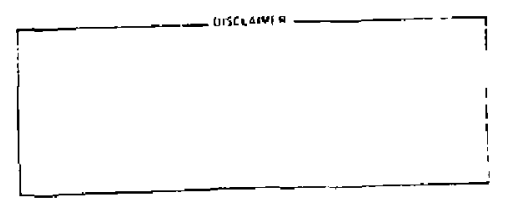

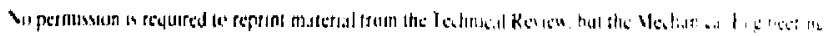

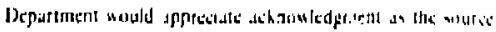

\section{LAWRENCE LIVERMORE LABORATORY} University of Cullifornia • Livermorc, Callfornia • 94590 


\section{PREFACE}

The Mechanical Enginecring Depariment Technical Review is published to iniorm readers of various technical activities within the Department, promote exchange of ideas, and give credit to personnel who are achicving the results.

The report is in two parts: technical achievements and publication abstracls. The first is divided into seven sections, ont for each division in the Department.

These technical achievement articies are summaries or ME work. For additional details on a subject. please contuct the individual(s) listed at the end of cuch article. Inasmuch as most projects are the rescrlt of cooperative cfforts. the article contact may refer you to another individual who can best answer your question.

The secend part of the biannual Technical Review sontains the titles or abstracts of laborator! reporls published by Mechanieal Engineering personnel since the previous issuc.

The ME Technical Review Committec members include

R. B. Carr. Depuy Department Head

1. W'. McCauley. Niuclear Test Engineering Division

D. W. Ruvenscroft. Nuclear Explosives Engineering Division

J. II. Pits, Energy Systems Engineering Division

C. W. Ca usen. Wujpons Fngineering Division

$\therefore$ A Cordill. Engincering Scientes Division

c. D. Lece. Magnetic Fusion Enginetering Division

H. H. Humpal, Materials Fabrication Division

R. U. Denney. Teuhnical Edilor 


\section{CONTENTS}

\section{Nuclear Test Engineering Division}

Dynamic Response of Epoxy Plugs in Nuclear Test Emplacenent Holes

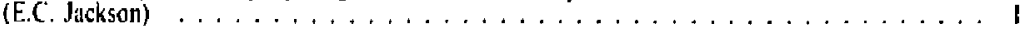

Atlas Truiler Shock ]solation System Conversion Nears Completion

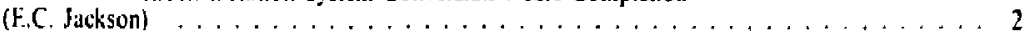

A Concept for Underground Nuclear Power Plant Siting to Retain Postaccident

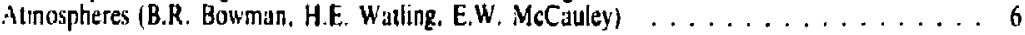

Processing Techniques for Data from the GKSS Pressure-Suppression Experiments

(E.W. McCauley) . . . . . . . . . . . . . . . . . . . . . 9

Eualuation of the Stismic Integriay of a Plutonium Händling Facility

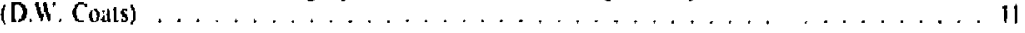

Dynamic Seismic Analysis or Unit 4 of the El Centro Stcam Piant

(R.C. Murray. T.A. Nelson) . . . . . . . . . . . . . . . . . It

Development of Probabilistic Seismic Failure Relationships of Nuclear

Components for the SSMRP (M.P. Bohn. L.E. Cover) . . . . . . . . . . . . I6

Preliminary Results of Thermal Igniter Experiments in $\mathrm{H}_{2}$-Air-Stcaln Environments

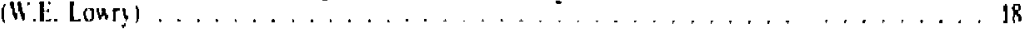

Lead Combination Program to A:d Nuclear Pomer Plant Design

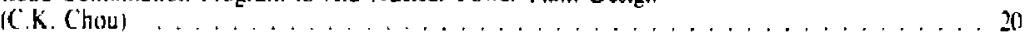

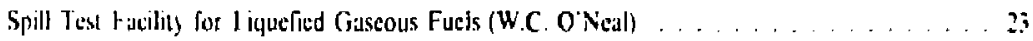

\section{Vuclear Explosives Engineering Division}

liveramerc Flame Experiment Simulites LVG Spill and lgnition

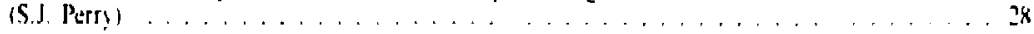

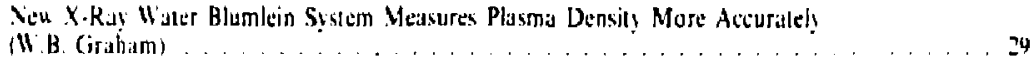

Strtss Rupture Test Sistem Deveioped for Compusite Pressure Vessels

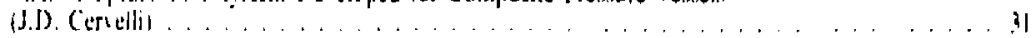

Weapuns Engineering Division $\ldots \ldots \ldots \ldots$

\section{Energy Systems Engineering Division}

Vew Mechanical Jechnology Warks Design of the Rova Lasier Styitern

if Ilurley!

Wicroradographic Ststem Descloptd to Measure Latsor Target Ball

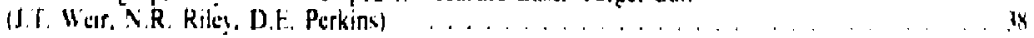

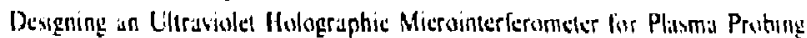

(1..L. Pictic)

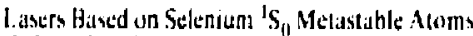

(B.R. Sichlescher. H.T. Pou elld)

Atoustit Alteriuation in the Closed-Cycle Test-Bed L.ustr

(J.M. Dulin. J.W. Dickic)

Design ol the Mats Experiment to Prose Economical Enrichmant

a!' listisum (Y. Osler)

Discharge-Healed Copner Vapor Laser Heal Shisld,

(T. W. Alger, W. J. Benett)

\section{Engineering Sciences Division}

Developing a Fatility for Fatigut and Fracture Testing of Stainless Stecl

Weldments and Base Metil at Liqu'tid Helium Temperitures

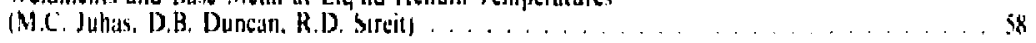

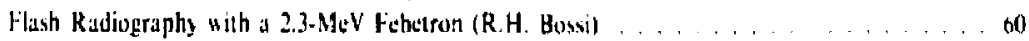

Holographic Evaluation of Composite Structurat Buikheads

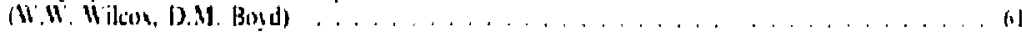

The Use of Pulstd light Sourtes to Chafacterize Malerials

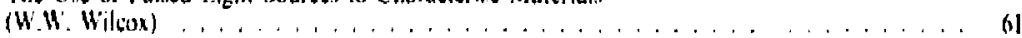


Flywheel Energy Storage Systems for Use with Photovoltaic Power

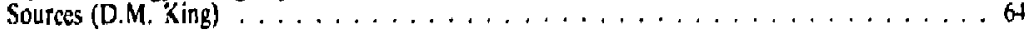

Concentralor Optical Geometry Diagnostics of Large Installed Arrays Using

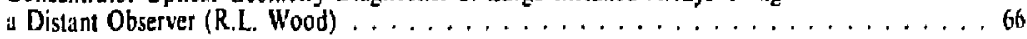

Compositc-Laminate Rotor Development (S.V. Kulkarni) . . . . . . . . . . . 68

Study Conducled to Determine Feasibility of a Toroidal Traction-Drive

System (D.N. Frank) , . . . . . . . . . . . . . . . . . . . 69

Ulteasonic Inspection of the MFTF Magnet Cover Welds (B.J. MeKinley) $\ldots \ldots \ldots \ldots 7$

\section{Magnefic Fusion Engineering Division}

Development of High-Field Superconducting Magnets for the Next

Generation of Mirror Fusion Research Facilities (D. N. Cornish) . . . . . . . . . . 75

First Pair of MFTF Mugnet Coils Nearing Completion (T.A. Kozman) . . . . . . . 77

Instrumentution Requirements in Planning Stage for the Magnetic Fusion

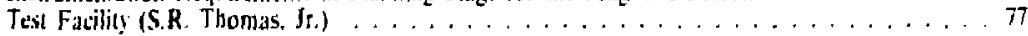

Studies of Magnetic Fusion Reuctors Point to Commercial-Scale Designs

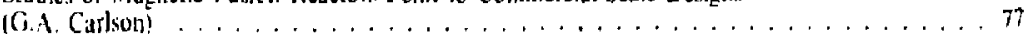

Engineering and Construction of the Advanced Test tecelerutor is on

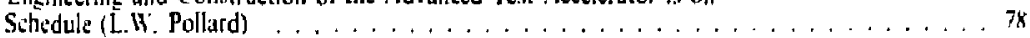

Synfuels from Fusion: Producing Hydrogen with the Tandem Mirror Reactor

and Thermochemieal Cycles (R.W. Werner) . . . . . . . . . . . . . . 79)

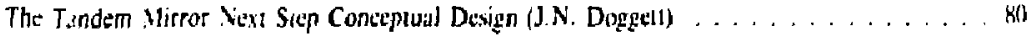

\section{Materials Fabrication Division}

Imercan Welding Society Presents Awards to Tuo Members of the

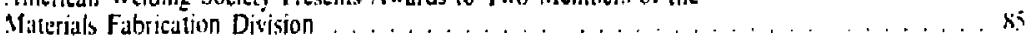

Laminar-flow Dampers for Stabilizing the Behavior of Pneumatic Vitsration

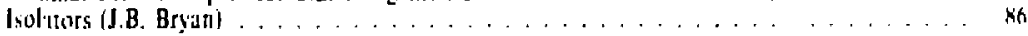

Electrochemical Joining of Dissimidar Metals (J.W. Dinii) . . . . . . . . . . . s7

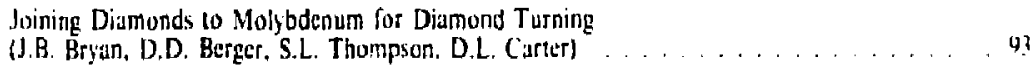

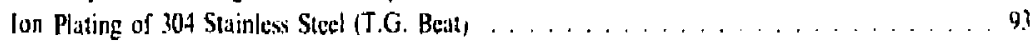

Publication Abstracts $\ldots \ldots \ldots \ldots \ldots \ldots \ldots \ldots \ldots \ldots \ldots$ 


\section{NUCLEAR TEST ENGINEERING DIVISION}

The Nuclear Test Engincering Division (NTED) provides mechabical enginaring and ecchnical expertise to prepure and field nuclear test. und to conduct analytitul and experimental studics involving nuclese sulety in general and secsmic response of resctors in particular. In addition, we suppori numerous Laburatory energy programs and the Furth Scienees (K) Division experimentul work. Thi NTED also provides mechanical engintering survices for spill effects testing at $C$ hina l.ake and NTS under the Liguefied Gaseous Fuels Program.

\section{Nuclear Testing}

Our nuclear testing activitics and responsibilities involve the design, structural evaluation, fabrication. and proof testing of diagnostic and device canisters that position radiation detectors and protect nuclear explosives in an underground environment. We emphasize efforts to improve data quality and field operations, optimize cost effectiveness, and maximize safcty. We synthesize. procure. and certify the arming and firing systems. The underground diagnostic systems that we previde require development and fielding of downhole emplacement systems. We develop containmem systems to meet zero detectable radioactivity release requirements. In addition, our advanced development projects include new diagnostic techniques and field engineering coneepts designed to oplimize stemming plans and procedures, and de"slopment of appropriate design and analysis methods.

\section{Reimbursable Programs for the U.S. NRC}

The safety of nuclear power plants and ussociated fastilites is the major concern of the Nuclear Regulatory Commission (NRC). We ate responsible for providing sisund technical data on which NRC can base licensing decisions and assessment tools to protect public health and safety. In this multidisciplinary effon over the past 6 years we have been engaged in more than 60 scparate NRC reimbursable contracts. In our work most of the facilities of the nuclear fuel cycle have been considered from the structural integrity viewpoint, including fuel processing and fabrication, accident analysis (particularly containment systems), interim waste storage, and spent fuel reprocessing. Our work can be grouped into three categories: seismic engineering, applied mechanics, and systems engineering and risk estimation.

A general goal we have is to establish LLNL as at national and international center of scismic excellenee We are currenlly NRC's lead laboratory conterning seismic safely.

\section{Energy Programs}

We provide mechanical tnginecring support to many of the Laboratory's smaller energy programs and to a number of scientific projects in the eurth sciencess lields. Some of our current efforts include work in solar thermal. solar fuels, oil shisle, geothermal. underground coal gasification, radionuclide migration. spent reactor fucl storige. and geophysits reselatch. We have responsibility for designing, building. and operating both lihorators experiments and off-site field engineering tess.

\section{Dynamic Response of Epoxy Plugs in Nuclear Test Emplacement Holes}

During preparation for several events in 1979. high diagnostic cable loading was ohserved in the stemming operution. inferring that the upper cost tar epoxy (CTE) plugs had moved. On inother event, Norbo, the upper CTE plug moved after the evert. This movement wiss later determined to have occurred bectuse of poor plug athesion to the surface conductor wall.

As a comselguente ol these suspeeted CTF. plug movements, plug nedsurements were performed on three 1980 events-Cis/wich, kash, and $\left.T_{i} T_{1}-0\right)$ Pathult Mesa all the Nevidal Test Sile. We those these tents wo provide full-sidt meisarentents for rebitivels larege ground motions in order tor moduce maximum inpu leials into the upper CTE plug in the surlike conductur. The expanded experinients insluded stemming and plug mcisurentsnts during the scomming optration and tontertuing through 
shol time. The overall configuration of these experiments is shown in Fig. I. Numbers in prurentheses in this lext refer to specific lacutions as shown on the figurc.

Static (before the event) and dynamic (during the event) plug displacentent near the center and wall oi the plug were measured with stiff rods (pipes) extending to the susfitec (55, 56). Stutic disnlacements of the bottom part of the plug $(53,54)$ and the sterrming just below the plug $(51,52)$ were measured restative to the emplacement pips. Emplacement pipe strain (83) and dynamic displicement (84) wete alsa measured. Accelerition and velocities w were measured in the plug (21) and in the gevound near the surface (6)). The aceeleralion of the surface conductor was mbilsured at iwo locutions $180 \mathrm{deg}$ apari $(62,63)$.

The stemming and plug displacement gauges (51-56) were released and displacement data were recorded at the earliest possible time to ensure that we measured their full history. The stemming displacement gauges $(51,52)$ were released before the rigid CTE plug was poured. Immediately after the Flug pour, the displacement gauges (53-56) in the plug were released. At this time the plugs had not cured, but the gauges were supporied by the gravel used as filler in the CTE plug.

Measured results from all three events showed gend apreement. The follow ing Colwisk results alte typlas:

- Lipon release. there is a 0.1-10-0.2-in. setllement of the stemming displacement gaveses [Fig. 2(a)). Alter the CTE plug pour, the stertming compats 0.2 to 0.4 in. During the nexl 3 to $7 \mathrm{hr}$. 0.1 in. additional displaticument occurs.

- The gauges in the tower part of the plug settle 0.2 ifl. upon reluase [Fig. 2(b)] and then sell le out with an additional displacenent of 0.1 in. within $8 \mathrm{hr}$.

- The upper p. et displacement rods setilic 0.4 in. into the uncured CTE plug upun rultuse [Fig. $2(0)]$ betause of their heilsy weight. An additional dieplacentent of 0.1 in. vicurs wilhin $8 \mathrm{hr}$. Aliet $8 \mathrm{hr}$. all displacement transduters renain conslant unil thot-induced motion vecurs.

After zero time, the first motion observed at Surface Ground Zero (SGZ) is when the emplacement pipe moves upward. When the ground shock compressive wave passes the stemming under the plug, the stemming consolidates and is no longer in contact with the bottom of the plug. As the upper layer of ground, including surface conductor and CTE plug, falls back it impacts a lower layer of ground. At this time, the plug dynamic displacement averaged 0.3 in. during the Colwick Event [Fig. 2(c)]. The plugs then return to their original position. A series of horizontal bands, each 2-in. wide and painted at the top of each plug displacement rod, provided mechanical verification that the plugs were not permanently displaced during the event.

The SGZ ground motions on all three trents uere withis the predicted ranges. Peak positive velocities were 5.1 to $7.4 \mathrm{~m} / \mathrm{s}$. with peak negitive velocilits from $7.4108 \mathrm{~m} ; \mathrm{s}$. Peilk accelerations in the ground were $5.3107 \mathrm{~g}$ inilial and $12 \mathrm{lo} 36 \mathrm{~g} \mathrm{im}$ piact al spalf closurce. Puak atcelerations in the surface conductor and rigid plite were louer than thes: in the ground 4.6 to $6.2 \mathrm{~g}$ initial and $4.6 \mathrm{lo} 18 \mathrm{~g}$ all impict.

The imptel energe involved in these experiments was up 10326 times the impate energ! experrienced on the Norbo Event. "hich verifice that propersy installed CTE plugess renujin an possiliun under sectere dinalmic conditions.

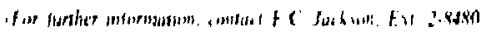

\section{Atlas Trailer Shock Isolation System Conversion Nears Completion}

Nucke:ir test information and data stre condilined or securded an electsume equipment. This relatic dis irapille equpment o houred in trailers and must survise the seters threc-dimenvional ground

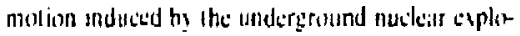
sion.

Before the NTf D wils furmed. eyuipment ws

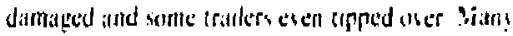

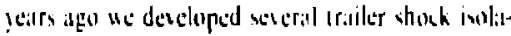

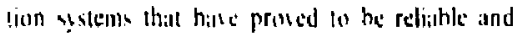
hilve allowed documented net sibng of approwintatel? anc million Jollars per y ear. When properly installed, these sisterns halse w thlstend I 3-it aertical

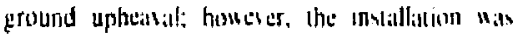
labor-inlensive. In 1977 ne desgenced il new sistem (1) ateomandade a more ellicitent meshod of prosiding shotk ahworption-lhe sulas Trailer Shuck lsolitson (ATS)/ ntitern. The ATSI design

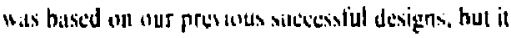
reyuised in onte-time retroblil to saith trailer strust ure. 


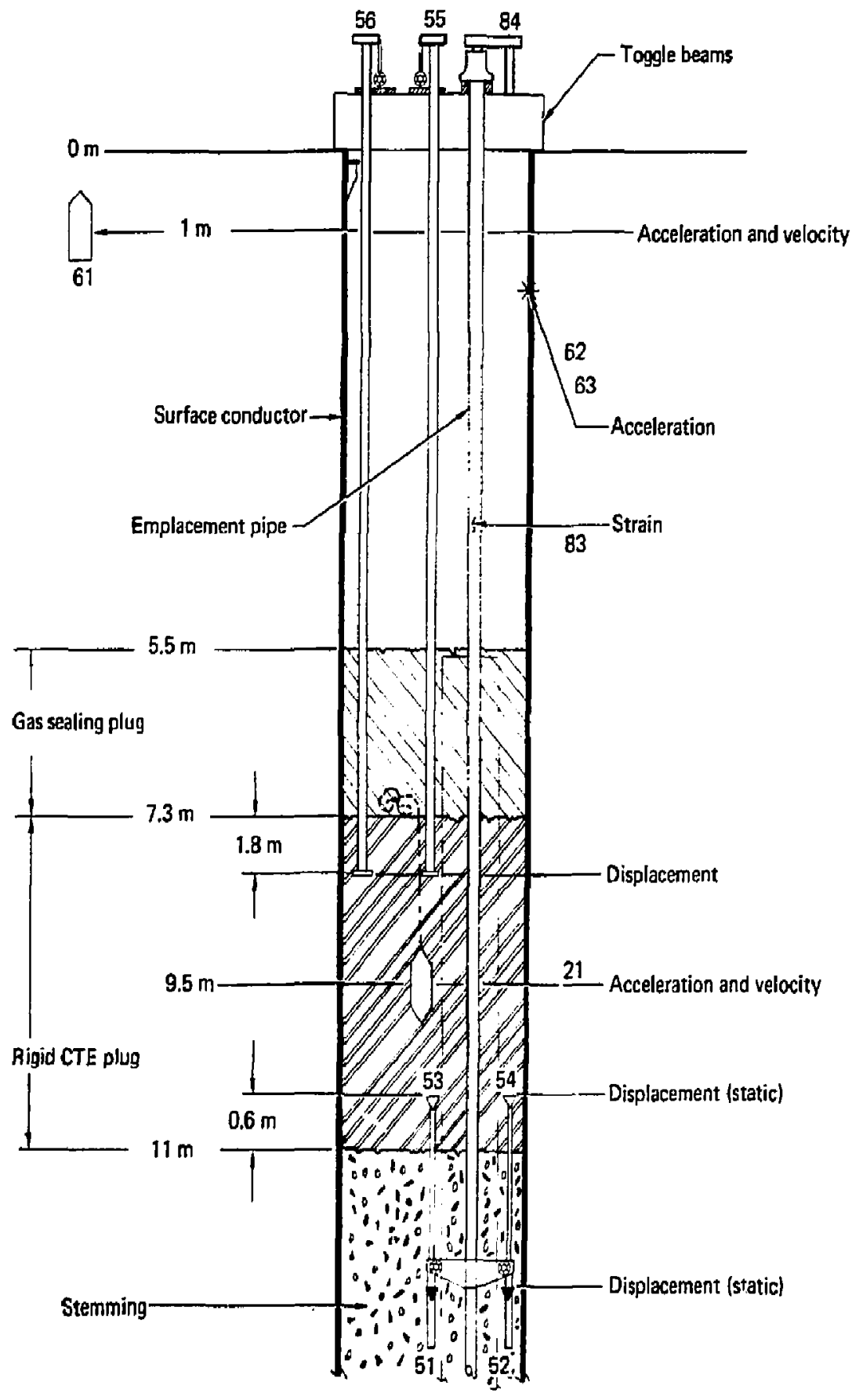

FIG. 1. Sclucuntic swowing locatios of iestrumenation used to mensure the static and dynamic worement of the CTE plas in line sarface comdector throushourt its installation and during ite even. 


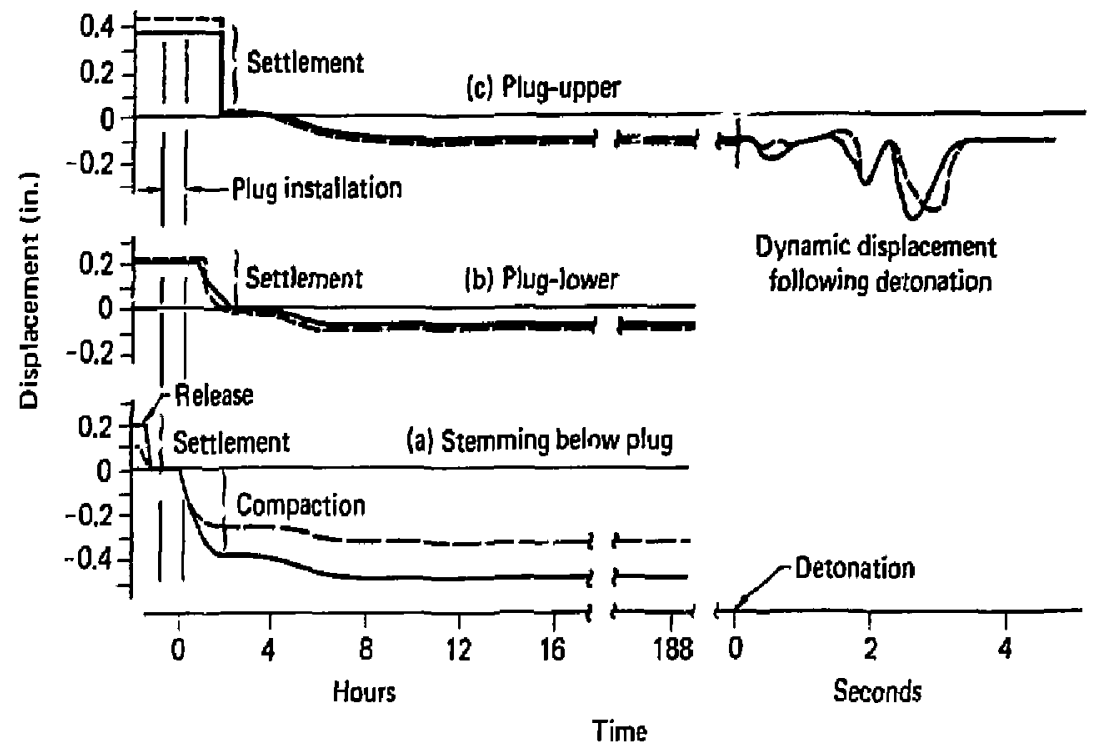

FIG. 2. Measured displacements in the CTE plug and the st.mming immediately beneath it for the Colwisk Erent.

The new system reinforces the trailer structure and allows it to accept inlerchangeable slandasd support modules, In all cases. the road gear suspension system remains on the trailer. Structural modifications to the trailer include: (1) transverse rails to increuse the trailer structural strength and guide the interchangeable modules into place; (2) reinforcement cross beams as required: (3) reinforcement along the length of the trailer; and (4) a stundard attaching bolt-hole pattern.

When the diagnostic teailer atrives at the trailer parth. it is placed in proper location on its landing legs. The modules ( $395 \mathrm{lh}$ tusth) are unlouded with is hudrocrane ard immedialely slid hallway inlo posilion on the Irailer. The crane is unbooked. the module is pushed all the "ay in. and lwo bolts are instillted. For retalitely low ground molicn. the module is installed in its straight (S) mode and a

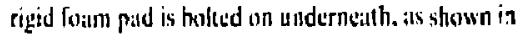
Fig. 3(a), To withutand severe ground motion. the module is installed in the column (C) nowde depicted in Fig. $3($ h). For the $C$ mode, the final assembly sejps are: (1) position a low-friction foot piod and plywood spicer disks: (2) inserl a columm from ahowe through the module and ino the fool pad where the column is relained by spring elips: (3) raise the trailer afproximately $4.5 \mathrm{ft}$ : (4) insert foum crush pads and wrap with filament lape: and (5) lower the trailer unto the crush pads.

Because of heavy event schedules for the trailers, their availability for the conversion work was a major problem. Although each retrofit took only about a month at our EG\&G North Las Vegas facility, we had to phase the work over a 3-yr period. However, all but two of the 35 adapıable trailers have now been converted to the ATSI system. With the new system, we have experienced more than a $50 \%$ savings in man-hours per trailer per event, and have increased ovẹrall reliability with a reduced quality assurance effort. Man-hour savings per trailes for high-yield shots average 110 , and for low-yield shots, 30 man-hours. We estimate that the ATSI system decreased the operational costs of shock-mounting trailers by approximately 5200,000 for calendar year 1980.

One of the converted shock-mounted trailers is shown in Fig 4.

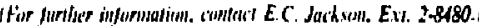




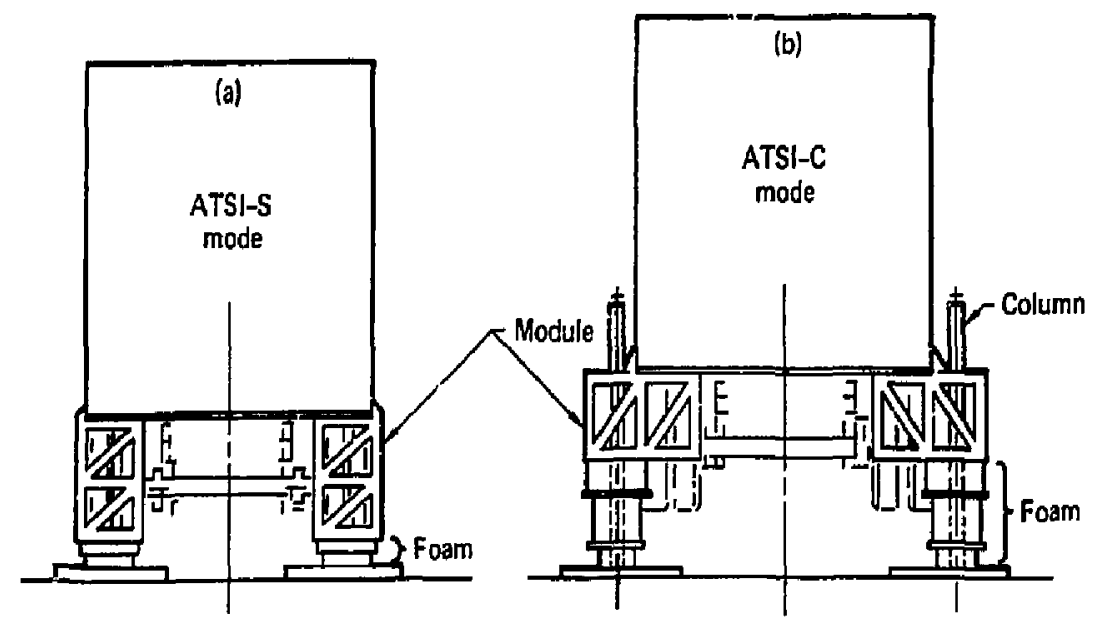

FIC. 3. (a) Small vertical displacement conligusation, and (b) large vertical displacement coninguration of the Atlas Trailer Shock Isolation (ATSI) system trailer conversions.

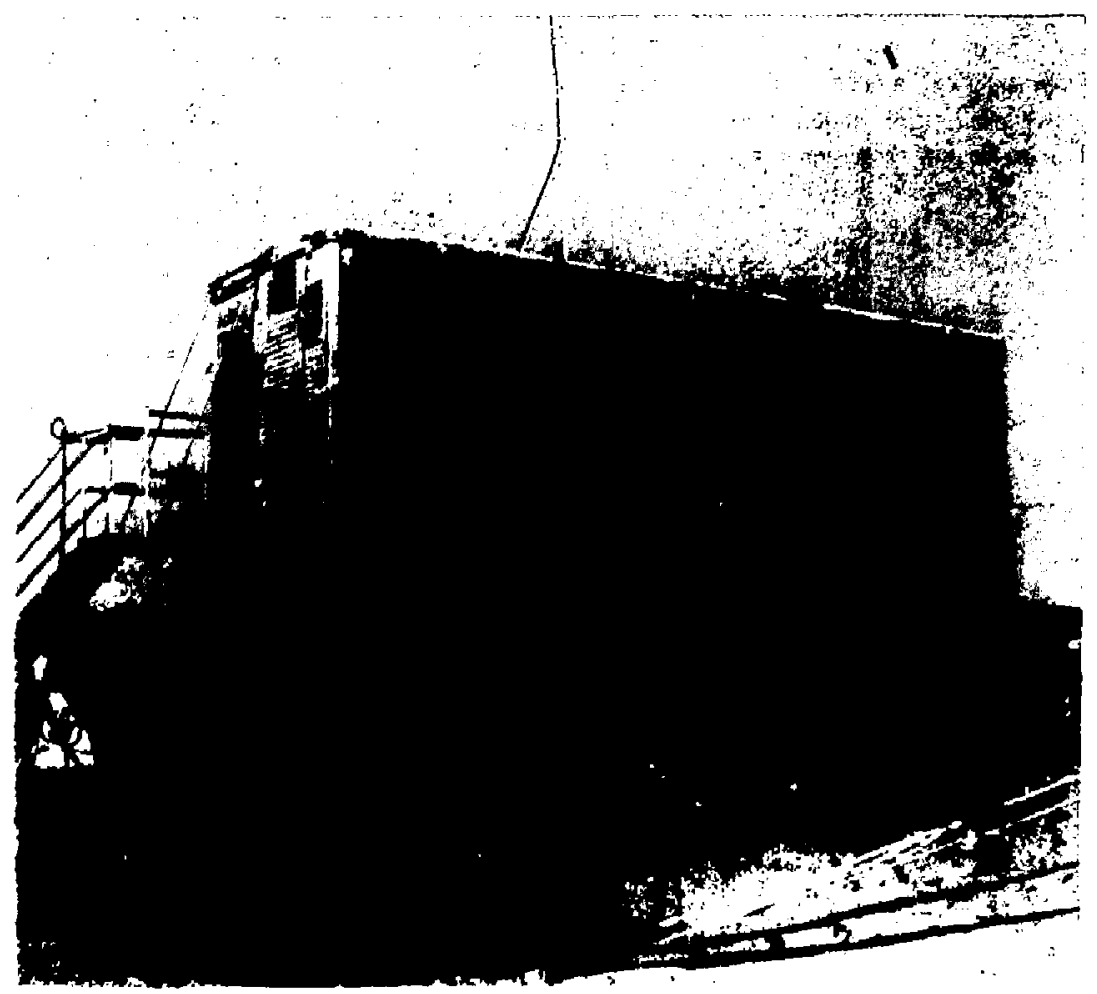

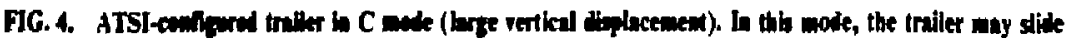

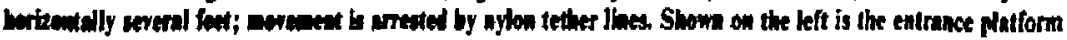

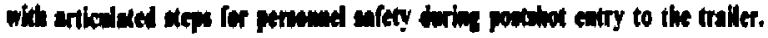




\section{A Concept for Underground Nucleạr Power Plant Siting to Retain Postaccident Atmospheres}

Preliminary design criteria developed for a general case 1100-MWe power plant show that underground siting of nuclear power reactors is practicable and safe. 1,2 The concept calls for open-pit excavation in any geological medium to allow construction of the reactor containment structure (Fig. 5). A desirable depth of excavation for the containment building and steam generutors is about $90 \mathrm{~m}$. Afier construction the pit is back rilled with selected earth material as shown in Fig. 6. The backJill is designed so that it will confine, within a smill envelope, any radioactivity releise that might result from a ruplure of the containment structure. To complement this "natural" hatrriter to release of radioactivity, techniques for effective closure of the large system pipes (Fig. 7) and for cuble gils blocking (Fig. 8) are applied from experiente guined in underground nuelcar device testing. The additionil cost of putting the nuclear portion of the system underground is only a small fraction of the cost of a cenventional, surface nuclear power plunt. Location of the turbine generator sels underground represents an unner ssary additional excavation cost so it is recommended that they be locuted at or near the surface. Underground reactor siting (us proposed herein) will apparently require no new lechnology.

The results of this sludy should still be regarded as preliminary in demonstrating that underground siting is a viable alterrlative to present practice for nuclear reactor power plants. It shows, however, that underground installation can be accomplished with existing technology, much of which has been developed from extensive analytical, experimental, and field experience on the underground containment of nuclear device testing.

If the conclusions are supported and the underground reaclor becomes a viable alternative. overall plant consiruction time could be materially rectuced by shortening the lime from plant proposal to receipt of construction permil. This time alvings would result from simpler (fister) revisw for licensing. made pussible by the increased inherent safety.

As a result of this initial study, the following conclusions are drawn:

1. By siting large power reictors underground in suilubly back filled excavations,

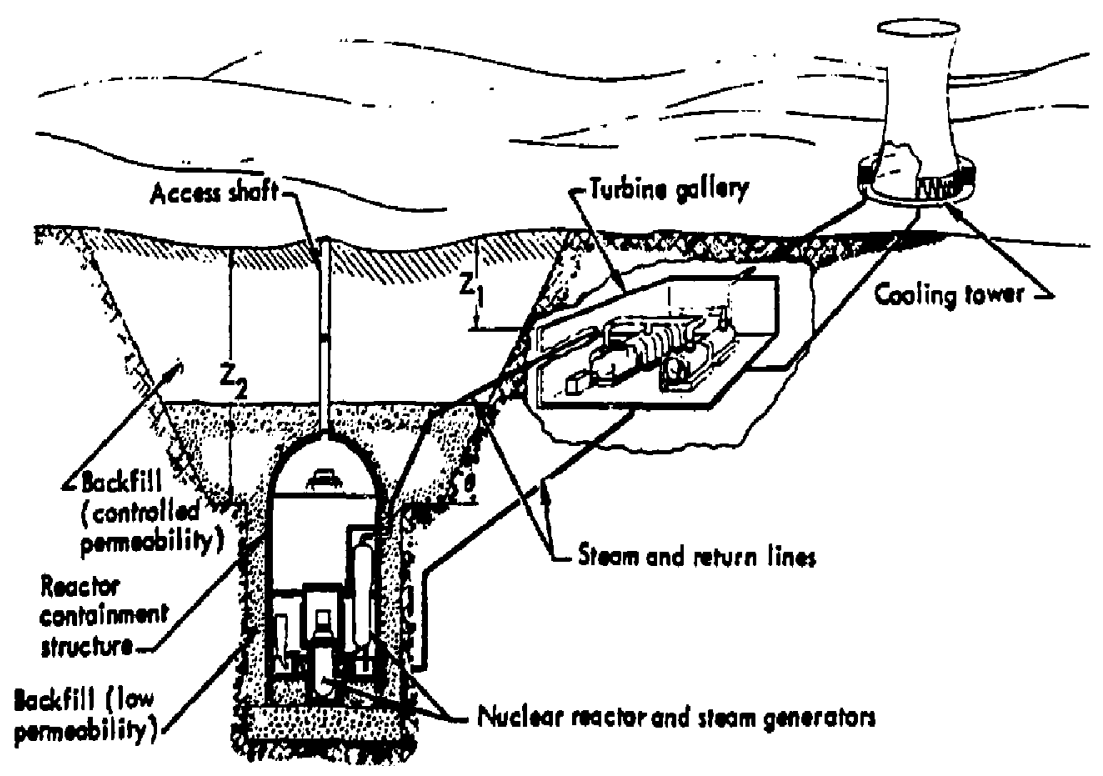

FIC. 5. A concept for underground siting of nurlear power reactors. 


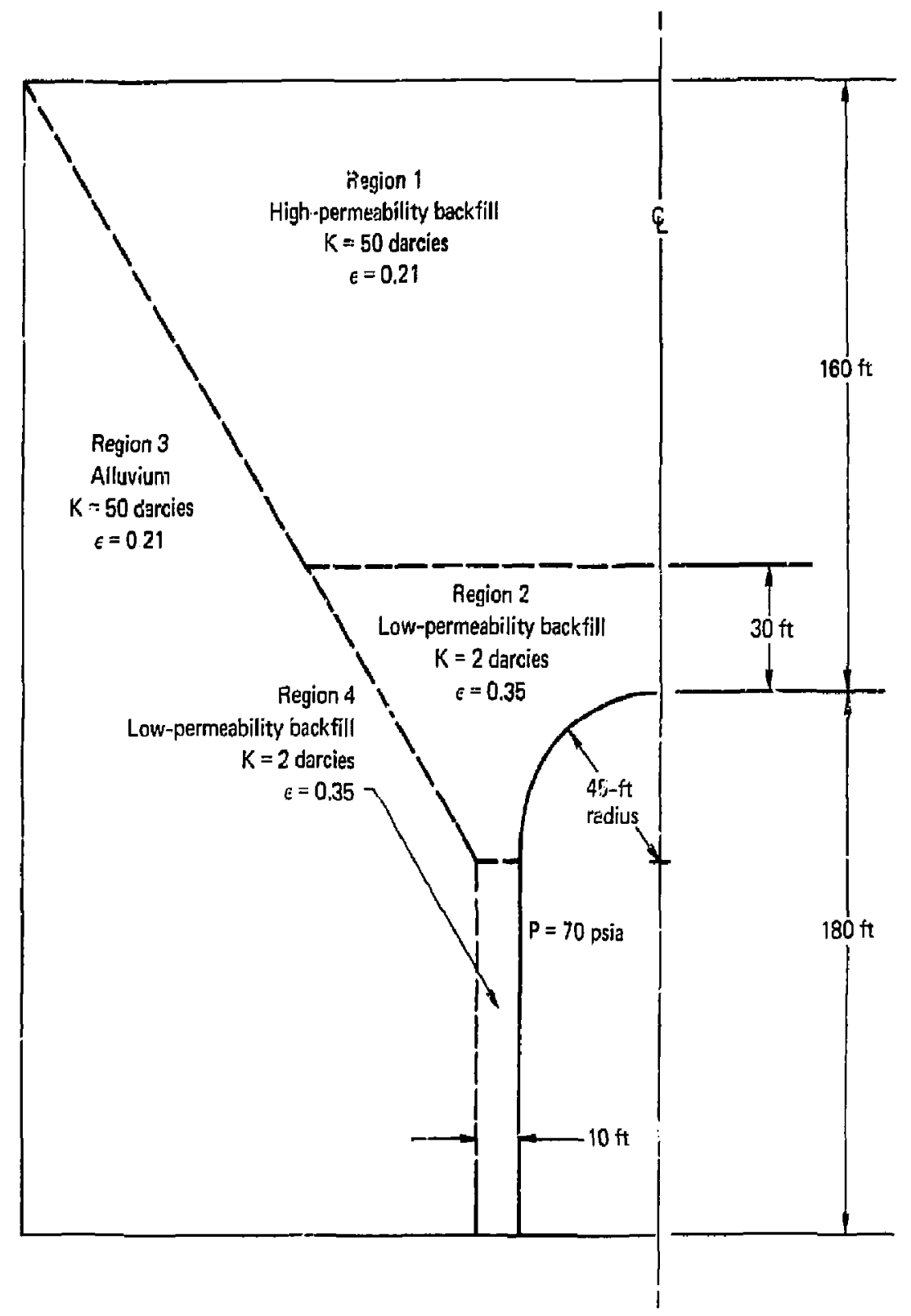

FIG. 6. Zoning for lat-permeability backfill design. 


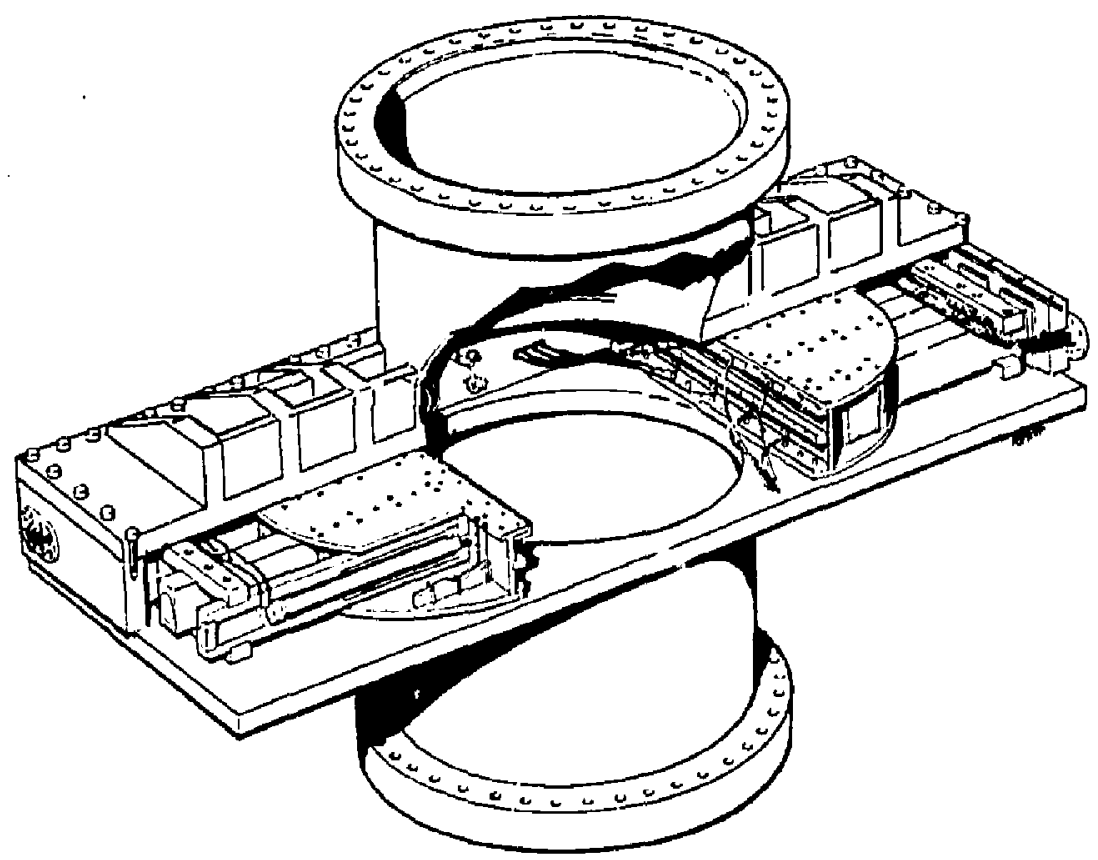

FIG. 7. Typical ti:gh pressure geisoperaled talve.

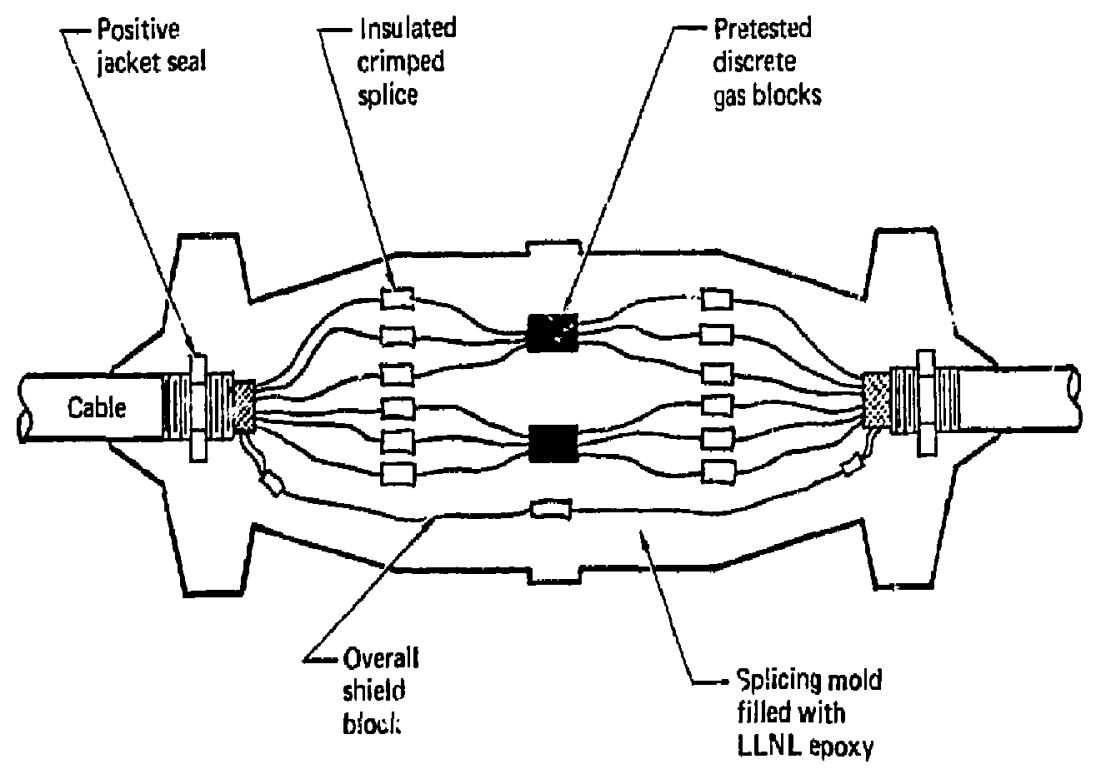

Fic. 8. The cahle gas hlock. 
harmful radiation frous the worst-tilse possible ateiderit sall be confined.

2. Underground siting in the nlanner proposed appliss lo any lype of light water reactor.

3. The additional costs of underground siling arc negligible. In fust, shortened construction times dut in reduced tuvironmentil-impact effects san bu expected, with consequent cost sissings.

4. Closure technology developed for contiannient of underground nucluar kesis is directly applicuble to underground siting ol reisetors.

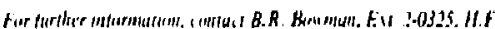

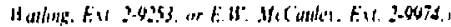

\section{Processing Techniques for Dala from the GKSS Pressure-Suppression Experiments}

This summary outlines the techniques developed at the LLNL for processing data from large-scale steam-condensation experiments being performed by the GKSS* Rescurch Ctnter in the Federal Republis of Germany. In particular the compuler code GKPLOT. a special evaluation program for gentrating time-history plots and numericil oulput files of GKSS datil. has been developed, together with cape handlisg techniques required to unblock the duta to a form compatible with the LLNL. Octopus computer network. Using these data processing techniques. we have provided a convenjent uneans of independently examining and analyzing a very extensive dalit base for steamcondensation phenomena. In addition, the techniques developed for handling the GKSS data are applicabie to the treatment of similar, but purhaps differently structured, experimential data sets.

The GKSS Research Center (GeesthachtTesperhude, Federal Republic of Germany) is currently engaged in a reseurch program concerning the response of a boiling water reactor (BWR) pressure-supression system (PSS/.to the late-time steam-conderisation pizase of a postulated loss-ofcoolant accident (LOCA). ${ }^{3}$ Such systems are an integral part of an overall BWR safely program, both

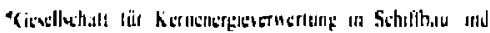

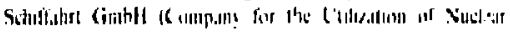

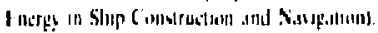

in West Germany and in the United States. The Lawrence Livermore National Laboratory (LLNL) has been designated by the U.S. Nuclear Regulatory Commission (U.S. NRC) as its principal liaison for this test program. Particular emphasis is placed on developing contirmatory data to assess the containment performance of General Electric Mark II nuclear power plants in the U.S., and to develop a comprehensive research data base for advanced code validation and further understanding of steam. condersition phenomena. The multivent GKSS test facility (Fig. 9), which was placed in operation in February 1979, provides a full-scale, three-vent pipe system that models the basic leatures of both the West German Kraftwerk Union (KWU) and th: Type 69 Uniled States GE Mark II pressuresuppression systems. The time-correlated messurements system ${ }^{4}$ consists of one hundred twenty-eight $100-\mathrm{H} z$ and fifly-six $1.7-\mathrm{kHz}$ digital-data acquisition channels, ard six $40-\mathrm{kHz}_{2}$ analog channels. Visual data is also collected by three $50-\mathrm{Hz}$ television cameras winich view both the water surface and the vent pipe oullets, and a high speed (1000 frames/s) |6-mm camera which views one vent exil.

The range of parameters treated by this extensive instrumentation system is brosd. Primary emphasis is placed on the messurement of pressure and temperature throughout the facility, although Diher paramelers such as water level. force. strain. and acceleration are also studied.

As part of its liaison attivities with GKSS. LLNL routinely receives magnetic compuler tanes containing digital data* recorded for cach lest in the research program. Management of GKSS data at LLNL is undertaken in three successive steps:

- Unblocking of the original duta tapes supplied by GKSS into a single packed.ASCII forsilal disk file compatible with the LTSS (Livermoie Time-Sharing System).

- Redistribution of the dalia among sereral smaller disk files to e.ahance datia manageability.

- Accessing the data (interactively or au!omatically) to generate time-history plots, or to gentrate numerical inpul for subsequent data analysis (e.g., frequency analyses). A typical time* history plot is shown in Fig. 10.

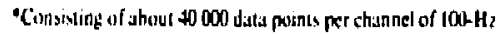
dita and about 7?0000 duta points far channel of high specd dalis. 


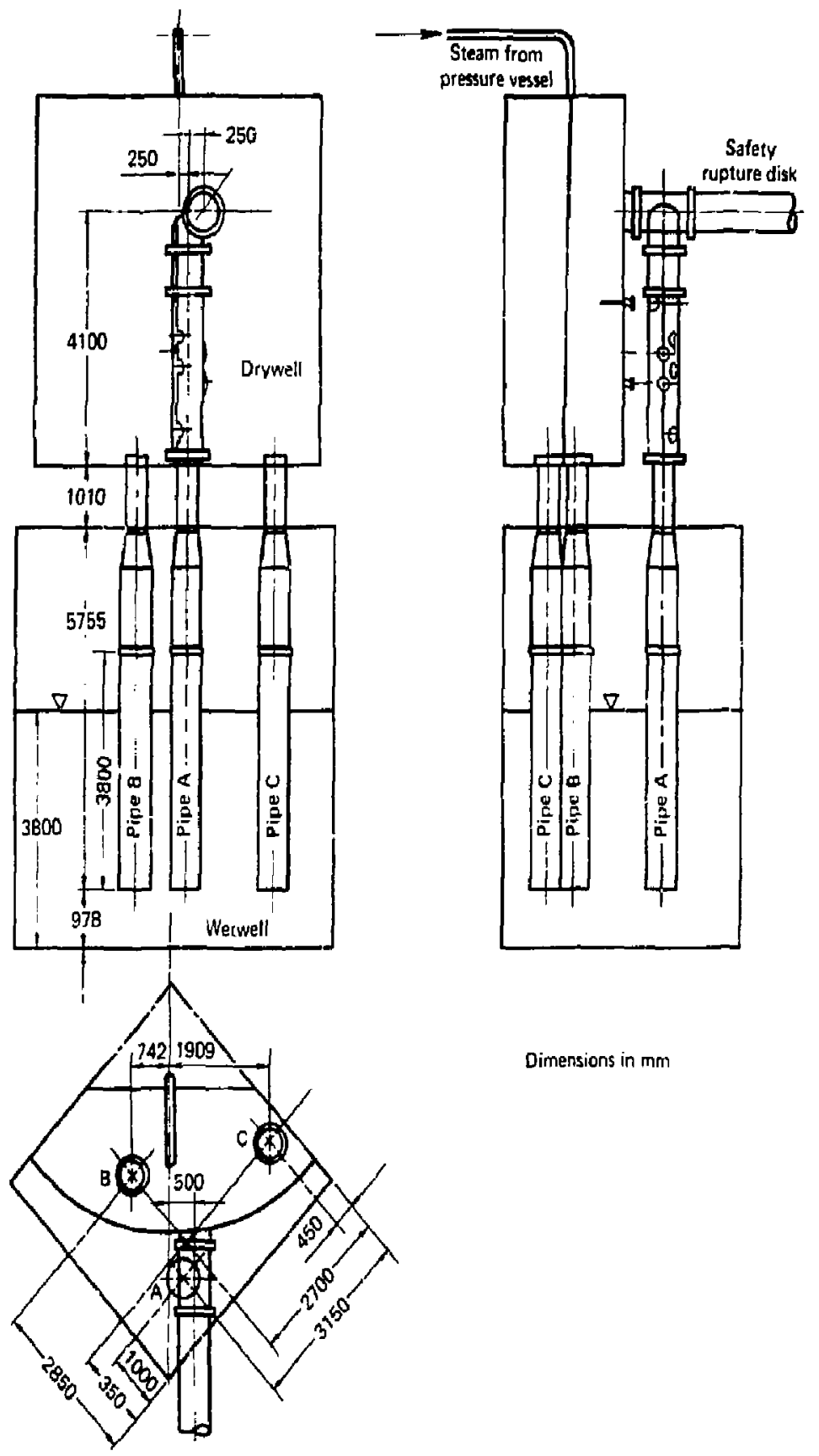

FIG. 9. The GKSS multivent pressure-iuppression tent facility. 


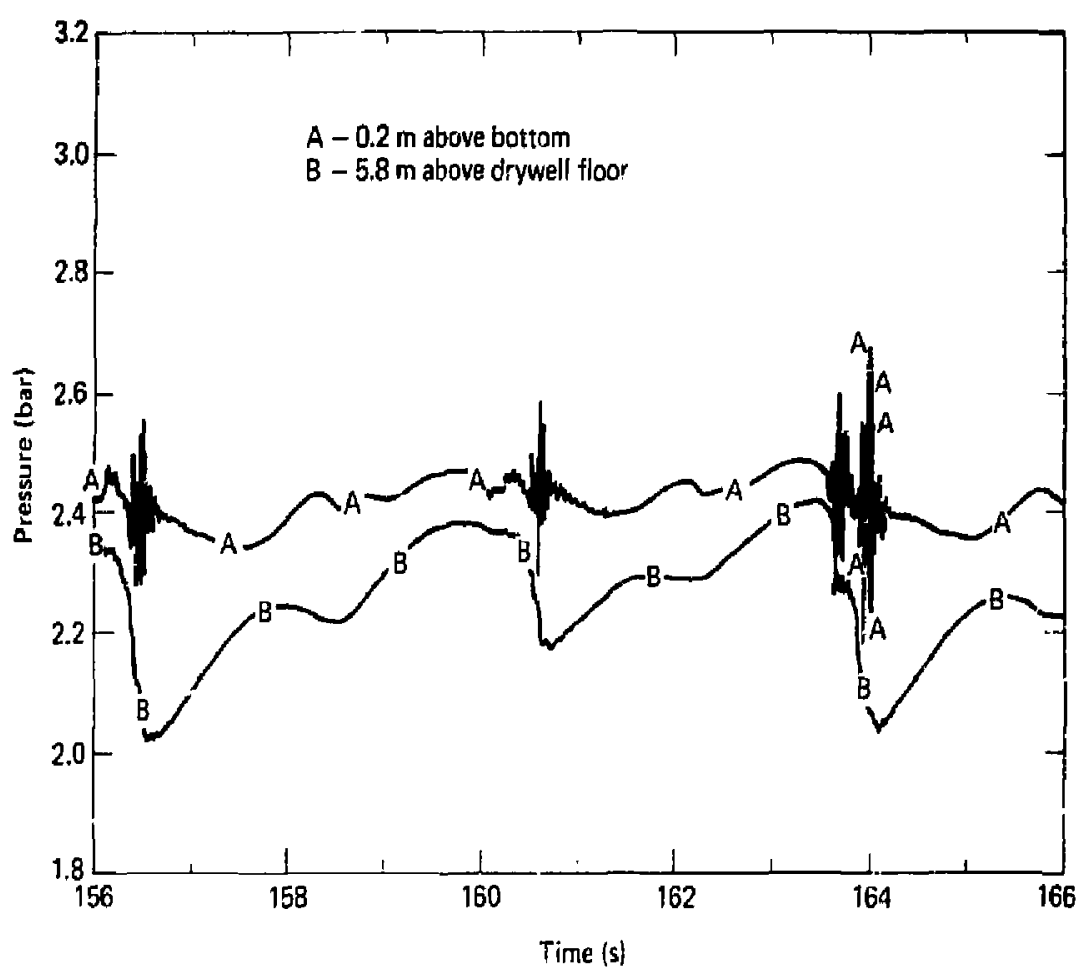

Fili. IIl. Onerlay pressurt-tinte history plot.

The first tus steps are only performed once for Lach dati set. sestuling in standard sets of inpul files for the LLNL dala atccess softuare. Thus, under rormal circumstances the original ditta lapes from GKSS are hundled onls once.

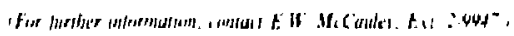

\section{Evaluation of the Seismic Integrity of a Plutonium Handling Facility}

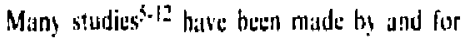
the Las rente Livermore National Linoritory (LI.NL) to ensurt the seismi: sifety of its Plutonium Fusility (Building 332). These sudies hise included stismologic and geologic ficld alvestigations to define the actual wis. nic hazard existing at the Laboratory silte is well as strutituril studies of the factilit itself. Becisuse the basic sasmic design criter la bare undergene changes over the !tils, numerous wl rud ural studies and upgerdes halve hecrl completed. The seismic crilerla in use at the LLNL site is resiewed on a continuing basss as new infurmation on the seismicity and geology of the Livermors Villey is obtined. Al present, the Laburator! : Earth Scientes Divisun is conducting a multimillion dollar program to identify and chits:cterize the geolugic halzards at the Livermore site, with the primary emphtasis on earthquake hasards in the Livermure Valley. This effor: is undergoing an independent review by WoodwardClyde Associates of San Francisco, Calif. Additionilly, beciuse of increised concerns over the seismic safely of Building 332. the Laboratory has iritiuled an independent structural review. This effort will be monitored by the California Seismic Safely Commission (CSSC) to ensure independence of the revicis. Both of these studies are in their early stages and :esults are nol yet available. 


\section{Plutonium Facility Description}

The Laboratory's Plutonium Facility was built expressly for handling plutonium. In plan view it looks like two buildings with a narrow cornection between them (see Fig. 1I). Plutonjum is handled only in the Facility's radiouctise inalezials arta, In. crements 1 and 3 . Increment I includes offices, a mechanical-equinment room. dressing rooms, plutonium laboratories, and a loft that ho, ses the ventilation syslem. Inerement 3 includes the corridor and air lock, a small control room, the main plutonium storage vault, four large laboratorics, and a basernent that houses mechanical equipment, the ventilation system, and emergency power and water supplies. Intrement .. is a minos addition is the corner where the connecting Increment 3 structure meets Increment 1. The plutonium handling areas are reinforeed concrete. sheir-wall construction.

Functionally, the design of the Facility is based on erecting multiple barriers to the propagation of fires and to the formation and release of plutonium particulates. These barricis are gloveboxes, the ventilation systern. and the structure of the briilding itselli.

These harriers, logether with the safety mcasures adopled in operating the building, constitute the protection LLNL prouides both to Laboratory employees and to the public againsi the potential hazards of plutopiem.

\section{Seismic. Design Busis}

Thet Plutonium Facility, Intrement 1, completed in 1961, was designed and buill in accordance with the Uniform Building Code. After the San Fernando. California, tarthquake of February 1971, LLNL examined in detail the sejsmic hazurd for the Laboralory site. ${ }^{5}$ An independent engineering and geology firm was engaged to carry out both a scismologic and geologic ficld investigation of the area. ${ }^{6}, 7$ from this investigation, it was concluded that the maximum ground motion at the site would be a horizontal acceleration of $0,5_{\mathrm{g}}$ with no evidence of a potential for surfacc offset near the PJutonium Facility. This 0.5-g maximum horizontal acceleration and a response spectrum were established as the design-basis eurthquake* for the

The devign-basis earthulake for at site 15 defined at the eurthquiste thut will produce the muximum posible grosnd motion at the site, s/ter which structures, sy dems, and components iniportunt to safety associated with factilitics that house radiosalive miterials must stmein lunctional.

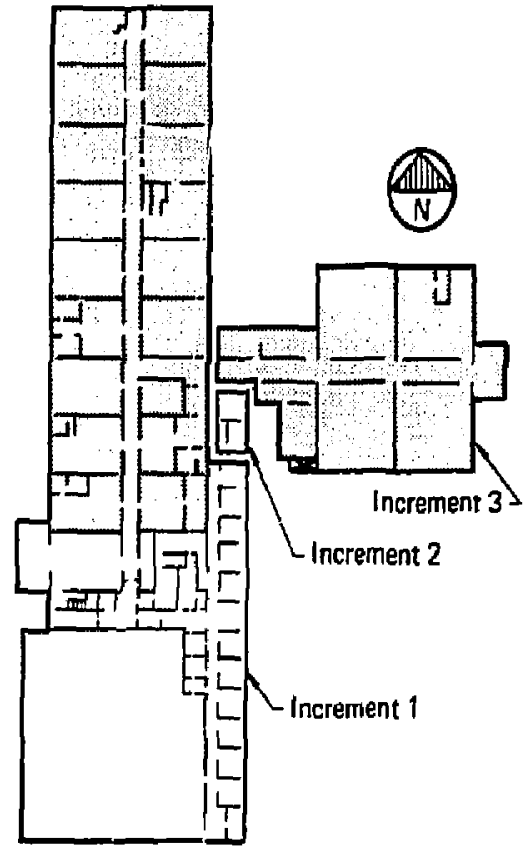

FiG. 11. Plan viev of Building 332 (ground Monr). The radioactive maturials areas are shaded.

Livermore sile. After a detailed raview of the 1972 study, LLNL's stalr in 1974 derived a vaiue or $0.8 \mathrm{~g}$ for the maximum horizontal acceleration of the ground due to earlhquake shaking. ${ }^{12}$ In light of this result, the LLNL staff is using this higher ground motion value to reevaluate all Laboratory facilities th'! house radioactive material at the Livermore site.

\section{Structural Studies and Upgrading}

Because of changing seisnis design srileria over the years, numerous structural studies and upgrading have been sompleted. In 1973, LLNL initiated a Laboratory-wide program to secure glovebaxes, equipment, and systems against shaking caused by earthquakes. Throughout the Laboratory, all such items that needed to be tied down were secured against a seismic loading equivales: to a 2.0-g horizontal acceleration. The Laboratory also did some confirmatory experiman. tal investigations into the integrity of gloveboxes. in these experiments, the glovebox, the filter, and the tools inside were subjected to a ground shoek level 
of $1.0 \mathrm{~g}$. Results from these tesis and other analyses by LLNL staff clearly indicate that gloveboxes like those in the Plutonium Facility will easily survive earthquake ground motions at the $1.0 \mathrm{~g}$ level withou damage.

Currently, LLNL is in the process of reevaluating facilitics that house appreciable amounts of radioactive material at the Livermore sile for a peak ground acceleration of $0.8 \mathrm{~g}$. Because of public attention centefed on the Plutonium Facility, this reevaluation concentrites on the asbuilt structures of Increments $I$ and 3 of Building 332. As part of this reevaluation. the LLNL staff has already assessed the intcgrity of this facility to the $0.8 \mathrm{~g}$ level. Our results show no significant structural problems are anticipated.

The recent controversy surrounding the las Positas fault zone to the snuth of 1he LLNL site, as mapped by the USGS in 1977, does not adversely affect the scismic analysis results and conclusion. The potential graund motion levels ilre not increased, and no evidence of a potentiai for surface offset neas the Plutonium Facility has been found.

In the interest of promoling a consensus concerning the seismic hazard at the Livermore site. LLNL has recently initated comprehensive field ir. vestigations. We are also initiating independent structural evaluations. Both studies will use outside privale industry feviewers.

\section{Independent Review of LLNL Plutonium Facility}

Because of incteased attention focused on the seismic safety of the Plutonium Facility following the Greenville earthquake sequence of January 1980, LLNL and the Department of Energy, San Francisco Operations Office (DOE SAN), have initiated an independent structural review. The objective of this review is to provide an independent assessment of the expected performance of the Building 332 strueture, systems, and components under earthquake-generated ground accelerations.

To help ensure the independence of the review process, the CSSC has agreed to review all phases of the nrocedure, from the sclection of the review team to the production of a final report and public meeting to present the findings of the panel.

As of this writing the selection of qualified independent reviewers is in the initial stuge. The primary criteria used to select potential reviewers were as follows:
- Must have broad experience in seismic structural dynamics and structural engineering.

- Must be familiar with the characteristics of Callfornia earthquakes.

- Must have experience in observation of structural damage caused by earthquakes.

- Must command peer recognition for their work in seismic engineering and public respet? based on their professional achievernents.

- Must be practicing in the field of seismic enginecring, preferably experienced in addressing the dynamic behavior of structures similar to Building 332, such that their familiarily with the issues is current and based on experience.

- Authority to use the title "Structural Engineer" is highly desirable. All reviewers under consideration have met the approval of the CSSC. A minimum of three revievers will make up the review team. At the conclusion of the review process, the review team will submit a joint draft linal report to the DOE SA N offict. This teport will then be made available to the CSSC and the public in preparation for a public discussion of the review: team findings.

After the public neceting. the revew team will address relevant public comments and any comments or observations offered by the $\operatorname{CSSC}$. A final report signed by all reviewers will be deith ered to the DOE.

\section{Conclusions}

The LLNL has completed extensite invesligittions and studies to cnsure the seisnic integrity of Building 332. This work has included both delining a design-basis earthquake for the site and making structural andilyses to evaluate the integrity of the built-in safeguard barriers-i.ce, the building, the gloveboxes, and the ventilizion system, Additionally, seudies are currently under way to further identify and characterize the seismology and geology of the Livermore Villey and to perform in independent, structural assessment of Building 3.32.

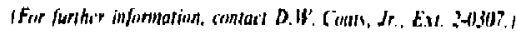




\section{Dyanimic Setanic Analysis \\ of Unit 4 of the El Centro Stenon Plant}

On October 15, 1979, at 4:16:55 p.m. (PDT) an earthquake shat had a Richter magnitude $M_{L}$ of 6.6 shook Calsornia's Impesial $V_{\text {alley. The epicenter }}$ was 'nt the Imperial Fauli, $5 \mathrm{~km}$ southeast of the EI Centro Stcam Plant. There was no loss of life in this sparsely populated agricultural area, but there was some property damage and extensive damage to irrigation facilities.

When the zarthquake occurred, only unils 3 and 4 of the four-unit nonnuclear El Centro Steam Plant were operating. The operating units tripped off line when station power was lost because of a short circuit. Units 3 and 4 were restored to service within $2 \mathrm{hr}$.

There was some minor damage to the facility: however, the two operating units safety shut down with no know'n malfunctions of electrical control and intstrumentacion equipment during or after the earthquake. 13,14
At the request of the U.S. Nuclear Regulatory Commission, the Lawrence Livermore National Laboratory (LLNL) performed a dynamic seismic analysis of Unit 4 of the El Centro Steam Plant to analytically estimate structural and equipment response. Built in 1968, the oil-fired Unit 4 was designed to resist a static lateral force equivalent to $20 \%$ of the dead and live load. The unit's structural and mechanical systems sustained only minor damage during the earthquake, which produced an estirnated $0.5 \mathrm{~g}$ peak horizontal ground acceleration $(0.66 \mathrm{~g}$ vertical) at the site. This earthquake level, it should be noted, js larger than almost all safe shutdown earthquakes $(0.2 \mathrm{~g})$ used for the design of nuclear power plants. Figure 12 is a photugraph of the plant.

\section{Structural Model}

The seismic response of the turbine building and its associated structures was determined using a normal mode, time-history methot of analysis with a linear elastic model composed of equivalent vertical beam members with masses lumped at foor

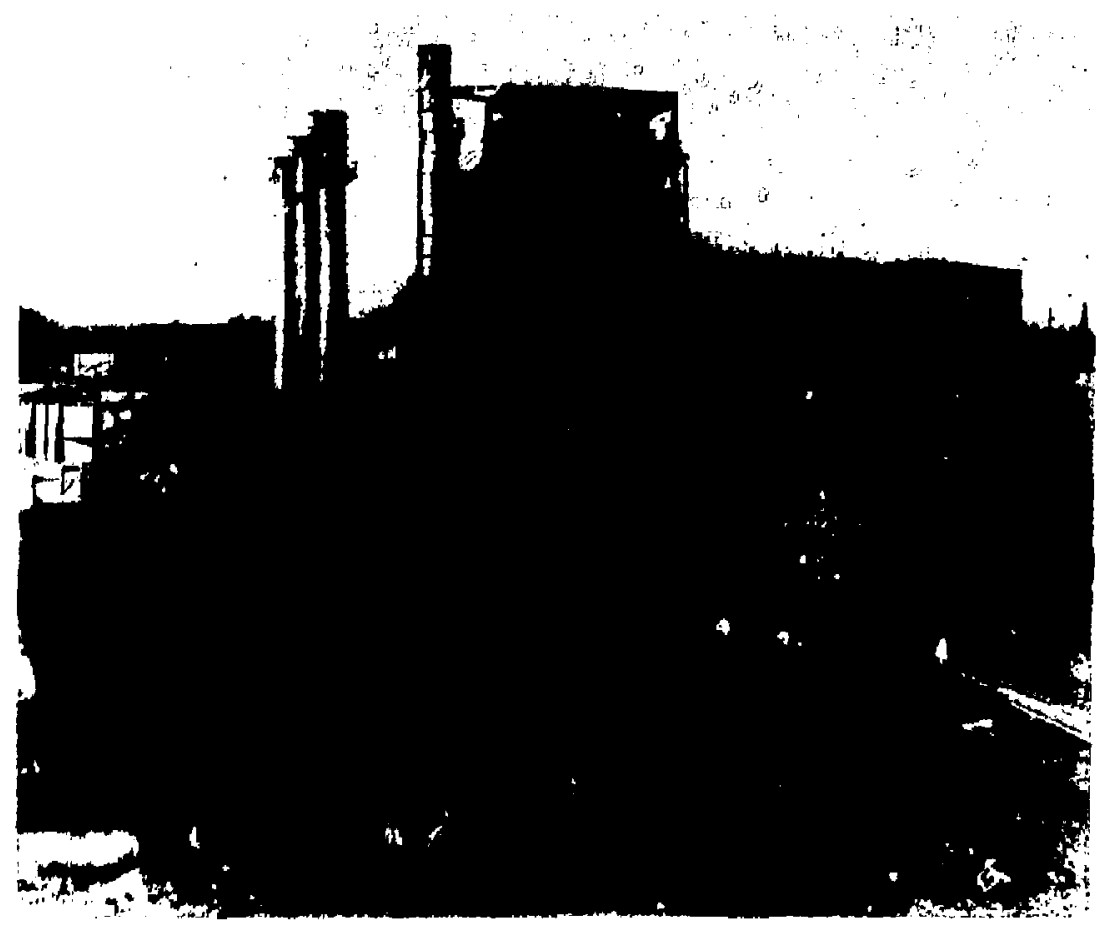

FJG. 12. Vtow toward the sonth side of Unit 1 of the El Centro Siean Plant. 


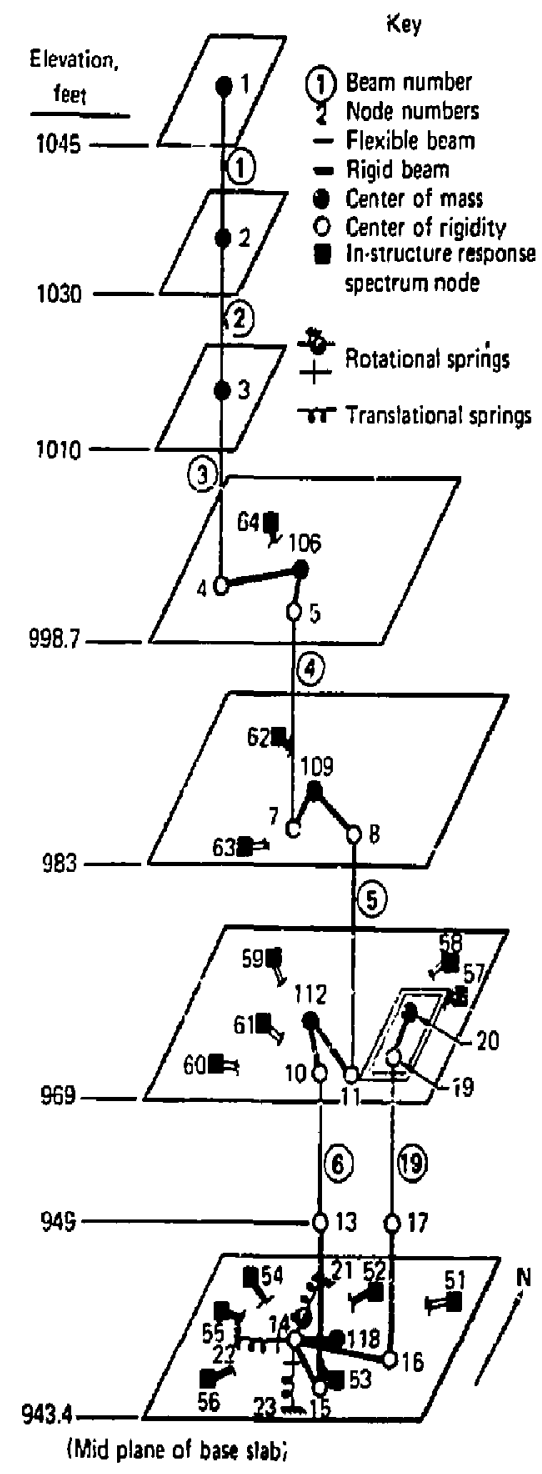

FIG. 13. Lumpet mas ad bean mold of Unit 4. Note the separale curtive pedestal beaw, ile transIntional and rotational soll apring on, and the wiflerear locations at cernain eteraliows of eewers of graviny an rigitity.

levcls. $\Lambda$ schemutic representution of the analysis model is stown in Fig. 13. Euch model mass point repressents the musss of the floor, boiler, and equipment at the respective level and a proportionate share of the mass of the walls and columns belween each level. All mussiscs are lumped al the respective floor levels of the structure. Each mass point has six degrees of freedom. The turhine building and the boiler support tower structural steel are interconnected and monolithically cast within concrete shear walls.

The material damping is aaken as $10 \%$ of critical damping for the concrete portions and $7 \%$ for the steel portions-the value recommended for highly stressed elements in NUREG/CR-0098.15 Note that the structure as a whole was not damaged; however, the use of these high damping values will lead tu a low estimate of the equipment acceleration and, by implication, its capacity.

\section{Soll-Structure Interaction}

To account for soil-structure interaction, the soil was treated as an elastic half-spare, and soil springs and damping wefe developed using the formulations in Ref. 16. The resulting six springsthree translational and three rotational-were attached to the center of rigidity at the midplane of the base slab.

In performing soil-structure inieractional analyses, the large calculated damping ratios for the suil are frequently of concern. This is especially true when using modal superposition methods with frenuency-jindeperident soil paraineters. As indicuted in Ref. 17, when the soil damping gets very high the respense upproaches that of the fixed-hase case.

For this analysis, the responses of the centers of gravity of the base mat and operatung floor were compared for the fixed-base case and the flexiblebase case, which uses composite modal damping incorporating the high damping ratios calculated.

Parameter studies were conducted using an arbisary $40 \%$ culoff on composite modal damping. Based on these studies. it was decided that the calculated iolues were reasonable except in the case of damping for the vertical direction where logic constraints of the software necessilaled a maximum input value of $100 \%$ damping.

\section{Seismic Inpul}

The time-history inpu! was obtuined from records of the October 15, 1979, Inperial Valley earthquake recorded at U.S. Geological Survey Station No. $5165 .^{18}$ Since the three components of the records were properly timed-phased, all three were simultaneously applied in the analysis. $A$ ground motion of $20 \mathrm{~s}$ with a 0.01 -s time step wass used for this anulysis. 


\section{Peak Acceleration and Response}

The maximum accelarations and response for the main equipment floors are shown in Table 1. Note thet the floor accelerations in the turbine building decrease as clevation increases. This behsvior results from the soil springs, which cause an increasc in the participation of higher modes compared to the fixed-base analysis.

The maximum predicted base shear values are relatively close to the design base shears determined Gum Ref. 19.

To estimate equipment responsc, in-structure response spectri nodes were selecied and corsidered to be rigidly atlached to the center of rigidity at each clevation in the model. Acceleration time histories and response spectra werc generaled al cach node. Then. for each direction, fundamental frequency and damping ratios vere estimated for cach of the 4) equipment items considered. The frequencies were either calculated, estimated by engineering judgment. or estimated by comparison to similas equipmens for which frequencies warc determined by analysis or test. Damping values werc estimated for elastic response. Equipment acceleration responses wers determined fiom the various instructure response spectra. In general, the equipnient acceleration responses varied from $0.5101 .8 \mathrm{~g}$ in the N-S direction. 0.4 in the E-W direction, and 0.4 to $1.55 \mathrm{~g}$ in the vertitill direction.

\section{Conclusions}

We concluded that the turbine building dynamic model with highly damped soil springs reasonably reflects the forces induced in the building during the earthquake. This conclusion is evidenced by the following:

- The low level of damage observed at the plant.

- The close relationship of the design to predicted base shears.

- The low displacement at the lurbine pedesial.

In druwing condusions ubout structural response, it is difficult to selate the static louding design criterion (a static tateral load equivalent to 20\% of the dead as well is the live load) to an earthquake loading characterized by a particular peak ground acceleration. However, for this particu'ar earthquake and structure the Iriaxial time hislory gives base shear values in close agrecment with the original design values.
TABLE I. Maximum structural gecelerations for main cquipment Tloors in units of $g$.

\begin{tabular}{|c|c|c|c|}
\hline \multirow[b]{2}{*}{ Hikenation (fi) } & \multicolumn{3}{|c|}{ Peak gramid astekration } \\
\hline & $0.49(N-5)$ & 0.35 & 0.66 (rentics) \\
\hline \multicolumn{4}{|l|}{ Turhine building } \\
\hline 998.7 & $0.5 !$ & 0.37 & 0.36 \\
\hline 983,0 & 0.51 & 0.38 & 0.37 \\
\hline 99.0 & 0.52 & 0.39 & 0.39 \\
\hline 949.0 & 0.55 & 0.40 & 0.40 \\
\hline \multicolumn{4}{|l|}{ Turtinc pedesial } \\
\hline 49,0 & 0.52 & 0,58 & (0.39 \\
\hline
\end{tabular}

The forces experienced by the plant equipment were on the order of 2 10 9 times greater than the $0,2 \mathrm{~g}$ specifted design load. This would seem $10 \mathrm{im}-$ ply a reserve sejsmic equipment capacity of about $200 \%$. However, it is difficult to verify this value without knowing the actual lateral load the equip. ment could wilhstand. Onc can only conclude that nu lear power filant equipment similar to that in Unit 4 and anchored as well should periorin equally well during a similar earthulake.

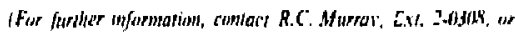

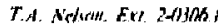

\section{Development of Probabilistic Seismic Failure Relationships of Nuclear Components for the SSMRP}

The Seismic Safety Margins Research Program (SSMRP) ${ }^{20}$ is an NRC-funded multiyear program direstcu toward estimating the conservatism in the ctorent NRC seismic safety requirements with the ultimute goal of develoning improved seismic requirements. As part of this program, calculations are being made of the risk of radioactive release from a typical commercial nuclear reactor in the event of earthquakes. These calculations require a knowledge of the probability of failure (fragility) of all safety-related components in the reactor system which would affect the outcone of the hypothesized accident scenarios.

Component railure is defined as cither lass of pressure boundary integrity or loss of operability. Failure (fragility) is characterized by a cumulative distribution function which describes the 
probability that failure has occurred given a value of loading, In the context of the SSMRP, loading may be locul spectral acceleration, local zero period acceleration, or internsl force fesultant such as moment, depending on the component and failure mode under consideration. Contrary to previous wosk. fragility is related to the appropriate local response, rather than being related directly to freefield perk acceleration.

The initial deternination of the necessary fragility functions has been completed. As a firsi step, all com?onents identified in the reactor fault tree analyses have been grouped into 37 guneric categories, ind fragility functions have been deterinined for each category. For example, all motoroperated valves located on piping with diameters between 2.5 and $8 \mathrm{in}$. are placed into a single generic category, and similarly all motor control centers have been placed into another generic category. All piping, lees, elbows, butt welds, and reducer sections have been placed into one generic eategory, and scaling factors (deperding on ize, malerial, and temperature) are utilized to relate the individual piping components to a single master fragility curve. The 37 generic categories are shown in Table 2.
Fragility functions for the 37 generic categories have been developed based on a combination of design analysis reports, experimental data, and an extensive expert opinion survey. In this survey, questionnaires were sent to more than 250 recognized specialists in the nuclear industry (representing nuclear power system vendors, utilities, testing laboratories, nuclear component manufacturers, architert-engineers, and consultanis) which resulted in 147 detailed responses covering (to varying degrees) vittually all the 37 generic categories. Responses to the questionnaires identified various failure modes as well as the failure percentiles as a function of loading.

A second source of information available was the generic design analyses performed by Wesinghouse and varjous component manufacturers for components used in the Zion plant. In these analyses, the component was assumed to be excited by a base acceleration torresponding to a prescribed dzsign spectrum. Then an analytical solution for the stresses or loads in the component was obtained. From these analytical solutions we obtained the acceleration at failure by extrapolating the stresses to our estimate of the ultimate strex capacity using a procedure duc 10 Newmark. ${ }^{21}$ In

TABLE 2. Gencric categories for components.

\begin{tabular}{|c|c|}
\hline - Refector core assembly & - Larze horizohtal ressels \\
\hline - Rezetor pressurc ressel & - Small-mediun ressels and heat exchangers \\
\hline - Pressurizer & - Large vertival centrifugal pumps with molor drive \\
\hline - Steangenerator & - I arge vertical pumps \\
\hline - Reactor coolant punp & - Motor-driven compressors \\
\hline - Pipiar & - Lirge motoraperated valies \\
\hline - Large rertical storage vessels with formed heeds & - IArge relief and check valies \\
\hline - Large vattical storage tank- flat botton & - Small ralies \\
\hline
\end{tabular}

Electrical

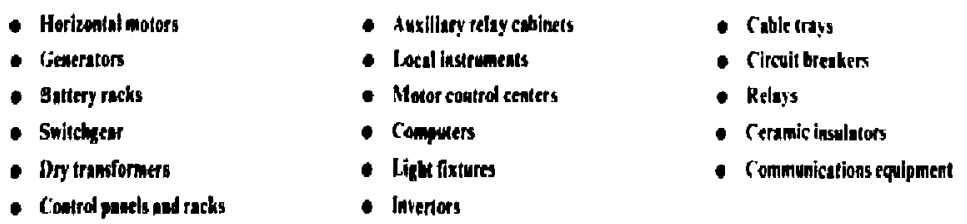

\section{Mlscettawrows}

- Ar handing units

- Duct nork

- Instrumetert racks

- Hydratilic sumibers 
this procedure, the acceleration at failure is determined from the relation

$$
A_{F}=A_{D} F_{S} F_{\mu}
$$

where $A_{D}$ is design peak acceleration, $F_{S}$ is the factor accounting for ultimate load capacity, and $F_{\mu}$ is the factor accounting for the inclastic energy absorption capability. Thus $\mathrm{F}_{\mathrm{g}}$ scales up the design acceleration to the failure acceleration, assuming all loads (or stresses) are calculated by a linear elastic analysis, since the peak load (or stress) is proportional to peak acceleration.

Before failure occurs, however, a significant amount of inelastic deformation (and hence energy ahsorption) takes place. In this inelastic response range, the stress increases much more slowly than the peak acceleration. The actual acceleration at failure is much tigher than that predicted by a linear analysis. This additional acceleration capacity is accounted for by the ductility factor $\mathrm{F}_{\boldsymbol{\mu}}$. Complete details for these calculations are in Ref. 22.

The experimeital data utilized in developing fraglitity curves wete obtained from the resuits of component manufacturers" qualification tests, independent testing laboratory failure data and data obtained from the U.S. Corps of Engineers S.,FEGLiARDS Subsystem Hardness Assurance Program. These data were critically examined for applicability and then statistically combined with the expert opinion survey data to produce the linal fragility curves for the 37 gencric component categories.

To illustrate the results of the fragility development, a number of typical log-normal fragility relations are presented in Table 3. For each eategory, the value of the median response at failure $M$ and a value of $\beta$, the standard deviation of the natural logarithm, is given. The probability of the response A exceeding the strength is then given by

$$
\mathbf{P}_{\text {Fijlure }}=\phi\left[\frac{\ln (A / M)}{\beta}\right] \text {. }
$$

where $\phi[]$ is the standard normal cumulative distribution function available in any statistics text.

(For further infonmation. contacl M.P. Bohn, Ext. 3-0856, ar L.E. Cover. Ext. 2-1306.1

\section{Preliminary Results of Thermal Igniter Experiments in $\mathrm{H}_{2}$-Air-Steam Environments}

During the Tlirec Mile Island nuclear accidtnt of 1979, gaseous hydrogen was produced in the reactor vessel from the reaction of steam with the exposed zirconium fuel-rod cladding. This hydrogen eventually escuped through an open reliel

\begin{tabular}{|c|c|c|c|c|}
\hline Cittivery & Parterter & $\mathbf{M}_{\mathbf{A}}$ & $\beta_{A}$ & Lowest failure mode \\
\hline PWR resctor renet & SA at 4 fit act Sx & 3.72 & 0.18 & Nozde smport failure \\
\hline Prewariver & SA 48 He and 56 & 200 & 0.39 & Anchor bolt failure, stron faciere \\
\hline Sirso generator & SA at $8 \mathrm{ht} \cos 5 \%$ & 4.00 & 0.27 & Support leg buckliag ned raikme \\
\hline Coolaw prop & $S A$ t 4 he ad $5 \%$ & 264 & 0.34 & Fature of contuction to sorport leg \\
\hline Diesel genesalor & A & 0.65 & 0.33 & $\begin{array}{l}\text { Control system malfuaction, oilieg } \\
\text { sygrem frilure }\end{array}$ \\
\hline Lege molor-gerated valve & $\boldsymbol{A}$ & 6.30 & 0.40 & Electrical failure, actustor bielies \\
\hline 4his pixe, cution sed & $\mathbf{M}$ & 24 & 0.39 & Butt weld railure at $70^{\circ} \mathrm{F}$ \\
\hline 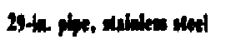 & $M$ & 203.3 & 0.38 & Strwight wipe (2S-ite thisk) at 600 ${ }^{\circ} \mathrm{F}$ \\
\hline Moler cannel thetr & $A$ & 1.70 & 0.93 & Cincuit breaker trips \\
\hline Calk inays & SA \& 4 Hix and $5 \%$ & 2.33 & 0.59 & Wed and nepport falimes \\
\hline Conted pamen and rects & $\mathrm{SA}$ : $12 \mathrm{~Hz}=\mathrm{a}$ 58 & 3,6 & 0.83 & Instrument frilwe \\
\hline Cerancic inclaters & $\mathbf{A}$ & 0.17 & 0.39 & Breaknge \\
\hline
\end{tabular}

TABLE. 3. Selected Iragility relations.

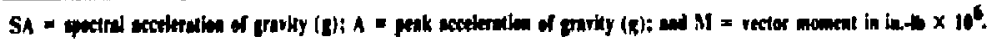


valve into the containment building. At some point the hydrogen-air-stentm mixture was ignited, producing an estimated 28 psi pressure spike.

Postaccident calculations indicate that the con. ainment building atmosphere included more hydrogen than previously expected during such an accident. This has caused the industry (and the Nuclear Regulatory Commission) to reevaluate the potential risk from hydrogen burns inside containment buildings, which are generally not designed to withstand an overpressure much larger than that experienced at TMI.

In an effort to reduce risks from such situations, the Tennessee Valley Authority (TVA) has proposed and installed an Interim Distributed Ignition System (IDIS) in the Sequoyah Nuclear Plant, which in late 1980 received its low power license. The IDIS consists of conventional diesel engine glow plugs distributed throughout the contajnment. These plugs are to be manually energized simultaneously, once hydrogren has been detected by the plant monitoring system during an accident. Their purpose is :o initiate combustion as soon as the mixture will burn (presusiably at low hydrogen concentrations), preventing the accumulation of a detonable atmosphere.
In July 1980 the NRC Office of Nuclear Reactor Regulation requested that Lawrence Livernoze National Laboratory conduct a short-term test program to evaluate the functionability of these particular glow plugs in environments containing known concentrations of hydrogen, air, and steam. Initidled August 1, 1980, the experiment was designcd, constructed, and tested by Noventiber 10 , 1980. Detuils are reported in Ref. 23.

The objective of the LLNL program was specifically to assess the functionability, or capability to ignite the mixture, of the glow plugs proposed by the TVA. Mixtures to be studied ranged from 6 to $16 \%$ dry hydrogen. and 30 and $40 \%$ steam fractions, each with 8,10 . and $12 \%$ hydrogen.

Figure 14 is a schematic of the igniter lest fasility. The burns were contained in a 20-in.diam by 6C-in.-long pressure vessel with a working pressure of $200 \mathrm{psi}$. The vessel was modified by the iddition of two 8-in.-i.d. ports and one 4-in. porl, as wull as threuded penetritions for plismbing and instrumient connections. Salurated steam was sunplied by a 300-1h/hr hoiler at approximately $75 \mathrm{psi}$. Mixing of the contenıs was accumplished with an air-powered fan placed at one end of the chamber.

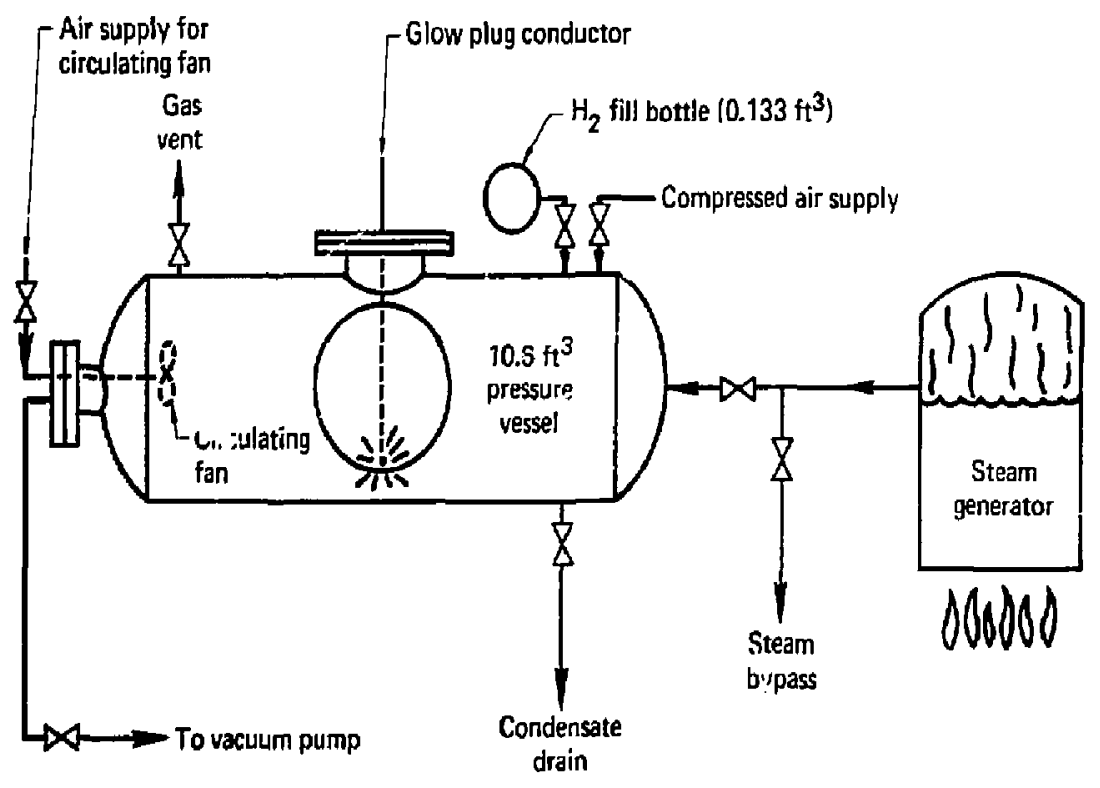

FIS. 14. H/ igniter test schematic. 
During this test series the glow plug was positioned $3 \mathrm{in}$. above the bottom of the vessel powered by a 14.4 VAC source (13C W). Figure is shows the test vessel and instrumentation.

All testing was conducted remotely al the LLNL high explosives test facility, Site 300.

\section{Insirumentation}

Primary data for the igniter tests included temperature and pressure measurements, and g*s concentration analysis.

Tesi vessel temperature measurements were made with Chromel-Constantan (type E) thermocouples, indicating temperatures of the mixture inside the vessel, the vessel outer wall, and the ambient air at the facility. Pressure indications were provided by strain gage pressure transducers. Clow plug aynamic performa cee data inciuded temperature, voltage, and current measurements.

Pressure measurements and most of the temperatures were recorded on high-speed frequencymodulated magnetic tape, then digitized and transferred to compuler tape for filtering, reduction, and plotting on the LLNL CDC 7600 computers.

Gas analysis was accomplished by a 15 location sampling system and mass spectrometric analysis. The $75-\mathrm{cm}^{3}$ sample battles werc evacuated before each test and $m^{\prime}$ unted on the appropriate stations. One boule was opened for $5 \mathrm{~s}$ before each glow plug activation, and another after a burn had been indicated. The mixture in the vessel was circulated before each sampling.

\section{Test Resulls}

Peak pressure as a function of hydrogen concentration is plotted in Fig. 16. Also shown is a dashed line representing the calculated maximum adiabatic pressure rises from dry hydrogen-a ir burns, calculated with the CECS code. Steam tests exhibil noticeably lower pressures for given hydrogen concentrations than dry tests. This is lo be expected since steam acts as a diluent.

Completeness of combustion appears in Fig. 17. These data are consistent with results obtained in other test programs in that burn completion approaches $100 \%$ as the hydrogen concentration nearts 9\%o for dry mixtures. The steam tests again evidenced less complete burns than dry concentrations.

\section{Coschusions}

This experinental program addressed thermal igniter functionability in a variety of hydrogen-airsteam environments to better undurtand the performance characteristies of an Interim Distributed Ignition System during a postulated Loss of Coolant Accident. The following conclusions can be drawn from the results:

- Thermal igniters are capable of combusting low concentrations of hydrogen in dry air, even below the $10 \% \mathrm{H}_{2}$. (The mixture should be combusted in this region to prevent potentially dangerous pressure pulses arising from higher concentration burns,) Although the low $\mathrm{H}_{2}$ concentrations do not produce complete combustion, the range hel ween 8 and $9 \%$ appears to be tie transition to complete burn conditions. The iransition to complete buen conditions with steam has not been clearly defined in these tests.

- Sieam acts as a diluent in all cases, suppressing both the magnitude of the pressure rise and the completeness of burn.

- The glow plug performance did not appear to degrade throughout the test series.

- Circulation of the mixture enhances combustion, most apparently at lower $\mathrm{H}_{2}$ concentrations.

The author expresses appreciation for support by the following individuals throughout the course of the program: Barry Bowman, Bill Comfort, and Dick Murtin for initial experimental design and subsequent technical assistance; Del Eckels, Bill Shay, and John Holm for mechanical and instrumentation design. fabrication, and operation: Rex Blocker for program coordination; Bob Kaster For Site 300 bunker operation; and Charley Tinkler, U.S. NRC technical monitor.

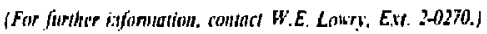

\section{Lond Combination Program to Aid Nuclear Power Plant Design}

Nuclear power plant structures, systems, and components are required by law to be designed to withstand the appropriate combination of the effects due to normal operation, natural phenomena, and postulated accidents.

The postulated accident loads, and loads caused by natural phenomena, are random events. 


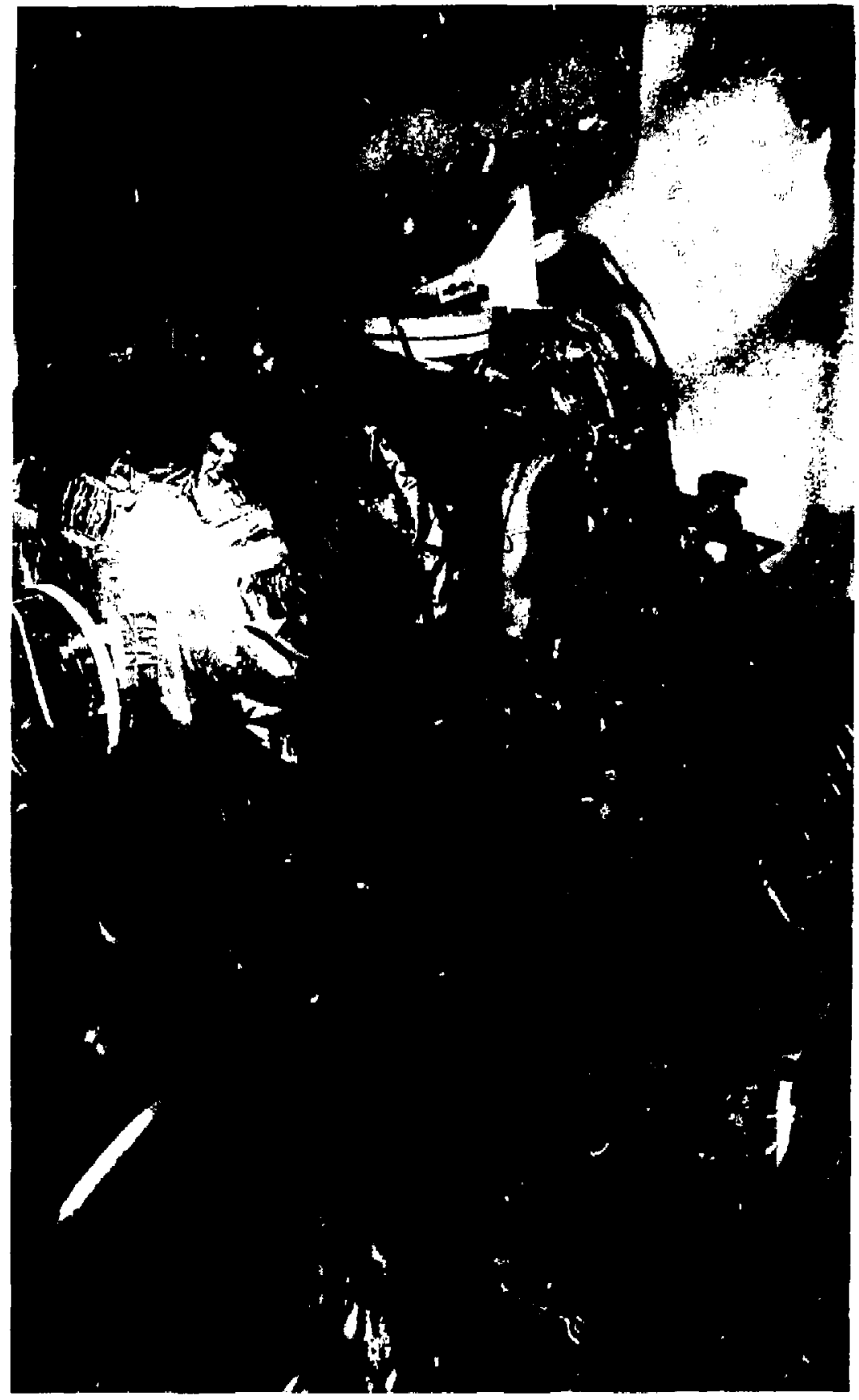

FIG. 15. Pressure ressel with instrumentation. 


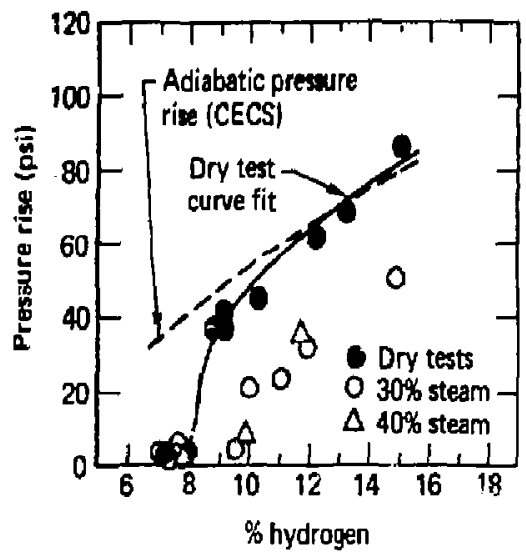

FIC. 16. Pressure rise as a function of $\mathrm{H}_{2}$ concentration.

Amplitude, duration, freguency, time of occurrence, and cime-phase relationship are random and stochastic in nature. Without a systematic pr ibability assessment, it is difficult to come up with a rationale for appropriately combining events.

Current nuslear power plant design criteria have therefore been based on judgment toward conservatism, becalise no comprehensive probabilistic study and unified piilosophy exists on which to base better-founded vecisions. Consequently. safety margins between various systems and from plant 10 plant vary widely. Trying to follow the inconsistent and fragmented load combination requirements is frustrating to the nucleas industry.

The Load Combination Program, a multimillion dollar, long-ierm research program undertaken by the Lawrence Livernore National Laboralory, is a major effort to resolve these difficule and important issues. The program is funded by the U.S. Nuclear Regulatory Commission (NRC).

Current planning is that the program will continue through 1985. The long-term overall objectives are as follows:

- Define each individual load by these meàns:

(a) Develop a methodology to estimiate the reliubility of typical piping systems, both inside and outside the containment structure, and provide the NRC witb a sound izchnical basis for defining criterial for pasiuliting pipe bruaks.

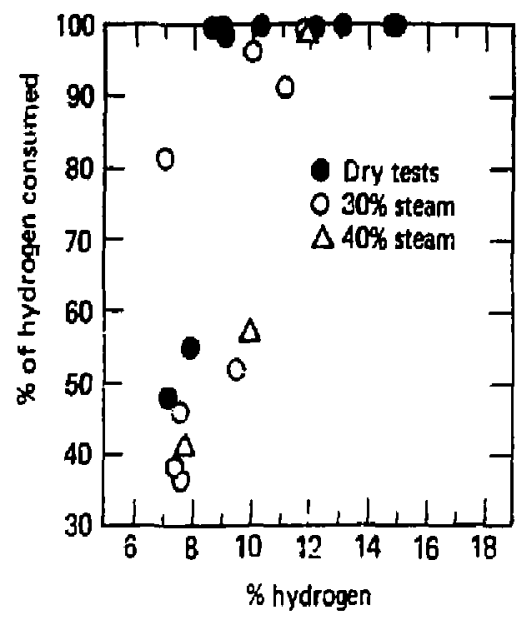

FIG. 17. Burn complettinass as a function of $\mathrm{H}_{2}$ cencentration.

(h) Assist the NRC in deflning individual dỵamic load magnitudes and etert occurrence ralles.

(c) Develop a methodology to estimate the dependenc; betwien events, for cximple, the probability of a loss-of-coolant accident (LOCA) or Hilter hammer insuced by earthquakes.

- Divelop a methodology lo establish load combination critcria for nuclear potier plant design. This mell.udology should be zapable of addressing basic issues wilh regard to which loads need to he combined. how they arc to be comined, and what service level is applicable under the Boiler and Pressure Vessel Code of the American Society of Mechunical Engineers (ASME).

The first phase of the Load Combination Program started March 1979 and was completed at the end of the summer of 1980. The following objectives were alddressed relating to two major issue.:

- Estimiste the probability of a lisge LOCA induced by curlinquakes for a selected pressurized water reactor (PWR) plant and devclop a prohabilistic franture mechanics model that can be used to estimate piping reliability in general.

- Detclop a methodology for combining generic dynamic loads for nuclear power plant design.

The first objective recuires (lie develdamen: of a deterraisistic fracture mechanics model for faligue 
track growth. This model. incorporated wits stochastic inputs of initial crack size distribution. maleri:al propurries, stress historits, and leak detction probathility, is used to calculate the probability of pipe le:k subjected to the various loading condi. tions, including seismic. A schemiatic representation of the various steps in the analysis shows their in-

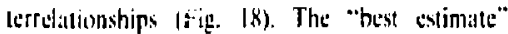
model and approsach were used in the computation. The prohstbility results together with their uncertasnties are used to determine whether low probability wents such als a larece LOCA and Safe Shutdomn Fiarlhyuake (SSE) should hat combined for the devegn of nucktar structures and componemis. Results Indicalte that the probability of at double-ented gullontine sreak, exther with or withoul : all sirthyuake. is ser! small fon the order if 10 - The probathiling of a leak wa found to be

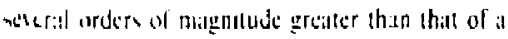
complete pipe ruptere. The results of our study have

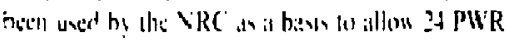

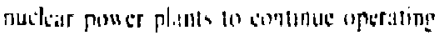

The derelopment of a methodolog! for com-

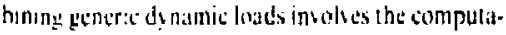
ton of sumpenent relisthility to derine the appropriale loud onmbination reguirtments for

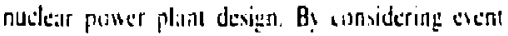
prothahitity. the nature of these seents. siruscural propertise, response charicteristices, atto other randoun phenomenit. this methodolng! will achieve grestler conssitente in compunem design than wan he achieved with turrent prastice. With this methudolog?, the SRC cill wialuate compenen! retiabslit! impled b! surrem design. The inethodology can also he uned to conly lare the compollent reloil tylity inplied by the use of the sydare roth of the win of the square (SRSS) and ahsolule sum (ABSS) protlern.

Tuo piping desizns were used for illusiratson. The firs enample deals with an Ensential Service Water (ESW) line in a PUR piam subjected to x'ssmic and hydraulis transicent loudsa in addition to self-ncight, thermal eapansion, and interial prosure. The second eximple deals with a Stean Redief Value (SRV' lane from) a sy picall boiling w ater Fat ir (BWR) Mark II plam subjested to normal.

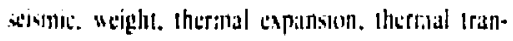
sient. SRV huildng secponse. SRV stean hanomer. SRV Jicharget, SRY Jrilg, condensitlion ascillition. and chugenge losding wonditions. The proper lovad conmbination expations were derestoped for the
Lwo systems based on comperent reli tbility criteria. A comparisun between SRSS and ABS response combinations was also undertaken. The appropriate service level associated with each load combination case was diacussed.

IFon futher informutian, andact C.K. Chou, Evt. 2-BS/5,

\section{Spill Test Facility for Liqueried Gaseous Fuels}

Tae Lawrence Livermore National Lahoratory. under the direction of he Department of Energy's Environmental and Saletv Enginer ing Division, is participating in the Liquefico Gaseous Futels (LGF) Salert and Environmental Control Asscessment Prugram. The DOE goal is to provide safety infurmation to industry, regulatory agencies, and the public for the selection of sites for LGF terminals and storage facilitics and for the design and operation of thest facitities, as uell as iransport facilites sucls as hipn. rail cars, and trucks.

The priacipal obj ctive of the LGF Spill Test F.evilit? at the Newada Test Site is to experimentully verifi predictive compuler models. Verifying the accurac! of the computer models sequises al spill test facility cupable of handling cxperiments of sufFicient sire and operational variabilsty to lest the nowdels over a signilicant range of phenomena. Once verified. the models can then be used to jecurately prediet accidental spill effects so 10300 times birger than the verify ing expermmems.

The new est factilits w ill be ahle io apill 10 to $500 \mathrm{~m}^{3}$ of $\mathrm{LNG}$..m. i illy. and LPG. $\mathrm{LNH}_{3}$, and $\mathrm{LH}_{2}$ later. The expersmests planned for the new facility

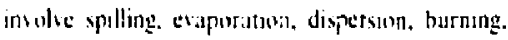

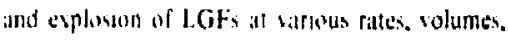
atmospherec conditoons, and espermential arrangto ments.

The spill facilis desegn concept (Figg. 19) con-

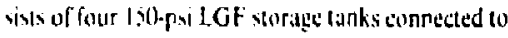

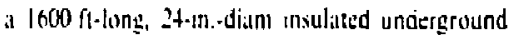
vill pipe which leads 10 a $10002-1$-diam spill pond. The center of the poind will he $25-f$ deep. The LGF will be forced. by 150-psi nitrouect or belium gils stored in 120 2500-psi, 67-m pressure vessels. To drive out the LGF remanning in the spill pipe after the storage tanhs ar: empted, a cringenke pipeline nig uil! be forced through the spill pipt h! injerting I:50-psi mitrogen gils hethind the piẹ. 


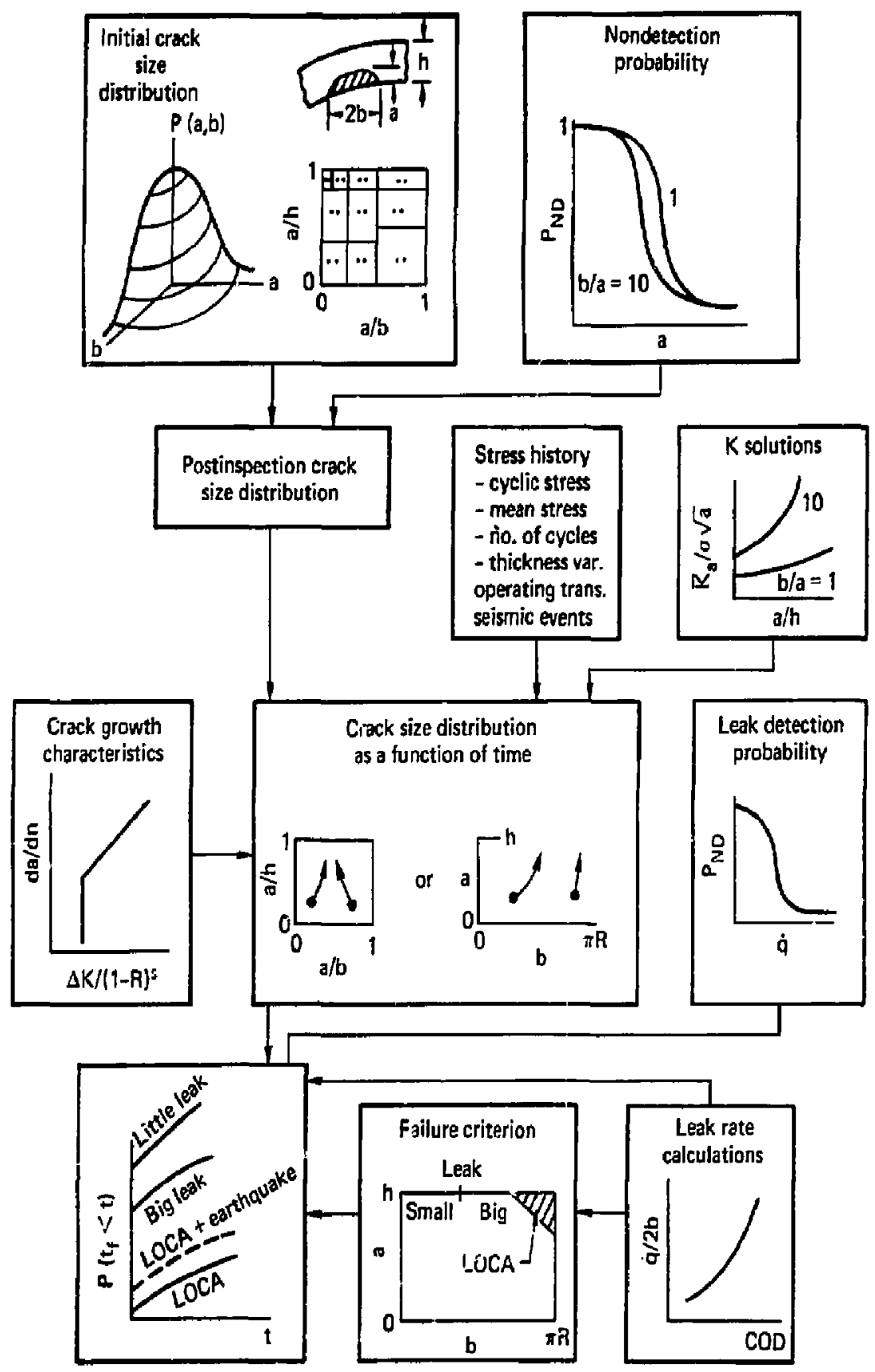

FIC, 18. Sctematic representation of the various steps in the analysis show, their interrelationships. 

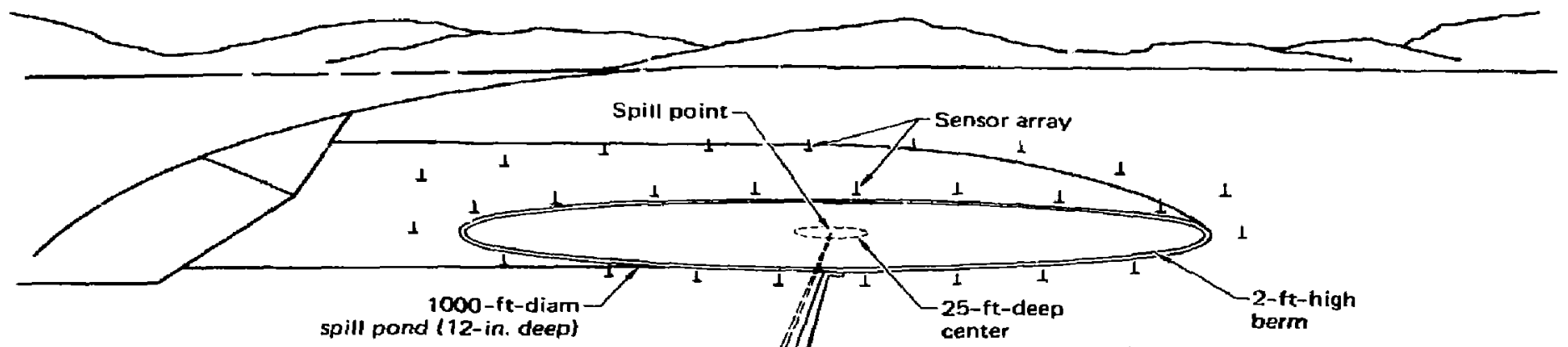
spill pond (12-in. deep)

24-in.-diam by $1600 \mathrm{ft}$ buried spill pipe

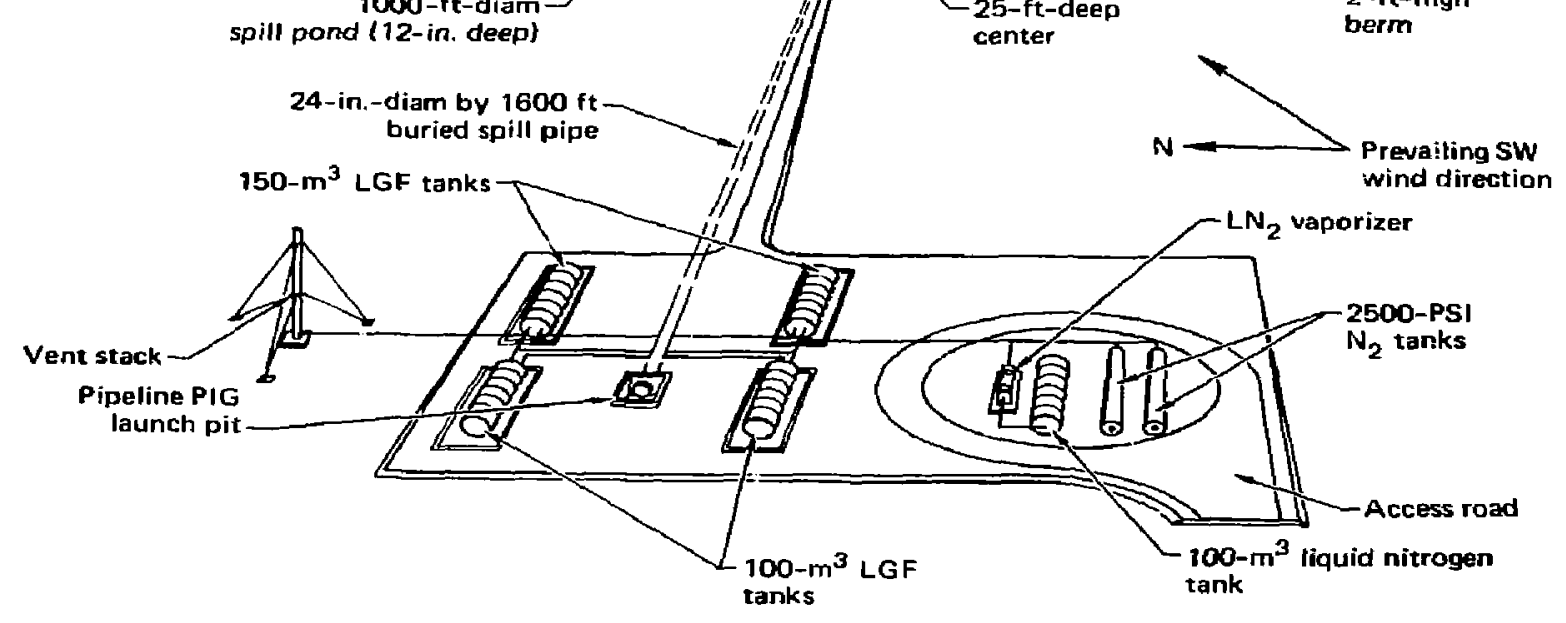

F1C. 19. Arrangument of test facility for a $500-m^{3}$ LGF spill. 
To conduct spills on dry soil, the shallow periphery of the spil pond will be drained and a 100-fi-long extension will be installed on the end of the spill pipe, extending it to the peripheral area. Various nozzles and splash plates will be installed on the end of the pipe to vary spill velocity and direction on or below the water. An array of $\mathrm{ex}$. perimertil measusement sensors will be placed upwind and downwind from the spill point. The facility will be controlled and monitored by a control trailer located approximately $5 \mathrm{mi}$ south of the tankage area.

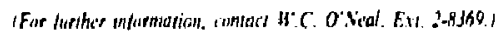

1. A. Blike, V. Kutpenko, E. McCaulat. C. Walter. A Concepl for Underground Sitimg of . Vuetear Power Reacturs, Lawrence Livermore National Laboralor!, Livermore, CA. Repl. UCRL-51408 (1973).

2. Barry R. Bowman, Hugh E. Watling. and Edward W. MeCauley. A Concept of Underground Nuclear Power Plan Siting for Retaining Pesi Accidem Atmosphoreses, Liw rence Livermore National Luboralory, Livermorts. CA. Rept. UCRL-84191 (1981).

3. E. Ausi. "Druckabbauversuche auf dem PSSVersuchsstand der GKSS-Basispropranı uber Mchrrohr-Versuche fur Druckathilusissteme von Landanlangen." GKSS Furschungs/Lntruni Gutsthachı, Rept. GKSS 78/I/15. May 1978.

4. J. Vollbrand,. "Messsystem fur das DASMehrrohsversuchsprogramm," GKSS Forschungszentrum Geesthacht, Rept. 7303 AR B 57, November 1978.

5. D. L. Bernreuter and F. J. Tokar/. Dersign Bassis Earhlquakes for the Lanrence Lirermure Laboralory Site. Lawrence Livermorc National Lahoratory, Reph. UCRL-51193 (1972).

6. John A. Blume \& Associales, Engineurs, Sun Francisco, California, Pluromium Lahurasur!. Lawronce Livermore Lahoralor!: Goolugis. Scismologic. and Foundarion Investigations. prepared for Maher and Mariens-Archilects, San Francisco. California. Novtmber 1971.

7. John A. Blume \& Associalte, Enginetrs. Investigation of Fathing at the Lastence Liver- more Lahoratory, Laurence Livermore National Lathoritury, Rept. UCRL-13568 (1972).

8. U.S. Department of Energy. Washinglon, D.C.. Drafi Environmental Impoct Statement. Livermore Sirs. Livernore, California. DOE/EIS-0028-D. September 1978.

9. Safety Ar.lysis Report for Btilding 332. L.aurence Livermore National Laboratory. Rept. UCRL-51590, Draft (1974).

10. Final Safety Amalysis Report for Building 332, Increnrent III, Lawrence Livermore National Laboratory, Rept. UCID-17565 (1977).

11. L. H. Wight. $A$ Geological and Seismological Investigation of the Lasirence Livermore Labaralory Sire, Lawrence Livermore National Laboratory. Livermore, Culifornia, Rept. UCRL-51592 (1974): also appears as Appendix $2 A$ of DEIS (1978).

12. F. Tokarz and G. Shaw. Seismic Sojety of the LLL Plutonium Facility (Building 332). Lawrence Livermore National Laboralory. Livermore. California, Rept. UCRL-52786 (1980).

13. R. C. Murray, T. A. Nelson, R. D. Campbeli, J. A. Young, H. A. Levin, J. A. Martore, and L. Reiter. Equipment Response at the El Centro Steam Plan During the Oclober $15.1979 \mathrm{Im}$. perial Valley Earthquake. U.S. Nuclear Regulatory Commission, NUREG/CR-I665 (1980).

14. O. W. Steinhardt. "Eurrthqualke Ellects ai El Contro Pouser Plam,." in Recommaissance Repurt Imperial Coumtr. Califurnie, Fastlquake. Ocloher 15, 1979. D. I. Leds. Ed.. Earthquake Engineering Research Insitute. Burkeles. CA (1980).

15. N. M. New mark and W. J. Hall. Dertelupme'm of Criseria for Seismic Re'vie's of Seltected Nucterar Pouter Plans. L'S. Nuclear Regulatury Commission. NUREG;CR-0098 (1978).

16. Hall, Richart, Woods, Vibrations of Soils and Foundorions (Prentice-Hall, Jnc. 1970).

17. NCT Enginecring, Inc., The Role al Radiation Damping in the Imperdance Fintition A sprousth to Soil-Siructure Imerastion Audysis, Laurence Livermore Nationil Laburators. Livermore, CA. Repl, UCRL-15233 (1980).

18. R. L. Porcella and R. B. Mathiesen, Preliminary Summary of the C.S.S. Grolugical 
Suney Sirong-Motion Records from the Or. tober 15. 1979, Imperial Valle! Earthquake. U.S. Geological Survey, Menlo Park, Calif., Open-file Report 79-1654 (1979).

19. The Fluor Corporation, Limiled, Engineering* Design and Construction Completion Reporl for the Imperial Irrigation Districl El Centro Steam Plant $80 \mathrm{MW}$ Unit No. 4, Los Angeles, Calif. (1968).

20. P. D. Smith et al., Seismic Safety Margins Research Program-Phose I Final Report-Overview, Lawrence Livermore Nalional Laboratory, Livermore, CA, Repi. UCRL-5302I, vol. I, and NUREG/CR-2015, val. 1.
21. N. M. Newmark and C. A. Cornell, "On the Seismic Reliability of Nuclear Power Plants," Am. Nuc. Sac. Topical Meeting of Prababilistic Reacsor Safety. Newport Beach, Calif., May 1978.

22. R. D. Camphell et al., Seismic Safesy Margins Research Program-Subsystem Fragility, Structural Mechanics Associates Rept. SMA 12205.06.01, December 1980.

23. William Lowry, Preliminary Resulis of Ther. mal Igniser Experiments in $\mathrm{H}_{2}$-Air-Sleam Environments. Lawrence Livermore National Labcratory, Livermore, CA, Rept. UCRL84167, Rev. 1 (1981). 


\section{NUCLEAR EXPLOSIVES ENGINEERING DIVISION}

Our major mission is to support the Laboratory's Nuclear Explosives Progeram (NEP) in developing operational nuclear weanons systems for the U.S. stockpile. We also support the Nonnuclear Ordnance Program, Organic Mattrials Division. and $H$ (Physics) Division. We perform studies and develop hardware for Y.Program, Nuclear Regulatory Commission (NRC), Z-Division, and the Defense Nuclear Aguncy (DNA).

NEED's project leums are dedicated to specific engineering areas: conceptual nuelear design, stritegic systems, development and production/liaison for nuclear weapons systems, advanced fission and fusion systems, hyurodiagnostics development. and maintentance and upgrade of the Sitc 300 test lacilitics. Our Applicd Mcchanics Group supports Laboratory programs with calculational expertise in solid mechanics and transport phenomenia, and the Auxiliary Systems. Group supports Laboratory programs with expertise in high-pressure gas technology.

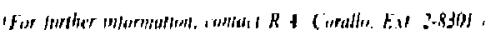

\section{Livermore Flame Experiment Simulates LNG Spill and lgnition}

As energy costs and demand continue (u) rise. the Lnited Slates is faced with prospects of increasing imports of liquetred natural gas (LNG). In the event of an adceident inwlving an LNG tinker. laste quantitics of spilled liquid would saporize and thus form a large potentially explosive cloud. Hou this cloud would reacl and hurn when ignited by a stritable ignition source is the subject of a multig car. mulımillion doiliar program the Labosatory is conducting for the Department of Entrge. The Laboratory is involved becaluse of its computational cun:ibility to develop very large computer models of phystical and chenjical processes, ind its experitnce with reactions insolving large releasts of entergy.

In addition to field tests, which involved spills of four or five cubic meters of LNG at China Like, Cullif., smill-scale laboratory tests were conducted by igniting gaseous mixlures of propane and air to provide statistical modeling data. Our test fixture was a flatre bed (Fig. I) 90 by 30 by $15 \mathrm{~cm}$, open at the top and at one end to simulate an unconfined

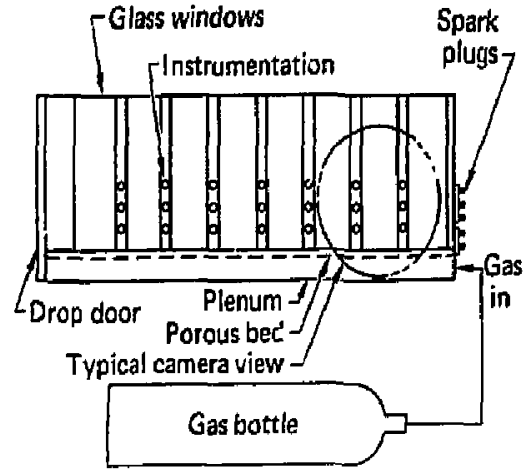

FIC. 1. A schematic representation of the flame bed experiment.

geomelry. The bottom of the flame bed served as a full-sength plenum separated from the bed proper by a layer of porous material. The side walls consisted of optical-quality glass pancis separated by vertical aluminum bars which contained transducers and ion gaps.

Photographing the fame front wis done with at rolating drum, high-speed framing canucra using light from an expanded argon-ion laser and schlieren mirrors. In operation, al premixed gas-air mixture stored in a gas hottle was jntroduced into the plenum and allowed to diffuse through the porous bed into the flame bed. Being beavier than ajr, most of the gas mixture stuyed in the flame bed as it filled, aided by a drop door at the opposite end which was releused just as the shot was firtd. The ignition source was a capucitor bank across automotive spark plugs mounted on the end plate. We also had large glon pluos a a ajilable to simulate othet types of ignition sourets.

Turhulent eddits disturb the Barme verface artia, sausing a grtilter ratc of tonergy recleast. In an actuil spill, turhulence could come from il number

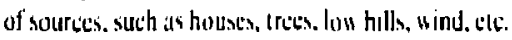
We wert able to succicostully nodel thin effect by using obstactes of different heights placed on the poroun hid.

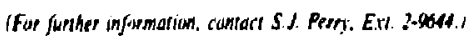




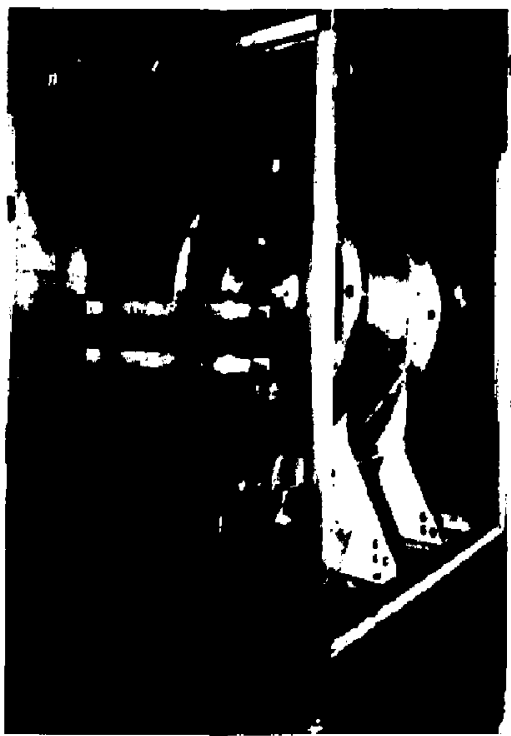

FIG. 2. The x-ray water generator.

\section{New X-Ray Water Bhumlein System Measures Plama Dewsity More Acemately}

A new water Blumlein $x$-ray generator has been designed and fabricated for $x$-ray diffaction and radiography experiments. The Blumlein (capacitive energy storage elements that are capable of producing a flat-topped output pulse) is currently being used on the Shiva/Nova Plasma Shutter experiment to measure the areal density of a plasma. This new system will have increased operating voltage, improved reliability, and a simpler design compared to the conventional polyethylene Blumlein.

The water Blumlein, as shown in Fig. 2, has a negative de voltage applied to one side of a $0.3-\mu \mathrm{F}$ low-inductance capacitor isolated from ground by a spark gap switcn. The other side of the capacitor is connected to the inner conductor of the water line. A remote $x$-ray tube is connected to the outpul end of the Blumlein, with the inner conductor connected to the anode of the $x$-ray tube and the outer conductor to the cathode. Deionized water separates the inner and outer conductors.

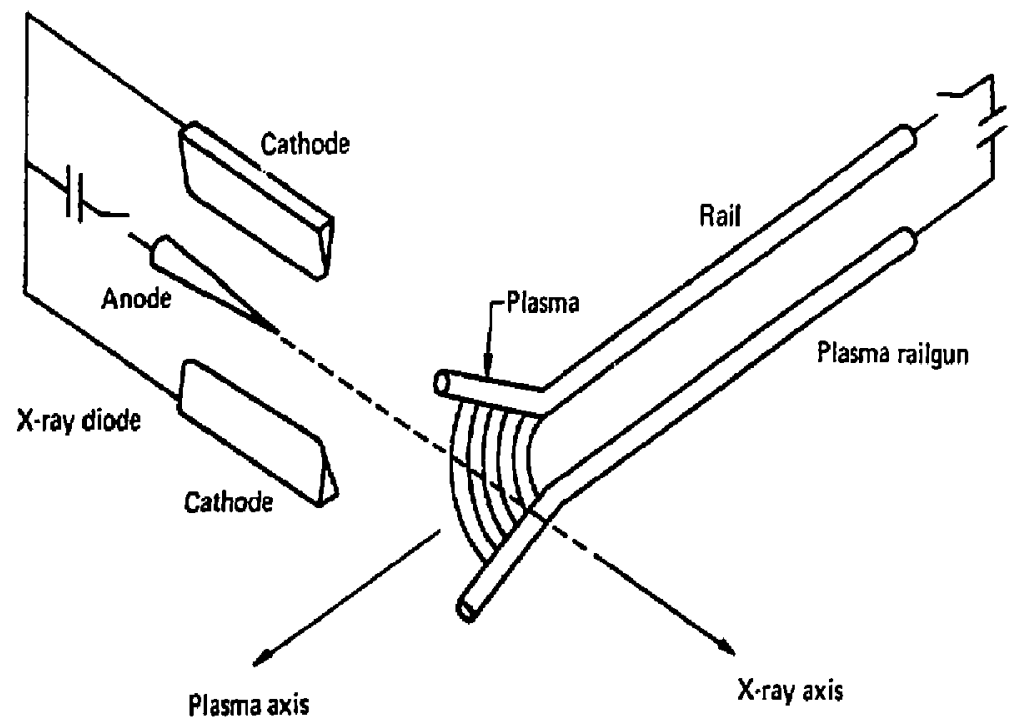

FIG. 3. Amangeneat of $x$-ray tube. 
A plasma source with a particle density of $10^{21}$ ions $\mathrm{cm}^{-3}$ is being developed to block target reflected light from reentering the laser amplifiers on the Shiva/Nova system. A capacitor bank produces a cutrent that heats a metal foil or wire to burst, producing a plasma. Contained in a railgun geomelisy, the plasma is magnetically propeled across the laser beam path. Current djagnostics using a Faraday cup and glass witness plates measure plasma velocity and density. Using the water Blumlein, a second, more accurate method of determining plasma density is obtained.

The $x$-ray tube is mounted $90^{\circ}$ from the plasma axis and a film pack is positioned within the axis of the $\mathrm{x}$ rays ( $\mathrm{Fig} .3$ ). A radiograph is taken of the plasma and compared against a step wedge of alurtitum and copper foils positioned within the field of view. Figure 4 shows a uniform plasma

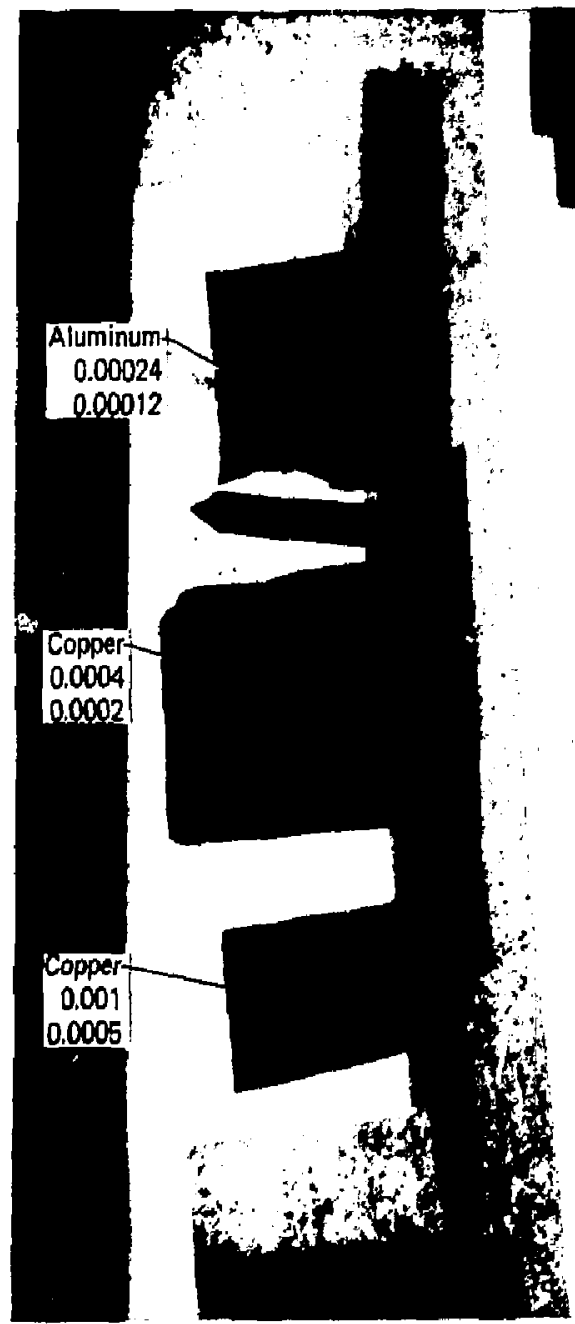

Density stepmedge

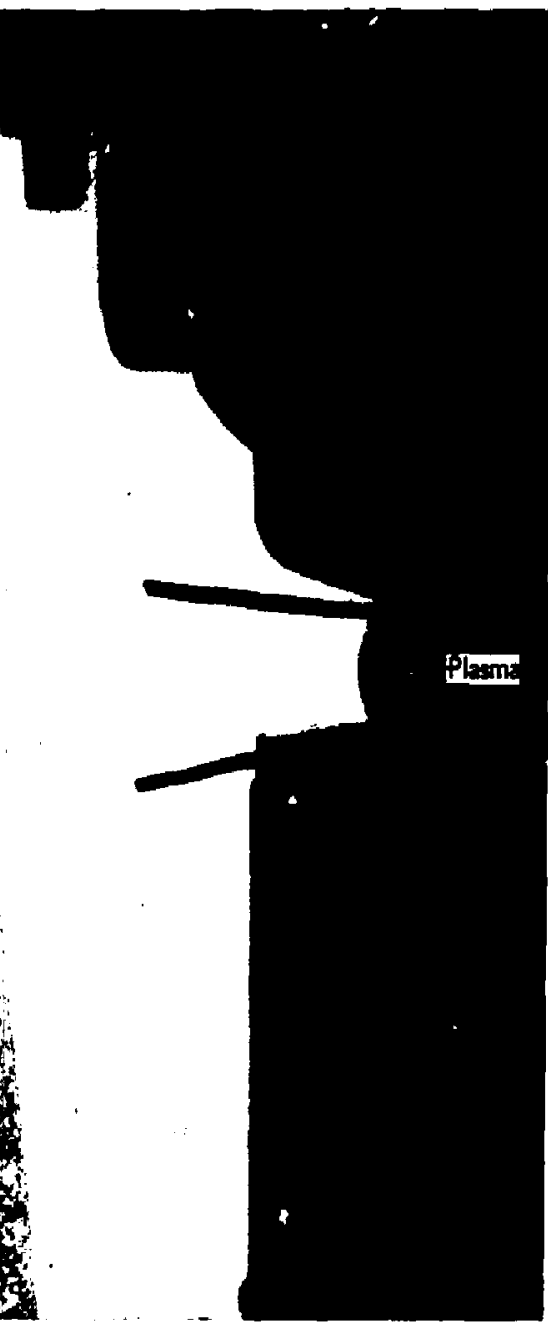

Plasma emerging from chip

FIG. 4. A wiform mann propelied 5 wo. 
propelled $5 \mathrm{~mm}$. Using the water Blumlein, new plasma chip designs have been lested producing the most efficient plasma 'o block all renected light.

(For further infornation, contad W.8. Groham, Exl. 2.9649.)

\section{Stress Rupture Test Systen \\ Developed for Composite \\ Pressure Vessels}

Long-ierm performantex of high pressure composite vessuls (Kevlaracoxy) is being eviluated by LLNL projest teams. The extreme importance of this cyaluation led to the csablishment and a recent upgrade of the lydratulic stress rupture testing system in the Division's High Pressure Engineering facility, Building 343.

A major concern associaled $w$ ith high pressure composite pressure sessels is the lime-dependent failure criteria when the vestels are subjected to various stress levels. The long-ferm stress rupture szstem was developed to permit accurately setling and controlling the dillerent saress levels as a function of tims. The entent with ciils systent is to achieve such control by using high pressure plumbing hardware with precision gauges and transducers. The lest units are conjlected to the system where the temperatute is maintained nearly conslant within a lew degrees of $80^{\circ} \mathrm{F}$.

Aircraft hydraulic fuid (type 5606 ) is used in the system (see Fig, 5) in current terting of vessels for the National Aeronatics and Space Administration. A feature of the long-ierm stressruplure system includes placing more than 100 lest units on station at sevejal pressures. Test pressutes up to 50000 psi are available for different coniposile pressure vessel design configurations. The system illustruted in Fig. 5 can he used in eilher manual or instramentation mode. The manual operition indicates the time to kature (minutes. hours. days) for the vessels. This is uecomplished by actually checking the units on a regular basis by using the gauge and hydratilic supply system. The instrumentation mode. howeter, allows the experimenter to use various types of instruments, such as a pressure transducer, and strain and circumferential gauges. The data acyusition system associated with this instrumentation mode enables the lest results to be secorded on tipe

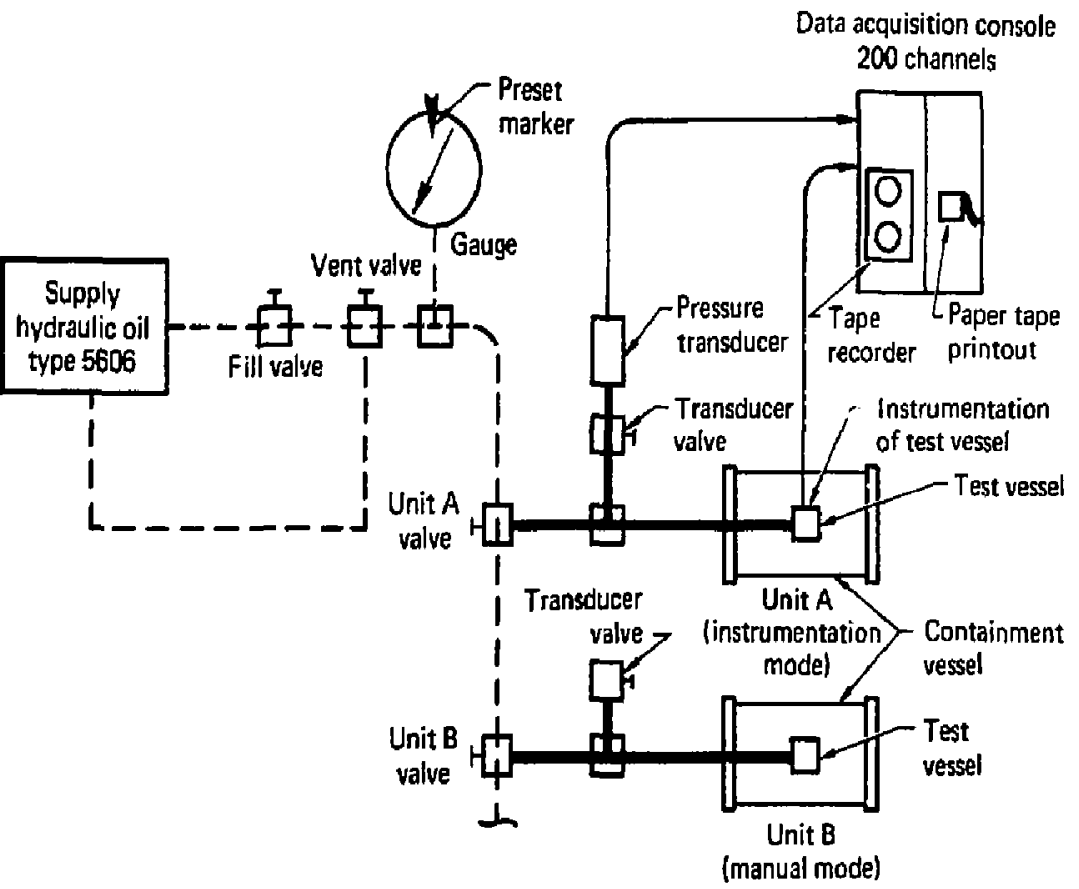

FIC. 5. Lomg-term stress-rupture-yystem installed in Building 343. 
The unis on fest are enclosed in a steel vessel that contaits all the fragmentalion when the pressufe vessel bursts. The conlainment vessel is designed to saljsy the salety tequirements of the Mechanieal Enginetring Department.

In a typical experiment. 10 to 30 yessebs may be stored at three pressure levels al the long-term stress rupture facility. The desire is to combine the test results from the stress rupture experiment with the appropriate analysis. Then we can expect to predict satisfactory performance of the riber-reinforced pressure vessels for their final application.

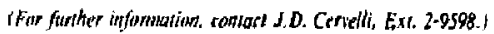




\section{WEAPONS ENGINEERING DIVISION}

Weapons Enginecring Division (WED) is responsible for engineering activities supporting nuclear weapons development, production, and maintenance of a major portion of the nutional stockpile. In providing these services, the Division keeps abreast of new developments in salety, weapon control, and guaranteed weapon life extension.

Our activities include new weapon development, environmental testing, weapons control and enhanced safety, injtiating systems development, engineering technology, and special matcrials procurement. Production work involves communicating product definition and design intcnt to the DOE contraclors responsible for component fabrication and assembly. In addition. active monitoring of the stockpile requires a large elfort in disissembly surveillance of stockpile wuapons to ensure that design reyuirements hirve indeed been mel and to monitor physical changes that may eventually limit the useful life of a weapon.

The Special Materials (SM) office purchases goods and services from integrated contraclors. military commands, and other governmental ugen. cies for all ILNL progerams. This office is also responsible for coordinaling Laboratory guidance on weapon development activities by the integraled contrators. purchasing special isotoper used in a variety of programs, and providing the DOE with a forceast and management plan on nucleat material usige.

Because of classification restrictions, none of the numerous signilicant and important activities of the Weapons Engineering Division for the period covered by this issue of the Technical Revicw are being reported.

(For funher information. contuel R.E. Clough, Ext. 2.872I.) 


\section{ENERGY SYSTEMS ENGINEERING DIVISION}

Our division provides mechanical engineering support to the Laser ( $Y$ ) Program in two major categories: laser fusion (LF) and laser isolope separation (LIS). The LF effort is directed at understanding the basic physics problems associated with imploding small fusion targets with high power lasers. and at developing a fusion process to provide an unlimited sousce of power for use during the next century. In the LIS program, coherent laser light is used to selectively photoionize atoms of a given isolope in a malerial containing several isotopes. The ionized atoms can then be separsted and enriched using extractor/collectors. Each major category has both military and civilian applications.

We highlight seven accomplishments in this issue that help to illusirate the work performed by the division.

- Ahoul 20\% of our manpower is atlocated to the Nova and an interim laser fusion research facility. We are helping to analyzt, design, manufacture, and assentble components so that these Facilitits can be complesed on schedule and within budget. Several unique ispects of these components are summarisd.

- Fabriation of fusion targets is enhanced through the use of microradiography, which permits opaque targets to be completely inspected in only ti minutes. Proviously, it had required 1102 dilys.

- He describe an ultriviolet holographic microinterlerometer which permits picosecond probing of laser-induced plasmas. The microinterferometer provides time- and snace-resolved photographs necessary for understanding characteristics of enerey absorption processes.

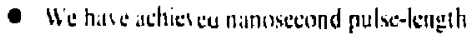
lantr action uxine nelisstahle sclenium aloms. This

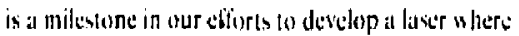
energas an he added :nd slored in long-lived exciled stales, then extracteu rapidly to achitwe high output powars, Some piltsics and enginetring questions must still bo resolved before stelenium listors cun hecontc tomputitise for laser fusion applications.

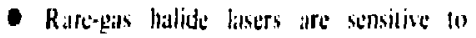

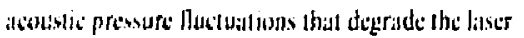
wupul power. We orereane this problem by adding

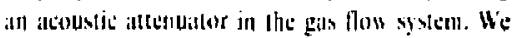
hilse now ishiced suiput pouters that are a linear function of the pulse repetition frequency, with it max:mum value of $55 \mathrm{~W}$.

- Our first large-scale LIS facility (Mars) for anriching uranium has been consiructed and is currently undergoing activation: full-p̧ower operation is scheduled for the summer of 1981. Th: facility will be used to address large-scale physics and angiriesring issues.

- We have developed compact inexpensive heal shields that provide enough thermal insulation to yield optional plasma tube temperatures for a discharge-heated copper vapor lastr. Of three heal sticield designs analyzed, one constructed of fibrous alumina ceramic eliminates plasma tube failure due 10 dielsctric brakdown.

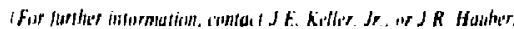
Inll of F.U. ?.758:.

\section{New Mechanical Technology Marks Design of the Nova Laser System}

The Nota Latser Fusion Rescarch Fatilit?. which should be operistionial about 1985, will provide a netl sool in studs meteats ustapons physics and inerlial conlinement fusion.

The Depirtment of Energy has approwed Phasel conslruction of 10 laser hesims arnd associated laboratory buildings. Funding for Phase II, which includes the remaining 10 beams and harmonic conversion crystal arrags, is under consideration by the DOE.

Betive'n now and beginning operation of Nowa, an interim machine will be buik. It will have two beams identical to those of Nova and will probahly use the Shiva target chamber. Shiva and Argus will he shut down by mid-1981 and operation of the interim machine will commenes in late 1982.

This program is consistent with the goals of building a series of increasingly pouerful and energetic lastr systems of advanced concept. Nova will be the sixth mujor system al LLNL (see Table 1). All of the machints throvgh Shivs have neodymium-glass systemls at a satelength of approximalely $1.06 \mu \mathrm{m}$. Nova also will have the capability of operating at shorter warelengths of 0,53 and $0,35 \mu \mathrm{m}$. 
TABLE 1. Chropslogy of neodynium-glass laser development at LLNL.

\begin{tabular}{|c|c|c|c|c|c|c|}
\hline Vane & $\begin{array}{l}\text { Power } \\
\text { (TW) }\end{array}$ & Enery & lonthe & $\begin{array}{l}\text { Fint } \\
\text { opratienal } \\
\text { dete }\end{array}$ & $\begin{array}{c}\text { Cont } \\
\text { of dillors) }\end{array}$ & Accoondistanents \\
\hline Cyches & 1.0 & $\cos \mathrm{s}$ & $100 \mathrm{ps}$ & $1973-74$ & - & Laser chain developuent \\
\hline Jams & 0.4 & \&uj & 100 H & 197475 & - & 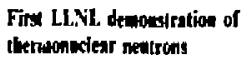 \\
\hline args & 5 & $2 \mathbf{k J}$ & $50 \mathrm{ps}$ & 9976 & 4 & $\begin{array}{l}\text { Shorter ware length target } \\
\text { conpling }\end{array}$ \\
\hline Shiva & 28 & $10 \mathrm{~kJ}$ & $350 \mathrm{ps}$ & 1977 & 30 & 100 tines D-T liquid density \\
\hline Novette & 20 & $20 \mathrm{~kJ}$ & 1 as & 1992 & 18 & - \\
\hline Nave Phace I & IIOO & $100 \mathrm{~kJ}$ & $1 \mathrm{~ms}$ & 1955 & 145 & - \\
\hline Norn Phase II & 200 & $200 \mathrm{~kJ}$ & $1 \mathrm{~ns}$ & Late 19805 & $195^{2}$ & - \\
\hline
\end{tabular}

The etinated cost will be S238 nillion with shorter wivelength capsbility.

Development of this series of laser machines has required rew engincering approaches thill deparl from elassical lines. This has crealed al mechunical technology unique to laser fusion enperimentid systens. We are applying much of this lechnology to Nova in the advanced amplifier design. sleun facilitiss, stable optical supports. and the design of a syatern dedicited to esficient mainlenince so thal our goal of mavimum performance will be realized.

The LLNL laser lechnolog: also is heing 1rinsferred to the British for their Helen laser at the Alonic Weapons Research Establishment (AWRE): to the Japanese for their 12-arm version of Shiva, nalmed Gekku: and to the French for their proposed Nowatike two-beam systen called Phébus. Sume of the Lahoraltory"s neu icthnology is describud in this summotry.

This design work is being done by the following members of the mechanical systems group of the Nova project: J. R. Braucht, G. S. Bradley, J. B. Canfield, M. G. Demos, F. A. Frick, B. M. Gim, C. A. Hurley, G. C. Lee, A. Martos, C. B. McFani, Jr., R. C. McKee, H. J. Rien, R. L. Sites, I. F. Stowers, M. D. Virgino, and D. L. Walis. These are supplr lented by a group of Kaiser Engineers personnel headed by Howard Julian.

\section{Disk Amplifiers}

The full Nova nachine will requite 280 disk amplifiers. One hundred of these will be salvaged from Shiva. The rest ase new "box smplifier" designs with apertures of 20.8,31.5. and 46 Lm thitl incorporate all the latest innowations of amplifier technolugy.

Box amplifitrs are similar to the earlier disk amplifiers in several ways: the basic siements of disks. lamps, rellectors, and their clost-packed relationship with each other, have not changed. However, the hox design allows us wo huild lirece disk-contianing amplificrs more coonomica!l! ind simpler than previous amplifiers. Figure I shors a

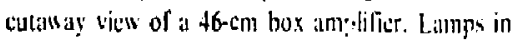
two opposite planes pump the disk latees. Light passeses through the disk betore striking wher Diushlumps.

The pump cavity is a rectangulater box with sir retlecting sides. Glass is pliced between the lintrow and disks (Fig. I) to protect the dish, froml corr.

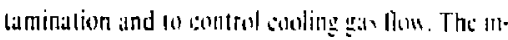
ner box offers masimum relletersity of the pump light.

The panterity is electrically isolused from the external hos. This isolattion guard the

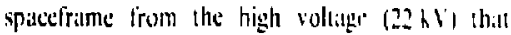
would be caused by flashlump failure.

Easy asembly of lewer parts is compultilute with ceanliness and sale handling of the expensise

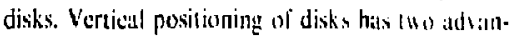
luges: they cant be kept cleaner a herrizombit surfice collects more contaninants than a sercueal one) and will not detleet from their own scight.

The disk holders and rellectors are fislricited by electroforming. a cort-eflectise process which eliminates 30 \% of the mathining normith required for inese shipes. Flashbumps, bickeded hy crenulilled 


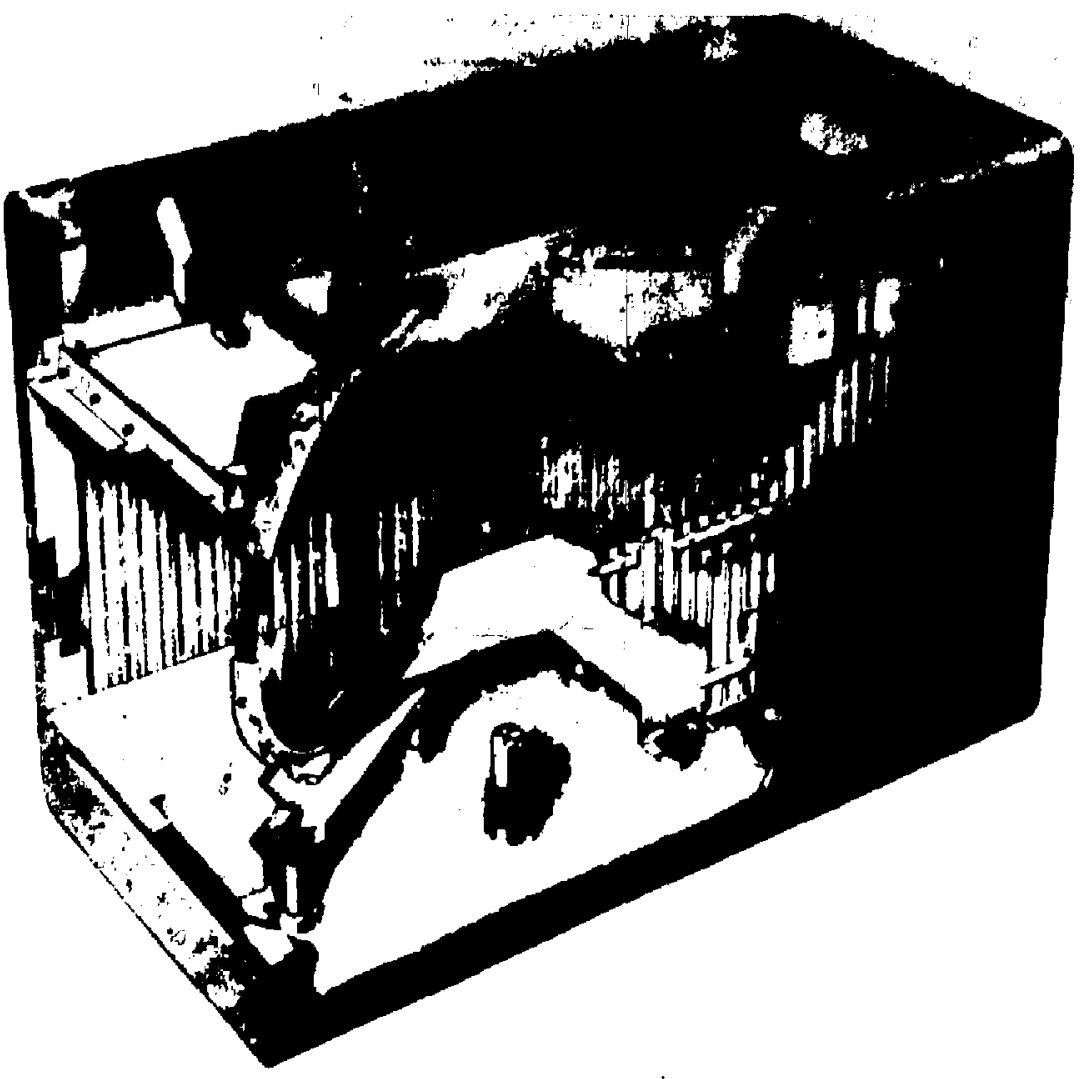

FIG. I. I 46-cm clear aperture disk asplifier. Neolyniun-galass split disks and transrerse flashlamps are unique features of this box amplifier.

fellectors afe mounitd to the side cowers. For succesful fintal issembly. strict uttenlion inust be pilid (u) fouls, procedures, listiners, ind fits. co that no cont:minians are generated. Herc dedicated design 16 simplicit. ass off for edsiter distembly.

\section{Spaceframe'}

Systum stability and accessibility are discetly related (1) the spitceframe, which rigid!y supports and is a key element in maintaining the alignnent of the totill system. Therrmal and vitrationai stabilite: are tine primary requisenents of the spactirame. which consists of four major elements. There are wast and west laser frames, a switthy ilod frame. and at larget frame: The length of the mashine is approx. imatcly 500 fe from cast w 4 col and approsimlalch!

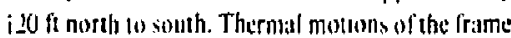
are kepl sithin toleruble limils by the stricll: specifitd building environment.

Vibrutional effects were modeled by simulating the motion of the frames using SAP4, a structural ulalysis code. For each frame structure, we performed a modal analysis to estuthish frequencies and mode shapes. The respunse of the structure wus cvalualcu by performing a dynamic analygis using uctual measured forcing-function data.

the underormed latier frame and iwo hight:order inodul shapts are shown in Fig. 2. Deforniltions of the fratuse were obtained using the measured forcing-function datis. Defornations "ere within 


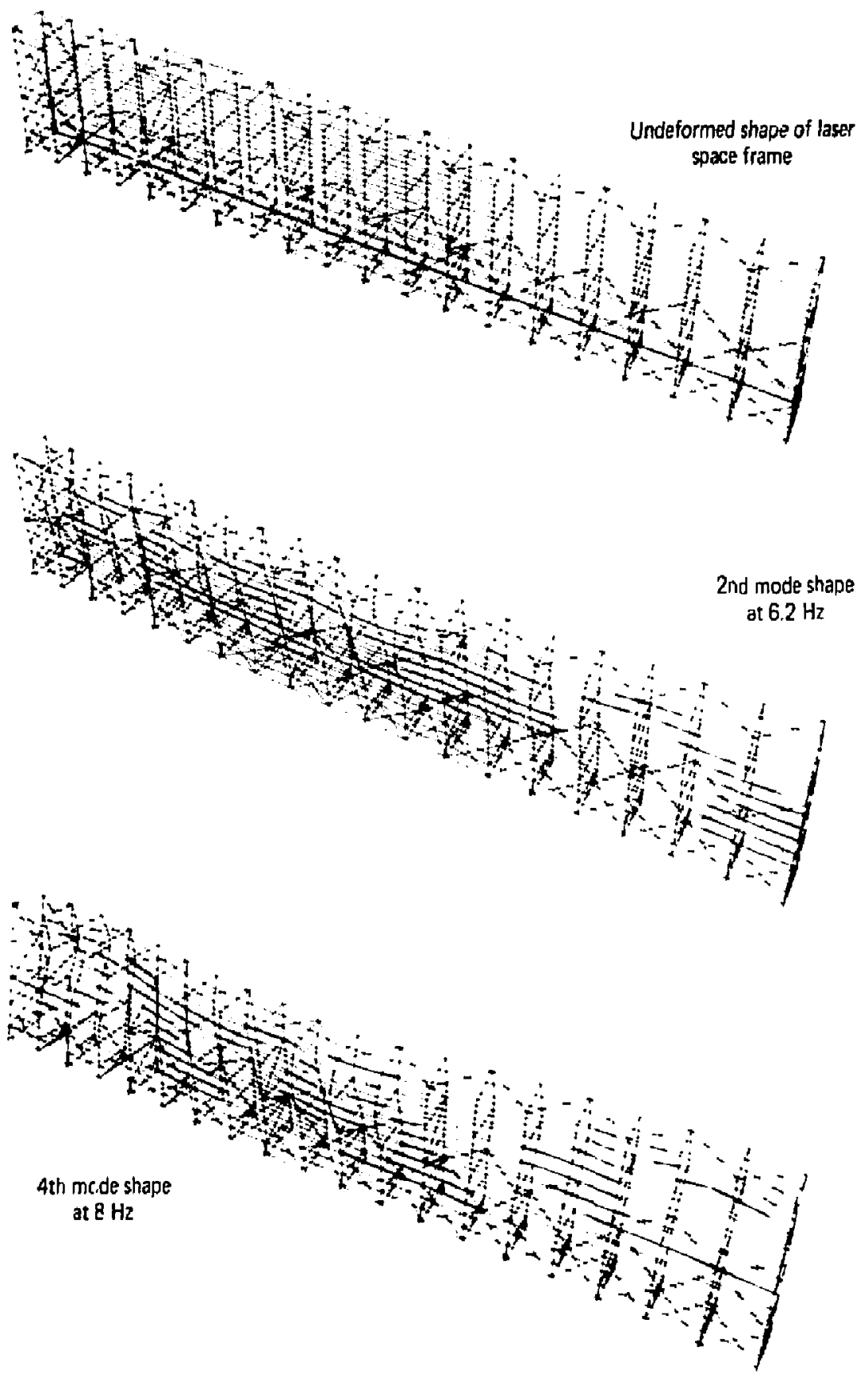

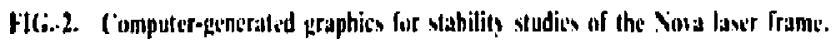


acceplathle limils with a inasinum iranstation of $3.145 \mu$ mand a mavimum rotation of $0.972 \mu$ rad.

\section{Spatial Filters}

Spatial fileces, lucated hetweren amplifier stites. control heiln propagation by filtering. relaying, and expanding the heam. There are seven in tiath liser challin

Thes will be fixed to the spacterame and the kenses wall be hrought on the beam axis witj lens andjusters thitl halve the sapibility of moving each fens in the 1. 1. and , difctions under full vacuum.

fictum in the four largest spatial fillers will he nlustinned with 1000 liter s eryogenic pumpts. The

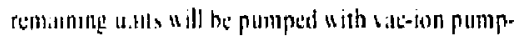
Hat $\$ 4: m$.

\section{Sintern}

The collomes naturt of huge uptical systems rt-

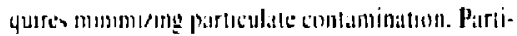

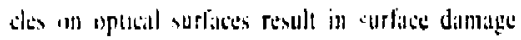

When exposed (1) Mashlamp or laser light. Stcondiy. the units, the handling equipment, and the system must be designed so that everything can he reliably and exsily maintsined.

Becuuse large comporants such ds the curning mirrors (Fig. 3) need this special attention. the entire machine is in a cliss 10000 clean room. In addition, we have an assimbly clean room of elass 100 which is used for assembling components. This rom will be refurhished fo: handlin: new hardwate.

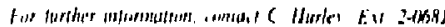

\section{Microradiographic System Developed (a Measure Laser Target Balls}

As part of the fibrication of lastr fuston largets, ve meisure the physieal parimeiters of the target bills before they are irsadiated by the laser.

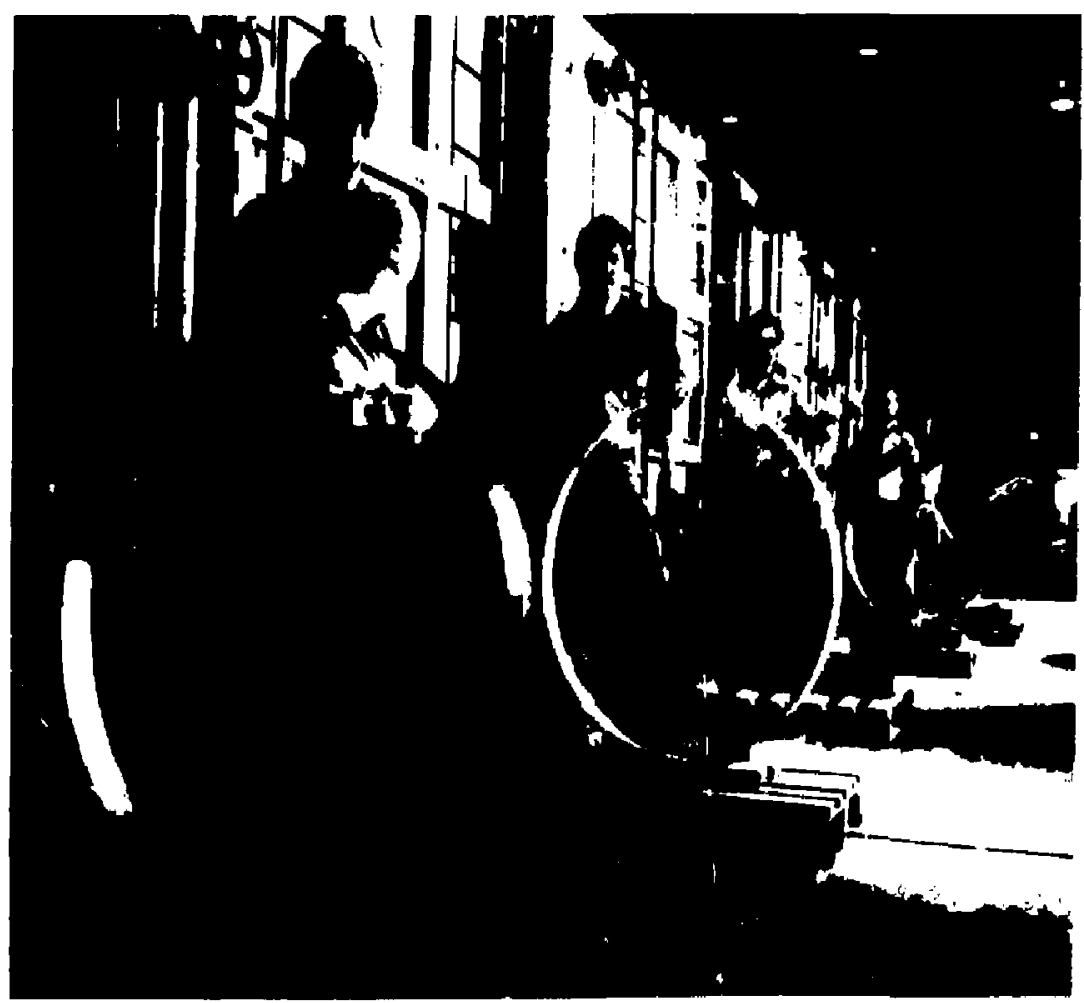

FI(i. 3. Twring mirror Wanks for Nova are mude of borosilicate gluss by Schott Uptical Company. 
In the past. one of our most common targets was a hollow flass micresphter that contained the deuterium-rritum fuel. These microspheres range in diemetur from 70 to $200 \mu \mathrm{mo}$ (0.003 100.008 in.) and have wall thicknessts turying from $0.51025 \mu \mathrm{m}$ $(0.000020100 .001$ in. 1 . Betause these micresspheres afre irillsparem, microinkereroneters have heen used erkensituly to meatsure their wall thickntew and uniformit!. Honeser. recem diretly drisen lister lirgete include morospheres conted with opague list ers of plass ac poly mers ( $\mathrm{CH}_{4}$ or $\left.\mathrm{CF}_{2}\right)$. It is noi feisible lo use mitrointerferonelers to mlitsure the thickness and unilormit! of these coallings, st) ne halve desclopid a meroradingraphic systemll.

The microradiographic system consists of two suparate parls: the monoenergetic $x$-ray system hial generates the $x$ rats to produce the microradiographs. and the Autumatic X-ray Imagt Anafysis System (f.XIAS)' for analyzing the microradiographs once they have been produced.

A monoenergetic s-ray line is desirable because for a given thickness of couting materitul thate is a single energy that maximizes the information recorded on the film plate. If the energy is loo high. there is almost no absorption and the microsphere is transparent to the $x$ ralys. If the energy is too low. the micrusphese is opaque to the $a$ rays and there is no penceration. We citn casily salculate the optimum energy for the microsphere we wish to eramine. and then choose the corract characteristic $x$-ray line.

The monoenergetic $x \cdot$ ray soufce consists of an annular $\mathbf{L a B}_{6}$ culthode. and a conically shaped Hater-cooled anude (Fig. H). The anodes have standard Cajon fittings so that anodes of diflerem malerials may be used. By selecting an appropriate aceeterating voltage, we can excile a churateristic $x$-say line in the anode material. We also obtain background bremssisahlung radiation, hut by carefully choosing the accelerating volluge we can maximize the ratio of the characteristic x.ray line to the bremsstrahlung background.

The spectra produced by our $x$-ray source ean be further improved by uhsorption filtering of the unwanted portion. Figure 5(a) shows the spectrum from a silver anode. The spectrum includes the silver $\mathrm{L}$ line at $2.98 \mathrm{keV}$ : the hremsstrahlung background with superimposed characleristic lines from the stainiess steel walls of the vicuum system: and the silver $K_{\text {a }}$ and $K_{\text {if }}$ lines all 2. .I and $\mathbf{2 4 . 9} \mathbf{k e V}$. respectively: By filtering this spectrun through

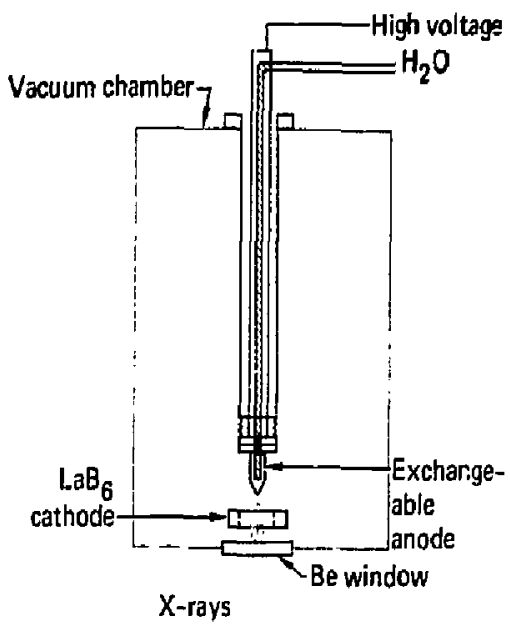

FIC. 4. Monnenergetic x-ray system.
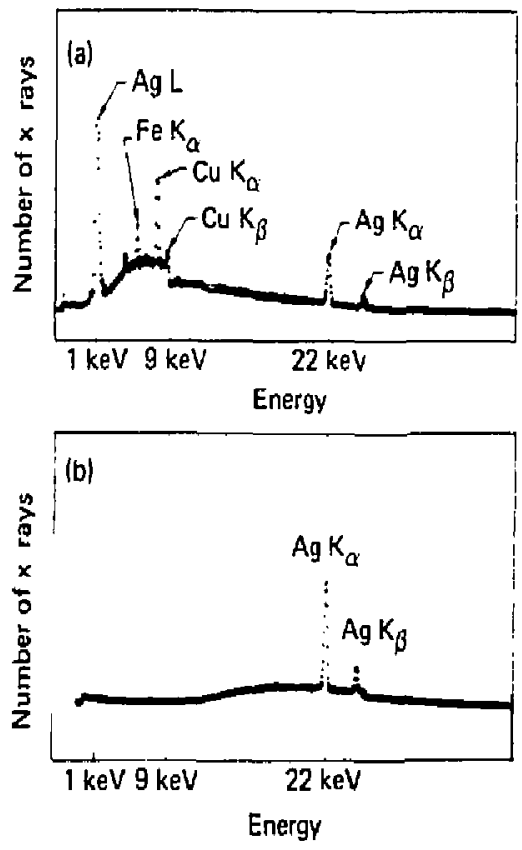

HIG. 5. Specirums (a) from a silver anode at kel' and (b) from a silver anade at tol kel' usick a (1.121-in.-1hick aluminum filter. 
0.020 in of aluminum, we can obtuin the spectrum stown in Fig. $5(b)$. Here we have only the silver $K_{\text {it }}$ ind $\mathrm{K}$, lints.

Onte the radiogruph of the microsphere has bern made. the information about coating thickness ind unformity that has been stored as varialions in filn exposure (oplical density) is analyzed by the AX/AS ststem. The image is magnified with a whits-light microscope. digitized, and stored in an image processor. We can then take optical densily scins across the image and record the density vartalions as a function of positior. Then we use a leastsquares fitting routine to do a four-parameler fi: to the data from the density scan.

To verify the uccuracy of the system, ne used it to analyze several glass microspheres that hord hecr characterized optically with an interferometer. The radiograph, density trace, and fitted data are shown in Figs. 6 and $7(a)$ and $7(b)$. The experimentally tested uncertainties in the measurement of micresphere parameters can be stated as a percentage of the values "easused. There is, however, an absolute minimum. Table 2 shows a list of the iypical uncertainties oi the radiographic measurements and the minimum uncertainty of this technique.

With our new unalytical tapabilities we tan now select a microspherc, radiograph it, and anlialyge the data to the accuracies listed in Table 2. all within 45 min. This is a major improvement over the 1 to 2 dats necessary using our old tichnique and makes the inicroradiography system at useful

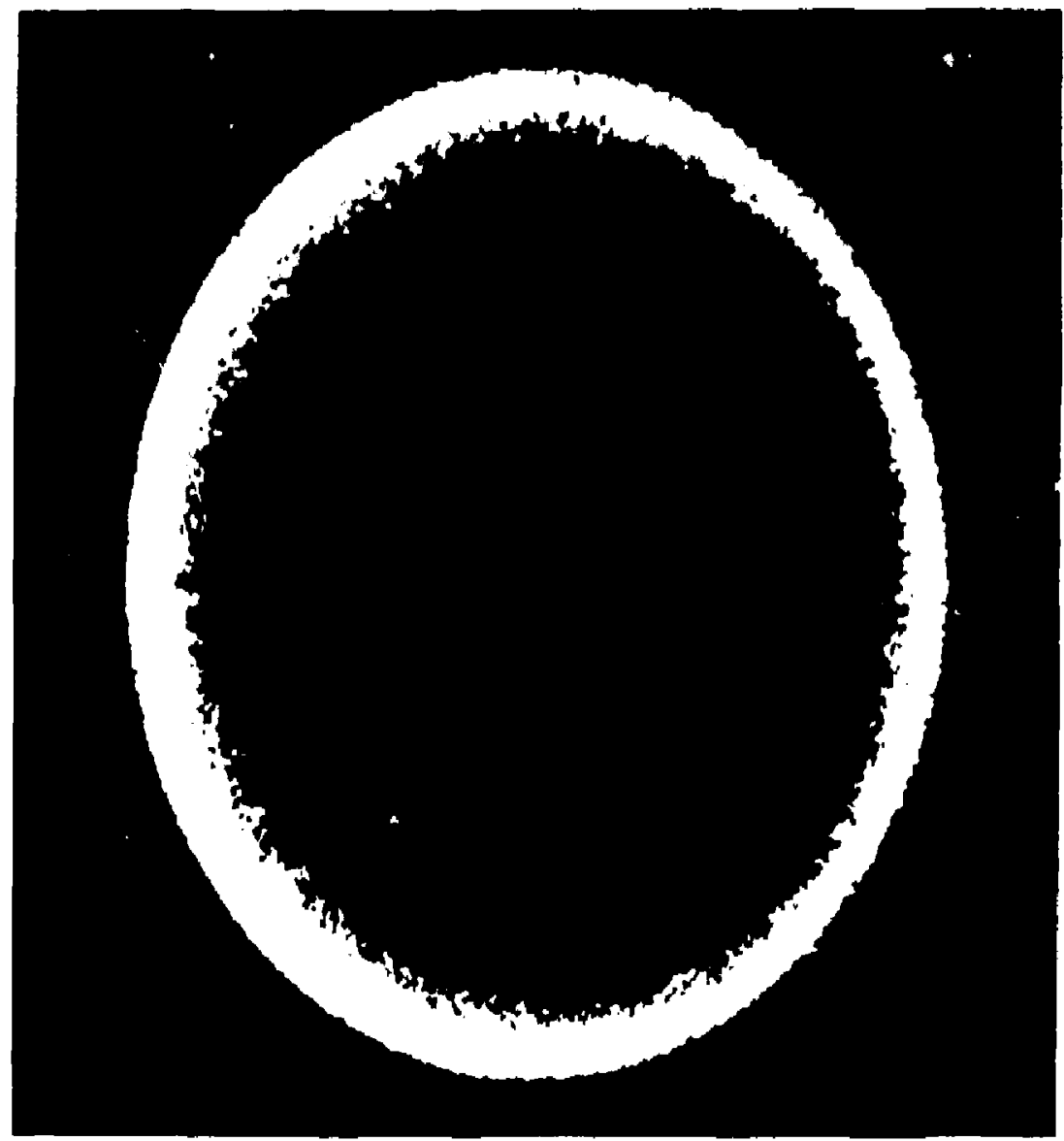

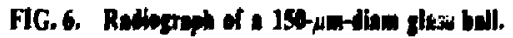




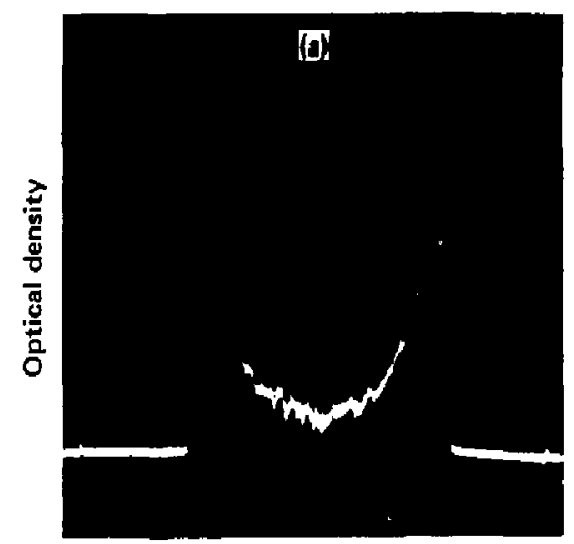

Linear position

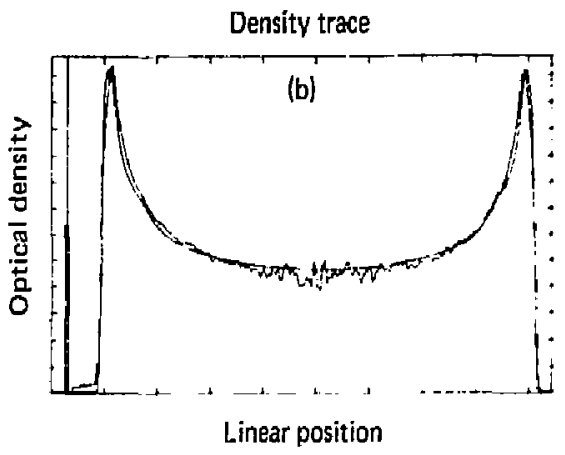

FIG. 7. (a) The optical density sean across the radiograph and (b) the least-squares fit to the data from the density scan.

TABLE 2. Accuracy of the least-squares filling roultine,

\begin{tabular}{|c|c|c|}
\hline Patameter & $\begin{array}{l}\text { Typical } \\
\text { uncertuienty }\left(f_{1}\right)\end{array}$ & $\begin{array}{l}\text { Mlinimum } \\
\text { uncetrinly }(\mu \mathrm{m} \text { ) }\end{array}$ \\
\hline Mineneter & f & I.11 \\
\hline HoH & 1 & 0.5 \\
\hline Souctuscentricit! & 3 (or wall) & 10.15 \\
\hline
\end{tabular}

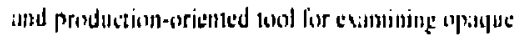
litrits.

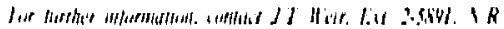

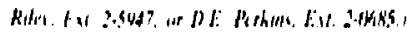

\section{Designing an Ulitraviolet Holographic} Microinterferometer for Plasma Probing

One ol the lechniquss to help understand the absorption of energy within laser-produced plasmas utilizes an ultraviolea holographic microinterferometer. The microinterferometer provides timeand space-resoleded picosicond probing of plasnias with electron densitics of $10^{20}$ to $10^{31} \mathrm{c}_{i} \mathrm{~cm}^{3}$ and density contour velucities of $10^{\circ}$ to $10^{7} \mathrm{~cm} \cdot \mathrm{s}$. Spitial resolution of $1 \mu \mathrm{m}$ or betler with pulse duration of 3 to 30 ps can be obtained.

The design has some main functions. First at portion of the main laser pulse is split just after the pulse sulector and as subsequent amplification. Second, the 1.06- $\mu \mathrm{m}$ 30-ps pulse is filtered and then 
shaped using a spatial filter and apodized aperture. Third, the laser pulse is frequency quadrupled using successive $K D^{*} P$ and $A D P$ frequency doubling crystals. Fourth, to record data an interferometer is used that is simple, fiss entrance and exit ports of the target chamber, has a path-matching capability of $0.5 \mathrm{~mm}$ with access to alignment controls, and has $1 / 2.5$ optics corrected for spherical aberration. Targets used in the experiments consisted of 40-to80. $\mu \mathrm{m}$-diam $\mathrm{SiO}_{2}$ hollow microspheres or balls. The smaller sized balls were used to minimize the effects of probe beam refraction during passage through the strong axial gradient density field. In the dense plasma region, long wavelengths are refracted out at steep angles, missing the collection optics and therefore not exposing the photographic plate. The timing of events was accomplished within $10 \mathrm{ps}$ with the aid of an optical streak cameru.

The plasmat experiments uere ferformed at $1.06-\mu \mathrm{m}$ wavelenglh with ane heam of the Janus laser facility. Incident encrgy on turget was varird between 0.5 and $5 \mathrm{~J}$ in 30 -ps pulses.

The illumination of the larget arsil must be sulficient to expose a holographic film plate of about 3 $\mathrm{cm}^{2}$ area. This requires a lotal UV eilergy on the film plate of $6 \mu \mathrm{J}$. Because of losses in the uplical system. approximtately $15 \mu \mathrm{J}$ ate required at the output of the frequency quadrupled crystal.

The interferomeler is basically a MachZehnder-type except that it is hologruphic and it utilizes a microscope abjective to image the target with micron spatial resolution. Since it is holographic. focusing during plasma experiments is not critical. This is particularly important because the wavelength is ultraviolet. Focusing to micron alcuracy is necessary for accurate interpretation of the fringes obtuined.

The $2660 A$ beam is split by a $37^{\circ}$ prism (Fig. 8) into two beams, a reference beam and an object beim, of which the object beam passes through the
$1.06 \mathrm{~mm}$ laser pulse $0.5 \mathrm{~J} .5 \mathrm{~J} / 30 \mathrm{psec}$ FWHM

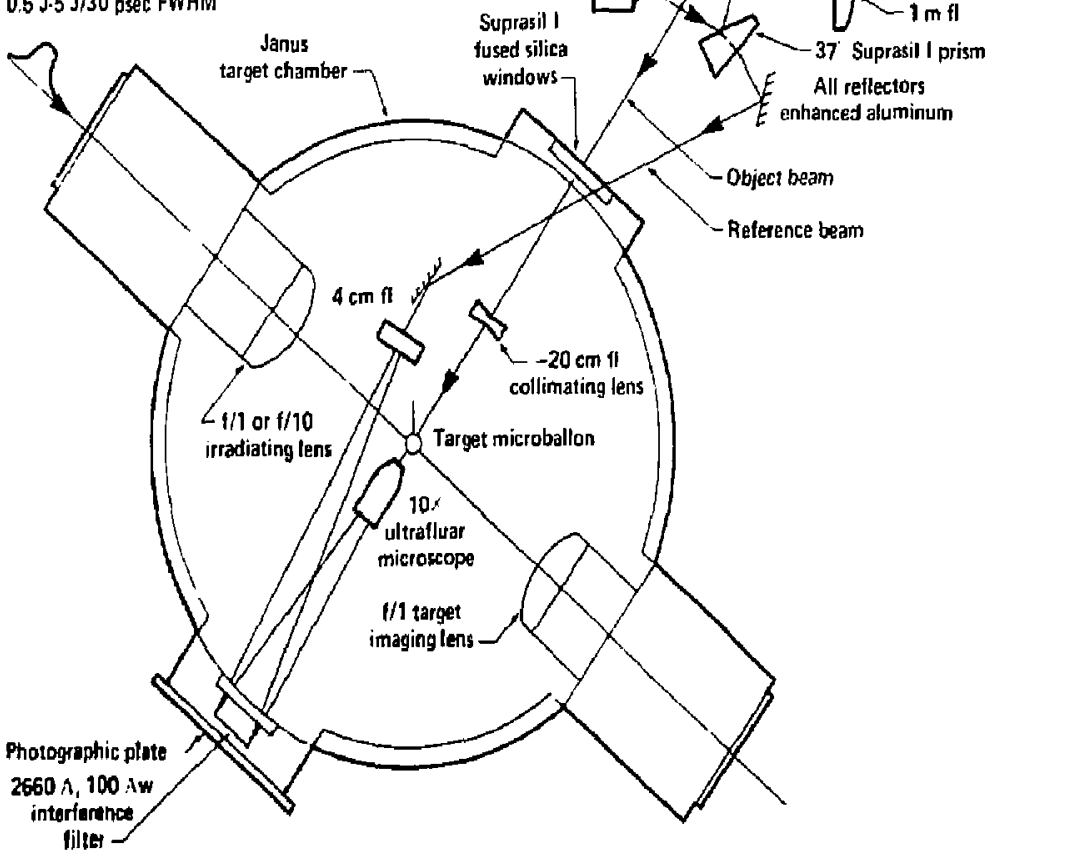

HIt. 8. I'V holographic microinterferometer and target chamber. 
target area. These two beams travel equal paths and then recombine to form very fine i..'erference fringes. Upon reconstruction, the two images interfere 10 produce an interferometric fringe pattern charasteristic of the plasma.

Bright reconstruction holograms require accurate matching of reference and object path ieng ths to less than the coherence length of the laser pulse. For a I5-ps UV pulse the maximum separa. tion of these path lengths is about $0.5 \mathrm{~mm}$. It is therefore necessary to move one of the reflectors with a resolution of better than $0.5 \mathrm{~mm}$ withoul changing angular alignment.

A $10 \times 0.2$ numerical aperture microscope ob. jective is used to image the $40-\mu \mathrm{m}$ diam microballoons behind the holographic plate. The reference beam is expanded by a 5 -cm lens to itluminate three times the area of the object beam at the film plane. The shape of the interference fringes is delermined by the difference in optical path traveled by the light ray refracted through the delise plasma area and the same ray through vacuum. Examples of fringe patterns surrounding laser. irradiated argets are shown in Figs. 9 through 11 ,

The UV probing technique described here provided the most detailed information ever obtained on the plasma surrounding laser/fusion largets. ${ }^{2}$ The first photograph (Fig. 9) shows a 76 $\mu \mathrm{m}$-diam microballoon used us a reference stiot to obtuin proper foeusing. The second is a double exposure hologram with the larget in place and then removed to reveal a set of fringes without being irradiated by the $1,06-\mu \mathrm{m}$ beam. These interferograms feveal the uniformity of the wall thick ness. The third photograph is a shot taken 300 $\mathrm{ps}$ after the peak of the pulse. Here the fringes reveal the electron distribution.

The shape and density of the plasma protrusion in front of the target can be measured by the resulting fringes. It is necessary at this point to be able to resolve fringes with a resolution of I $\mu \mathrm{m}$ to measure density near critical, $10^{21} \mathrm{e} / \mathrm{cm}^{3}$. Figures 10 and 11 depict this plasma protrusion very well. The target in Fig. 10 is a $41-\mu \mathrm{m}$-diam glass mictoballoon, while Fig. II is a $70-\mu \mathrm{m}$-diam paralyene disk, both isradiated with the same laser intensity. The path length in Fig. 9 is seen to be about $20 \mu \mathrm{m}$ for fringe 5 , allowing us to estimate the average electron density in that region as about $2 \times 10^{21} \mathrm{e} / \mathrm{cm}^{3}$. A method of accurately transformiso the fringe full data to detailed point by point electron densities is referred to as Abel inversion. The technique which works for axisymmetric geometries such as ours, has been used by Sweeney ${ }^{3}$ to analyze the results presented here.

\section{Conclusion}

Optical probing through the target atmosphere is an important diagnostic tool for characterizing the plasma asea. This ir wher: the energy is absorbed and eransported to the core region. This instrument then becomes a useful diagnostic tool to
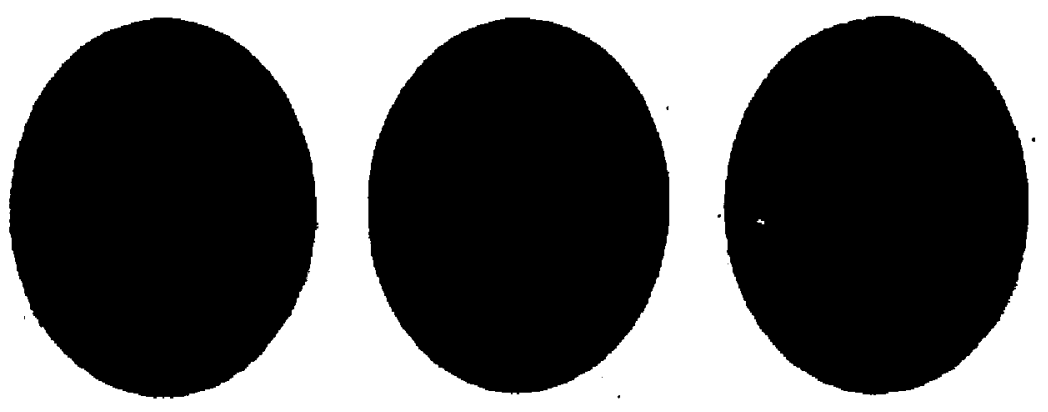

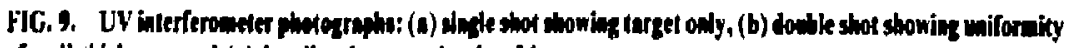
of wall thicksem, ad (c) brabided target sowing frimges. 


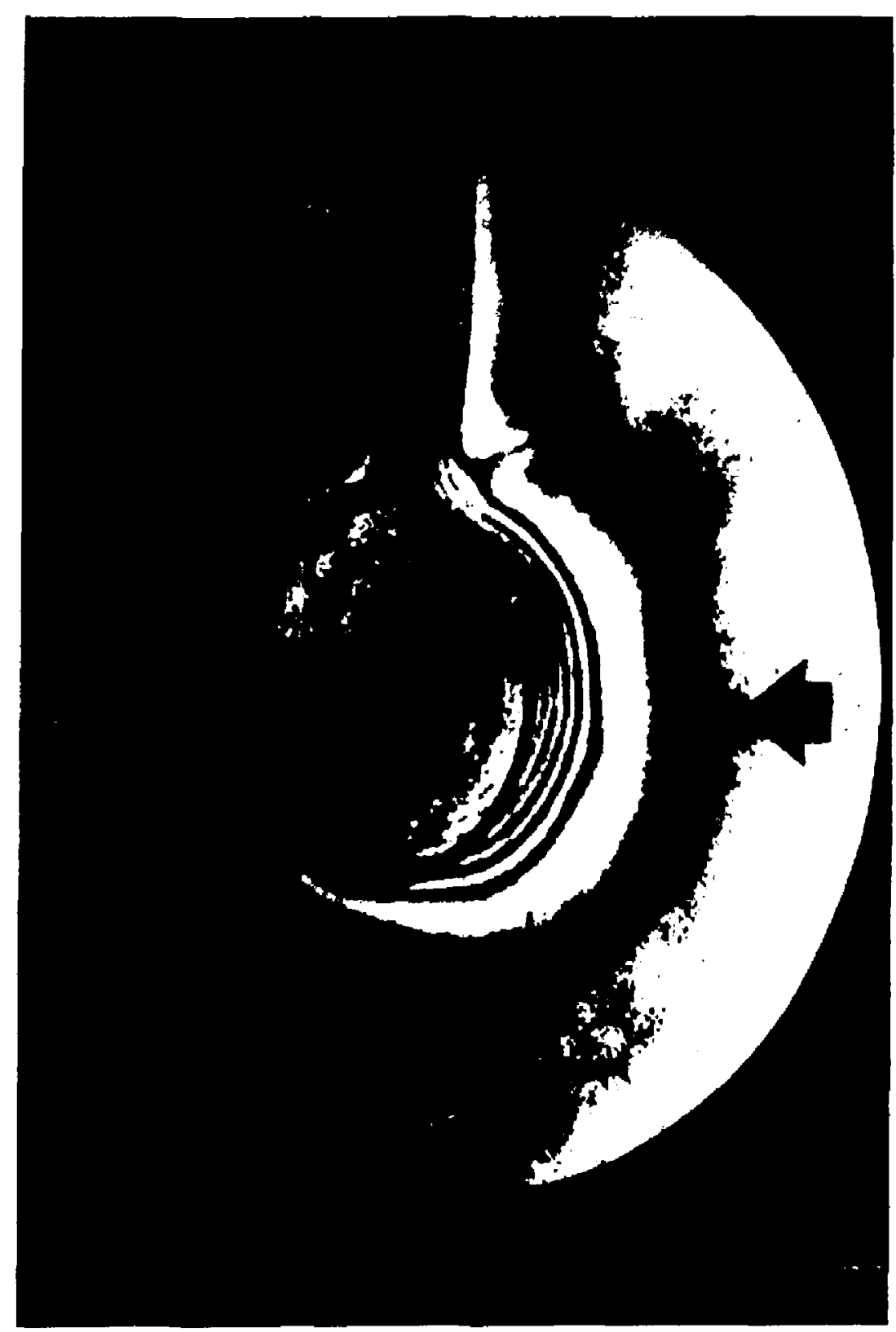

FIG. 10 Irradiated targe illosirating fringes with original larget diameter. 


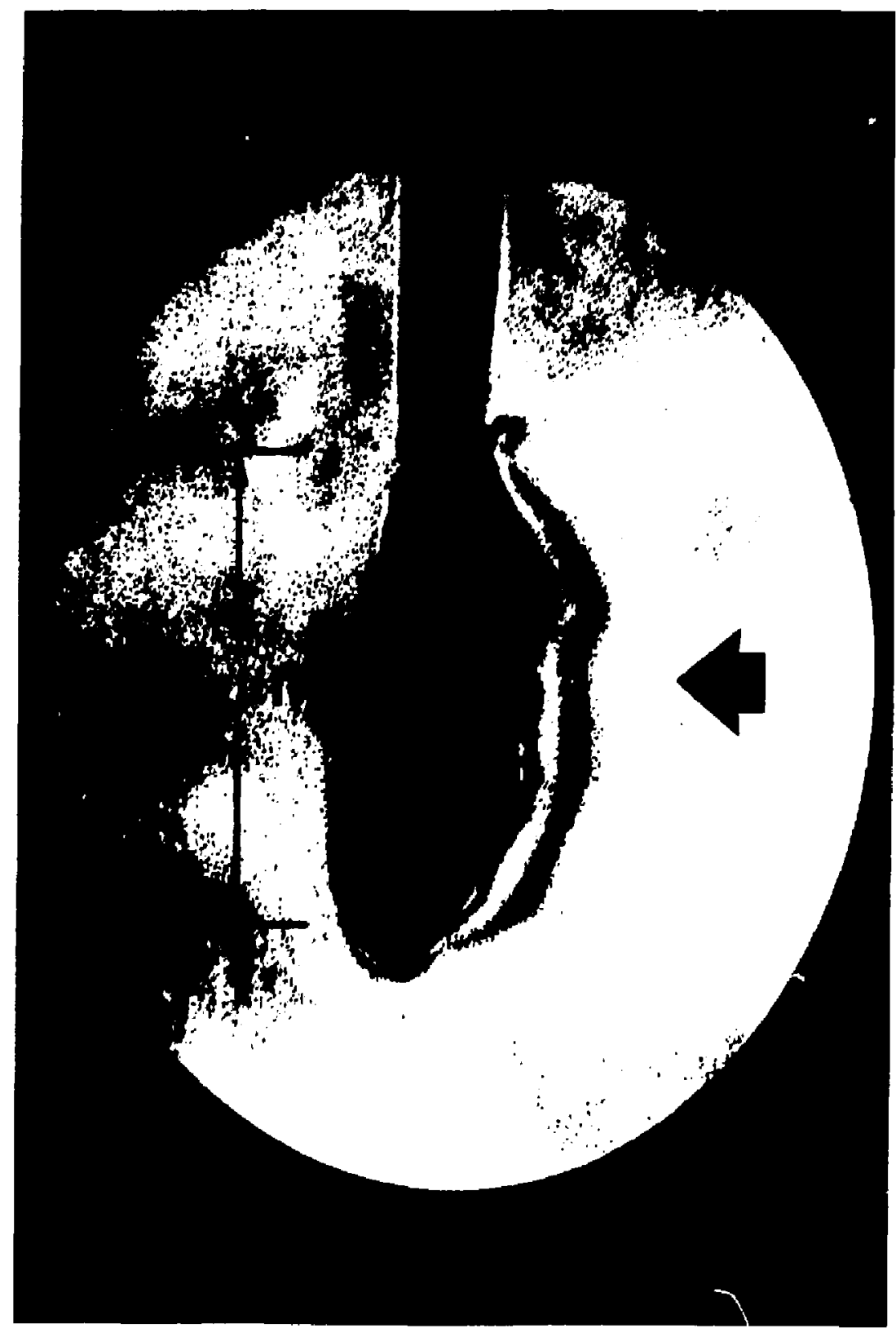

FIC. 11. Irradiated disk, paralỵne tagget, illusirating fringes 
determine the density distribution ${ }^{4}$ in the critical region from $10^{20}$ to $10^{21} \mathrm{e} / \mathrm{cm}^{3}$. Typical target experiments involve $40-\mu \mathrm{m}$ glass microballoons imploded with a $1.064-\mu \mathrm{m}$ 30-ps pulse at intensities on larget of $10^{14}$ to $10^{16} \mathrm{~W} / \mathrm{cm}^{2}$. Resolution was measured to $1 \mu \mathrm{m}$ by measuring the separation of the fringes in the teference hologram and comparing this measurement to the known ball diameter. Velocities as high as $5 \times 10^{6} \mathrm{~cm} / \mathrm{s}$ were observed in triple exposures. Density scale lengths as short as $1 \mu \mathrm{m}$ were observed. From these observations, it is imperative that, in the design of a holographic microinterferometer, ${ }^{5}$ the beam be in the UV and of short duration (15 ps) to probe the dense plasma area near critical density.

(Fos further informativa, contact E. L. Pierce, Ext. 2-5880.)

\section{Lasers Based on Selenium 1S Metastable Atoms}

The laser program at the Lawrence Livermore National' Laboratory continues to seck short-pulse Jasers whith would ultimutcly be capible of achieving the extremely high output powers required to produce thermonucleur fusion of laser-isradiated targets. One upprosch is to store energy in longlived excited stutes (e.g., metastabie states) of a suitable atom and then to extract that energy in a pulse of a few nanoseconds. The selenium laser was recently studied in this regard."

The basic experimental system was derived from eirlite published work ${ }^{7-10}$ and consisted of a high-current-density electron beim source which injecled is beum into il cell filled with high-purity senon giss. The 172-nm wavelengh vacuum ultraviolet (VUV) light produced by xenon excimers (Xei) was then used to photolyze carbonyl selenide (OCSe) in an idjatent cell. Selenium 'S metastable utums were formed by photolysis, providing the busis for lasel ascillation.

Figure 12 shous the energy levels and transition of intertst for selenium. The wavelength of the ${ }^{\prime} \mathbf{S}_{i)}-{ }^{1} \mathrm{D}_{2}$ "auroral line" is $776.8 \mathrm{~nm}$ (infrared) and the advelength of the ' $S_{0}-{ }^{3} p_{1}$ "transiaroral line" is $2 \times k .7 \mathrm{~nm}$ (thlue-greten). Theste names are derived from the names tommonly applied to the curresponding triansitions of oxyen frequently ob. served in emission from the upper atmosphere. The Dxygen ${ }^{\prime} S_{f 1}-{ }^{\prime} D_{2}$ lint is the green emission sten in Ithe ausora horealis.

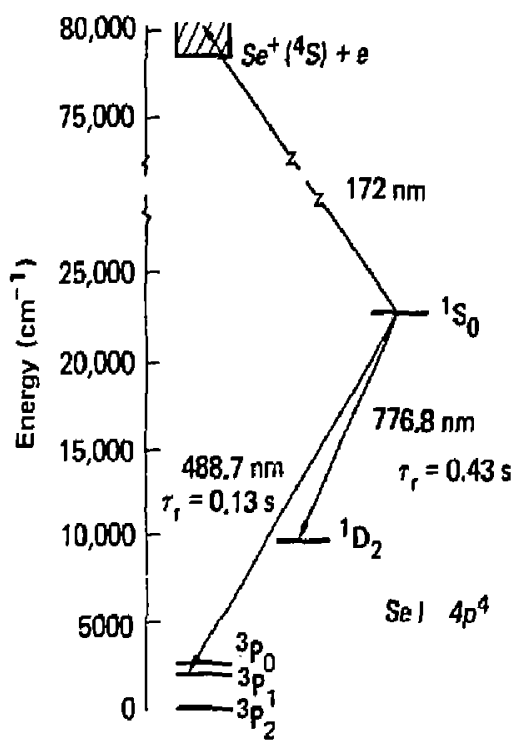

FIG. 12. Energy levels of seleniam. The laser tratsitions of interest are at 488.7 and $776.8 \mathrm{~nm}$. Photoionization of Se ('S) can occur by absorption of the 172-nmo pump radiation.

\section{Apparatus}

The nominal voltage of the electron beam was I MeV for 50 ni. A two-bladed carbon cathode was used to form an electron beam over an area of 50 by $7.5 \mathrm{~cm}$. The cuthode was direcily opposile a ribbed structure which supported a 0.127 -mm-thick vitunium foil through which an electron beam current of approximately $50 \mathrm{kA}$ passed into the rarc-gas VUV cell. The anode wius simply the high pressurt rart'gis cell (Fig. 13).

Identical phololycic cells wen placed al each end of the rare-gas VuV cell. One cell was used for laser work and kinetic sludies (Fig. 14) and the other was used to house VUV pump diagnostics. The photolytic cells were made of stainless steel ind were separaled from the rare-gas VUV cell by magnesium fluoride $\left(\mathrm{MgF}_{2}\right)$ windaws. For fiuotescenct sludies, the excited volume was viewed through $\mathrm{MgF}$, reentrant windows for laser experiments, the mirror mount assembl as shown in Fig. It were utitized.

During kinetics studies. a photomultiplier was used to view Ruorescence through appropriale bandpass filters. To oblain Ruorescence spectra of 


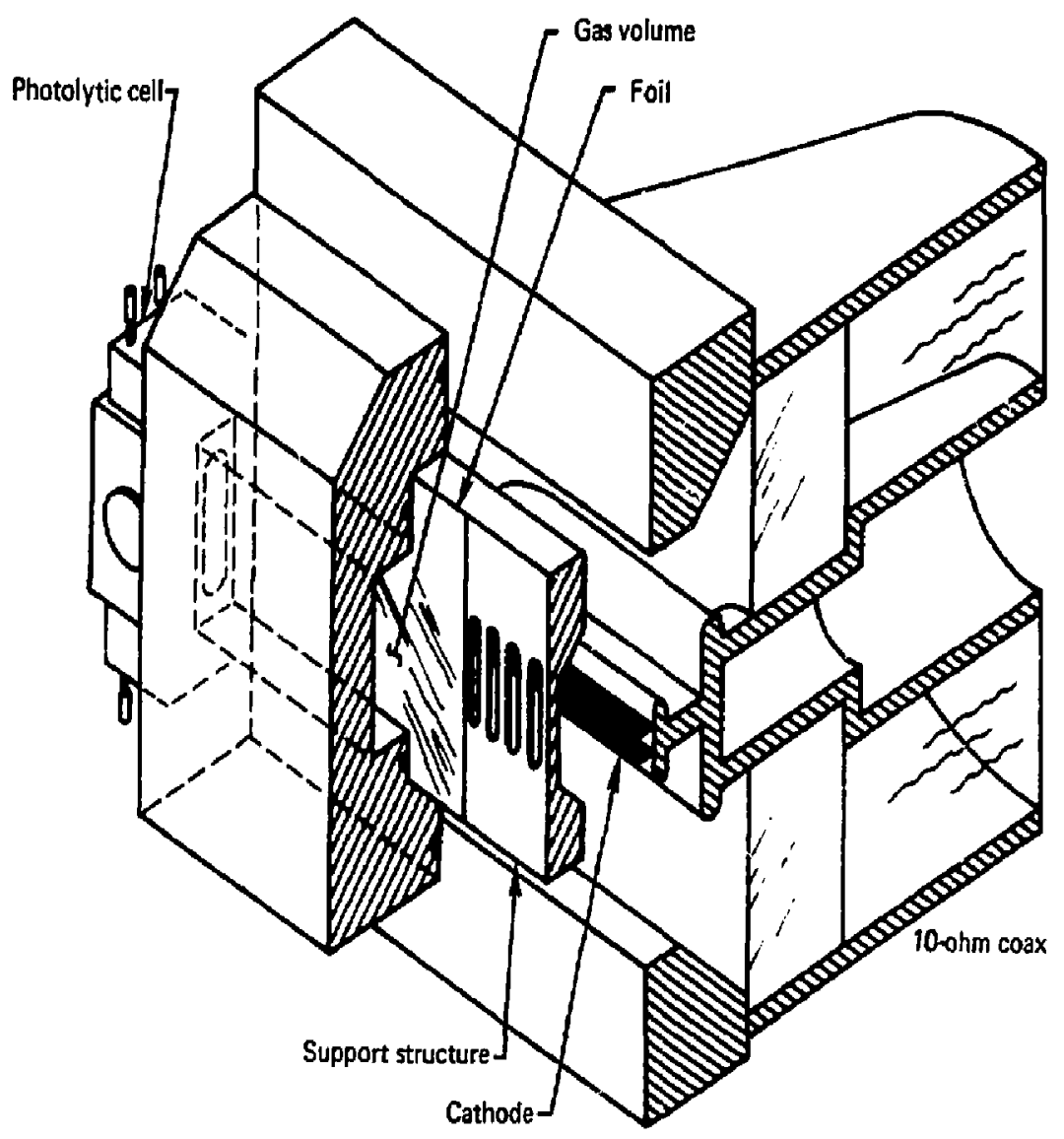

FIG. 13. Cutaway vieh of the olectron-beam source and bigh pressure rare-gas cell used to produce fare-gasexcimer radiation.

the pholvlytically excited gas. an optical multichannel analyzer allached to a spectrometer was used. Laser time-dependence was observed using photodiodes, E-beam-produced x-ray signals ker: reduced by using lead shielding around diagnostics. and electrical interference was reduced to acsepdble levels by using if shielded cubles from the diagnossics to a screen room where the electronic rearouls were housed.

\section{Roulis}

Laser action was successfully achieved on both the 489-nm Se(' $\left.S_{0}-{ }^{3} P_{j}\right)$ "Iransauroral line" and the 777.nm Se(' $\left.S_{0}-D_{2}\right)$ "auroral lise." The OCSe molecules in the laser volume were lotully dis sociated by the VUV radiation.

The large nesenes of ver ridiation uned to photolye the OSCe molccule sere found is product significant consentrattuns of $f$ ist selectrans by phototonizastion of the product 'S itoms. This process is indjatted sthematioully in ry. 12. Tht free electrons can ritpidly deactritat the 'S atoms and thus graull limit lases performancs. Small consentrations of sulfur hexitluoride $\left(\mathrm{SF}_{6}\right)$ were found to counterate this problem be allaching the pholuelestrons so that their quenching wis not signifiusnt. For uptimum selenium laner perlormarces I Torr ar OCSu mixud wilh 5 Torr al SF $_{6}$ 


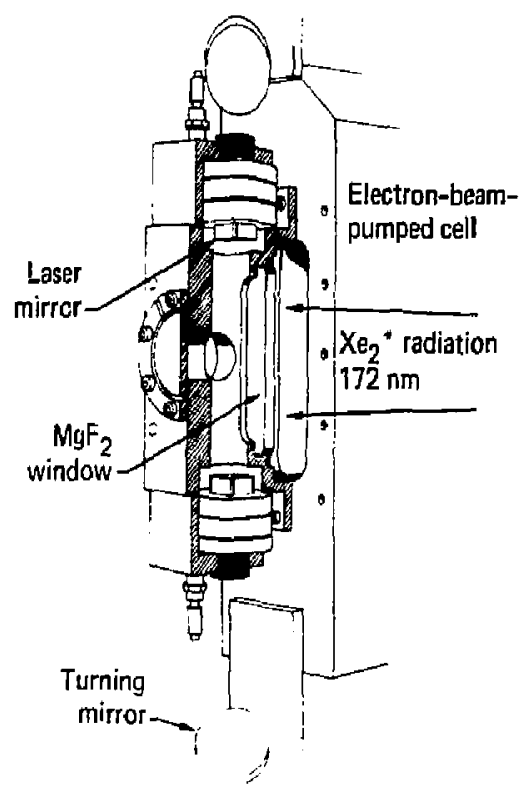

FIG. 14. Cutanay vien of the photolytic call used for experiments with selenium lasers. The laser mirrors are mounted within the cell.

and 50 Torr of $\mathrm{CO}$ was phololyed. The $\mathrm{CO}$ pronided deaciosition of the laser state as well as

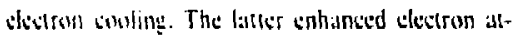
eschment bs $\mathrm{Sl}_{\mathrm{i}}$.

Collision hrosdening and sollision-induced

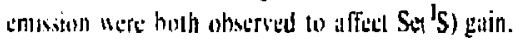
In somjunstlon will this cllkurt. XeSe and KrSe

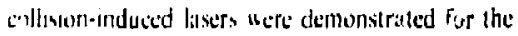
fi s limn simply by andding several atmospueresis of

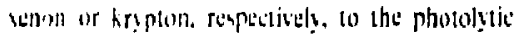
misture.

Lusier perTormance on bot. the $S \mathrm{u}\left({ }^{1} S_{0}={ }^{3} \mathrm{P}_{1}\right)$ and $S e\left(S_{0}-{ }^{\prime} D_{2}\right)$ lines was oplimized by varying the photolytic mixlure, the VUV pump ficence. and the output coupling of the laser mirrors. Liser output was approximitely constan for VUV Aluences beiween 125 and $200 \mathrm{~mJ} / \mathrm{cm}^{2}$. The OCSe was completely dissuciated over the laser aperture for these nucnces. A bove $200 \mathrm{~mJ} / \mathrm{cm}^{2}$ the laser output slowly declined, presumably beciluse of Se( $\mathrm{S}$ S) losses associuted with photoionization. For uplimum con. ditions the oulput snergy from a volume of $6.5 \mathrm{cmi}^{3}$ uid $25 \mathrm{~mJ}$ for the biue line and $16 \mathrm{~m}$ for the infrared line. Although the total energies were small. the volumetric output, about $4 \mathrm{~J} /$ /iter, was respeciable.

\section{Conclusion}

The practicality and potential size of a $\mathrm{Se}\left({ }^{\prime} \mathrm{S}\right)$ laser amplifier is limited by the Se('S) utorage time and the depth of OCSe that can be totally dissociated. Collisional denctivation of $\mathrm{Se}$ ('s) limits the pump duration to a few hundred nanoseconds at 1 Tor: of OCSe. Se('S) lasses assotiated with photoionization limil $X_{2}$. fuences to $250 \mathrm{~mJ} / \mathrm{cm}^{2}$. This fluence is sufficient to totally dissociate I Torr of OCSe with two-sided pumping over a maximum aperture of $14 \mathrm{~cm}$. With that aperture an ouiput luser energy of several kilojoules is reasonable for a $\mathrm{Se}$ ('S) amplifier long enough to produce outputs approaching the window damage limit of $10 \mathrm{~J} / \mathrm{cm}^{2}$.

However, several enginetring problems musl be solved if high energy seleniun lasers are lo hecome practical for fusion applicalions:

- The pump musl he closely coupled to the lasing medium io produse boud light coupling etficiency (prefirably with a large anpect ration of itluminaled height-(t)-photolysis depth).

- Superfluortsitence in the pump must he controlled.

- Broad-area e-beams must bave magnetically isolated modules u prevent beam pinching.

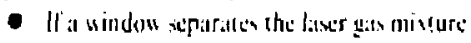

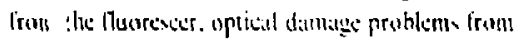
VuV pholons, sattered elcctroms. and $x$ riss as uell as mechingicil lracture due lo thouk wille musl be solvid.

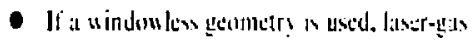
and hyoresecr-ais mising problems must be solsted.

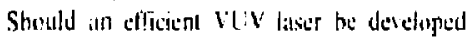
which tould replace the t-heam pumped lithorescer. ste tral of the dificultica jusl foled would not covet. Houever. windom and mirror denage problems would sitil necu solutions.

The selenium laser system could become competitive for fusion applications if answers are forthcoming on the several issues previously mentioned and, more importantis. if other more ef. ficient chemical or kinetic means are found for produclion of the Se('S) excited stale.

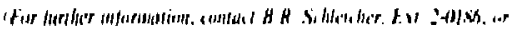
III Pundl. Eu :-6/\$4. 


\section{Acoustic Attenuation in the Closed-Cycle Test-Bed Laser}

The Closed-Cycle Test-Bed (CCTB) (Fig. 15) is a repetitively pulsed, transverse-flow, electricdischarge laser built to determine if Rare Gas Halide (RGH) lasers can be scaled-up to an average power system, in this case typically tens of wolls. One concern is the effect of the pressure waves generated by the pulsed electric discharge on the laser performance. The discharge deposits electric energy into is small volume of gas, the discharge region, heating and partis"ly ionizing it. Because of the very short duration of the electric pulse ( $\sim 100 \mathrm{~ns})$, the gas does not have enough time to achieve thermodynamic equilibrium. The result is an abrupt pressure and temperature change in this region, which can be approximated by a constant volume healing process given by

$$
\frac{P_{2}}{P_{0}}=\frac{T_{2}}{T_{0}}=1+\frac{E}{C_{v} T_{0}}
$$

where $\mathrm{P}=$ pressure,

$T=$ temperature,

$E=$ energy input per unit mass,

$C_{y}=$ specific heat at constant volume, subscript $0=$ at system conditions.

$2=$ after heat addition.

This ratio is lypically in the range of 1101.5 . Alter the electrical energy bais been deposited in the gus. the discharge region expands. reducing the pressure of the system. The region of hot gas is then transported downstrean by the gits now. This expansion of tive discharge region is the source of the acoustic pressure waves which are transmitted and
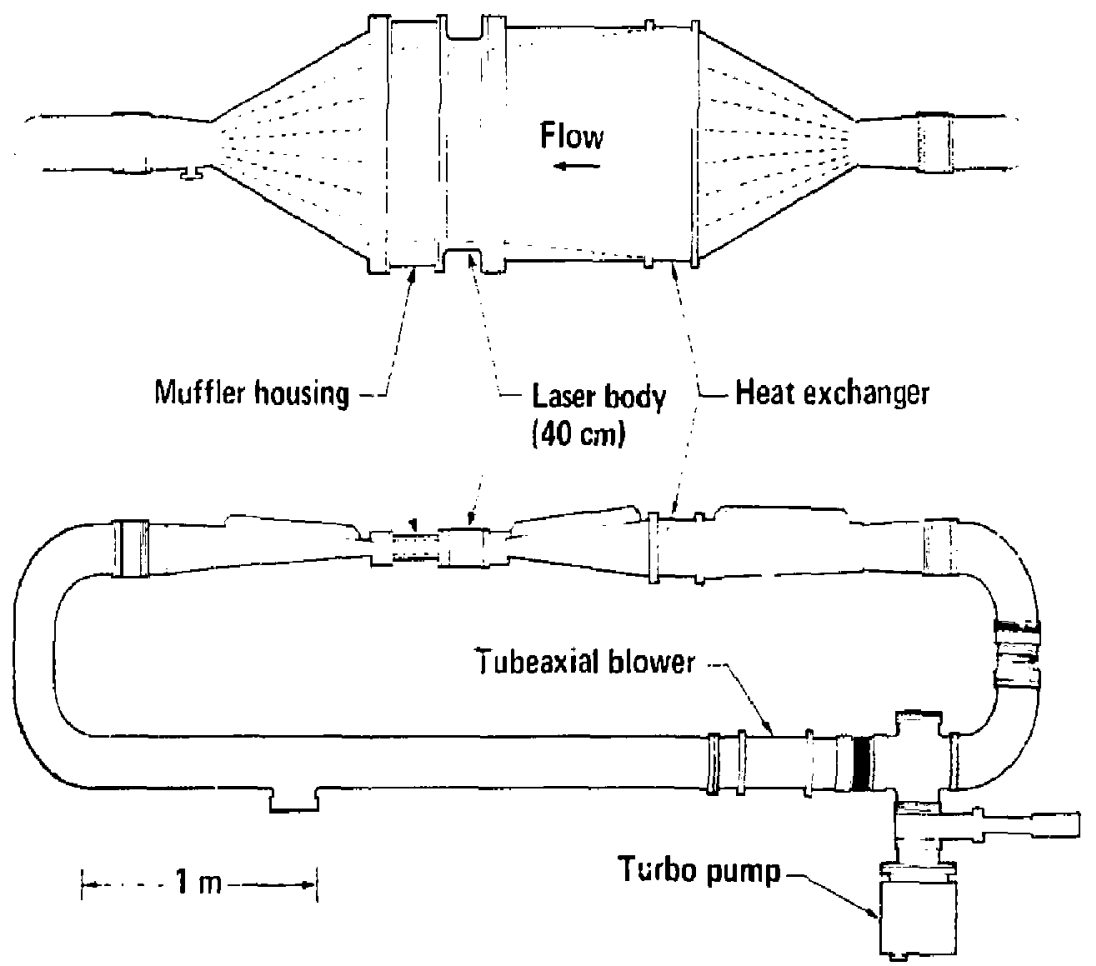

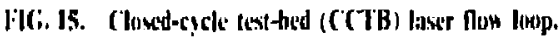


reflected inside the Mow loop. From onedinensional shock-tube theory, the peak amplitude of the initial pressure wate $\left(P_{1}\right)$ en be approximilted by the following insplicit expression:

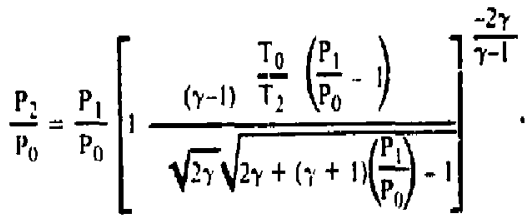

where $\mathrm{P}=$ pressure.

$\mathrm{T}=$ temperature.

$\gamma=$ ratio of specific heals.

subscript $0=$ al system conditions,

$1=$ for the pressure wave,

$2=$ after heat addition.

Cinder optrithing conditions $\left(2 \mathrm{~atm}, 25^{\circ} \mathrm{C}\right.$. and an energy ingut of $45 \mathrm{~J}$, gl. these equations predict reilk implitude of the pressure wille. corrected for duct ared expilnsion. all 12 k.P.it. This vallue correspondis to a measured value of $15 \mathrm{kP}$ il or a peak sound pressure level of $\mathrm{I} 80 \mathrm{~dB}$. The wase will decaly from this lerel, because of the viseosity and thermil conductive properties of the giss and duci germetry

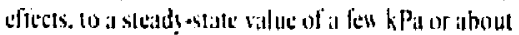
$160 \mathrm{~dB}$.

A these acoussit: levels, the pressuse fuctudtions degrade the laser oulpul power by apparently reducing the uniformity of the gas breakdown voltage in the electric-discharge region. Wo overcome this problem by adding an acoustic altenuator or muffiter into the fow system. The attenuator convert the nighly organized structure of the pressure waves into uncoordinated rundom motions of thermal vibration. This can be accomplished by replacing the hard duct walls with a porous stieet which allows the pressure waves to be iransmitled through the small passages in the muterial there viscous effects convert them into thermil energy. The muifler must also hilve a low through-flow pressure loss, lrom a system efficiency viewpoinl.

The CCTB has a single arcoustic mufnter section that is close-coupled to the downstream side of the laser head. It is a rectangular cross-section duct that houses two ressistive sidewill absorhers with bucking volume The 1 wo sidewall plates are $520 \cdot \mathrm{mm}$ wide and $247 \mathrm{~mm}$ in the fow direction. The duce height is
$30 \mathrm{~mm}$, with a backing depth of $14 \mathrm{~mm}$. This corresponds to a muffer length of $8 \mathrm{~h}$ (where $\mathrm{h}$ is the duct height) and a backing depth of $0.5 \mathrm{~h}$. The only source of through-flow pressure loss for this duct section is skin friction. The acouslic resistive material used is a nickel-felt metal. This material was selected because of its chemical stability with the halogen gisses used. The acoustic flow resistince (impedarce) of the felt metal is 68 cos ray!s. This value was selected to be a close match to the characteristic impedance of the system gas, which is $\mathbf{5 3} \mathrm{cgs}$ rayls. The reduetion of a pressure wave transmilted through the muffler has been measured to be $20 \mathrm{~dB}$, but further work must be done to reduce the steadystate sound-pressure level in the electrode segion which remains high. The addition of the murfer has resulted in a reluning of the acoustic characleristics of the flow loop. Some changes in the laser performance, which can be partially attributed to the muffler. are the reduction of the extreme sensitivity in the nulput power at specific values of the pulse repelition Irequency (PRF). and a removal of the alverage power roll-off observed for PRFs in the 300-to $-500-\mathrm{Hz}$ range. The outpul power is non a linear function of PRF, with a maximum value of $55 \mathrm{~W}$.

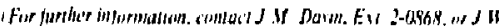

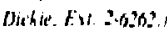

\section{Design of the Mars Experiment to Prove Economical Enrichment of Uranium}

The Mars experiment is part of the ongoing Atomic Vapor Litser lsotope Separatio i (AVLIS) program in which we are altempling to econimically enrich uranium for nuclear power plant application.

The process consisss of saporizing uranium in a vicuum furnace using electron-beam (e-beam) guns as the beating source. The vapor flows through an extractor process section where the 'י-U atoms alre ionized in a tuned laser heam. The product and tails aic collected individually in a now cycle tomputible with a plant's operation.

The physics process thas heen demonstraled and the Mars project is our first attempt at a liegescale system that will serve as a major subsyitem integration test facility. 
Figure 16 shows the Mars experinient module. The vessel conliguration consists of thret 5.5-fidiam stainless steel cylindrical chambers of singlewall construction. The vessel arrungement is serial. Two smaller saltellite vessels striulde the center source vessel. These satellite chambers contilin the ontues for foiding the laser beam through the center chunger. The center or source chamber contains a copper hearth and e-beam gun asicmblits, ext ractop. background collector. and protisions for uranium feeding and anterial output. The threttunk concept gives us the ability to isolate the optical components during vaporizer slitrup and al so mininizes the risk of optics comtanination durme maintenance and routine sleanup.

The approximalely 14-fi-long center source vessel opens along al horifontaj separating plane. This concepl permits operational aecess to both the source and oppics vessels for midintenante and system alignment and provides stithle strulural support for the three ubsystems. Center sersid opening is done by vertically faising the uppor lank half which is supported by four ball-drive strews und is guided by a reelangular supporl frome. Lid aclivation is accomplished from a locil control panel in the experiment bay. The lipht tuntiol connections are uniatched, and the bellows Mange assemblies are compressed to provide the necessans clearance before lifting the main lid. Sxuling acrass the horizontal hanet is accomplished with Iwo I 4 irt.-diam Viton-A O-ring seals. The upper haif or the source vesset contains two 30-1n. oforings thes provide the laser interface with the salellate vinels. Two 30-in.-diam sliding-gate ratues isolate the itrec vessels.

In,ernal cooling for the source vessel is accuinplished by contoured heat-exchanger panels (Fig. 17). The overlapping panel installation provides the necessury $x$-ruy shielding arsoss the horizontal flange-separating joint and facilitates cleanup. These panels line the uppis hall of the vessel, including end domes, and extend is in. into the lower section where they interface with horizontal panels that terminate at the source. The panel

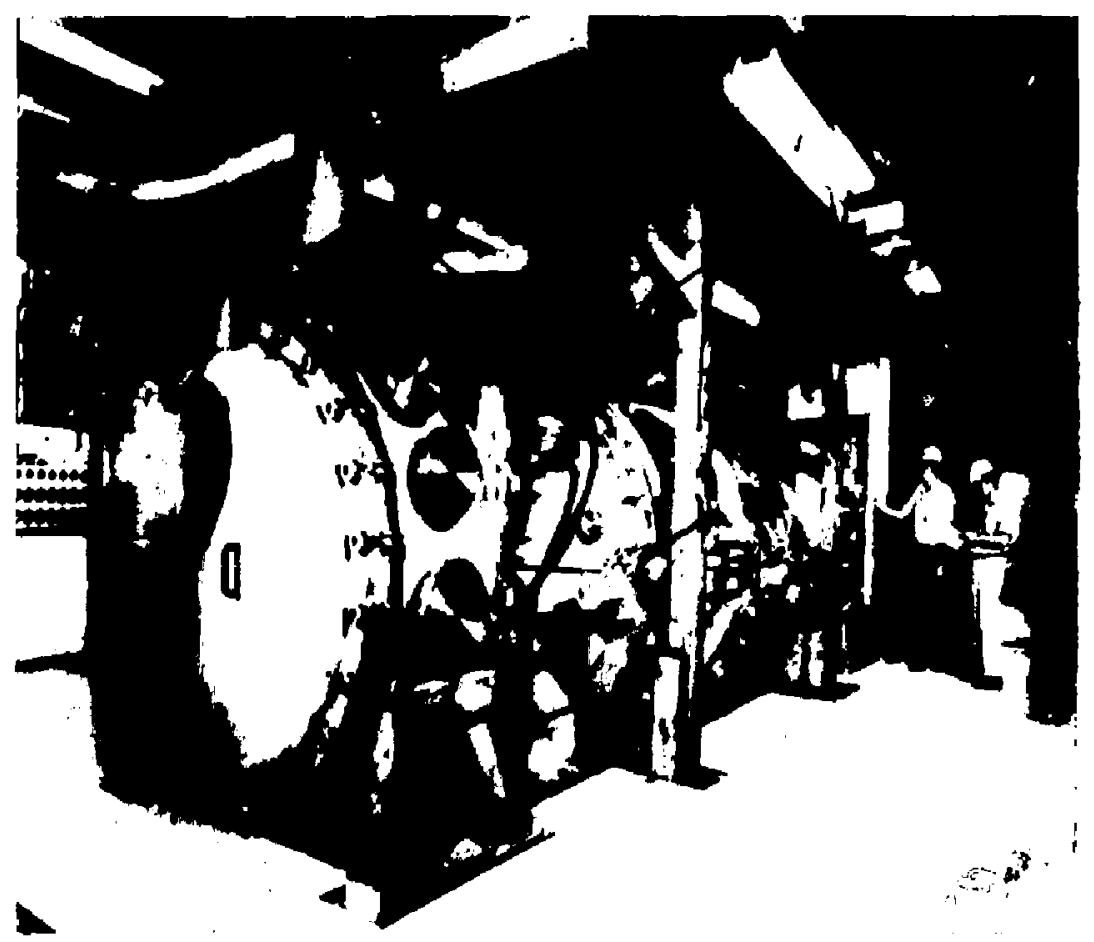

FIC. 16. Theciectamber Mlars iacuum irsecl. 


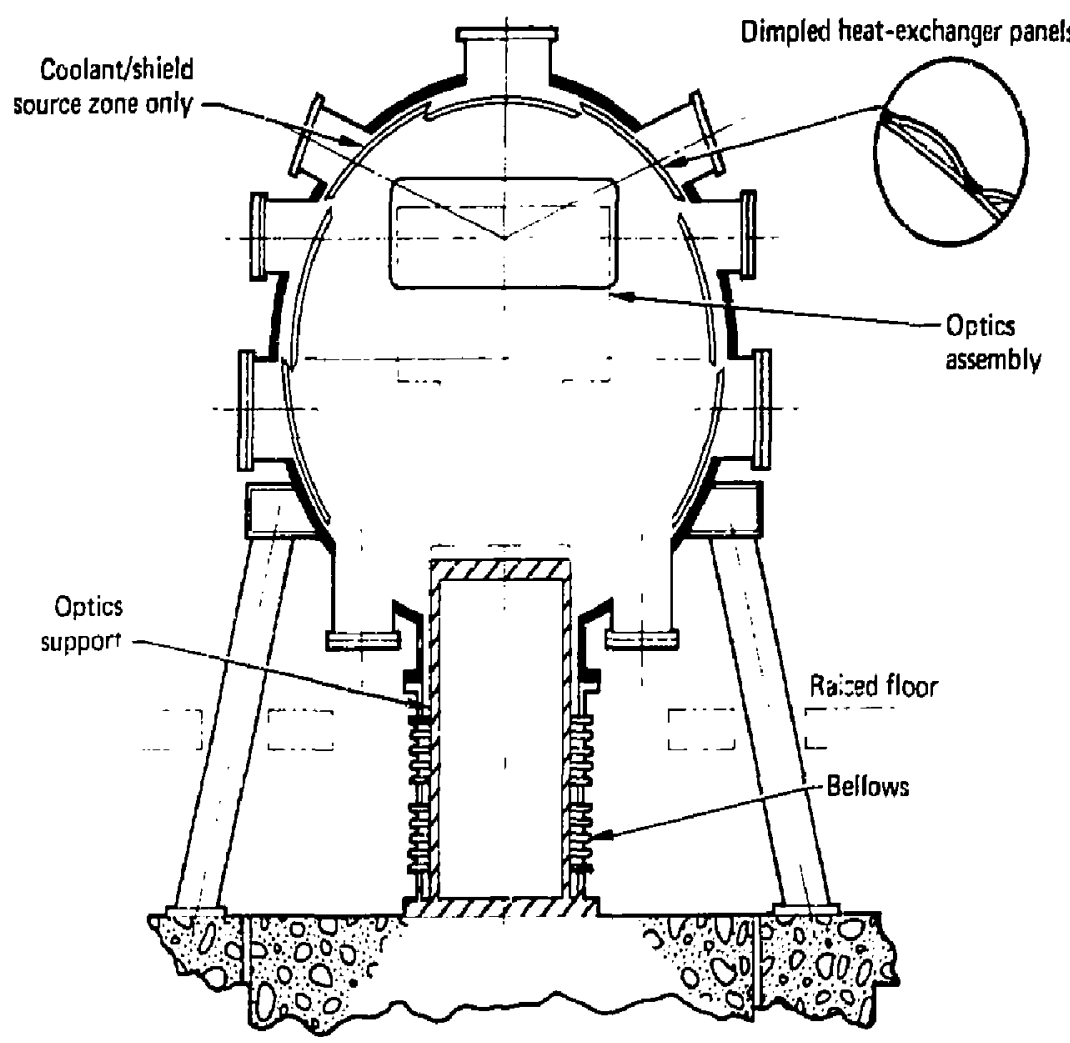

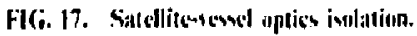

soncept is a cost-uffectist means of prowiding a culd-usill cosicl without constructing a double-wall iencil

lhe knet hatf of the main censel is lifuls

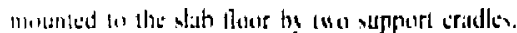

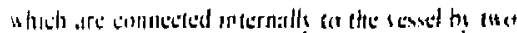

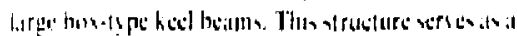

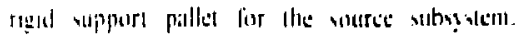

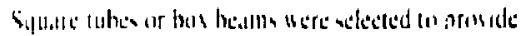

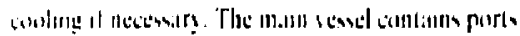

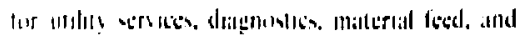

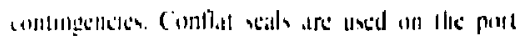
intiecs.

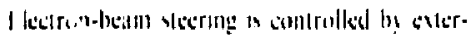

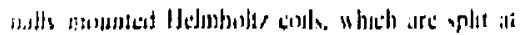

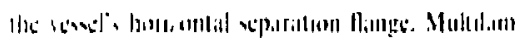

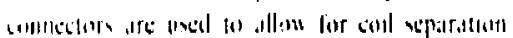

The uppor cessd lid in illịned daring thosing by tapered guide pins logitsed in the lower hinges. Theos

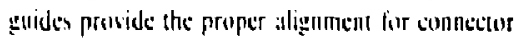

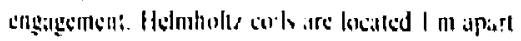
ores inc nource.

Iach sicellite upeces andel is supported by four canted leses belled directly an the slagh flowe. The tend

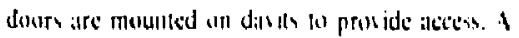
ingle pedtabil of IS-in, diatm. holed lo the anertual bane hested helow the uplic's tink. entends into the rexsl through a bollom port. The pedestal is atcached a the senet by a metal bedlows section. This

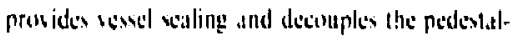
munuled aplice froll lank deflectoms ant

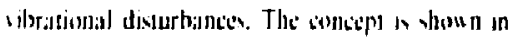
1!̣. 17. 


\section{Vacuma Pumping System}

The multiple-vessel vacuum system operates in the $10^{-5}$ Torr range. The system provides roughingand high-yacuum pumpdowin times of approximately $2 \mathrm{~h}$. System sizing was based on scaling existing facilities with a provision for additional louding from graphile components. A single 35-in. oil-diffusion pump (DP) provides 15000 -liter/s pumping speed at the inlet to the main chamber. The satellite optics vessels are pumped itrough bypass connections from the main vessel. Hecause of cost, a single DP system was selected rather than pumps for each satellite. However, the baseline system is adaptable to separate DPs since the backing system is sized for this contingency. The system can rough or hard pump any of the three vessels serially or simultaneously. For satellite-chamber maintenance, the main chamber can be held at vacuum while is satellite is brought to atmospheric pressure. then selurned to operational status. The sustenı contains optically tight cryogenic baffling in the muin- and fore-pumping lines 10 protect the optiss from oil backstreaming.

\section{Heat-Fachanger Puniping Sịstem}

The unhs, stems in the Mars man chamber tequaring cololsting water arte as follows: cuppor hearth.

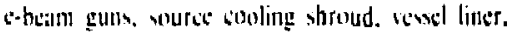
kect-huim structure. and diagnoslic prohes. The

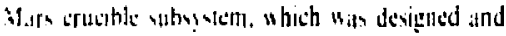

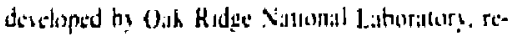

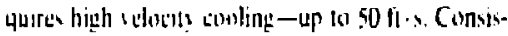

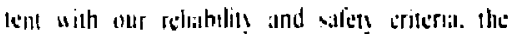

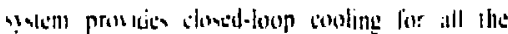

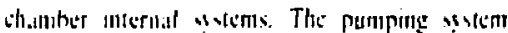

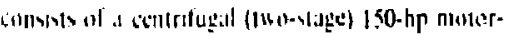

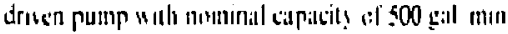

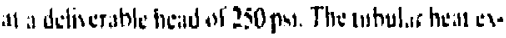

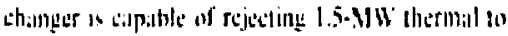

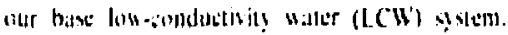

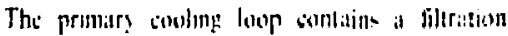
hypass pumn and promision fier shembical witts

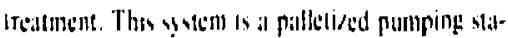

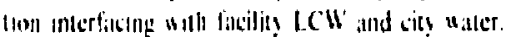

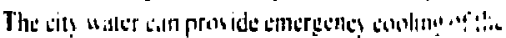

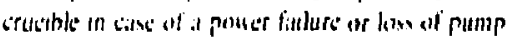
ritsenurt.

\section{I entilation Sivivm}

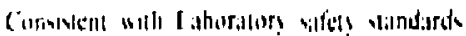

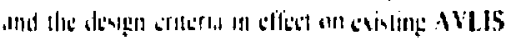

facilities, the Mars system contisins a negative air 5ystem in the vessel 10 prevent inhalation of uranium purlicles and to provide titecl containment. The ventilation system will maintain an airfuce velocity of $150 \mathrm{ft} / \mathrm{min}$ across the open areas of the ressel system.

\section{System Inregration}

The Mars experiment is currently on schedule. Low power e-beam gun tests are completed and uranium handling and vuporization began in midFebruary 1981. The Mars project team successfully completed Phase 1 facility activation and now the mechanical engineering leam is involved in design/enginecring of support diugnostics. feeder subssstems. and the logistics of at nattrial handling system. Full pouer operation is anticipated by July 1981.

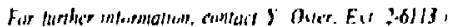

\section{Discharge-Healed Copper Vapor Laser Heat Shields}

The heall shictd region of at longitudinal discharge. discharge-thealed copper vapor laser (DHCVL), which is shoun in Fie. 18. is critical to werall laser performance. The DHCVL utliess the Waste heit generasted in an inser gils (and copper

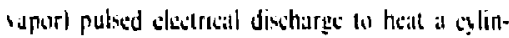
dritiol plasmla lube (1) a high operionng temperuturc $11400101600^{\circ} \mathrm{C}$. It the rilmte timt thls clettrieal disctiarge mes proside the copper illam popul:ation mersien required lor basing atctum.

The hish ontrattenal temperature as required

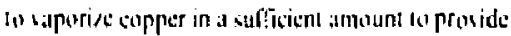

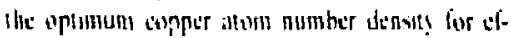

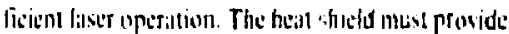
only enough ther mill insulation to yeld the plasnia tubs tenuperatture for optimial fuer aptralion within the comstrants of inpul porer telectric distharge wiste hettl. sopper illom nember densily. output fower. and anvial temperature prolile. Because of howe reyuirentents, detailed thermal analysis capabulity is necessiory wo botter understand

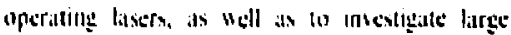
teconsetries forr liater staling sidudies.

In the desclopment of DHC V'L. three dif-

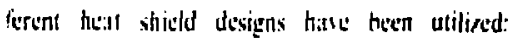
metiallis, hybrid nonmitallis, and nommetallic. 


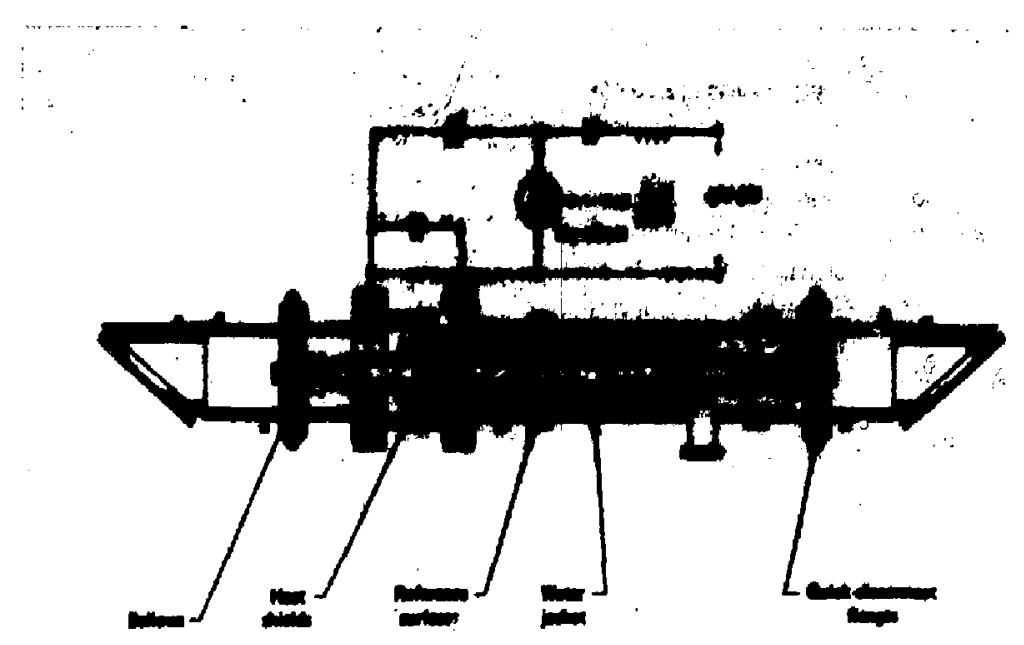

FIC. 18. Copper sapor laser.

Because of the high lemperatures involved, the metallic thermat radiation shicld was the first one used [Fig 19(a)]. II was fabricaled into a cylinder of sprail-weund molybdenum foil (<4.8+cm-diam over a 3.2-tm-diam plasmu tuhe) separated by a lirecemesh tungeten sereen and operalted in il vacuum. The vacuun essentially eliminated radial gaseous conduction and convection losists. the screen minimized radial melallic conlact (conduction) losses. and the molybdenum foil layers minimired thermal radiation losses. Thic nectallic heal shicld uraps must be insialled so there is no conlat with the alumina plasmia tuhe to avoid diclectric breakdown of the alumine because of the differenct belucen the capacitively coupled heat shiseld voltage and the plasma voltage. However, beasuse of their rudial compactinesis, metillic heat shiclds afe the primary ty pess utilied ior the majority of small-hore DHCVLs in operation.

The second type of DHCVL heat shield developed was the hybrid nonmetallic design shown in Fig. 19(b). This heal shield configuration was developed to provide a package that was as radially compact as the metallic heat shields, but that was consiructed of more readily available and less costly components. This was accomplished by utilizing a combination of fibrous alumina and zirconia cylinders surrounded by several spiral wrapped layers of molybdenum and nickel foils separated by alumina cement and operated in a vacuum. The fibrous ceramics were not of sufficient thermal efficiency for this smail diameter to eliminate the use of metal foil wraps altogether. However, a significant reduction in the molybdenum foil usage and a total eliminution of the tungsten screen was realized. Also. because the metal foil layers were displaced a muci: grealer distance from the plasma tube in this design. problems associated with dielectric breakdown of the alumina plasma tube werc also reduced.

The third type of he:st shicld developed for DHCVL operation is one construeled entirely of a fibrous alumina ceramic [sec Fig. 19(c)]. Beciusc the nonmetillic heil shield material has an effective thermat conducivity greater than that of a metallic or hybrid nonmetallic heal shicld, this construction is utilized primarily with large-bore copper lasers where there is more waste beal arailible and the cylindrical geometry is more favorable. Howerer. nonmetallic heal shiclds have been utiliaed for small-bure copper lasers with increased diameler vacuum jackets (heat shield diameter $<6.3 \mathrm{~cm}$ ). Beedusc of the stetrical insulating properties of the fibrous aluminil, use of the nonmetallic heat shields essentially climinates plasma tuhs failure due to dielectric breakdown. 


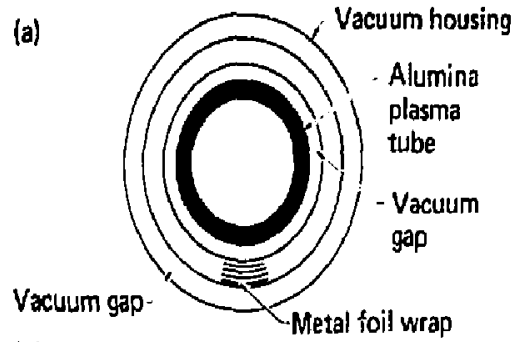

(b)

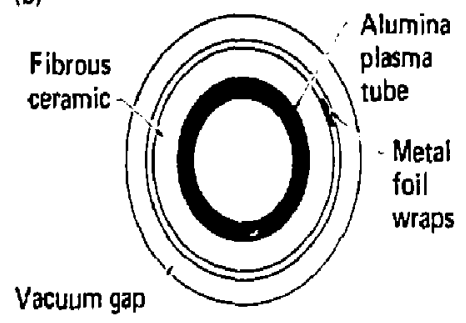

(c)

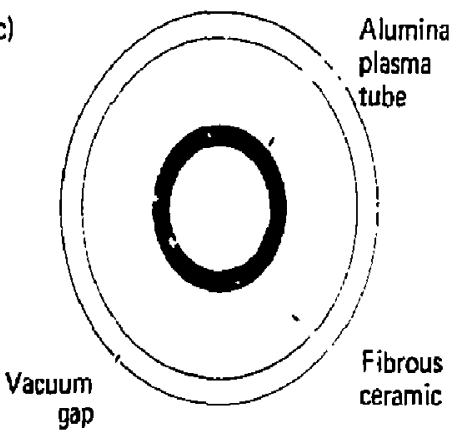

FIG. 19. (a) Cylindrical-metallic, (b) hybridnommetallic, and (c) nommetallic heat-shield arrangemetis for small-bore DHCVL operation.

The cipatility to prediet the thermal chatrite-

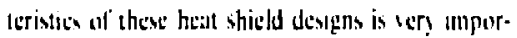
lant to DHCVI. oneration. Computer cilculatilusial

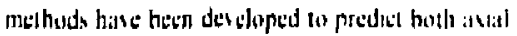
and radial cemperature profiles of cindindreat cup.

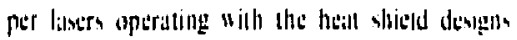

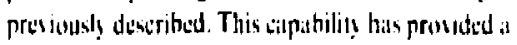

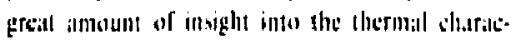
teristists of holl aperating lasers and proponed larese-bere listors lor stialing limit sudsca.

Figure 20 prestils cilliulited perbormalisc

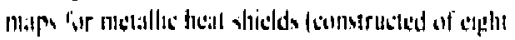

melal foil wraps) necessary for a 2.5 -cm-diam copper laser. The in formation is presented in a manner such that the known (or projected) waste heat charucteristics of the laser can he combined with the enissive properties of the metal fail layers to de'ermine the maximum (center) plasma tube temperature that will be achieved. By determining similar gruphs for heat shiclds with different numbers of lotal melal wraps, the number of wraps necessary to achieve a particular maximum plusma iube eenperature can be delermined. Once a particular heal shield assembly and operating conditions have hecn chosen. the avial and radial temperinture profiles can be calculattod.

Figure 21 presents al comparison berisen the measured and calculated axsal temperature profile of a largh-tyse $(7.3-\mathrm{cm}$-diam) DHCVL operating "sith a nonmetallic heal shield. The operating conditions and calculation paramuters are listed in the figure for reference. The themal conductivity utilized as al quadratic surse fir lo anformation given hy the milnufacturer of the heil shicld mialerial. The heall Mur IDHK 'L wiste heal) used in the cilculatllon 11 as adjusted for best ilegremienl with the

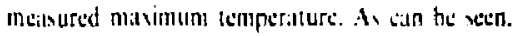

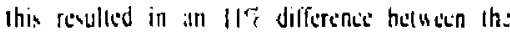

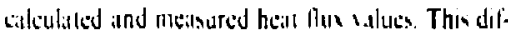

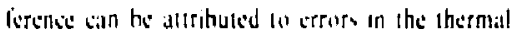
conductu th wilied.

The primary interes in the cimpariven of

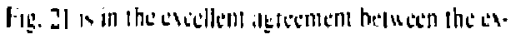

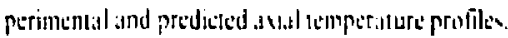

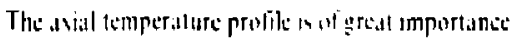

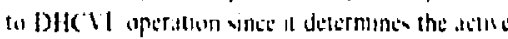

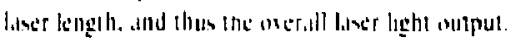

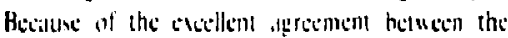

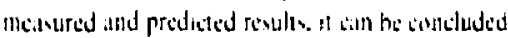

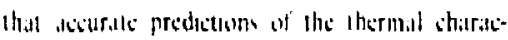

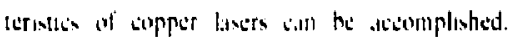

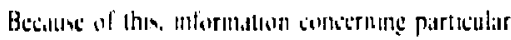

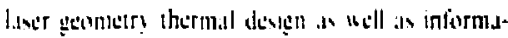

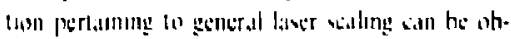

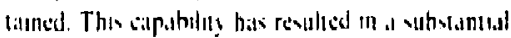

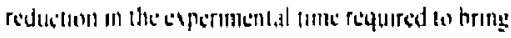
a conceptusl DHCW mo lidl optratumal cilfohililis

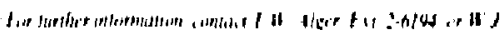

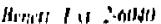



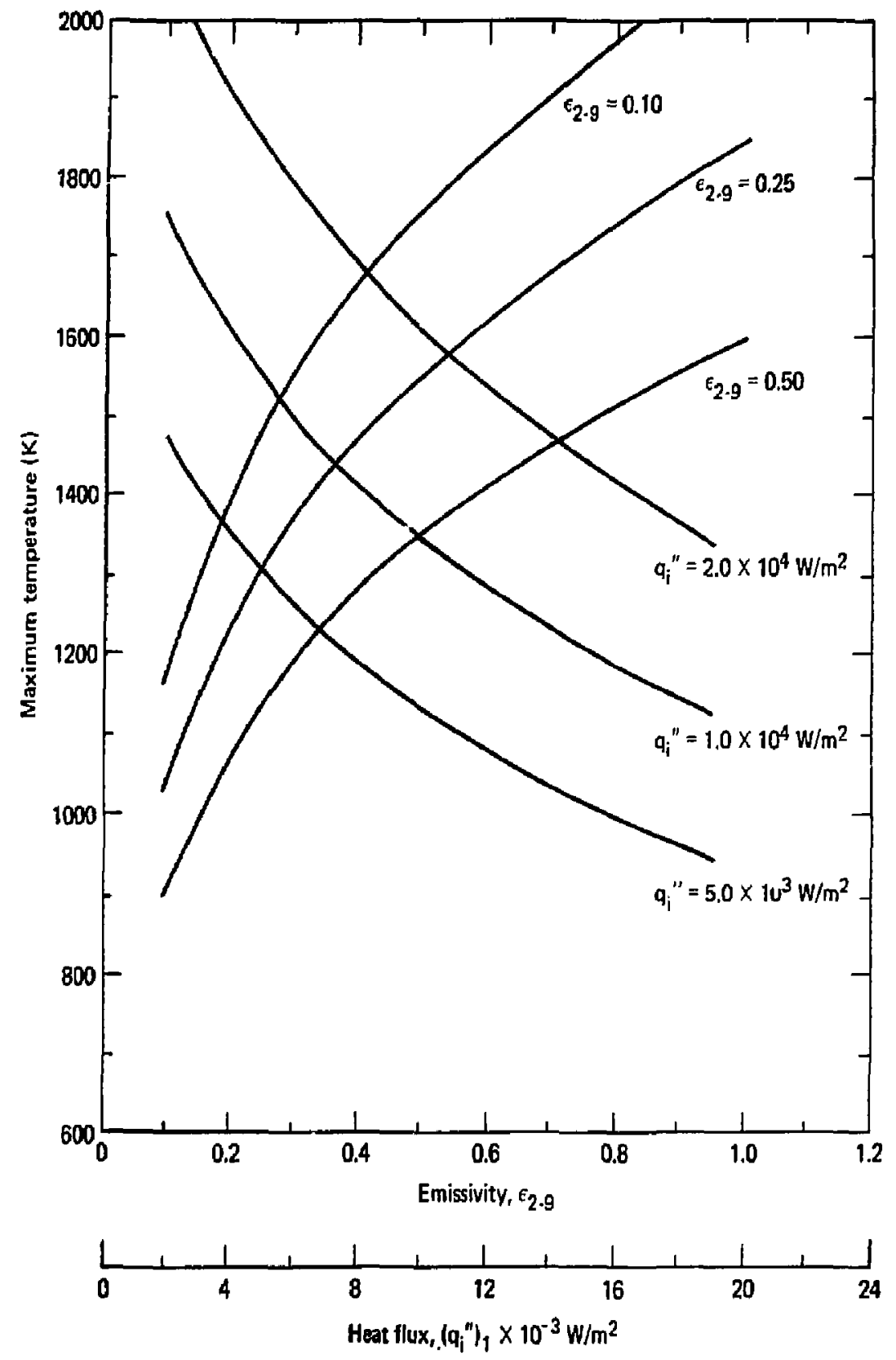

FIC. 20. Plasun tube (2.5-en diam) center temperature as a function of the applicd heat flus or the metal foil emissivity for a metallic hent shiedd with eight foil wraps. 


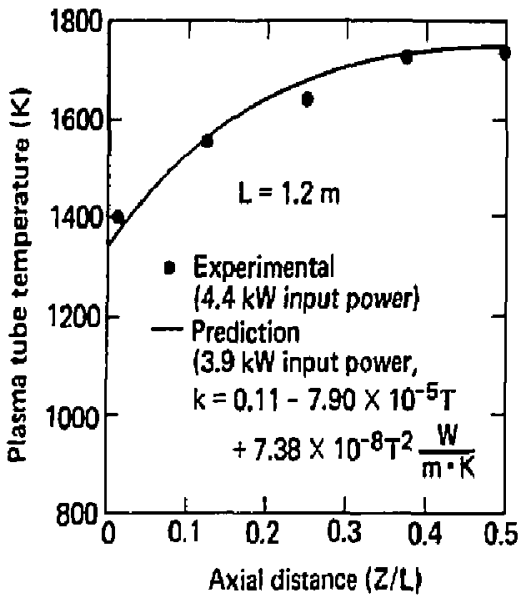

FJC; 2l. Fxperimcstal and compuled plasma ube (7.3-cm diam) axial tomperature profile comparison.
I. Laser Program Amnual Report 1979, Lawrence Livermore National Laboratory, Livermore, CA, Rept. UCRL-50021-79, pp. 4-38 to 4.44.

2. D. T. Allwood, D. W. Sweency, J. M. Allerbach, and P. H. Y. Lee, Phys. Rev. Lett. 40, 184 (1978).

3. D. W. Sweeney, J. Opl. Soc. Am. 64, 559 (1974).

4. D. W. Sweeney, D. T. Attwood, and L. W. Colemian, Appl. Opl. 15, 1126 (1976).

5. E. E. Pierce, Appl. Opt. 19.6 (1980).

6. H. T. Powell and B. R. Schleicher, J. Chem. Phys. 73, 5059 (1980).

7. J. R. Murray and C. K. Rhodes, J. Appl. Phys. 47, 5041 (1976).

8. G. Black. R. L. Sharpless, T. G. Slanger, and D. C. Lorents, J. Chem. Phys. 62, 4266 (1975).

9. G. Black, R. L. Sharpless, T. G. Slanger, and D. C. Lorents, J. Chem. Phjs. 62, 4274 (1975).

10. G. Black, R. L. Sharpless, and T. G. Slanger. J. Chem. Phys. 64, 3985 (1976). 


\section{ENGINEERING SCIENCES DIVISION}

The Engineering Sciences Division (ESD) provides conplete technicul services for materials characterizalion. cngineering messuruments, nondestructive cvaluation, und mechanical systems design and evaluation. The Division has more that 20 separate laboratories and racilities that are organized into sections responsible for specific lechnology areus.

The Materials Test and Evaluation Scetion provides nechanisal tesling, such as ASTM standard tests and special tests tailored to individual customer requirements. Dewelopment is a majur tifort in the fields of acoustic emtission. fracture mechaniss. high-ralte response. and composisite malterials evaluation.

The Frigincering Medsurthents Section is ongaged in work ranging lrom calibration of a single transducer to fielding complece measuren munls sistcrns. Service for the calihration and in. stullation of Iransducers and accelerometiess is jrailable.

The Nondestructive Evaluation Section provides quality-ussurance services and engineering inspeclion for LLNL programs. Nondestructive evaluation is done with neutron. $x$-ray and gamma source radiograpby, ultrasonics, eddy current, dye penetrant, magnetic purticle, and holograghic techniques. Precision radiation gaging is available.

The Engineering Design Scetion designn and Rabrisules hardwarc to support the Chemisiry and Halcrial Science Deparment. the Earth Scientes Dirision. and ESD itstels. A majnr effort is support a) the tritialn Facility operation.

The Life Sctences Group provides mechanicall enginuering surpport for Biomed and Environmental Research. Jiladrds control, and Tovic Wastc Management program. Specific examples such as the cetl surles ill Biomed, persomntel dosimetry equipment in Harards Conlrol, and slorage and/or hurial conlajners for toxic uastes, gljes some idta of the varied reyuirtmeris in these are:1s.

The LLNL Plutonium Facility is managed by the Chemistry and Materials Science Department with operational support provided in part by ESD. The Plutonium Engineering Section in ESD provides enginecring design, fabrication, and testing services for the Facility and its users.

The Trunsportation and Macelanical Energy Storage Section provides restarch, technical aster. ment, and planning support for DOE programs in trunsportation systems and energy storage. Examples of mechunical storuge -chnology under consideration include flywheels, clastically deformed polymers, and compressed fluids. A major transportution project is the sludy of roadway-powered electric vehiste systems.

(For further information, consaat R. W. Werne, Ext. 28360.)

\section{Developing a Facility for Fatigue and Fracture Testing of Stainless Steel Weldments and Base Metrl at Liquid Helium Temperatures}

We have designed a mechanical test facility to evalualte fatiguc and fracture toughness properties of stainless stecl welóments and base metal at liquid helium temperatures. This is a joint effort between the Engineering Stitnces and Magnetie Fusion Enginetring Divisions 10 study the cryogenic hethatior of materials selected for the siructural cases of the MFTF-B magnet system.

Fabrication of thesc structures requires "stding thick settions. For this reason, along with the higher stresses produced from the increased opurating mlensity of mugnetic fields at $4 \mathrm{~K}$, we are conetrned ahout the structuril integrity of hoth "selds and base metal.

In planning the test facilits. we had sereral devign considerations. With the higher cost of liquid helium. " c placed high priorits on minimizing its usige. Wis considered the natural and forced convetion of liyuid helium and the heul-tonduction properties of the lest fixture when selecting materials and designing the crsogenic load train. Hollow compression columns and al modified pirot plate were specially designed to reduce the mass of stiminges stet exposed to liquid helium. We "sere also concerned with the facility cost and ease of uperation, i.c., access to specimen grips and disposal of liquid helium and liquid nitragen. N'e therefure deceded on a mechanical testing sastem list machint with a trosshead-mounted actuator which allows the entire eryogenic load train to tw lowered into the liquid helium Dewar (Fig. I). Special ruhbur and sinthane rings provide thermal 

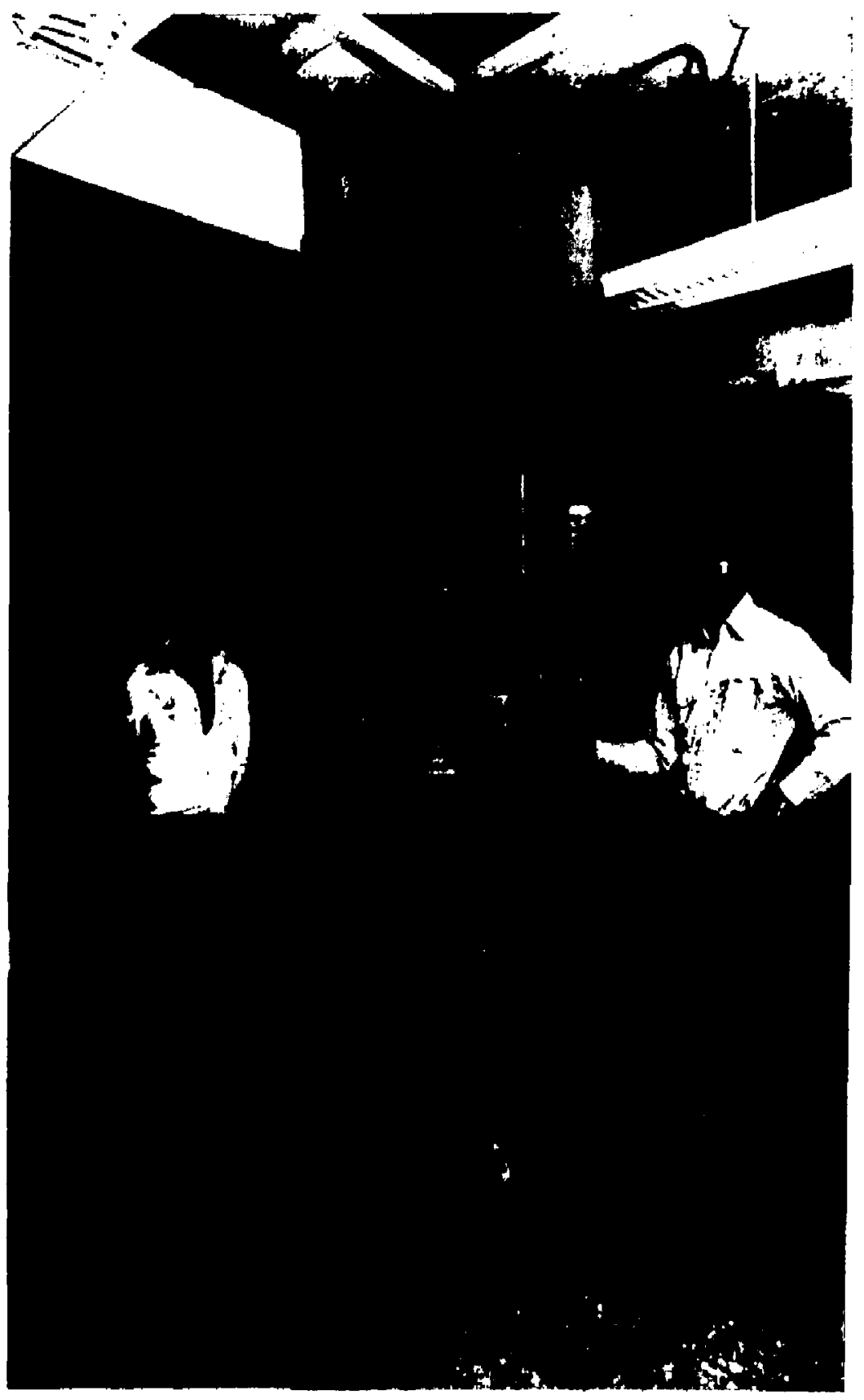

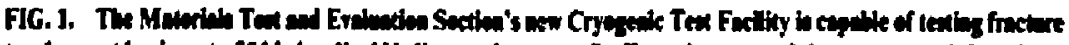

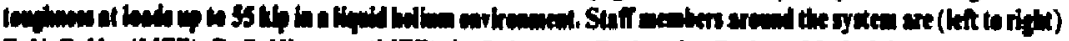

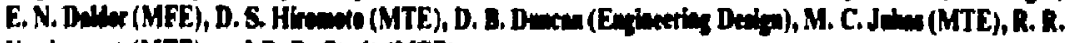
Vumbrent (MTE), and R. D. Strek (MTE).

59 
insulation of the load train from the actuator and load frame.

We expect to begin a fracture mechanics lest program in the near future. Our immediate testing witl include J-integral evaluation; however, we also plan fatigue crack growth studies and tensile testing.

(for fwither informalion, confact M. C. Jwhs, ExI, 3-12SA, D. B. Duscos, ExI. 2-9463, or R. D. Sureil, ExI. 2-1045.)

\section{Flash Radiography with}

\section{a 2.3-MeV Febetron}

Over the past year the nush radiography capability of the Nondestructive Evaluation Section (NDE) has been enhanced with the refurbishment of a Field Emission (now Hewlett-Packard) Febetron machine. The unit is on loan from the Laboratory's Y Program where it had been used as an electron beam source. Funding, which is through a reimbursable project on propellant sludies from the Chemistry Department, brought the unit out of storage and made possible its conversion for $x$-ray production. Byron Kitt of the NDE section has worked exiensively on refurbishing and operaling the unit.

Figure 2 shows the unit and its control console. The peak $x$-ray energy is $2.3 \mathrm{MeV}$ with a pulse width of $30 \mathrm{~ns}$. This short duration flash can stop the mction of very fast dynamic events. Figure 3 is a flash radiograph taken with this unit at Site 300 . A high velocity steel projectile strikes a large $(150-\mathrm{mm}$ diam by 100 -mm-thick) disk of propellent. The shock and deformation of the propellent are recorded by the radiograph. The radiographic information is used in the evaluation of propellent detonation characteristics.

(For further finformation, conracl R. H. Bossi, Ext. 7-013l.)

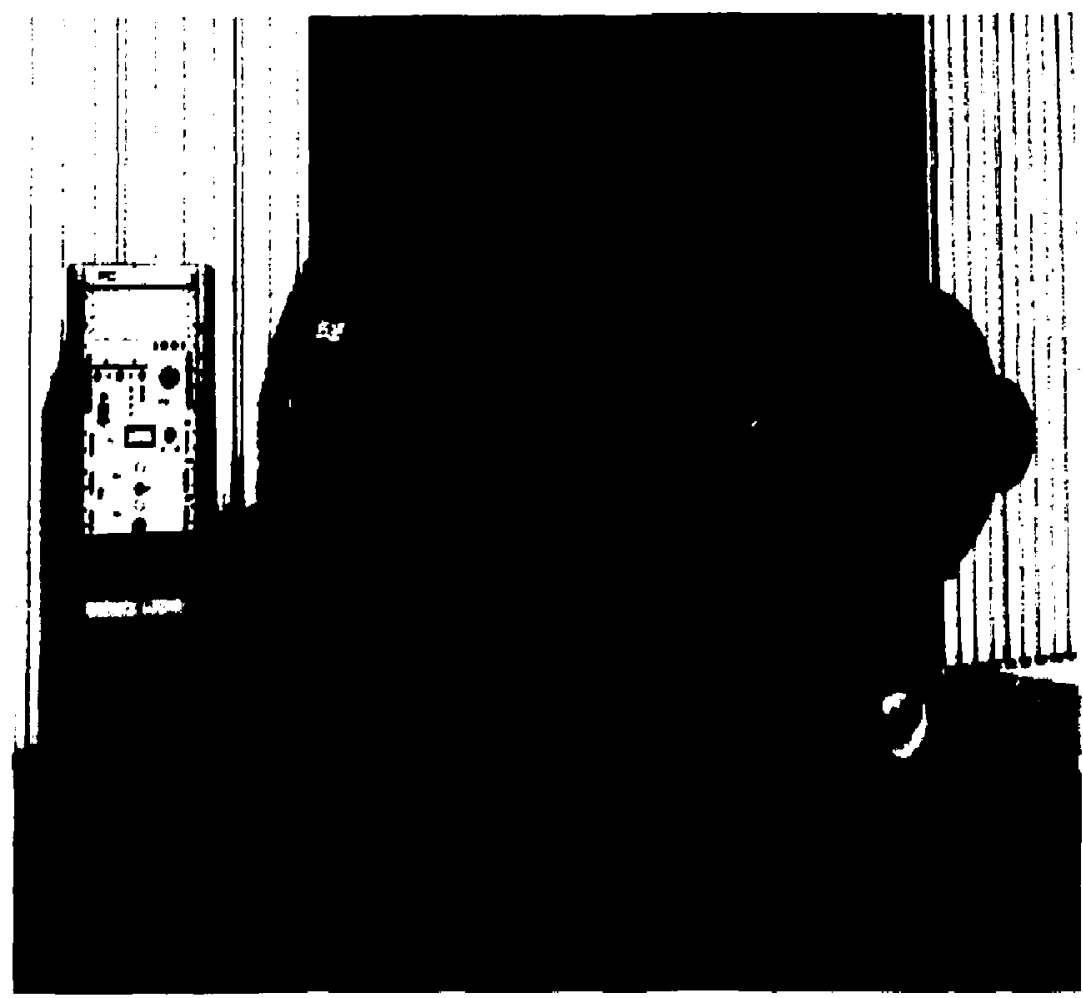

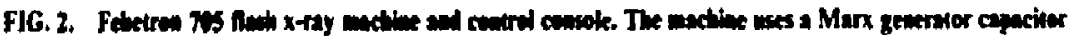

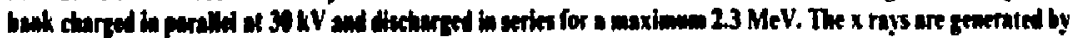

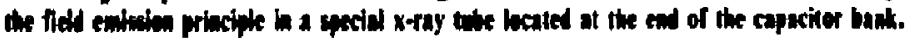




\section{Holographic Evaluation of Composite Structural Bulkheads}

Thermal stress holographic interferometry is being used for the nondestructive evaluation of compositc siructural bulkheads made of composite materials. Delamination, fiber breakage. and overall quility of the composite material is of interest. The holographic examination of the composite siructurial bulkhead is performed before hydrostatic testing. after a predetermined hydrostatic pressure test, and after the part has failed.

The thermal stress lesi can be performed in either in real-time or double-exposure holographic techrique. In the double-exposure method the lirst exposure of the composite struclural bulkhend is mude at ambient tempersture. The compesile structural bulkhead is then heated sith a heat lamp and monitored with a thermocouple 10 a maximum temperalure of $150^{\circ} \mathrm{F}$. The composite structural buikhead is then allowed to cool to $90^{\circ} \mathrm{F}$ and the second uxposure is made (ste Fig. 4).

This work is being performed is part of in nondestructive evaluation program to determine the best method to measure the quality of the composite domes after the hydroslatic proof test. Future holugraphic testing of composite structural bulkheads will include conlinued thermal stressing and the development of as hydrostutic lesting procedurt.

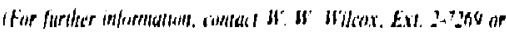

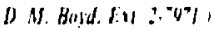

\section{The Use of Pulsed Light Sources to Characterize Materials}

When a pulse of light energy of surficient amplitude impinges upon a muterial. an stastic stress wave will he generated in that material. Several mechanisms account for this crfect. $A$ pulse of low unergy $(-0.10)$ J will produce a thermilly gentrated stress Have, whereils a high energy pulse $(\sim 15 \mathrm{~J})$ will penerate is stress gulse as a result of material vaporization and blow'off. In either ease the resulting stress wave cin he used to determine the material 's somic velucily, its colastic constanls, and to Jetecl flass in the malerial.

The parpose of this sesturch proje: has been 10 cxplore a variely of avialiable pulsed light swurees

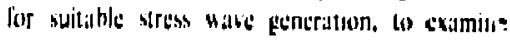

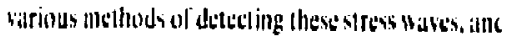

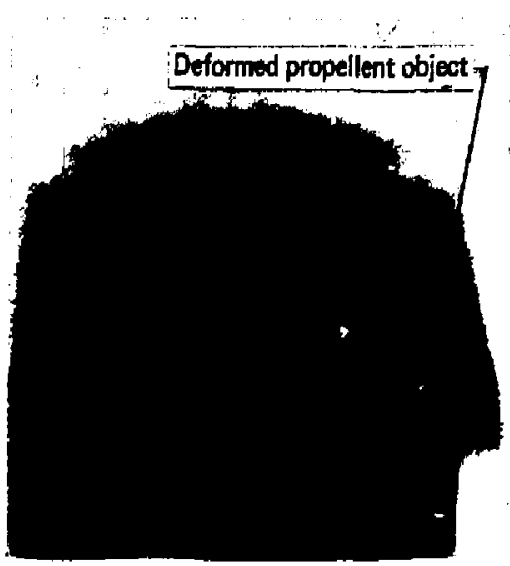

FIG. 3. Fien $x$-nay rellegrayly of a propellent of ject. The 100-hy-15\%-widien propellest olject is struck fros the left by a sted projectile 150 mon in dinecter. The projectlie is fired at the object from a 155-win Gath.

to apply the concept to materials chiaracterization in a nondestructive manner.

During the final quarter of this liscal year. primary emphasis was placed on investigating techniques of water-immersior. testing using a Q-pulsed Nd-glass laser. Using fiber optic bundles, the laser energy could be easily directed to an immersed specimen for stress wave generation. Several secondary parameters were also explored, which included comparison of the responses of a variety of 1ransducers as well as investigating the potential of using displacement interferometry in conjunction with water immersion testing.

Several different experimental arrangements have been used in the water immersion lechniques.

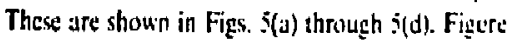
$S(a)$ shows the specimen plated in a glass-walled water tank, The energy from a Q-su itched laser is directed through the glass wall of the contuintr. through the water interface 10 the spicimen. Previous tests have shown that the angle of incidence of the incoming Jiser pulse to the spe imen is nol particularly critical for angles as great as $60^{\circ}$. This makes geometrically fexihle and thercfore estremely convenient detection of the resultunt lasergenerated stress wates with an immersed ulirasonic Iransducer.

The arrangement shown in Fig. s(b), whete the sensing to:nsducer is loceted behind the specineen. 

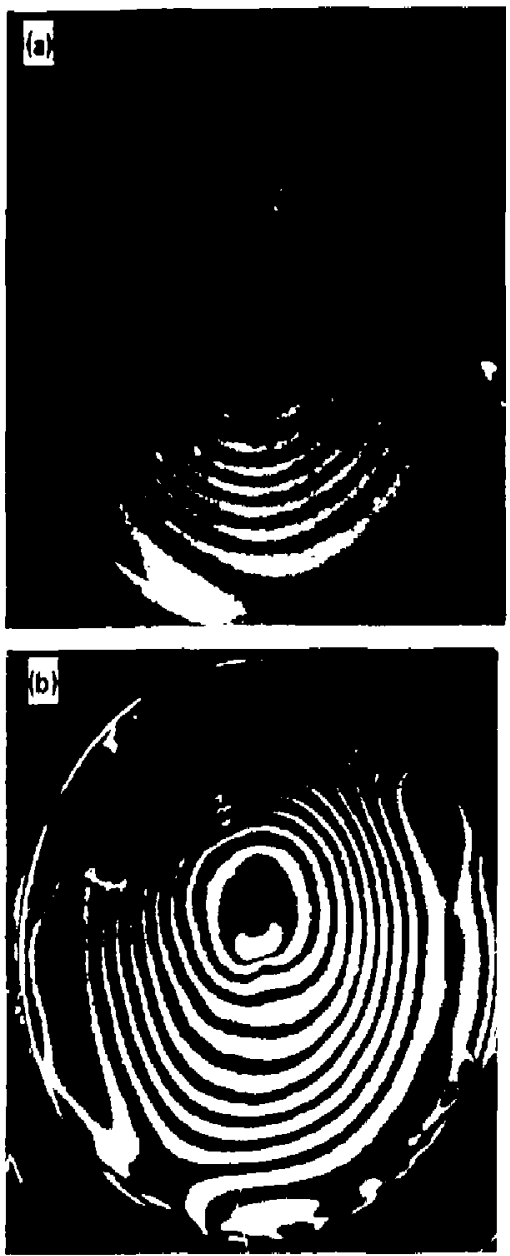

gast results smilar to those obtained usimg tioc

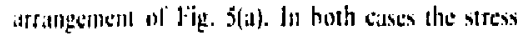
Natid tramsil tome coufd be atcurately determined and the specsimstrs sonic velocity talculated.

figure $5(\mathrm{c})$ shows the immersion testing scheme using a fiber optic bundle to direct the laser entrgy to the sample. The advantage of this technique is the ibslity to direct entergy to any part of the specimen. The sample may also be oriented in a masner which is most convenient for recording the fusulting siress wave with either an ultrasonic Iranducer or with displacement interferometry.

Jil I.ge. S(d) the tombined une of liher aptics and dosplatement interforometry is depteded. This

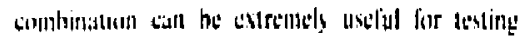

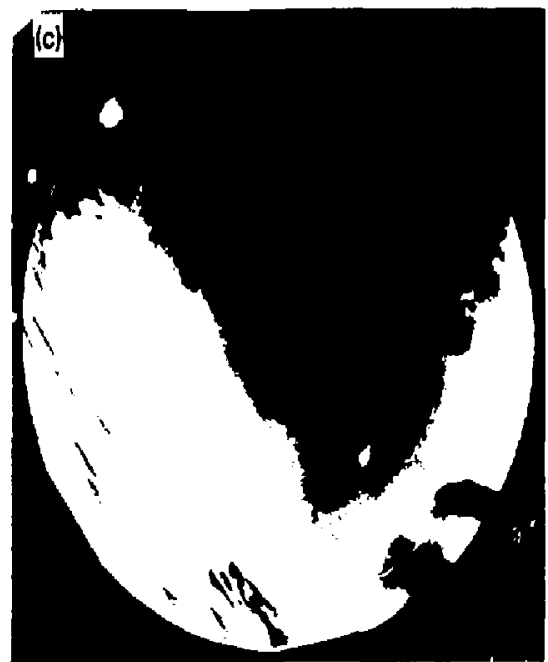

FIG.4, Three holograms of a composite structural bulkhead: (2) shows the part after thermal stressing but before hydrostatic testing. The "fish tail" fringe pattern near the upper left of the part iadicates 1 possible delamination site. (b) shows spurions fringe patterns near the edge in the upper left and lower right portions of the composite structural bulkhead, in dicating abnormal surface movement. (c) shows that the composite structural bulkhead failed close to areas depicted by the spurious fringe paiterns in (b).

componcuts with complicalted geometrics or in hasardous toviromments.

An evaluation of the response of a variety of transducers was mide in order to determine which Iransducer or transducers were most suitable for detecting the laser-generaled stress waves and for flaw delection. Transducers evalualed included 0.5 . 1. 5. 10, and 26 MHz PZT (lead-zirconale-tilanate) and lithium sulfate transducers, one-dimensional strain lithium niobate transduzers, and quartz transducers.

It has previously been shown that the width of the stress pulse generated by in 30-ns laser pulse is on the order of 100 to $200 \mathrm{~ns}$ in most metals. Because of this the higher-frequency transducers proved to 


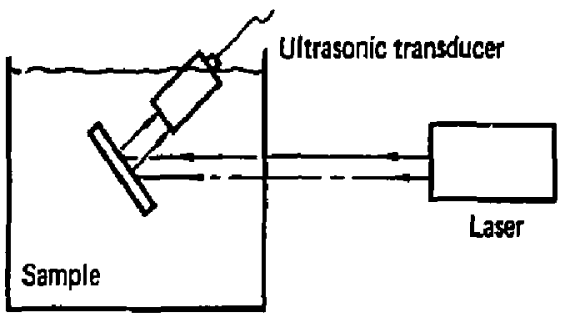

(a)
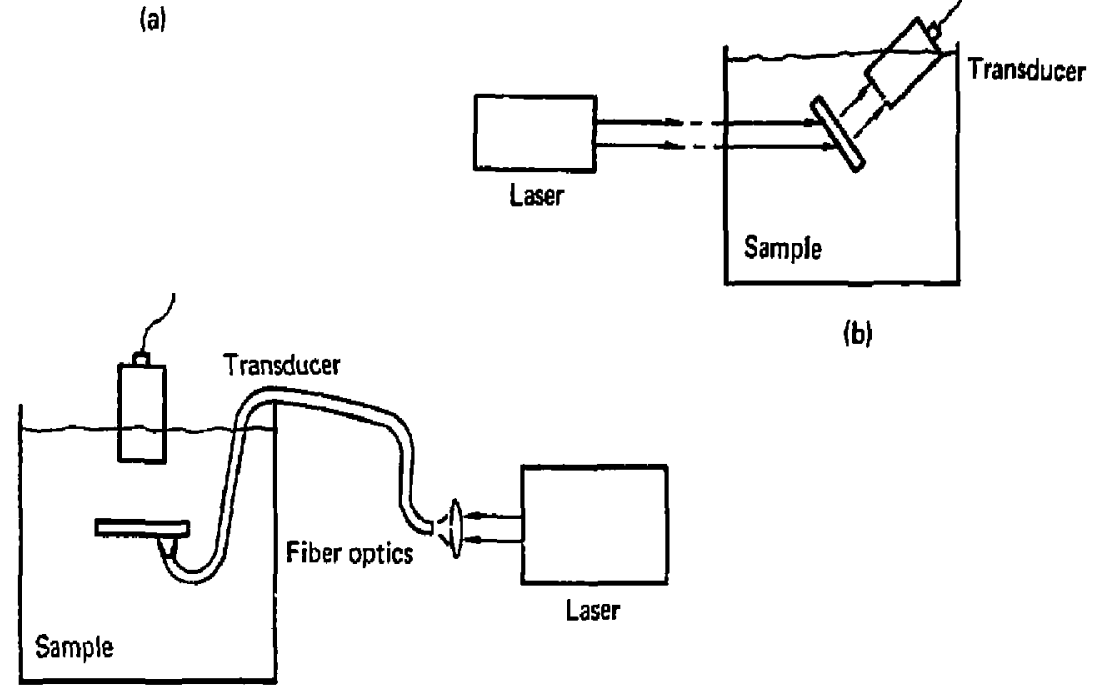

(b)

(c)

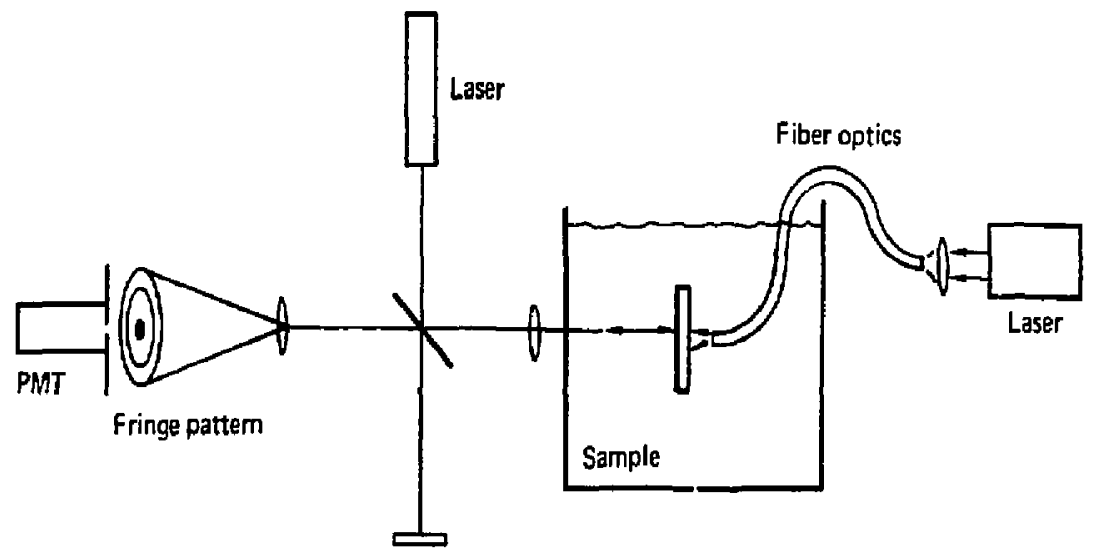

Ref. mirror

(d)

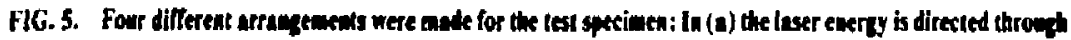

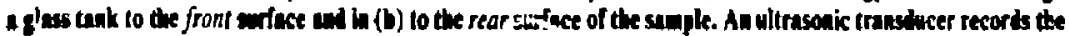

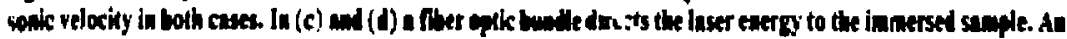

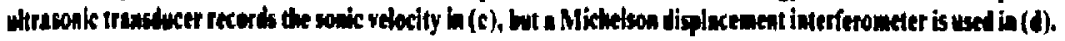


be more accurate in recoiding the stress wave arrival times and were also more suitable for haw delection. $A$ desirable feature of the piezoceramic Ifansduters is their high sensitivily when compured to that of the quirl. irinsducers. The quirty transducer is valuable for making actual struin medsurements. but is not suitable for flaw detection purposes.

The displatement inlerferemeler is the most versalite "Irinnducer" lor use in sonic velocity meisurements. ff tun be usted for flan decection ils ustl. but is unl! vallid is al quilititite nlteisuring

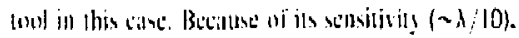
its potentiat for locating liaw of suhmillimeter si/c in very promising.

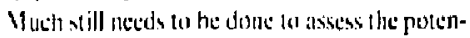

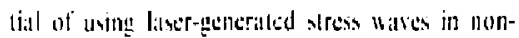

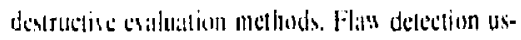
ing thin method hould be a stpattale study.

Materials characterization using pulsed ligh sources has been shown to be a viable technique when assesing somic velocilies. clastic constants, and for flas detection. Varrious detection techniques, which include picoceramic and quarte transducers as uell as displatement intererometry huse heen show to be useful and computible for detecting laser-gentraled stress waves. Suecessful thamiration of malerids to determine their propertics and characteristics and lo locale flaws in them hals hecls sarried oul in a nonrcillact and non. destructive manner. The protential remains high for further development ats a very useful NDE tool.

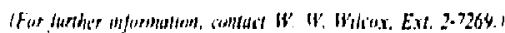

\section{Flywheel Energy Storage Systems for Use with Photovoltaic Power Sources}

The 1/twhel Eneres Storitge System (FESS) is imtended to enhantere the ballue and uility of smatl

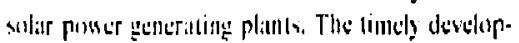

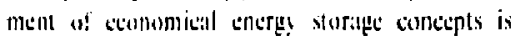

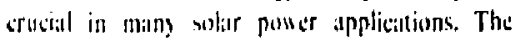

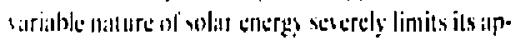

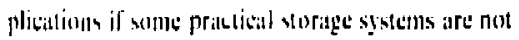

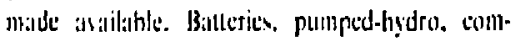
prosed air. therntal and mechanicil energy storipte

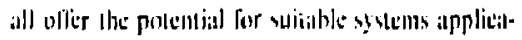

lions. Economic factors may filvor one system in a particular applicution and yel another in a diffur unt applicatlion. depending upon performance and cosi tharacteristics. Howeser, al present ikcuratte tost and performance characteristicy do not exist for emerging fuchnolugies. Neu designs with generous natreins of sifely halve not yel been demonstrated for inechanicil energ! storige systems. A FESS soncipl which could luald toward a practical

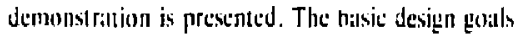
are summarised in Table 1.

Solar photovoluaic (PV) power systems prescolly being developed invariably use electric storage balteries when on-site energy slorage is required. Moreover, studies of fulure PV power systems assume continusd use of batterits for onsile sloragc, albeit with more advanced, eflicient, and inexpensive buttery designs. This predominance is due at least in part to the generally held conviction that no other on-site storage system can com. pete economically with balleries for PV usage. However, studies performed show that flywhed energy storuge can be techrically and exonomically competitive with sither present-dily or advanced slorage batueries if the nywheel slorage system is properly conligured. This conclusion was reached ufter comparing battery and flywhecl slorage in is

TABLE I. Principal design goals for the system.

\begin{tabular}{|c|c|}
\hline Parameter & Insign goals \\
\hline \multicolumn{2}{|l|}{ Filectricul interface (FESS) } \\
\hline linc-to-line voliage ( $)$ & Belun 220 (,7-phase) \\
\hline Freguency $\left(\mathbf{H}_{L}\right)$ & Belan finil \\
\hline Power in (kW) & +.10 \\
\hline \multicolumn{2}{|l|}{ l'ower out } \\
\hline Intumittent (5 min). $\mathrm{kM}$ & 6 \\
\hline \multicolumn{2}{|l|}{ Steady-s|ate $\{k|l|$} \\
\hline A vailgile cnergy (kH h) & 7.5 \\
\hline Fincrgy slored ( $k \mathrm{H} \cdot h$ ) & JII \\
\hline Rotor dentily $(I / \cdot h / l b)$ & 211 \\
\hline \multicolumn{2}{|l|}{ Ferey lasss } \\
\hline Notor I"it & 5.0 \\
\hline Cienerilor ( $T$ ) & 5.0 \\
\hline All other loses (ri, hr) & 11.5 \\
\hline J.ife expectancy (ą) & 2ll \\
\hline $\begin{array}{l}\text { (getis life minition foll } \\
\text { charge/dischurge (cyctes) }\end{array}$ & II) oxt \\
\hline
\end{tabular}


systems context, whereby' their influence on other subsystems (such as invurters) was determined.

The essence of this approach is to utilize the nywheel subsystem for mort than the energy slorage function. A PV power system usually requires an inverter to converl the low-voltuge de output from the solar arrays to a (usually) higher voltage ac waveform. This operation cun be performed by the flywhecl unit with the use of a dc drive motor and a permanen magnes alternator. Also. it is usually necessiry to provide a good impedance match between the PV array and the load in order to maximize the electric poser exiracted frow the array. This function, commonly referred to as maximum power tracking. tun a'so be provided by the flywhet. Figure 6 shows the systen block diagram comparison of a battery system and inverter. a consentional fyuhecel with de inpul and output followed hy a de-to-ise inverter, and a combined fyubel sorage and pouer conditoning ssskem. The sinplicity of the last block diagram retlects the real cost sivmes nossible with this implenentation. These simplifections hinge on the use of an efficient. Jow-drag motor-gentralor and low-drag high-speed bearings, such as magnetic bearings.

\section{Sỵven 6 incept}

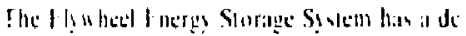

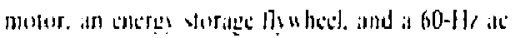

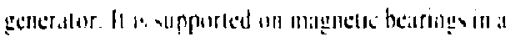
vacuum houstilg. which would do double dute in

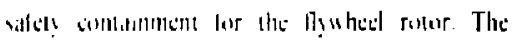

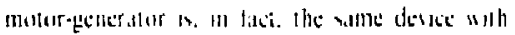

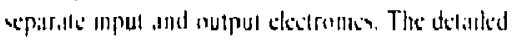

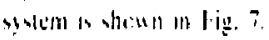

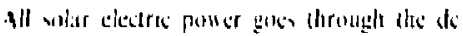

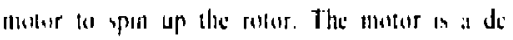

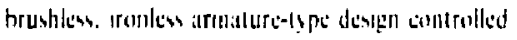

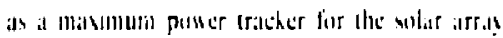

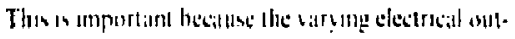

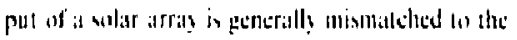

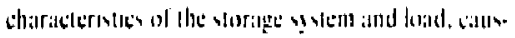

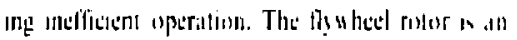

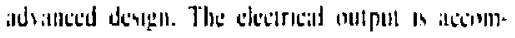

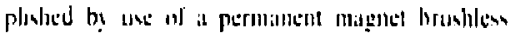

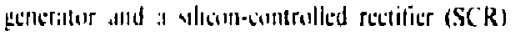

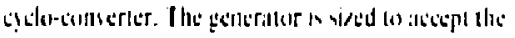

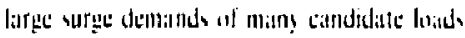

The tollter rolaling unil is supported onl a de

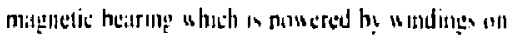

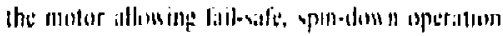

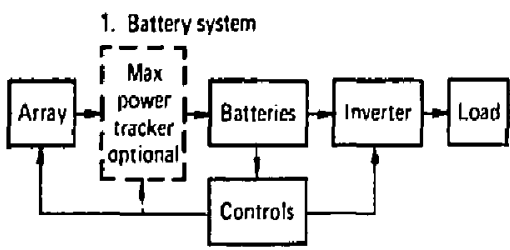

2. Flywheel storage plus inverter

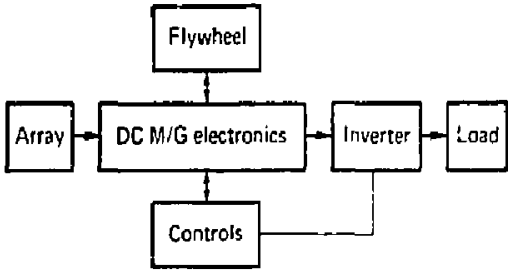

3. Flywheel storage and conditioning

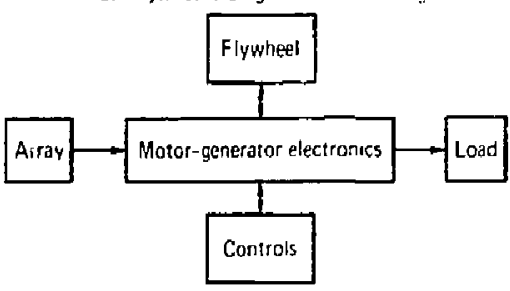

FIC, 6. Solar PV' șstem comparison.

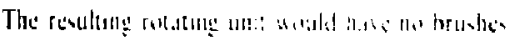

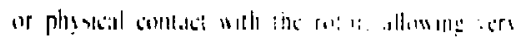
dong life:

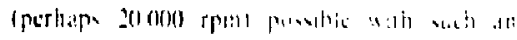

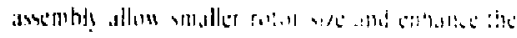

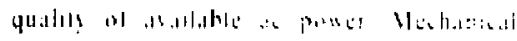

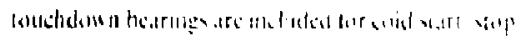

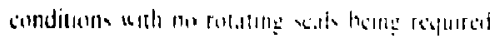

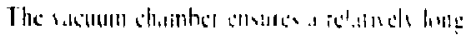

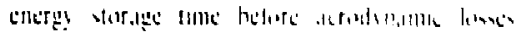

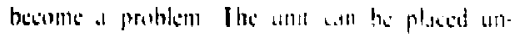

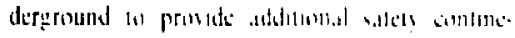

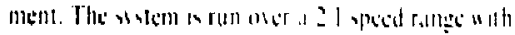

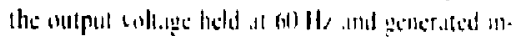

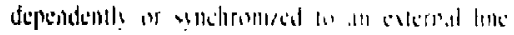

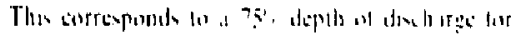

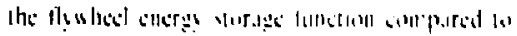

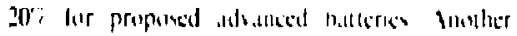

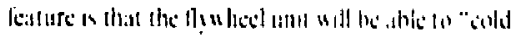

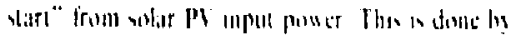

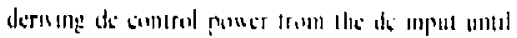

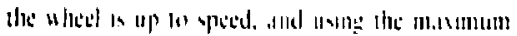




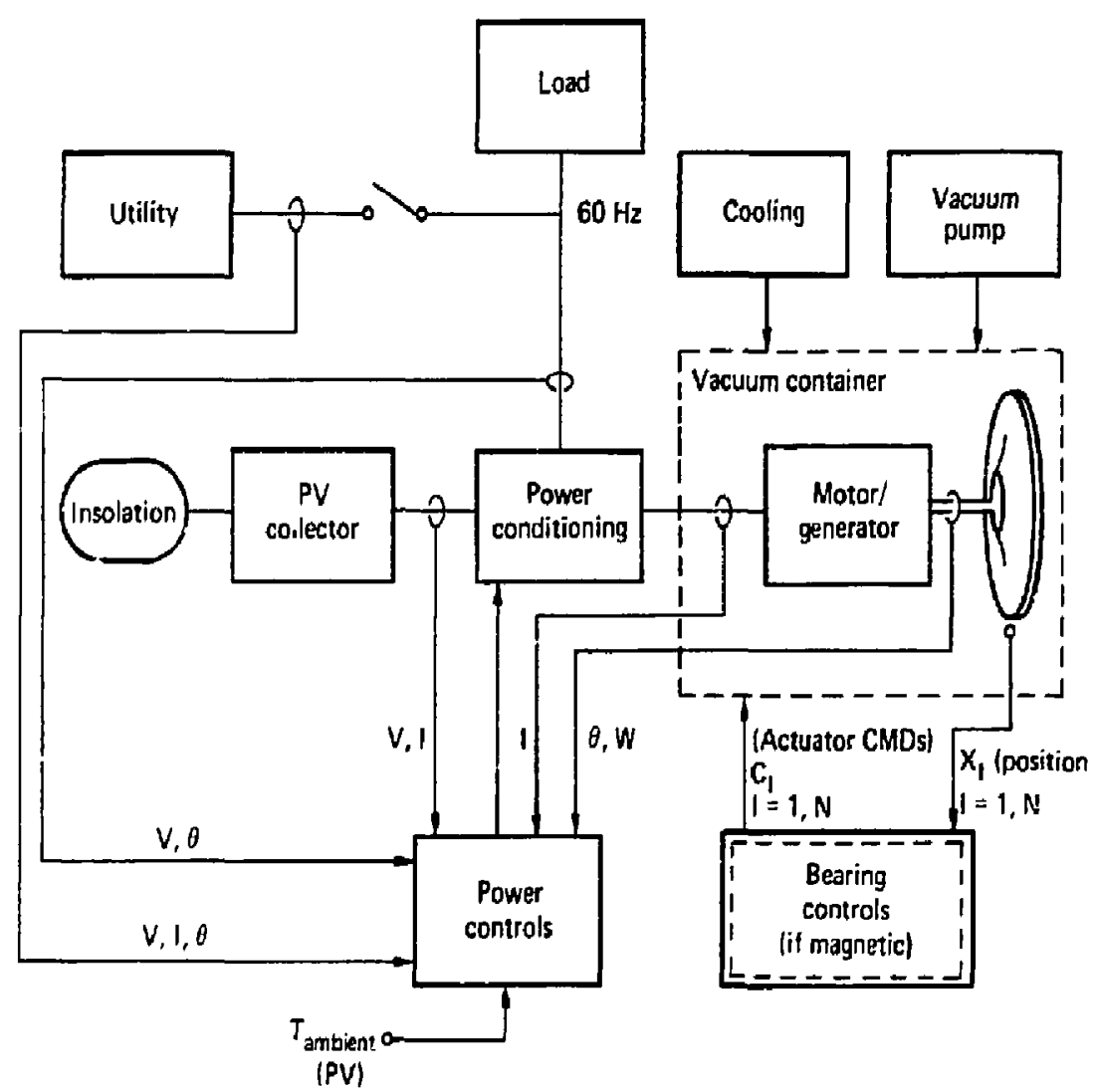

FIG. T. Detnited FESS representation.

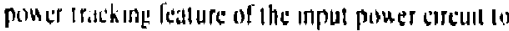
as oud pulling the inpul voltage doun too lou

The lermunis of the motor-gentratur serte als it syniming juncion for moloring and gentratigg currents, hoth hepl synchronous hy the sectronics. This illows arhierary combinations of chargeng and dischargeng pous levels within the design range of the unil.

An alloathe practual applitatuon for this devict is to utilise it with a PV-pousod singlefimils reside net onerating III èther a stind-illone mode or coupled to a utillig. Wilh ulility pouct drus n only during aff-peak hours ind only when the energy restre in the fis wheel is low. It cin be scilled up to liager siges assiocialtud sill mulaple

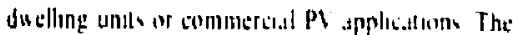

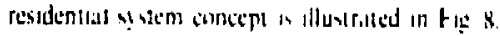

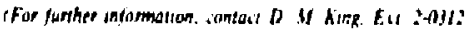

\section{Concentratos Optical Geometry \\ Diagnostics of Large Installed Arrays Lsing a Distant Observer}

A simple method for determining the geometrical atcuraç of parabolic trough modules in large. inslalled arrays is described. It is based on the principle that a distant obserter, when lowking 


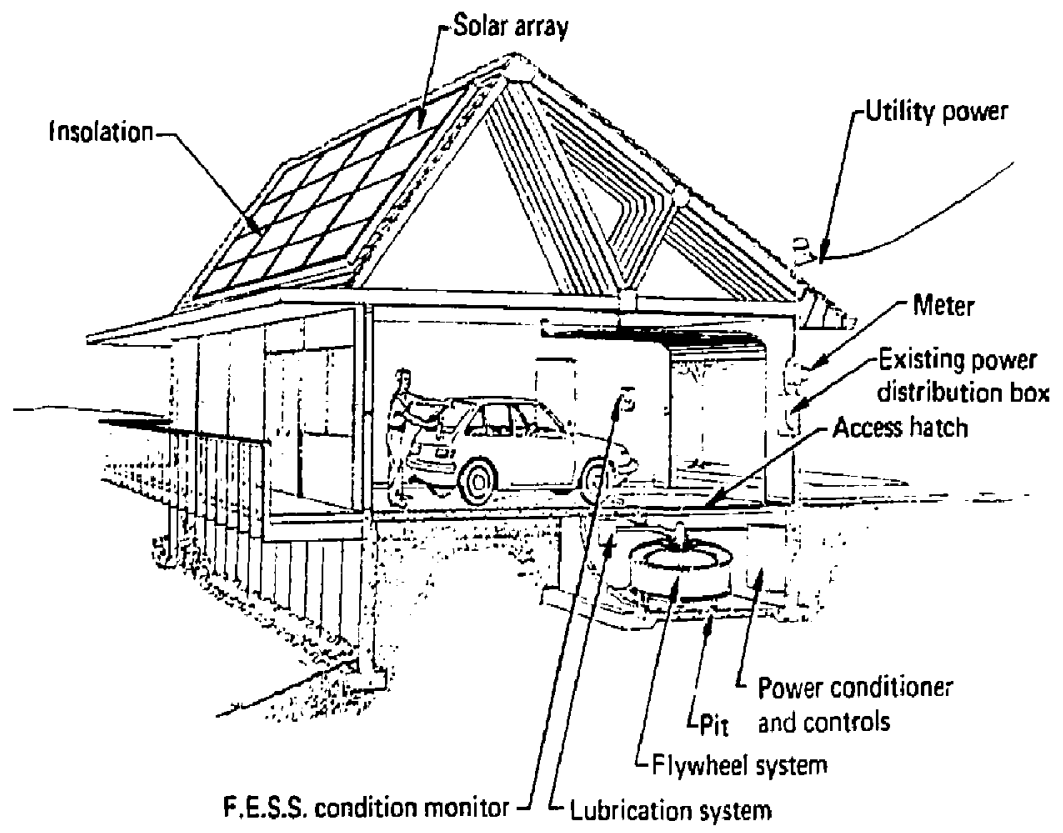

FIG.8. Residential nỵhheel energy storage sł̧stem.

into the aperture of a concentrator will sto an enlarged image of the recelver pipe reflected an the misror. The posisıon and size of the anage depends on the distanet and angular position of the observer relative to the collector and can wasily be predicted for ideal collector geomelfy. The differtnets hotween these medictions and what is acruall ohsefved can be wed to identify and quantify specilic geometrical crrors, including receiver pipe misplactment and mirror slope errors.

As the purabotic trough is rotated from trachIng to stumed position, a series of ohiservations art recorded by a 35-mm motion picture simera from a fixed position at least 10 fobal lengths atuay. The distance from observer to collector is measured 4 ith a precision hand-held ranging device. Man! modules can be tesied from a single lacution since displacement along the collec: Jf $\mathbf{a x}$ is is unimportant. The observer mily need to be clevated 10 ste snodules in the second and subsecyutent rowsis. $A$ now: pole, rooflop, or ather exjsting structure mas ho used as otherver locitions, but a hoist an seaffild may be necessiry.
Meitsurememe as miale in the lathoratsers with

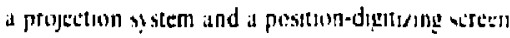
wh etectronic sylus. The data are reductd and ploted by the tomputer. Altern.t1sely. a kew precise plot sould be made by hand irom a fis punts.) Bs comparsion wath plore for sollecture wh

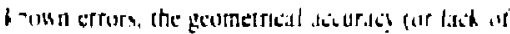
It) can he determaned and specilis errom adenutied and guantified

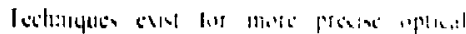

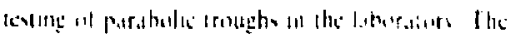

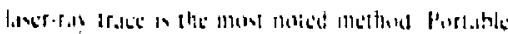

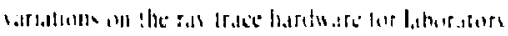

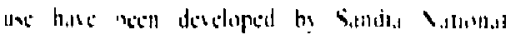

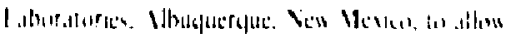

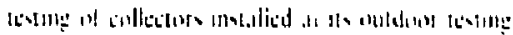

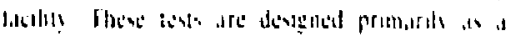

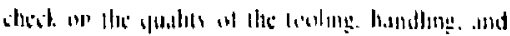

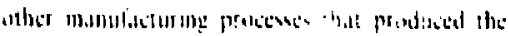

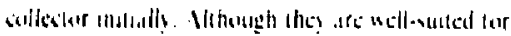

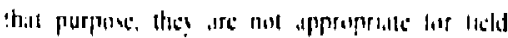

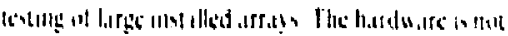

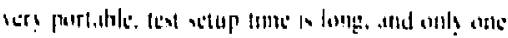


module can be ttsted for cach setup, implying consid:rable system downtime to test the whole array. Finally. the laser-ray trace method tests only the mirror shape; no indication is given of the positioning of the receives pjpe relative to the mirror.

An allernalive method involves repeated thermal performunce measurements at various off. optimum tracking ungles. This method is con. sidered less appropriatc for ficld testing of installed collectors because it requires too much system dountime and system modifications, and it is too indirect to differentiate between specific geometrical etrors.

Ouners and operitors of large arrays of concentraling collectors may wish to check out or tureup their sistems periodically. They may nol cure to tike the manufacturer's word that the collector geomeley is right. Installers may wish additional shecks on their alignment procedures. In any of these tusses, thity neted a test that gives accurate dagnontic information with minimum silt modifications. minimunt system downtime, and sile dedicated hardsare. We beliete the pholographic distunes obsicrser method to be the that for these an-site lesting purponsts.

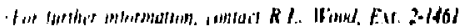

\section{Composite-Laminate Rotor Development}

The LLN1. hus betn intolved since 1978 in the derclopment of fiber-composite Flywheels. Specifically, the ohjectives of the LLNL effort ise to devetup the technology for high-energy-density. fiber-composite flywhecls based on the laminateddish cosncepl. and to demonstrate a protolype of this desizen for a prattical fly whes application.

During 1980, four lipered-thickness, laminated disk My whents ntro manufactured: two of Celion6000 praphits/epoxy and wo of \$-2 glass/epoxy conipowstes. They sere 24-in. o.d.. 1-in. thick (nominatl) at the centtr. with a taper anproximating the "Studols" uniform stress contour.

Three flat disk flywhecels were also produced. One wils 5 -2 glass/cpoxy. 15-in. o.d. by 0.42-in. thick. A steond was alsu S-2 glass/epoxy, I 1-in. o.d. b) 0.8-in. thick. The third was Celion 6000 graphitc/cpoxy, 12-in, o.d. by 1,0-in, thick.

Aluminum hubs for these wheels were bonded to the disks at L.LNL using a urethane slustomer honding process developed at LLNL.
Figures 9, 10, and II show the taperedthickness graphile/epoxy. S-2 glass/epoxy, and the constant thickness S.2 glass/epoxy disks, Jespectively.

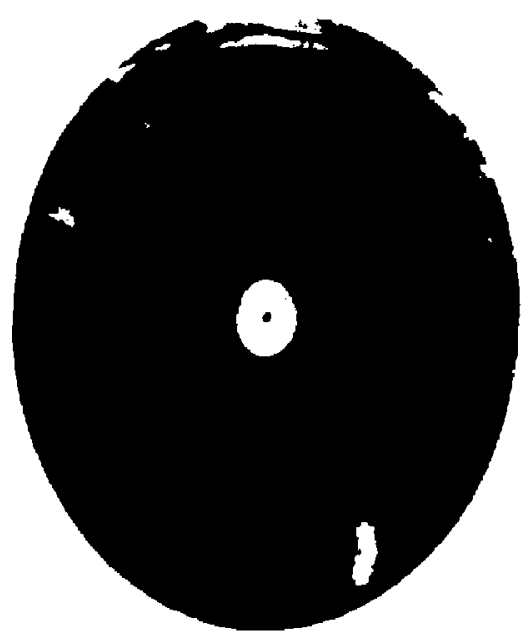

FIC. 9. Thpat thickess grephite/cpaxy disk.

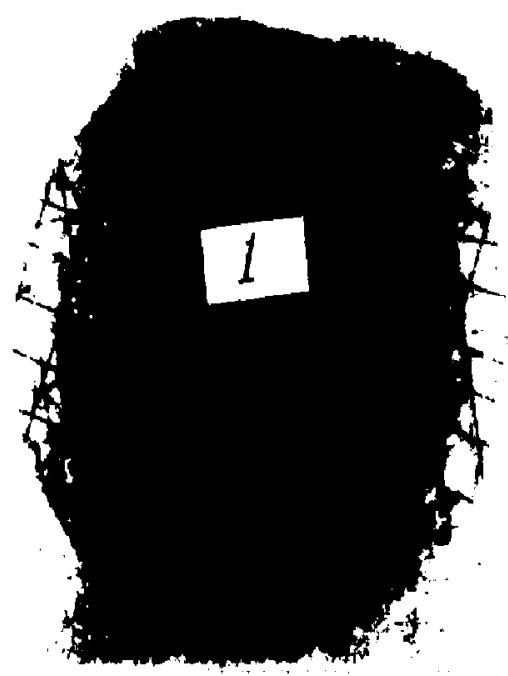

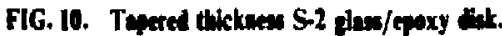




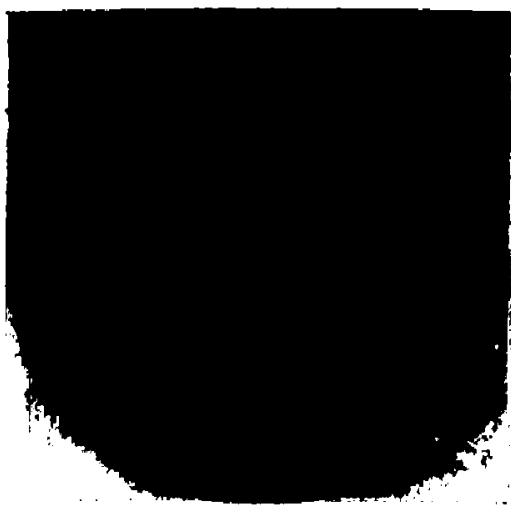

FIG. 11. Constant thickeew S-2 glaw/epoxy dut.

Four of these seven Dywhecls tave been spintested, One of the graphice/cpoxy tiupered disks wass tested at the Oalk Ridge Flywhecl Evaluation Laboratory. The other graphite/cpoxy tapered disk. one $5-2$ glass/epoxy lapered disk, and the 15-in. o.d. 5.2 glass/epoxy flat disk were tested at the Applied Physiss Laboratory, Johns Hopkins Universily.

The two graphit:/epoxy tapered flywheds Failed al an energ! dinsity or about $25 \mathrm{~W} \cdot \mathrm{h} / \mathrm{lb}$. For

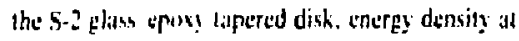
burst was $13 \mathrm{~W} / \mathrm{h} / \mathrm{h}$, fallure occurred by delamination betwen livetis along the tapered con(w)

It appears that lailue of the tupered disk M! whet is probibl! precipitited by interlaminalr shear stresss resulting From the conturing of the laminite. These strestes oceur when the baminate is subject to moplane tensile siress. (These stresses art absent for the flat disk. exeept at the edges.)

On the other hand. the fiat S-2 glass/epoxy flywhecl failed at $30.5 \mathrm{~W} \cdot \mathrm{h} / \mathrm{l}$, notubly higher than the $20 \mathrm{~W} \cdot \mathrm{l} / \mathrm{/b}$ anticipated. This represents the highest energy density oblained for a laminated disk design. Although the nyn'eel disintegroted al failure, the failure mude was benign. There viere some fibers in the debris that were 12 in. in lenglh (Fig. 12). It was nated that the hub still had approsintalely two layers of S.2 glass bonded to the clasiomer. The number one containment ring (oul of four sings) was appasen1ly unscralched, hut there was evidenie that it had rotated several revolutions utter fiilure of the Nywheel.
It is hypothesized that laminated disks will tesist higher biaxial stresses tiant uniaxial stresses. Since the material samples weie tested uniaxially, these values were used for predicting the performance of the flat disk S-2glass/epoxy flywheel. The spin-test performance of the flat disk flywheel appears to bear out the biaxjal strengthening effect.

The hub-to-wheel elastomeric altachment performed successfully in all tests thus far.

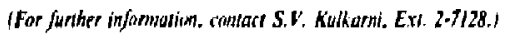

\section{Study Conducted to Determine Fens"bility of a Toroidal Traction-Drive System}

Mechanical energy storage technology (MEST) is applicable to a variely of vehicles in the transportation sector. It has the potential for contributing towurds significunt energy consers:ation by (1) reusing energy normally expended in braking. and (2) by optimizing the prime mover energy rates for more efficient operation. Reenily. flywheel energy storage technology has heen used by the University of Wisconsin and the Marshall Oil Company. They demonsirited that be incorporation fla whed units with conventicrial, heal entins puncered setricts.

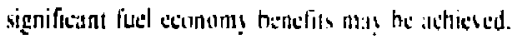
Ilowewer. for the heal engine My whect (HI: FW) system to be successful. an effickent. conninususty variahle triltsmionion (CVT) untem must he descloped.

The objectine af this yod! was lo menestgate different CVT-bomponent yitem and the associatid transmission comportents nectonsiry 10 assemble a CVT ywem cupahle if mectung the specifications detcrmsned necewars for obtaining signifuant futt coonomy. It considers aff-conter. toroidal, traclion drites. Preliminary desgng layouts of various stitems sere analy sed usine compuler simulation; a detailed analysis for each CVT destgen wass perforned by Tratelun Propulston Incorporatted (TPI). including efficiencs cotumates, 6untale stresists. life prediction. and film lemperatures.

The toroidal-type drive unit has been designed and built by TPI for incorporation into a number of different applications. It has proven to be of sound design, quiet. capable of withstinding high speeds and sho:k loading, efficient, and relatively sosy to 


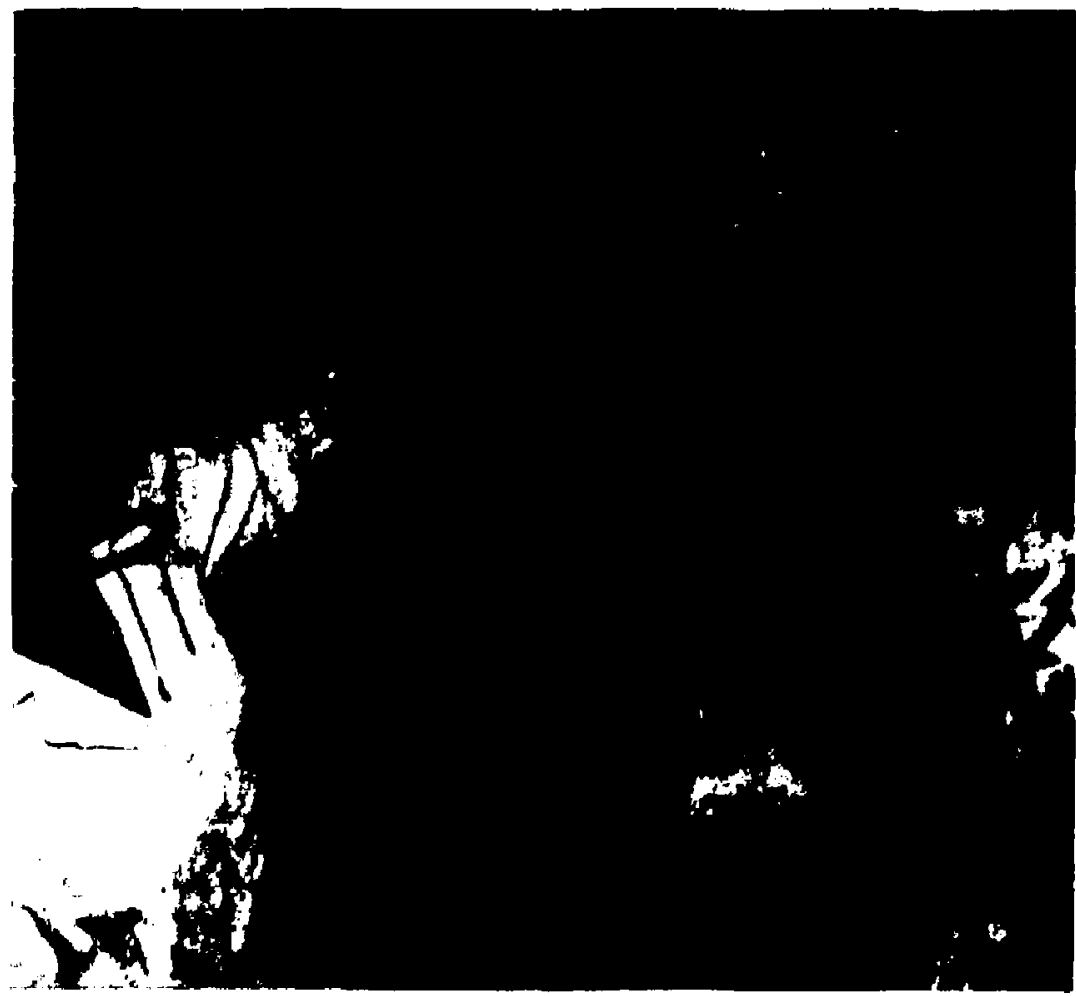

FIG. 12. Test debits of 1.LNI, S-2 glass/epoxy fat disk.

manufacture. Lubrication within the tedction-drive design is elfected by a low pressure pump (20 psi. $2 \mathrm{gpm}$ ). Monsanto traction flutid, Sanlotrac 40. wils be used for all internsl lubrication An oil-10-wates heat exchanger will be used to cool the oil. The exchanger will not only transfes heat to the engine cooling water, but it will also transler heat to the aransmission oil during cold startup.

Control of the toroidall Iruction-drite unit will be accomplished hy hydraulic meenls, $A$ mediumpressure ( 200 psi), low-flow punsp will be tmoployed. The transmission design requires no nuort than $0.25 \mathrm{gpm}$ of control oil. All ratio controls will be uutomatic in response to signals from the accelerator pedal and from ratio-sensing tritnsducers.

Four $\mathrm{CVT}^{\mathrm{T}}$ systems were considered initiall! feasible for this applicalion:

- Continuously variable drive (CVD) with a powershift.
- TuoCVDs in strits.

- Regenerative CVD.

- Multinoded CVD.

Eusth of the four configurations for the drive line system provides a workable alternative for use in the heat engine/flyuhecl-drive vehicle. The relative acceplabilit? of the systems is largely a funclise of operating efficiency and acceptance of the şween performanset by vehicle operators.

Fixed-ratio, truction-drive speed reducers are included in each system to reduce the flywheel speeds to a level within the operating limits of the hest engine. For the dual-CVD system, a reduction ratio of about 3.75 to 1 is required. as the flywhecl CVT will further reduce the speed as necessary. The other three systems require a ratio of 6 to 1 . depending on the amount of additional reduction supplied in the power train. For high speed nywheels, a lixed-ratio speed reducer and clutch 
should be placed between the flywheel and its CVT. The efficiency of the speed reducer, operated at full load and speed, is between 96 and $98 \%$. Half of the losses are speed-dependent. The rest of the losses are torque-dependent; the efficiencies, which are calculated at the rated speed and half power, snow twice the percentage loss as those calculated at full load.

The ratio range availahle from the CVT affects both the operating efficiency and the overall system performance. A highly tfficitent, hut nurrow-ratioed CVT misy show a lower system efficieney than a less efficient CVT wilh a wider pange. This is due to the opuratting charatleristics of an inlernal combustion eragine and the amount of elutch slip netestary to accelerate the vehicle up to a speed which cun synthronies with the fly hetel input. For this season al wider ratio range than the 12101 is retomnended.

The multimoded CVD (Fig. 13) appears to be the best choice for the HE/FW vehicle. It has a wide fatio range $(60 \mathrm{to})$ ) with the best efficiencies of the systems studied.

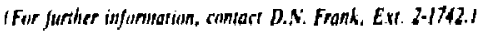

\section{Ultrasonic Inspection of the MFTF Magnet Cover Welds}

The first magnet pair for the Mirror Fusion Test Facility (MFTF) has been fabricated (see Fig. 14). The cover for the superconducting

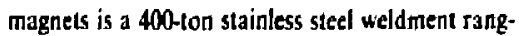
ing in thickness from $76 \mathrm{~mm}$ (3 in.) to $127 \mathrm{~mm}$ $(5$ in.) Early calculations of maximum stress and strength of the material at liquid helium temperature indicated that the "worst case" critical naw sizes would be on the order of $4.8 \mathrm{~mm}$ (3/16 in.).

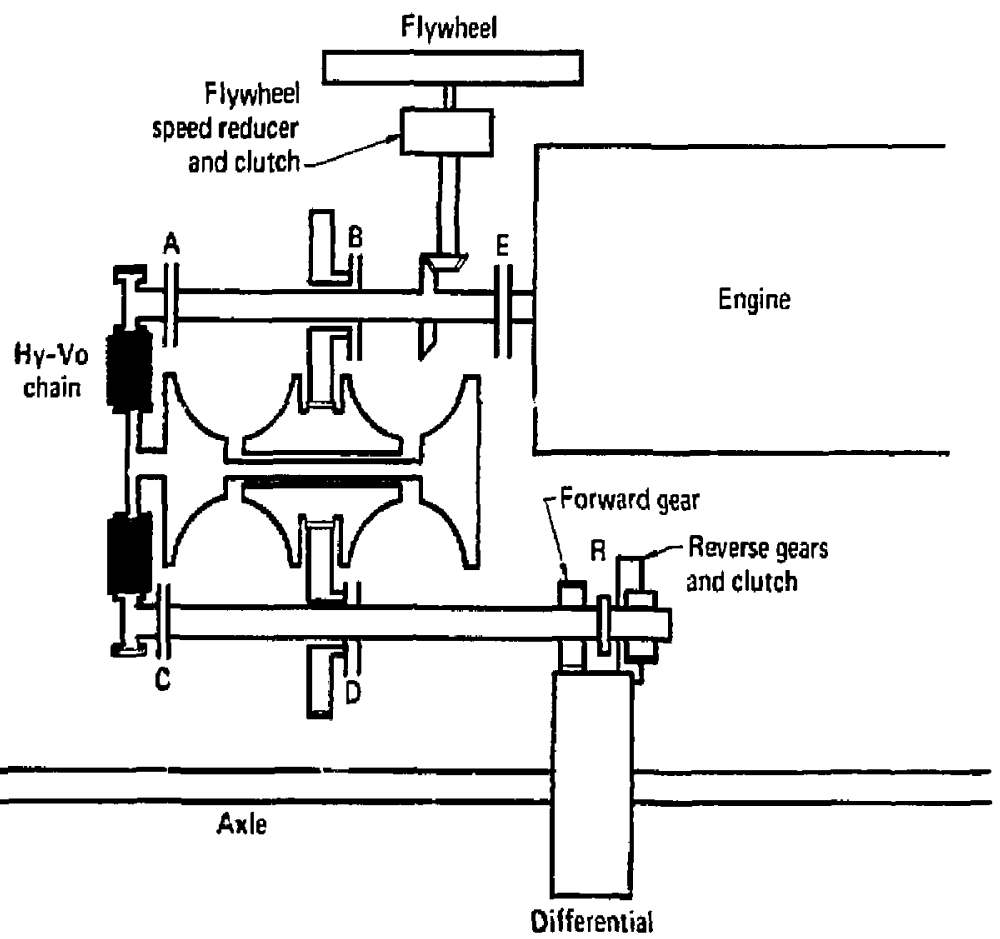

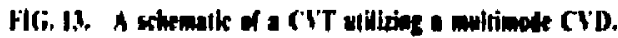




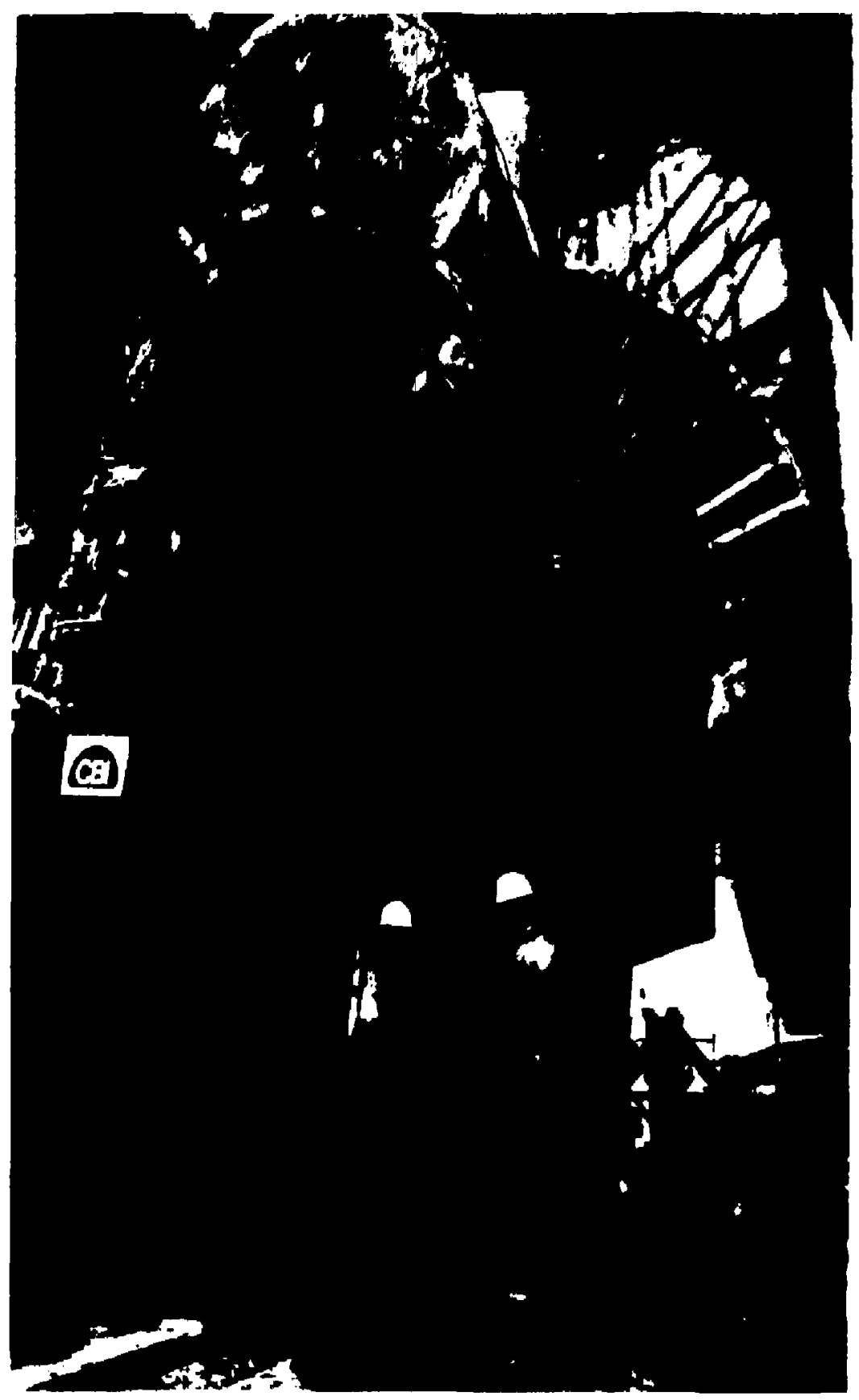

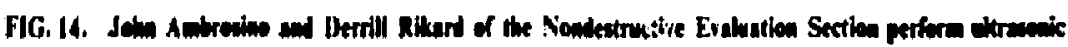
erductiou of the MFTF Yiw.Ying anget cte. 
The inspection technique best suited for this weldment was ultrusonics. However, ultrassonic inspection of stainless slecl welds hus always been difficult duc to the variability introduced by grain size and orientution in the weld material. $A$ dialtransduser lechnique sugessied and purfected by a transducer manufacturing firm. KB-Atrolech, was used. The inspection involved hand scenring by technicians Derrill Rikard and John Ambrosino of the Nondestruclive Evaluation Section, Ken Sumikawa of the Engineering Meusurement Section and Glen Nypisk of the Materials Test and Evaluiltion Section, on moic than $600 \mathrm{~m}$ of weld over id period of a yeat. The inspection was accomplished under extremely adverse conditions involving the weather. noise, scheduling to uroid working under welders, climbing around on scalfolding, and interpreting quite complex results.

Figure 15 shows the transducers coupled to a reference block and the ultrasonic data display instrument. The instrument performs three functions:

- It supplies the driving tenergy in short. duration pulses to the transmitting transducer to produce the witrasonic waves.
- It amplifies the electrical signal produceo by: the receiving transducer.

- And it displays the electrical signals that are wideband pulses of approximately $2 \mu \mathrm{s}$, with a center frequency of $1.5 \mathrm{MHz}$.

The operator observes the location of the reflected pulses in time to interpret the depth of the flow indication and the amplitude to determine its approximate size. Calibration refetence blocks were made to determine the sensitivity and variability of the iransducer response at sarious depths for buth double-sided V-groove welds and one-sided $V$-groove closure welds. The slosure welds wete made over a backup bar. Variations in the fit produced a variety of reflections that inteifered with the interpretalion of data in those regions. The intterpretition required a thorough knowledge of the range of fit that might exist and a visualization of what the results indicated in order to make a racher subjeclive evaluation of the data.

Uilrasonic reflections thal there delermined to he flaws and were greater in amplitude than that rectived from the end of al 4.8-mor-dian) (3/16-in.) flat-hollom inole were secorded. Flan indicalions.

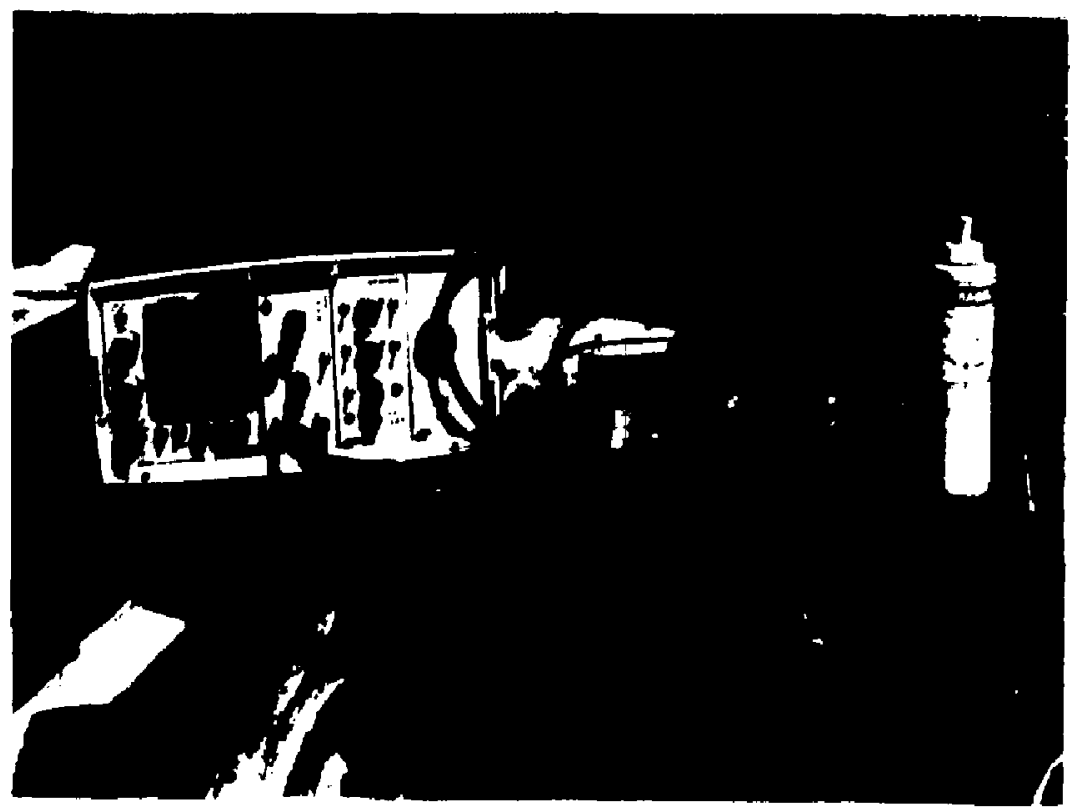

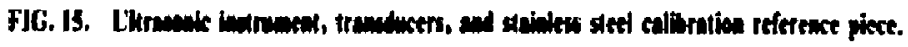


that appeared to be greater than $6 \mathrm{~mm}(1 / 4 \mathrm{in.})$ were repaired.

The repairs uere made by arc-air-gouging the weld ntaterial out and reuslding, Many of the flaws were found during the gauging process. They could be seen in the cooling metal just hehind the are. Slat inclusions were tasily sech, but lask of fusion was more difficull. Sonce lack of fusion or tracklike indications were found by usillg dyc penetfants afiter each pass of the art-aireguging.

As mentioned, the major difficulty was interpretation of results in the root of the closure sotd where tackun bars were required. Further dewiop. ment to decrease the ultrasonic beam size could improve the lateral resolution by a factor of 4.

The rcsults of the ultrasonit inspection of the MitTF magnel tast ueld were encouraging. Fusther develupment is planned that will conssderably improve the interpretation of dati. Improvements in the inspection time required are imperative since the ne'st phasc. the MFTF-8, includes another mirror magnen pair like that just completed. plus 14 solenoid coiks and 4 C-shaped shaping coils.

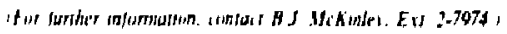




\section{MAGNETIC FUSION ENGINEERING DIVISION}

The Magnelic Fusion Engineering Division (MFED) supports LLNL's physics programs in three principal areas:

- Magnetic fusion encrgy (MFE) confinement experiments.

- MFE development and technology.

- Particle beam development.

Although the gouls differ tereally, the theec areals shate a common lechnology hasce. Supporl is needed from sirtually all mechanicul tongineering disciplines, is $n$ ell as from engineters specializing in normal and superconducting magnetics, eryogenic untems, vicuum susterns, high-sollage components. and nucleonics

Our role in MFt confintment experintents is 10 provide the s!stem, entginecring. design. ind fahrication of nechinnieal hardwale. This restisch III the manetic confinement of nuckar fuvion reattoms is axpected to lead to tapping deuterium. all

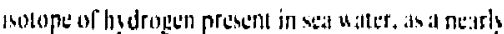
methausible energy soure. The major confinemenl experimentits are the Tandem Mirror Eaperi-

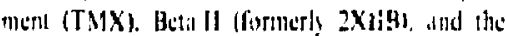
Mirrer Fuston Test Fatily (MFTH)

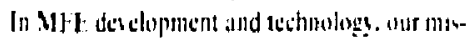

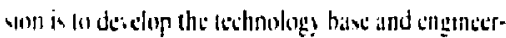
ing whills netersilrs to metel the future needs of

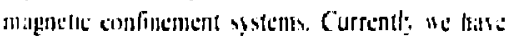

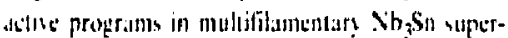

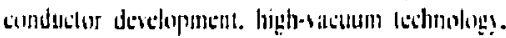

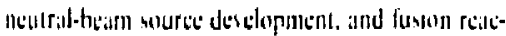

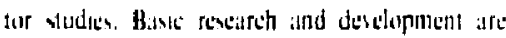

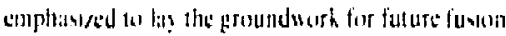
coperimemes.

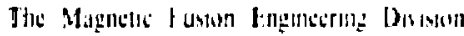

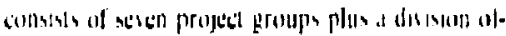

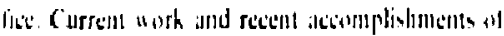

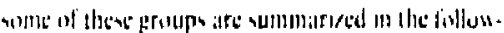
int pugen.

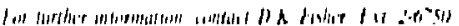

\section{Dexelopment of High-Field}

Supereconducting Magnels for the Next Generation of Mtirror Fusion

\section{Rewwen liacilition}

Onte of the major tasks ander wats in the

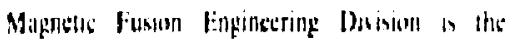

development of multiflamentary $\mathrm{Nb}_{3} \mathrm{Sn}$ high-field conductors. A significant part of this program is the building of a large magnet incorporating the newly developed conductor to generate a field of approximutely $12 \mathrm{~T}$. This magne! and its assesiated equipment have become known as the LLNL High Field Test Facility. since it will be used to demonstrate not only the high-field conductor developed for the mirror program, but also to test conductors developed for possible use in Tokamak toroidal field coil applications.

The magnet windings consist of four outer mobium-titanium sections. which provide a hackground lield of $8 \mathrm{~T}$ in a $\mathrm{I}-\mathrm{m}$ bore, and two inner wetions. woind with the nes $\mathrm{Nb}_{3} \mathrm{Sn}$ conductor to increast the lield to $12 \mathrm{~T}$ in the $10 \mathrm{~cm}$ bore.

Thic four outer coils, weighing a total of just wer 20 conts, have now been fabricaled and tested to liull field and current when the tolal stored magnetic cnergy is $40 \mathrm{VJJ}$. Figure 1 shows this coil assembly about to be lewered into the 3-m-diam cryostat for tentring.

The particle beam development program. lunded by the Defense Advanced Research Projects Agency (DARPA), involves building high-current, hith-tolsuge, electron accelerators. Such accelerators are of interest in basic physics research and the weapons community. The present program culls for development of twa accelerators. the Experimental Test Acceierator (ETA) and the Advanced Tesl Aecelerator (ATA). The ETA program is the predecessor to ATA, and will generate the Itchnology data base to build the 10-kA, 50-19eV ATA mathint.

The deselopment program for the No Sn conductor wis described in the previuus Mechanical Ingentering Departmant Technical Review? producturn lengths of this conductor ate nou being fabrisated and winding of these two coils is ahous to cornenerict.

After winditug, the $\mathrm{Nb}_{3} \mathrm{Sn}$ colls will be assemhlod ilside the niobium-titanium stack and the st thole will be tested as a unit. with its asis vertical in the cvistine ?-nj-diam cryostat. When the facility is ustd fur itsting Tokamik development conductors, the ino $\mathrm{Nb}_{3}$ Sn coils will be parted in the center and the sinducturs to be tested will be inserted between them, thes using the facility to provide a baskigreund field of approximatel! $12 \mathrm{~T}$. Since the 


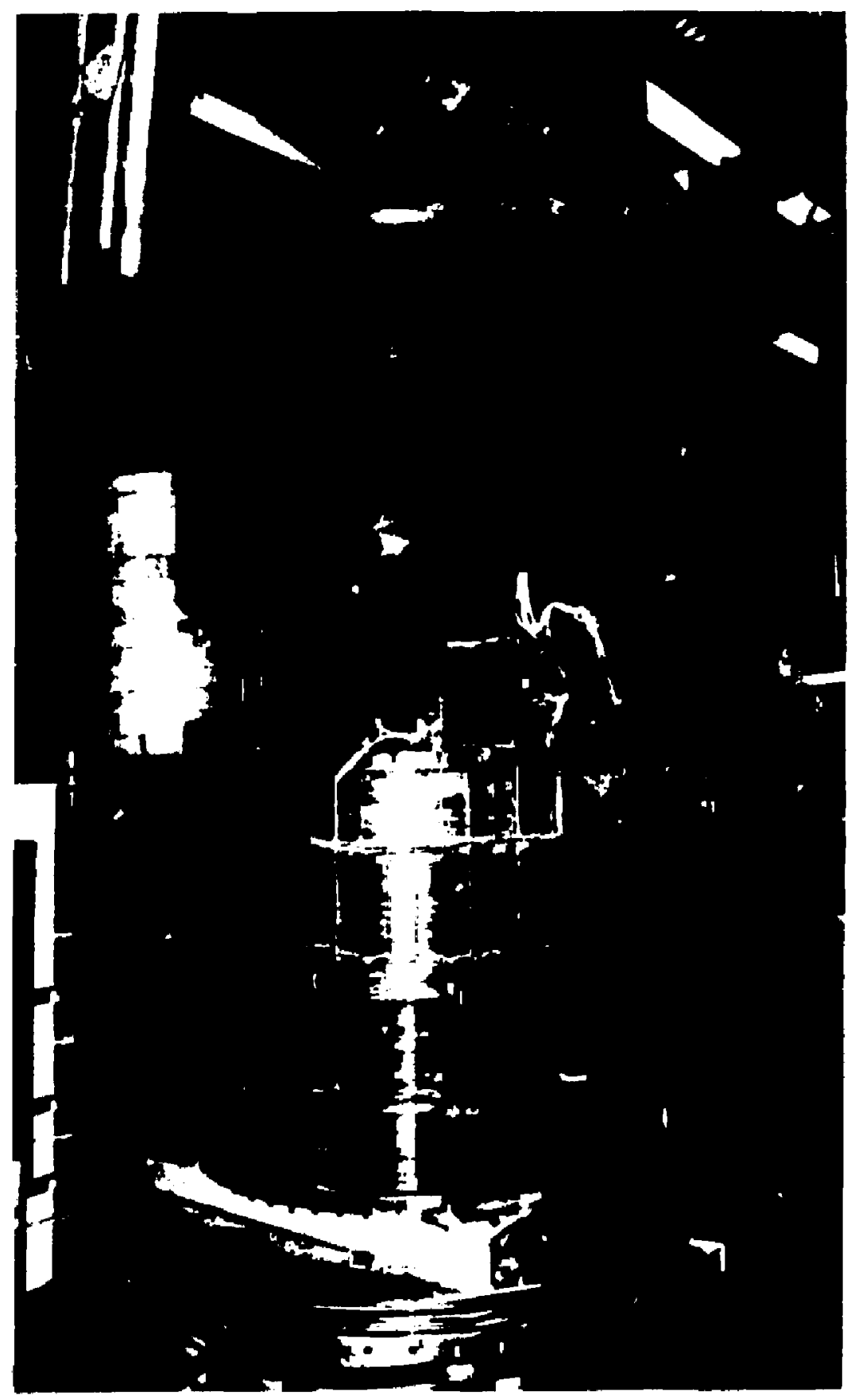

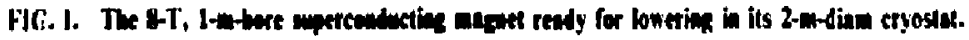


stability performance of a pool-boiling conductor is orientation-dependent and since Tokamak toroidal field coils have their axes in the horizontal plane, it will be necessary to use the facility for testing these conductors also with their axes horizontal. This requires a larger cryostat: a $4 \mathrm{~m}$ unit has bee designed for this purpose and is now out for bid.

The larger miggnels and high lields now buing buill in this development program sunnol be alcommodated in the cristing eryogenic laboratory. $A$ news separate laboratory is, therefore, heing huilt for tite sole purpose of deteloping superconductors and superconducting masnets for the Mirror fusion Program.

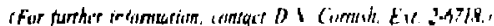

\section{First Pair of MFTF Magnet Coils Nearing Completion}

The mission of the Magne Systems group for the Mirrer Fusion Test Facility (MFTF) is 10 design. labritalte. and test 22 large superconductinge

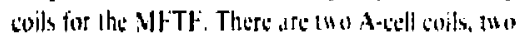
Yin-Yang coil pairs two transition coils, allod it sulenoid coiks. When completed, thẹ will constitute the world"s largest supersond usting coils.

The group's latest work hus included completing the winding and inspection of the first pair of Yin-Yang coils and turning them over to a contractor. Chicago Bridge \& Iron Company for final welding of the coil cast. This work is now nearing completion. The Magnetic Fusion Enginecring Division also awarded the largest contract erer let by the Laboratory-\$31 million-10 General Dypamies/Convarr Division for design und fabrication of the A-tetl. transition, and solenoid cuils.

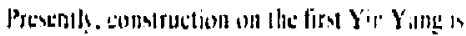

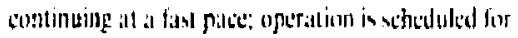

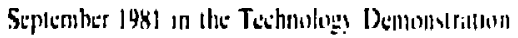

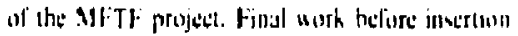

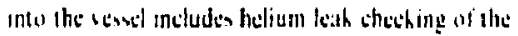

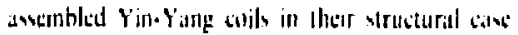

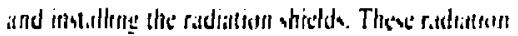

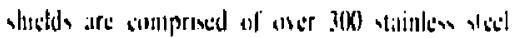

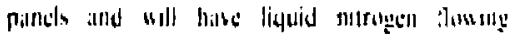

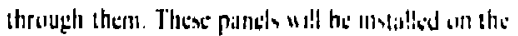

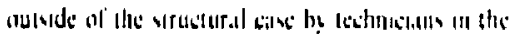

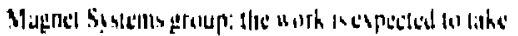
werral minths.

\section{Instrumentation Requirements in Planning Stage for the Magnetic Fusion Test Facility}

The mission $\mathrm{c}^{\mathrm{r}}$ the Magnetic Fusion Test Fucility"s (MFTF) Diugnostics Group is to plinn, design, and fabritith the plesma diagnostits for the MFTF. The Duegnostics Gooup is curently supporting the physicists in developing the requirtments for the diagnosties instrumentation.

Designing and fabricating the required instrumentation will be carried out in two phases: (1) The "stariup set"-the instrumerts that will be needed in the lirst few montins of operation in 1984: and (2) the "basic set." which will be the additional instruments necessafy to complete ill the diagnostics measurement goals of the MFTF.

Funding of the startup sel will not begin until lute in the 1981 riscal year.

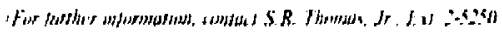

\section{Studies of Magnetic Fusion Reactors Point to Commercial-Scale Designs}

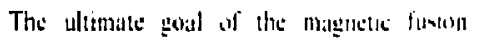
program at L.L.YL. is the dectoponent ut matenctic misror devics for the economial produstion of

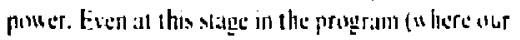

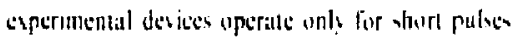
and consuine more cherge that the pronducit. "s:

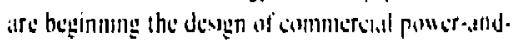

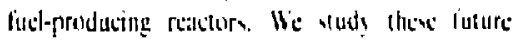

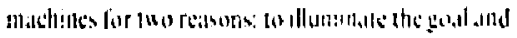
thus gitse guidance to our curremt ceperintemlat

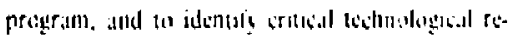

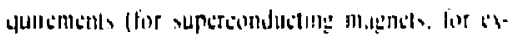
imple) which requare detelopment.

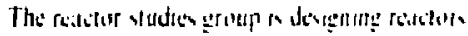

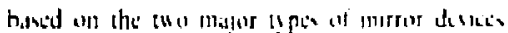

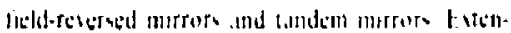

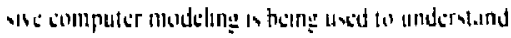

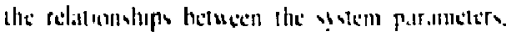

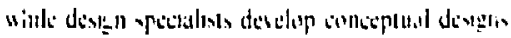

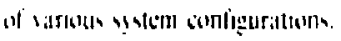

Figure 2 is a drawing of a tandem mirror tedstor designed to produce about 500 .3W of elcitrical poster. The reacling fusion plasma which products the pouter is confined to the 56-m-long conural o linder of the reator. In this crmral region. a "blankel" sursounds the rediting plasnla to absorb 


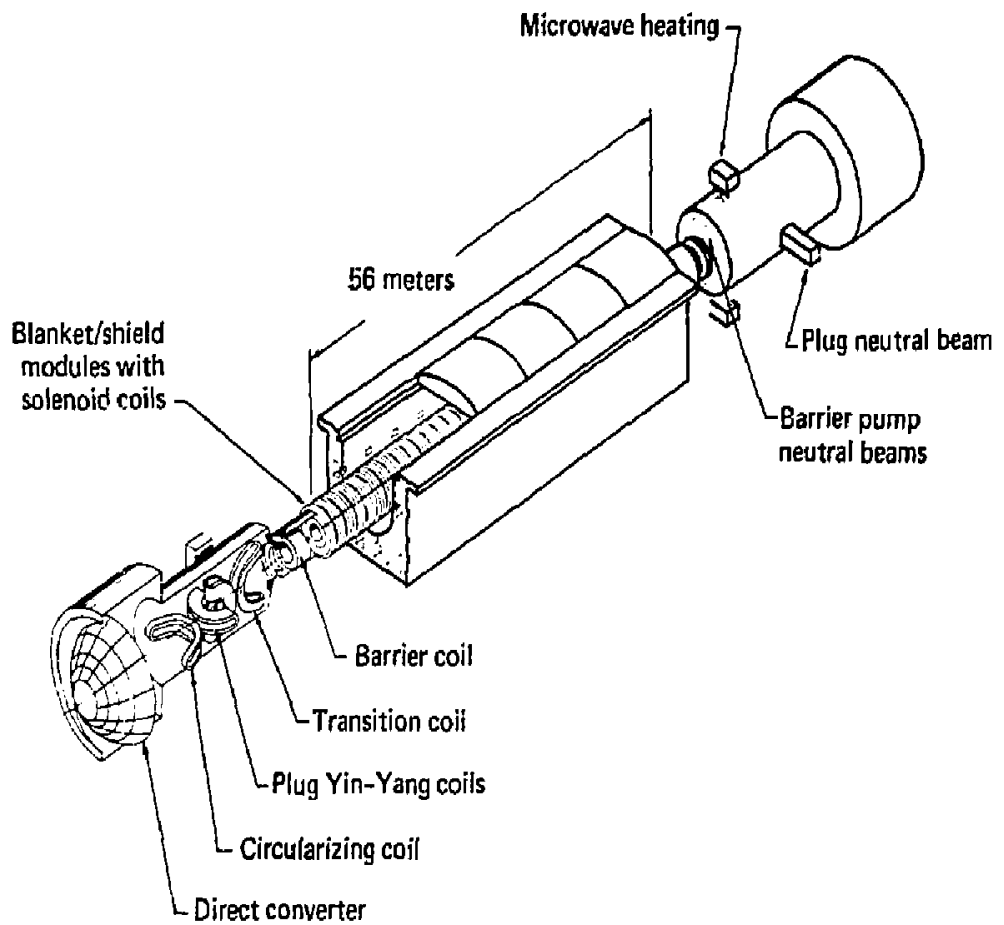

FIG. 2. Enginetring consept for the 500-MWe Tandem Mirror Reactor.

the fusion power and to transfer the heat to a turbine-generator plant. Cylindrical magnets surrounding both the plasma and blanket produce a longitudinal magnetic field which prevents the sideways loss of the plasma. The riddle two C-shaped magnets (called a Yin-Yang pair) contain a nonreacting plasma whose electrostatic potentia] reflects the reacting plasma back into the central region.

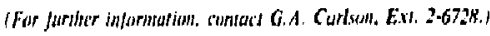

\section{Engineering and Construction of the Advanced Test Accelerator is on Schedule}

The Advalued Tesl Accelerator (ATA) group is respontible for designiı, and constructing it linear induction aceulerator with which is ank pirically sludy clectron betan pro, sation and to validate the existing theory. Critital propagation ex- periments will be conducted in various gesses and in aif to determine the range of beam piramelers leading wo stathle and controllahle selfforocusised propagalion. The atecelerator performante charasteristics sequired to conduct thesi caperiments are is follows:
- Current
$10 \mathrm{kA}$
- Entrgy
$50 \mathrm{M} \cdot \mathrm{V}$
- Pulse lengla 70 ns. FWhM (50 no Rantop)
- Repetition rate 1000 pps max for a 10-puise burst every 2 s

The acceleralor consists of a $2.5 \mathrm{Mt} \mathrm{M}$ injector and 190 alcielurutor uniss, tath of which adds 250 kuv of cnergy to the hearn. Each of these units hals its ow n pulse power system, acceleralor savity, and magnet system. Clearly, liming and contro! ate eritical issues for successiful operation.

The ATA program is a vital part of the LLNL Charged Purticle Beam Program supported by the Delense Advanced Reszarch Projects Agency through the Navil Surface Weapons Center under the U.S. Depurtment of Defense's Chair Heritage Progrum. 
The ATA program is heginning its third year and is progressing decording to the original projectivns. The main building and other consentional supporl facilities afe wetl into construction and sunce are complett. The structuril partion of the eunnel that houses the aceelerittor is complete and backfilling is in process. Stop arceas, supporl power. and fluids șstems are heing instuiled. The building 10 house the power conditioning equipment is wheduled for cumpletion in Oclober 1981.

The accelerator sontem is designed and nuss of the cumponemts are in carious phases of procurement. The Protolspe Tess Sland is still in ciptration. providing linat intormation on mitternats in the

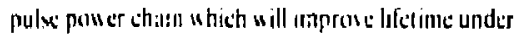
high electrest srewes. Texting has demonstrated

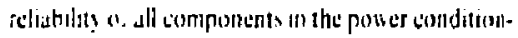
ing ihs.sin and on the atcelerater by accumulating

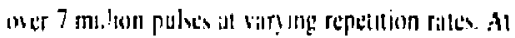
lhe poun. ATS thas sthesed the following paratileter:

- Iull wilate for cach module of $250 \mathrm{kV}$ w/th $10^{5}$ pulser it $350 \mathrm{kV}$.

- P'ulser risetime of less than 20 ms.

- Vofilige llittop of $50 \mathrm{~ms}$

- Pulse udithat FWHal ol 70 ns.

- Sparth flip pitler ol less thain I ns.

- Repectitusn rate of gerciler that $1000 \mathrm{pps}$

These duta provide high confidence thal the requisile performance charackeristics for the criticul sxperiments will be athieved with flexibility in much of the sistem for operation at higher levels.

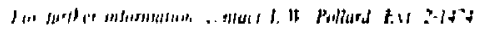

\section{Synfucls from Fusion: Producing Hydrogen with the Tandem Mirror Reactor and Thermochemical Cycles}

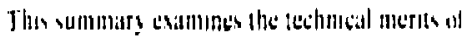

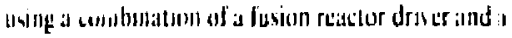

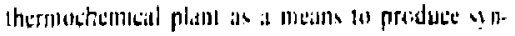

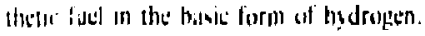

Our hidy centred three major concepts:

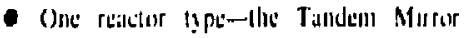

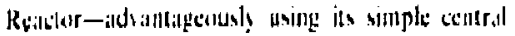

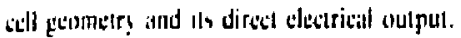

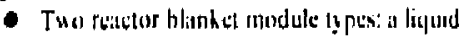
metial cualdrem design and is flowing Li, $\mathrm{i}_{2} \mathrm{O}$ woljd microsphere pellet design so is to compare the technology. the thermal-hydraulies, neutronics, and tritium conlrol in a high temperalture operating mode $(\sim 1200 \mathrm{~K})$.

- Three thermochemical cycles-processes in which water is used as a feedstock along with a high temperalure heal source to produce $\mathrm{H}_{2}$ and $\mathrm{O}_{2}$. The water-spliting process is a closed-loop sequence of chemical reactions in which the reagents are continuously recycied. The cycles are the Genteral Atomic sulfur-ivdine: the Westinghouse sulfur: and the Ispra Joint Reseatch Centre (lspra. Italy) sulfurbromine cycles. Only these three cycles, of approximately 30 studied worldwide, have been developed to laboratory model levels and produced demonstration quantities of hydrogen.

The major conclusons from our incestgations arec as bicilow.

- Nie are salssied that the preductison of hydrogen uning therminchemest aycles his : demennatralted weterintertial hase and pulential for commitrial soplor.aun.

- There irre only threc driters for the

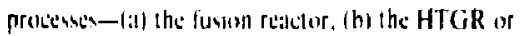
YHTR, and (c) whar

- W drisers the funon resteler and the

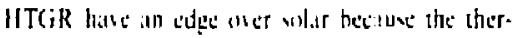

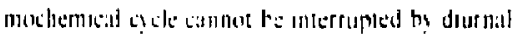
cillects.

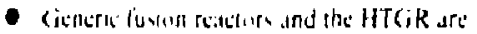
beth giend catndilition for sintuel driner.

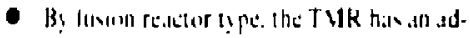

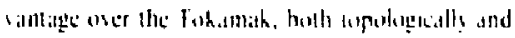

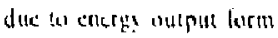

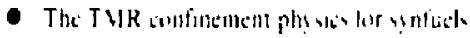

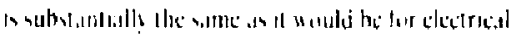
producilain

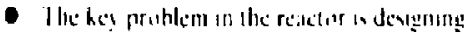

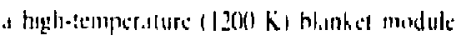

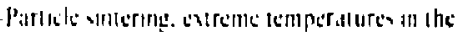

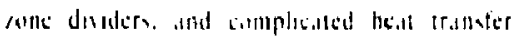

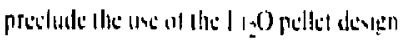

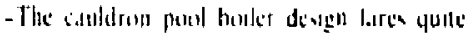

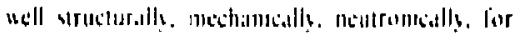

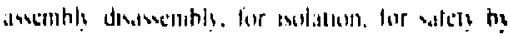

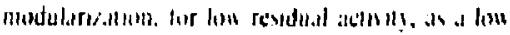

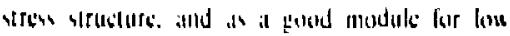

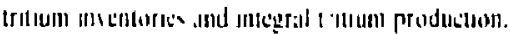

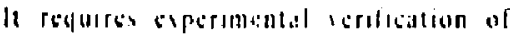

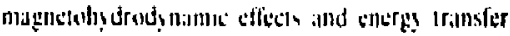
"shlhu lle poul. 
- In toller blinhite design. the quantily of process hetal delisered to the chemical plant at 1200K was accillent, apprositmatel! 90\%.

- Malcotals prohlems al 1200 $\mathrm{K}$ ind in corrowst altromplicese alre difficult. Howeret. He are colcouriged in having found a ste of conlemporary mattrials beliesed adequatc for the temper:aturc enemonment situalions.

- Nit bete ve have introduced an improved devigh lor the $\mathrm{SO}_{3}$ dectompentr-the mos difficull aliti un llet shemical plant-hy using a alloidised bed

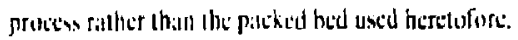

Wo tontulude that the fusion/synfuel tic is a good ont with a high es entual payoff. The problems are difficult but the study is in its infancy. Even duringe thos shart atudy periad, He have begun to resnlve sorne of the problems and sec possible solutions for others. The program Marsants support and te therefore seconmend this follow-on work:

1. I plusaltem of an illernative to the baste cisuldron hlankel moduli-the saldron wath heat pupes

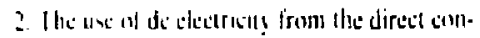

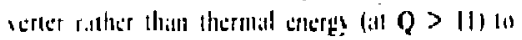

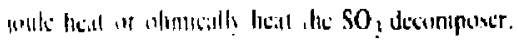

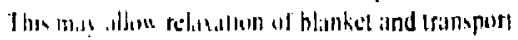

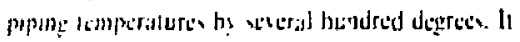

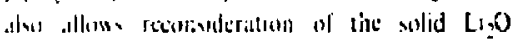
b). nnkul

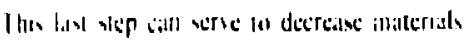

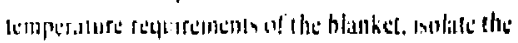
lagh icinperalures lot the SO, decomposer unit and

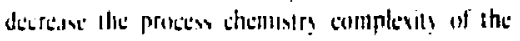
sulturis aced stitum af the process.

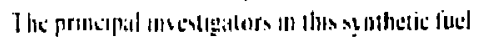
slude are R. W. Wernet af alic Magntetic liusian

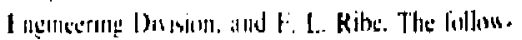
In! ure controhulors: R. Husch. B. C. Pricer.

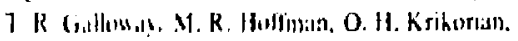
D) S. Rint. and (i. L. Windrall.

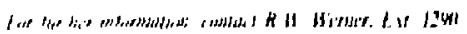

\section{The Tandem Mirror Yisu Sicp Conceptual Design}

The division hat hegun al stady lo dufine the foillure, of an enperimental mirrar lusion debicu-lias Tandem Mirtat Neat Sicp (TMNS)- bial will hridge th: gilp hetwen prestill mirror confintment experiments and a pouerproduling resctor.

The TMX-U and MFTF-B seglerence of experimens are expected in provide the plassmia phystes base Mutded for the design af as landem-mirsor fusion-power reacter. These experiments. partitularly tho MFTf-B. will aloo demonstralte ntuth

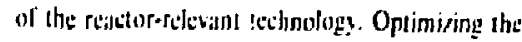
path betucen MITF-B and canslruction of a demkenstration commercial power plant of the nurfor type will require a desce la hreng the pha wo paranceters it linal skep lo the reattor regime and io itst and demonstralt: all of the lecthnolog! and

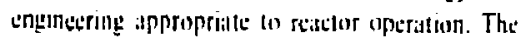
purpose al the prencm sluds is to detchen the

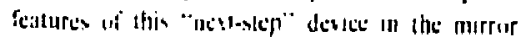

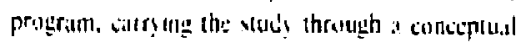
derign phast.

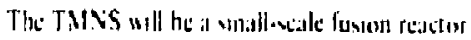

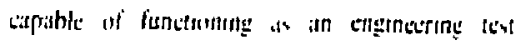
lasiby. demonstratting a lesel of plasma performance and detide lechnolugs comparahle whth thit

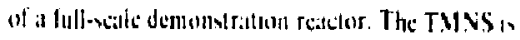
a veadr-abte [3.T hurnon! landem murror wilh

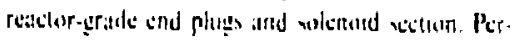

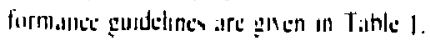

The ellettlecente part ol the atudy 4.1 . argantad into threc malas artils. the nickest

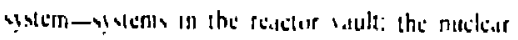

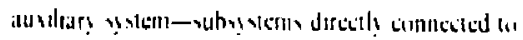

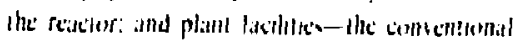
structurus ind nulliter.

TABI.E I, Performance guidelines for the TMISS.

- Sieady -atale, It-T burning landere mirnor

- Fevion-paner deavily $1 \mathrm{~lm}, \mathrm{~m}^{1}$ Hall badian

- $0=5$

- L tilip power requirencons 250114

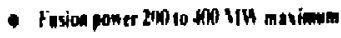

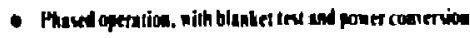
on abl-oms

- Rescios-stemani tectavolog: 121 mpercondurior 2001 Let' newrol brams I07) Cillz morronse pow er

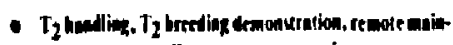

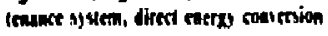


The nuclear system is the most complex and costly of the major systems and therefore wass the areil of major emphusis in this study. As seen in Fig. 3. the nucleur system consists of three principal units, the two plugs and the central cell.

Stastentig at the end of the micthinc snd working

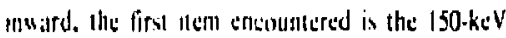

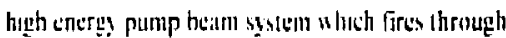

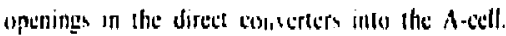
The diret conterlere are arrainged to intereept the

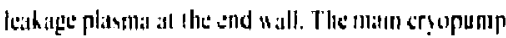

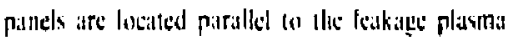
fan. Sir iaddinge tine panipung chanthor are the artags

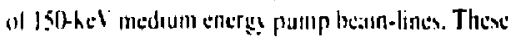

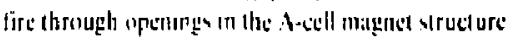

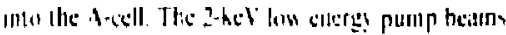

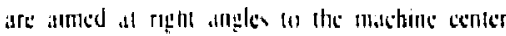

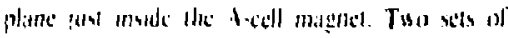

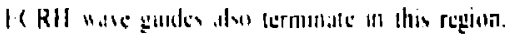

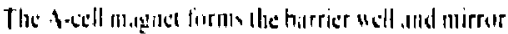

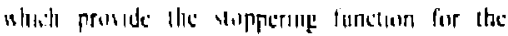
pla:m:a

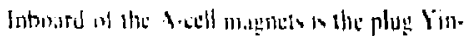

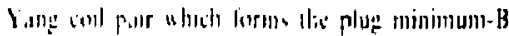

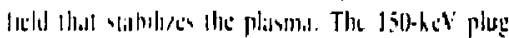

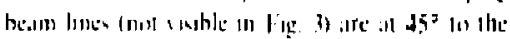

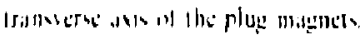

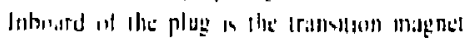

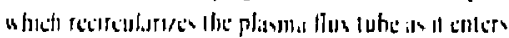

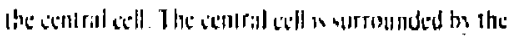

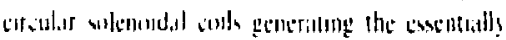
(liat lietd prodile lar sontomeng the larese contral cell pl:avmlat

1. Mechanical Engineering Deparmmest Technical Revirw. Lawrence Lisgrmure National Laboralory. Livermore, CA, Rept, \$0016-81-1 (1981). p. 75.
The entire interior of the matchine is lined with a cooled neutron shield. The cetilral eell also has space for a "reactor grade" power conversion hlanket. The outside of the machine is covered with shiclding to absorb any neutrons not captured interfally and to shicid the reactor vaula from gamma rays emitled from neutron-activilted internal structures.

The owtrall lengih of the robchiols is nominatly $116 \mathrm{~m}$. wish $618 \mathrm{~m}$ hetween the Yin- $Y_{\text {ilng }}$ cells. The

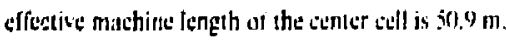

The engineering design problems are dominaled hy the magnets and the neutral heam systems. We have incorporalted $W_{h}$, Sn supercondector in the high field regions in anticipition of the sucecisful dewelopment of prictitial conductors for our complex coil shapes. The neutral heans require xereral new desclapments including comtinusus operation. nequatice ion acurces and he:am puriftes. tiont.

The performance rsiultin! inum the deogn is shown in our power flow dituratm. for the TMIVS

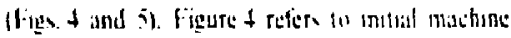
operation with no lhermal of direct energet

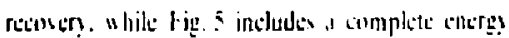

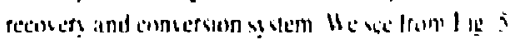

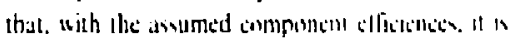

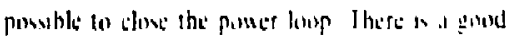

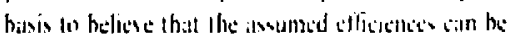
athieved on the MMIS time wialt

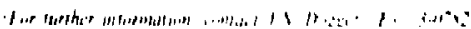




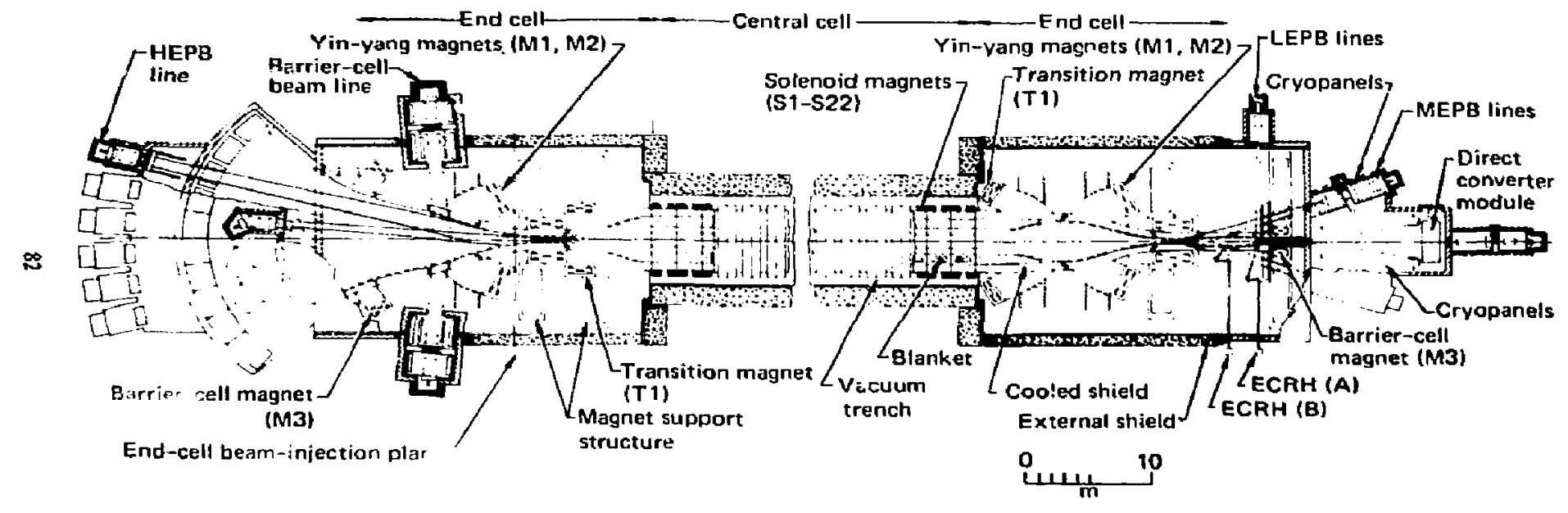

FIC. 3. The nuclear system of the TMNS. Magnet ideutification numbers are in parentbeses, e.g.. Yin-Yang magnets (M11, M2). 


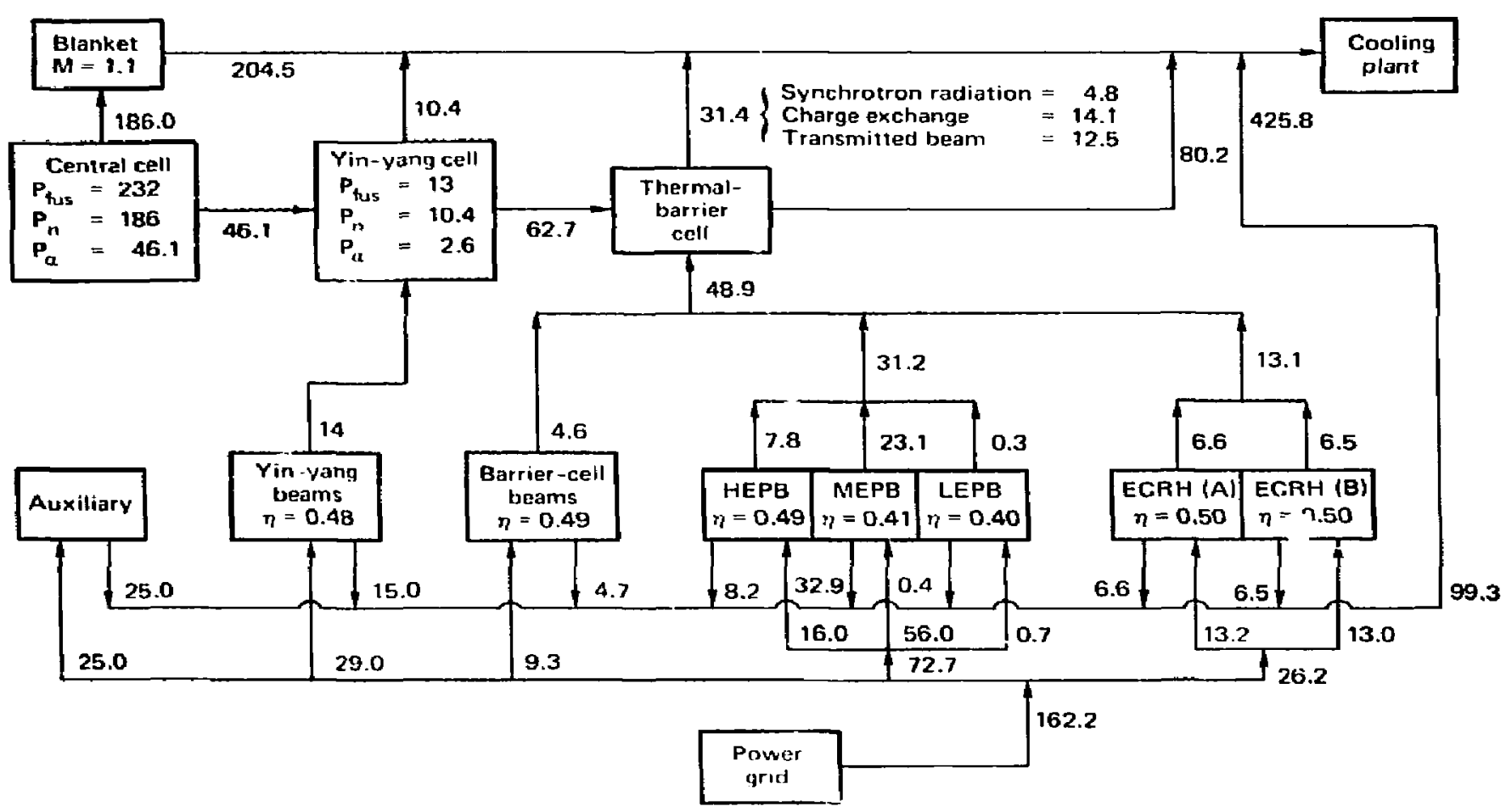

FIC. 4. Iower bulance for initial optration with nol poucr conversion. All puwers are in megawatts. Fusion

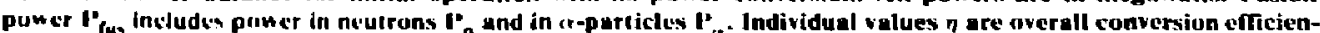
cles. and $\mathrm{MI}$ ts the neutron htanket mulciplication fuctor. 


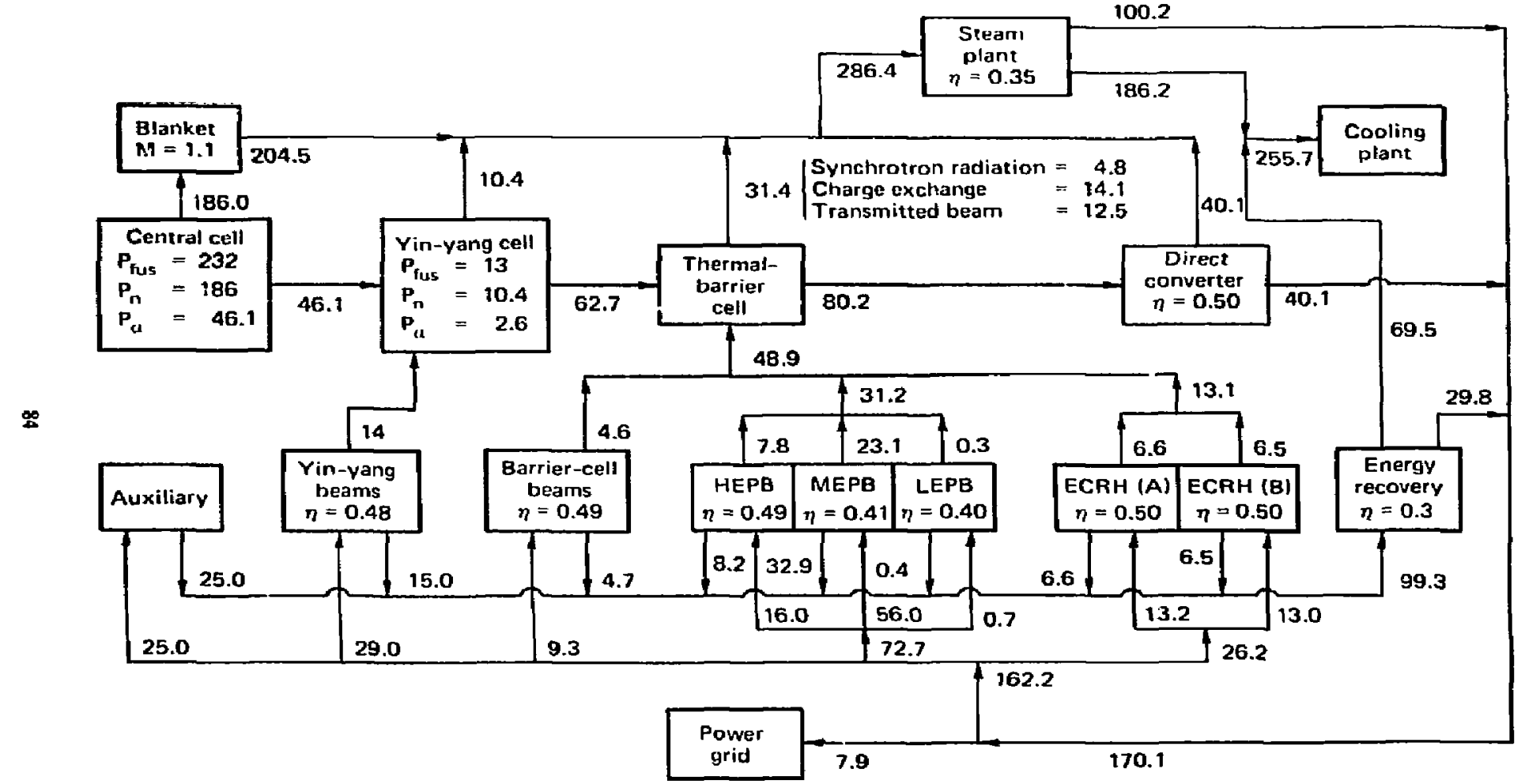

FIG. 5. Powes balunce with full enerey recowery and conversion. Symbols are defheed In captlon for Fig. 4. 


\section{MATERIALS FABRICATION DIVISION}

The Malerials Fabrication Division, a multidiscinlinary organization in the Mechanical Engintering Depariment, provides services thill are nol avaj) able from commercial sources. The number and diversity of L.LNL rescurch afforts make this Division ont of the Laboratory's largest. We buve ahoul $\$ 00$ hightl! skilled personncl and more than 3.700 pieces of eyuipment in our $\$ 13.5$ million insentory. Our laciliti ies ngrovide speciul capabilities in the fitids of optics, melding. racuum process, glass. plistics. shet metil, metil finishing, metrolcgy. prewing, inspectum, and atssembly. as well as conicmionnist and numbritullis controlled muchining of merals. high explonitess, and ceramies.

In-hususe fabrictution sersices are insilitible for all I.I.VI. propratills where reyuirements call for:

- Fibricaltun capahilities net readily

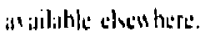

- Rapid lurnaround times.

- Hinuling of nialerials that are covis.

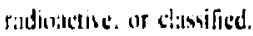

In uddellien. (he Division's fictilities are usted to

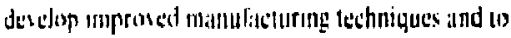

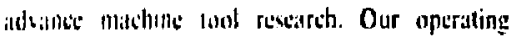
Fhiteroph? in th sallisfy the mechantical fubricution

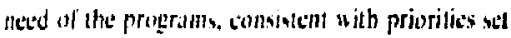
by thase proprams.

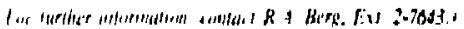

\section{Amcrican Welding Society Prescuts Awards to Two Members of the Matcrials Fabricalion Disision}

Charles E. Witherell, head of MFD's Metal Fiahriestion Group, wals awarded the James F. Lincoln Giold Medal by the American Welding Sociely for his papker, "Helding Stuiniess Steels for Strutures Operating at Liquid Helium Temperalures." Wilh Terey d. Rumas he Has also a 60 winnter of the Rene D. Wistermiln Award, which

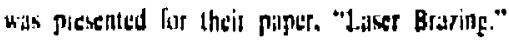

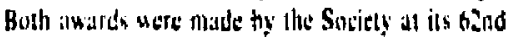
Annual Mctunk in April in Cleteland, Ohio.

Wiiluretl': m.jper was published in the Nonember 1989 issl ' wat Wetding gournill, and was belected by the A ths Awards Commillet as "...the greatest original contribution to the adyancement and use of welding in the year 1980." The work described in the paper demonstraled how to make welds in heavy-section stainless ster.ls that could withstand high operatirg stresses at exliemely low temperatures-only a few degrees above absolute zero $\left(-452^{\circ} \mathrm{F}\right.$, or $\left.4.2 \mathrm{~K}\right)$.

In studying the behavior of melds at these low temperutures, Witherell observed metullurgical phenomena not evident at walemer temperatures. These gave him clues as to why stainless sleel relds sften crack under certidin canditions. His study took 3 yeurs to complete and led him to rormulate a hypothesis for the euvee of this cracking, which has plagued the werding industry for some 50 years.

The results of tibis study. therefore. have a inofold beneft. First, they have demonstrated how 1o make sound, strong welds thal will withstand the rigors imposed upon structures that must withstund supercold environments. T'is capability is critizaliv needed for equipment that many of the worid's promising furure sources of enctg: depentis.

Second. a long-starding "elding revblem naa be well on the was w heing solved. Such a solution would improve the reliability of stainless stetel welds for literaliy thousands of apricusions frura power genterating glants (t) fuel tunks for sipscecruft.

The paper "Laser Brazing" by Witherell and Ramos was chosen by the AWS Awards Committee as "...the greatest original contribution to the progress and/or advancement of the use of brazing in 1980." Ramos is supervivor of the l.aser Metolworking and Process Facility in the MrD.

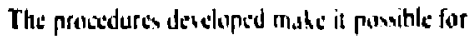
the firss time to join metal pitts thinner than a human halir with neglegthle best mpul. For many applitations involuing microparts in the dectronis. medisins, and compuler fields, otdinan mithods of joining melals, like welding snd hrsing. are too hot

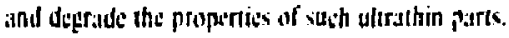

In the lesser-braring nethod, the lesitr concentrats the hest needed to melt and flow the heasing filler metol (ususlly an allon of silh cr and capper) in the juint. Under ibe pulatd liner thesm, which lists anl 10 no pur pulse, a thin rithon af the brasing liller metal is melesed and wets nut acroms the very narrow gatp letweton the motal hoing joined. mush the " yy thutler wats a frutng pion. When the luset

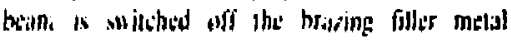


solidifics, forming a strong metallic bridge across the parts.

\section{Laminar-Flow Dampers for Stabilizing the Behavior of Pneumatic Vibration lsolators*}

During development of the 84in. diamond turning machine at Lasurence Livermore National Laboratory, we modified a commercialiy available pneumatic isolator by including a laminar-flow damping system to isolate our precision machine from ground vibration. We devcloped a configuration of altutinum plates separated by shim stock spacers and substituled this for the usual orifice. flow restrictor for the gas flow in the damping system. This new systcm gives a leveling response within two seconds and precludes continuous oscillation for the full range of rtotion amplitudes of interest.

Precision machine tools and measuring machines normally require isolation from ground vibration. with a low natural frequency for the isolator/machine systern. But such a "soft mounl" could illow the muchine to tilt along with its chinging load, if there wer not also a feedback system or some self-leveling valies to maintain level. The springs that isolate the machine require some damping so thit floor molion which occurs at the resonant frequency will not be unduly ampirfied.

Commetcially aviliable isolators employ a pneumutic spring. Damping is provided by dissipating the energy of a compressed gas through a restrictor into an auxiliary volume. An orifice typically joins the two volumes. However, the damping of in orifice is nonlinear, with the sesistance increasing with amplitude of motion. Therefose the orifice size chosen is only of optimum dumping value for a single amplitude. We found that in a self-leveling system with orifiec-dumped isolutors, some aritiplitudes of motion have such poor samping that the feedhack can render the sybtem unstuble.

\footnotetext{
-Dr. Duniel B. De hru, uuthot of this cummary, is a peofector of ateronuutical und aslianulicul enginering at Stunford Universily. The work *as performed when the will a futrmer em. ployes in $\$ 8$ ho.
}

This problem became evident during development of the 84-in. diamond turning machine being built at LLNL. The machine (Fig. 1) will requise fast leveling. The spindle slide on this machine wili weigh 10 tons and will move through as distance of 42 in. at speeds up to $15 \mathrm{in} . / \mathrm{min}$. Relatively high gain (gas flow in response to change in height) must be employed. When the isolators for the 84-in. machine were first activated, this high gain resulted in a limit cycle (continuous oscillation) of the 80-10n granite base with in amplitude of neusly 0.040 in Thus vibration isolation becume it secondary question until the limit cycle could be corrected.

A eontrol system can be stabilized by a varicly of techniques, and in the case of the diamond turning machine, passive damping was sufficient. We achieved this by replacing orifice damping with a laminur-flow restrictos which provides constant resistance to now throughout the amplitude range of inturest.

The restrictor must operate in laminar how with a Reynolds number below the transition value of 2,000 . We found the performance of our devices correluted well with theory when we restricted the flow to values of 500 or less. Capillary tubes were not suitable since they must be excessively long or too greal in nurnber to satisfy the joint requirements of optimum flow resistance and low Reynolds number. Paradilel plates have worked well, and they ean he puthaged in a !waiely of ways. Adequale flow cross section in saltisfy the Reynolds number requirement was achicied by stacking plates of aluminum and straraling them by shim stock spacers. The spacing chosen is typically in the range of $0.004100 .016 \mathrm{in}$. Figure 2 shows the arruggement of the parallel plates. Figure 3 shous the isolator in. stalled urider the mathine.

Figure i shows the compurison belween orifite-flou and lamiliar-floy damping. With orifict damping, the system oscillatci continuously. Data are shown at two loestions to indieate the rocking behavior. The osililation could be stopped hy means of low-gain level-sensing valses, but the penally wass a leveling time in excess of 2 min. By conirast, with the lautinar flow dampers and highgain level-sensing valves installed. the transient sesponse to a man sleppring on or off the edge of the maschine is less than lwo seconds.

With the oscillation problem undite control. the isolators perform well. The vibration level on the 80-10n granite base is less than I $\mu$ in. in cither the 


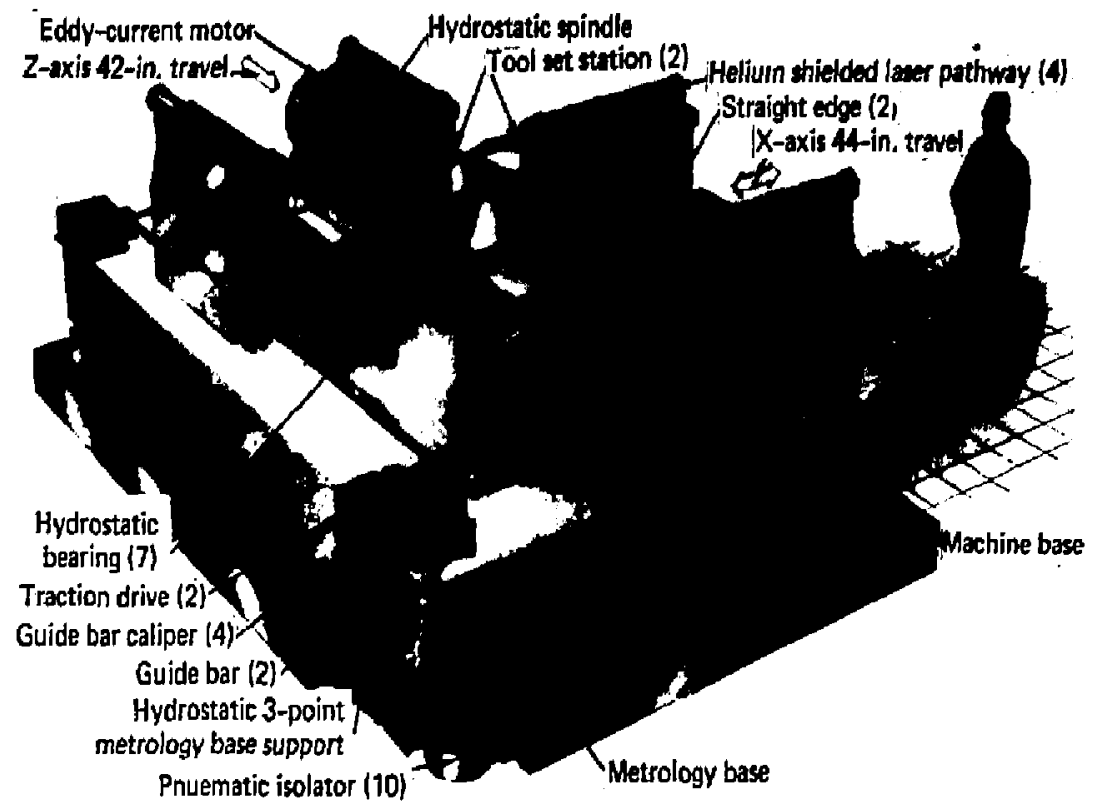

FIG. I. The newest diamond turning machine being built at lawrence Livicrmore National Laboratory will use laminar-flow damping in the preumatis isolators.

verticas or the horisontal direclion. The noor vibealion is 10 to $15 \mu$ in. at 15 to $22 \mathrm{H} /$.

A few pieces of thes mowit and shim stock holed together and installed insice the isolator have changed the hethatior of the jiolator system from

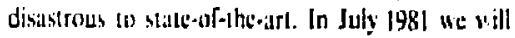
istue a lull report giving the detitiled design tequations.

The autho: wishos to acknowledge the assistance of the following members of LLNL's Metrology Group who helped to bring this project (1) il successful conclusion: Jim Bryan, Don Carter, Dick Clouser, Jim Hamilion, Richard Warner. Chuck Wouds, and Ail Caraveo.

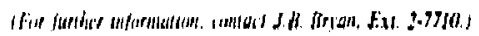

\section{Flectrochemical Joining of Dissirnilar Metals}

The chise advintigle of joining hy plating it that it is dolls at rount atenposatuse, thus sliminating shrinkage sireskes and distorlions nor. mally associated with higher temperature joining methods. Another advantage is that properties of componem materials do not change. It is an amazingly strong method of joining dissi.:iar matcrials.

Although must of the sork repurted here is the resull of experiments performed at Sandia Yutional Laboratories, Livermore. LLNL is cunlributung to the continued ust and expansion of this process.

Joining by pating allows . atrels of similas and dissimilar metals and alloys to be juined. Suc. cessful joints include aluminum to stainless steel. aluminum to copper. beryllum to berwllium. beryllium to stainless stecl, and illanium to

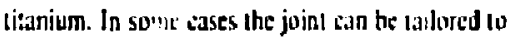
meet specific destgn requitentents.

Electrochemical joining consists of machining a taper on parts to be joined. Then they are cleaned and mited. The triangular segment between the tapered edges is built up by electroplating hefore the joint is matinined to final tolerance.

Usually parts to be jointed alfe mithinged with a liper of at leasl, and preforahly greater than, 

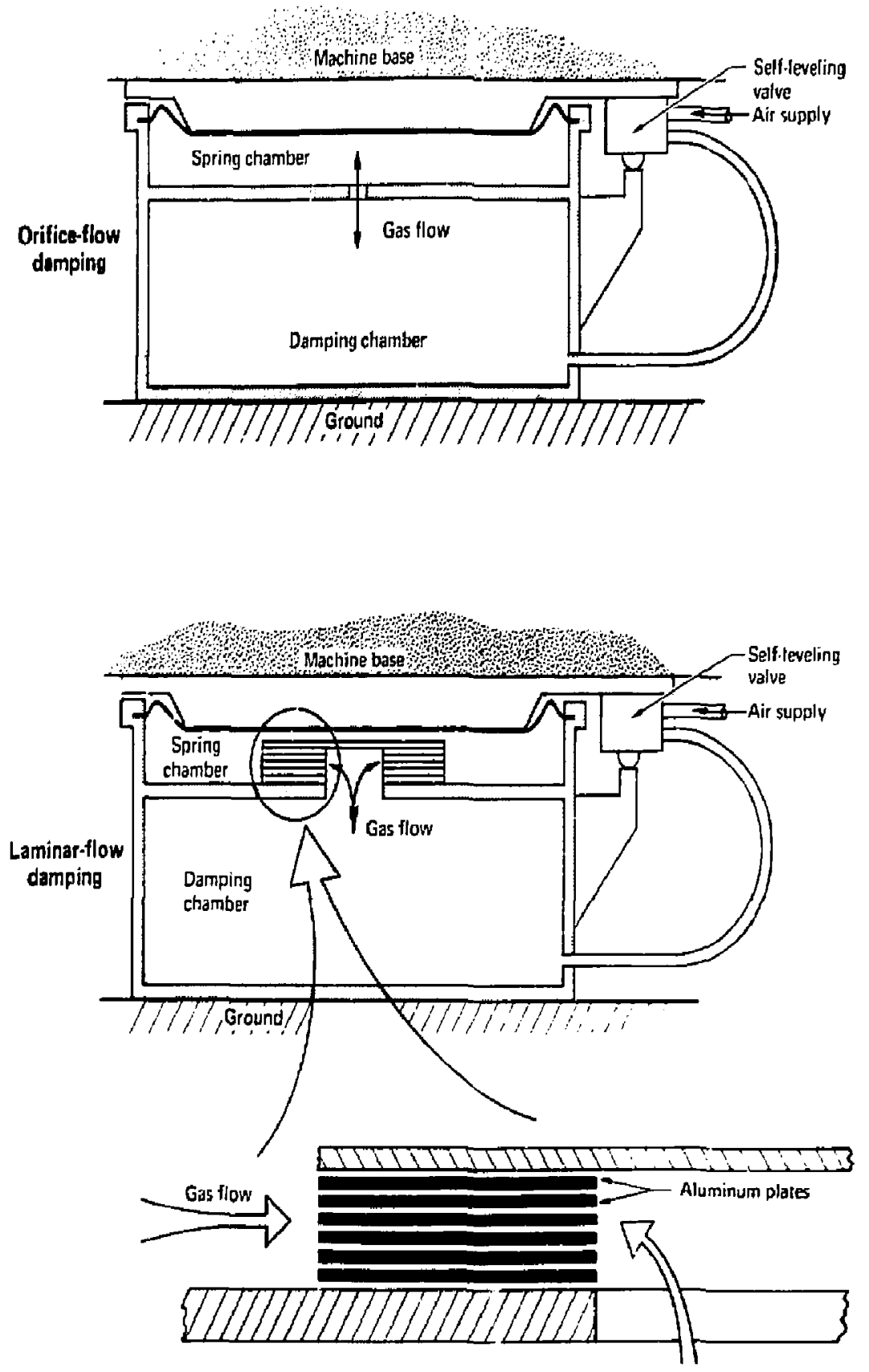

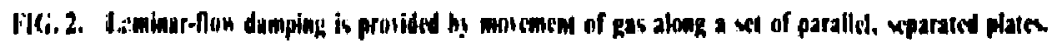




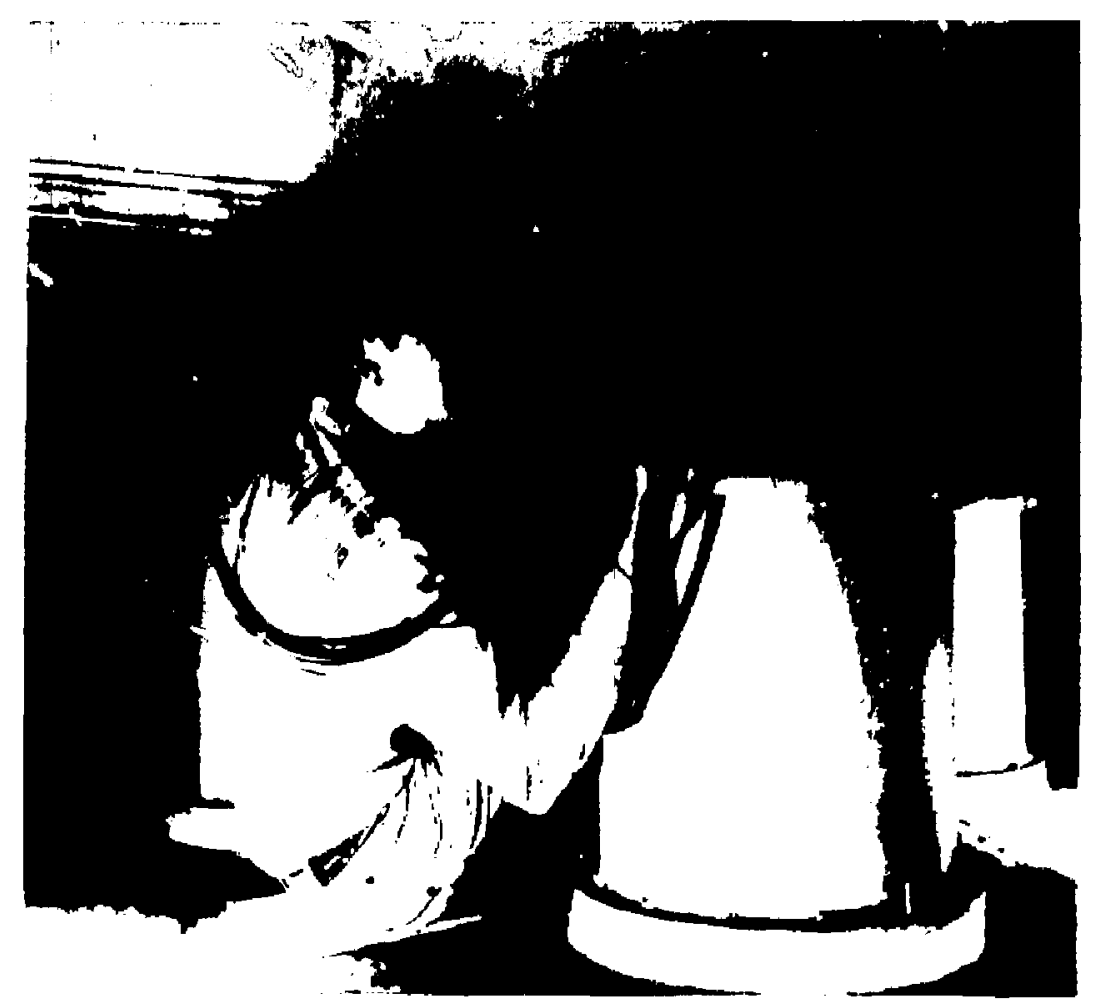

H1(;. 3. The pncumatic isolatur nill be one of 10 in place under the 84 in. diamond iurning machins:

120 dete Tapers of less thill 90 dege should be

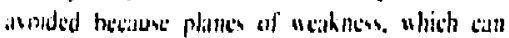

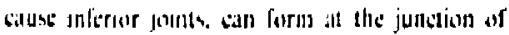

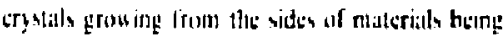

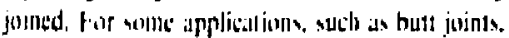

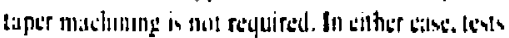

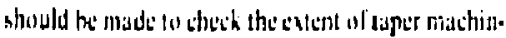

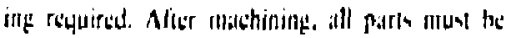

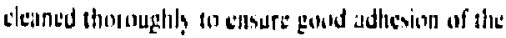

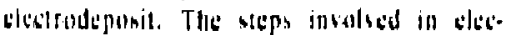

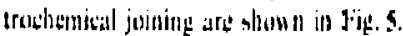

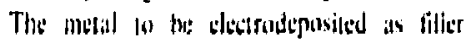

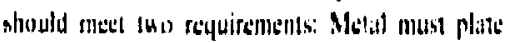
adhitrenly on mals rials to be joined, and filler

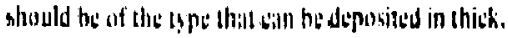
whorem deposils. Malcrials blectonleposiled mons

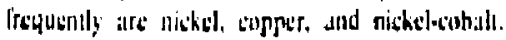
Many other intials, intluding silter, gold. iron. 4in.

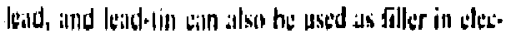
Irocherintilil juining.

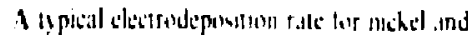

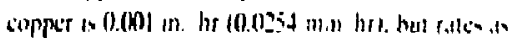

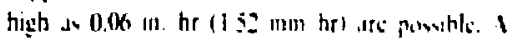

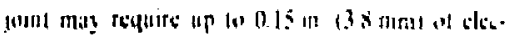

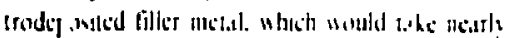

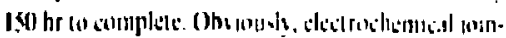

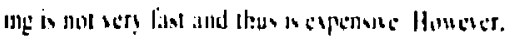

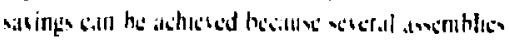

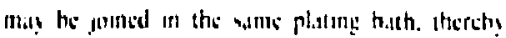
robutuly the seme por asembts.

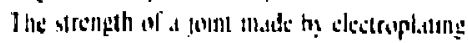
depende an the serength af the elecirodipanited

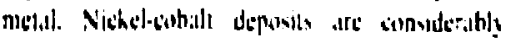

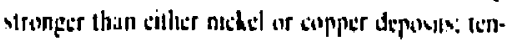

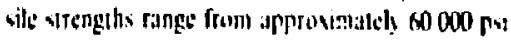

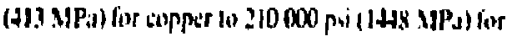
nichel-aubjalt.

The tenilte stength range of various clecIrodeperits is given in Table I ff the clectrodepunit is the stipkes! link in the joum. substitution of 


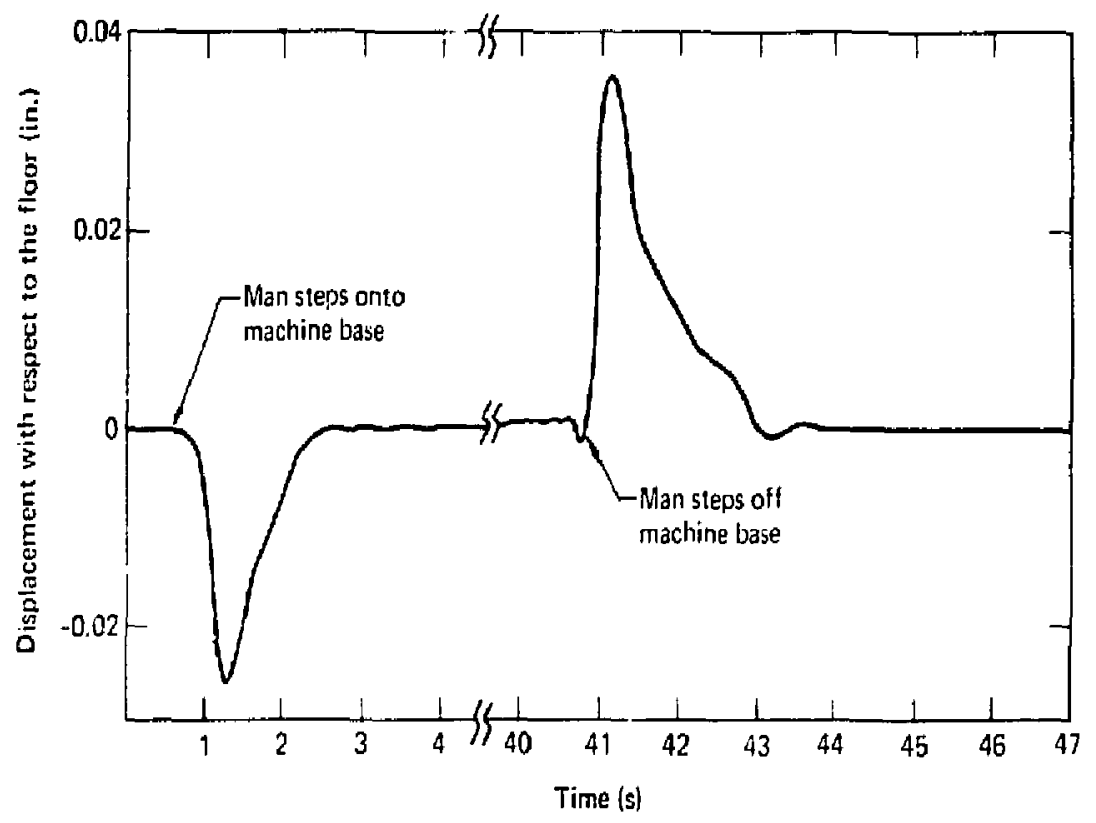

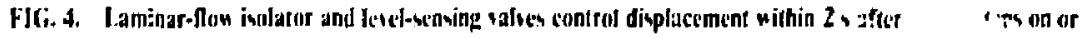
off the mathinc.

TABI.F 1. Tensile strength of electrodeposils used for joining.

Metal
Coppert
Mirked
Michedrobalt

Tensile strength. IING pis (NIP)

H2.

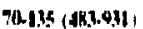

|211-221: 4 827.1517 ,

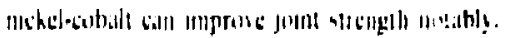

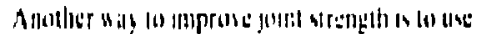

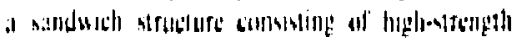

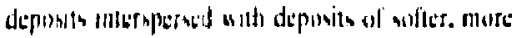

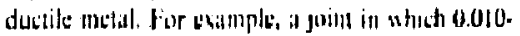

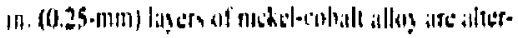

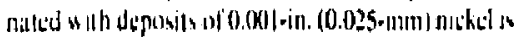

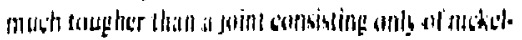
colball.
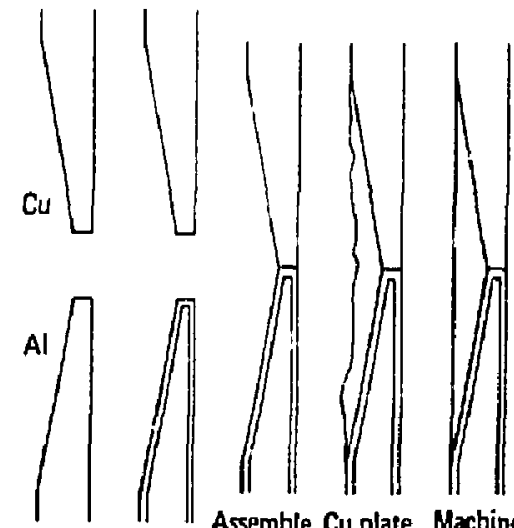

Machine Cu strike

taper on Al

FIG, 5. Fire seps in eloctroctemical joining of ow per and aliminum. (Courtesy of Sadia Salional I.sboratorio, Livermore.) 
Electrochemical joining is confined largely to more exotic structures used in the aerospace and nuclear fields.

The process does not lend iself to large-volume production applications. Some of the material combinations joined by electroplating are listed in Table 2 .

Electrochemical joining can be used to join aluminum to solid or hollow round sections of copper or aluminum plute to copper plute. The advantuge of electrochemical joining for this metal combination is that resulting joints ase more resistant to longuterm aging at high lemperatures than joints produced by more conventional meuns. For example. a percussive arc joint at $392^{\circ} \mathrm{F}(473 \mathrm{~K})$ hecomes britte after approxinuately 1000 to $2000 \mathrm{hr}$ of uging. A cold pressure-sweided joint becomes brittle after only $20010300 \mathrm{hr}$ of aging. On the or her hand. coppur electroplated joints belween 2024 al uminum and solid copper withstiond expusure $10420^{\circ} \mathrm{F}$ ( $488 \mathrm{~K}$ ) for $150 \mathrm{hr}$ withoul degradation.

Plating can also be used to join unusual shapes. Figures 6 and 7 show two such examples. Figure 6 is an issembly of at 4-in.diant (101-mm) alurinum sphere joined to an aluminum cylinder of approximatcly the same diameter.

Electrochemical joining is usco to join 39-in. $(0.99-\mathrm{mm})$ rings of $6061-\mathrm{T} 6$ aluminum and $\mathrm{AM}-363$ stamless seed. Figure 7 shous the steps in the process and the finished part. The redson clecIrochemicul joining was thosen for this applicution is that it is the only method whereby the aluminum relains its T6 condition after joining. Nickel is the electrodeposit.

TABLE 2. Metal combinations joined by electrodepositing.

\begin{tabular}{|c|c|}
\hline Mistal comblention & Electrodepsil \\
\hline Aluminum to scalalesw sted & $C \omega, \mathrm{Mi}$ \\
\hline Aluminem to contt; & $\mathrm{Cu}$ \\
\hline 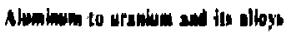 & Ni \\
\hline Derthenem to berylliwn & NI \\
\hline Merglliwim to tieel & $\mathbf{N}$ \\
\hline Sied lo ched & Co, $\mathrm{nil}, \mathrm{Nit}$. \\
\hline 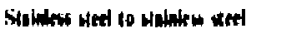 & $\mathrm{NH}, \mathrm{NHF}$ \\
\hline Tilentwe to titsing & $\mathbf{N}$ \\
\hline Tileming to uracium albyb & $\mathbf{N i}$ \\
\hline
\end{tabular}

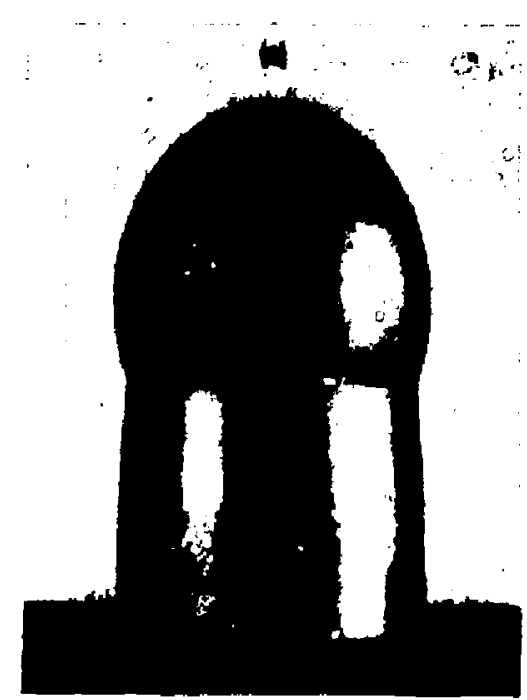

(b)

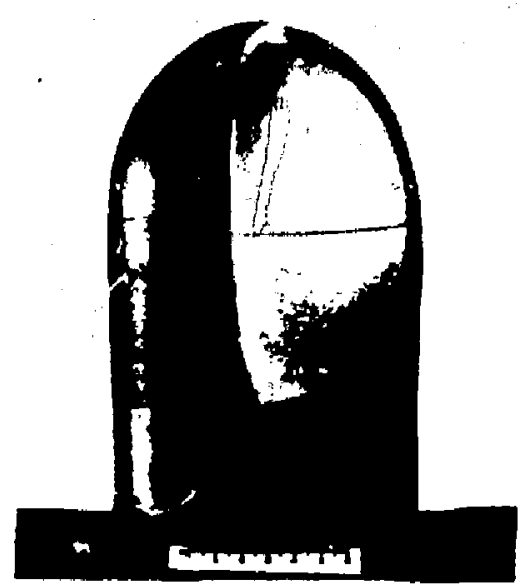

FIG, 6. (a) Muminum sphere joined to aluminum cylinder by plating. In scctioned vien (b), note the long laper machined on the cylindrical portion of the assembly. (Photo, courtesy of Sandiz National Laboratories, l.ivermore.)

An amiaring demonstration of the strength of a joint made by this process is given by the test to fallure of a sted ring (AISI 4340) jwined to a highstrengih U-Ti ring. Fip̧ure $B(a)$ shows the -ing before the compression Pest. Fiugure $B(b)$ shows the fijilure. Figure $B(c)$ is the cross section of the failed 
(a)

Ople with thin copost (0.0000 in.)

(b)

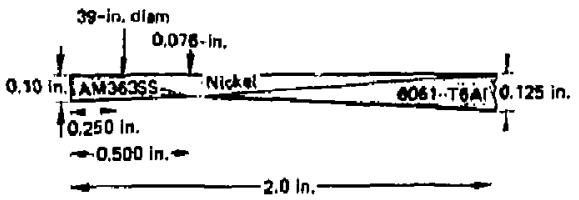

(e)

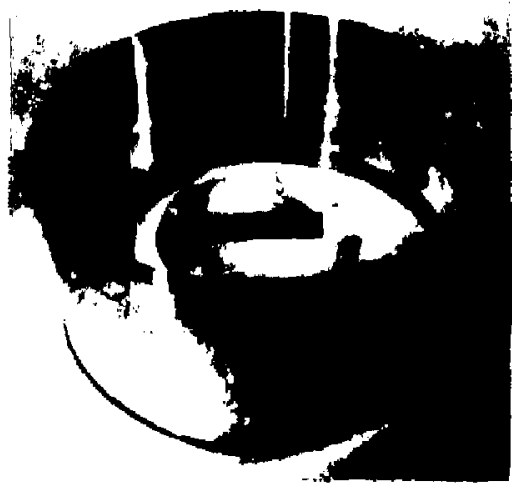

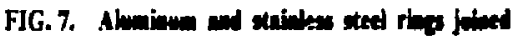
by electrudeposition: (a) tepa in the preces of $j$ in

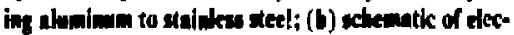
troplated joiat; (c) a rmiched part.

Wall: note that the failure is outside the joint. The joint was nade with $60 \mathrm{Ni}-40 \mathrm{Co}$ which bas an ultimatt strength of $220000 \mathrm{lb} / \mathrm{in}$. $^{2}$

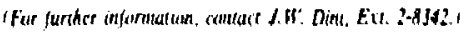

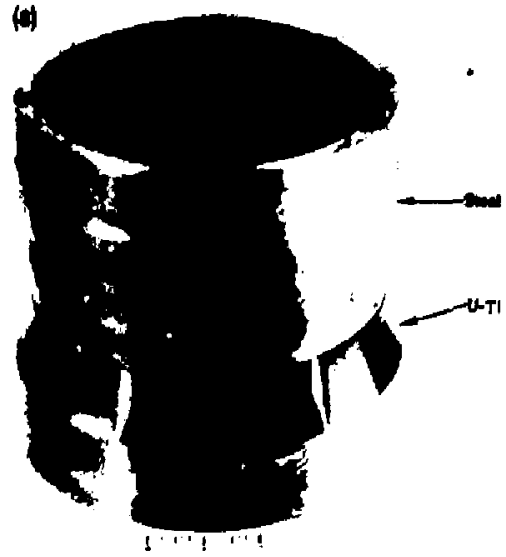

(b) $500,000-1 \mathrm{~b}$ compressive $110,000-16$ torque
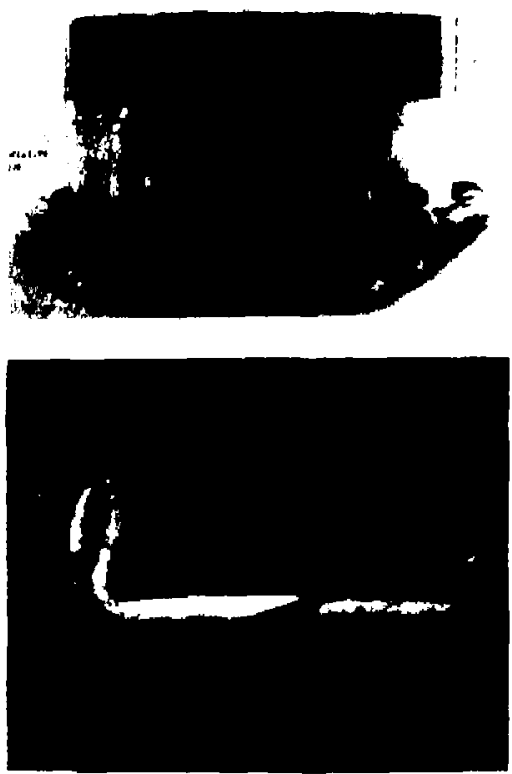

FIG. 8. Exasple of a sted sraving joint wefore and ster compresion textion to foilure [materits ase

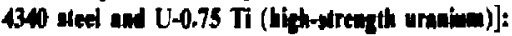
(a) before, (b) after, wat (c) joint crom section. (Ptoto, coertesy of Sadin National Laboratotics, Lirengere.) 


\section{Joining Diamonds to Molybdenum for Diamond Turnivig}

Fastening and shaping diamond gem stories to the end of an industrial tool is a closely held art. Some consider it a trude sectet and will nol publish on the subject.

Our suppliers produce high quality tools and there was little reason to become involved in the fabrication details. Until now the purchased tools have been quite adequate. The diamonds on these tools are bonded to their shank mechanically, in the same way that a silver filling is bonded to a tooth. There is a limitation, however, on how small the tool can be made beciuse of the necessiry depth of the "filling." A new requirement for very small tools has forced us to adopt the brized-oul tech. nique uhich some manufarturers have been using for the past 15 years. We knew that it wes important to match the coefficient of thermal expansion of the shank to that of the diamond to avoid cracking the diamond. Nolybdenum is a reasonahly close malch. Using experience previously developed in the Vacuum Processes Labriators (VPL), a smell dia. mond itas joiked to a moljbdenum shenk by vacuum hrazing. Ticusil. a tilanium-copper-silver alloy. was used as the hrase material. A small piece of $0.002-$ in. foil was pliced under the diamorid. The diamond uas precisels aligned on llic slatok and was held in place b! a 0.004 -in.-diam lungste spring.

The asernthy was placed in a radation-lypo basum furnate and batad at al temperature of $609^{\circ} \mathrm{C}$. The batcum wa held is $2 \times 10^{-}$Torr.

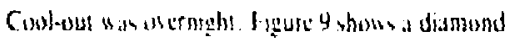
brared to a low thank, ane of the first lo he honded here al the latahordtors

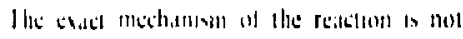

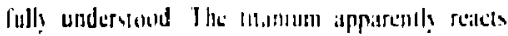

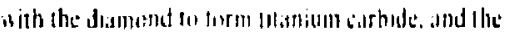

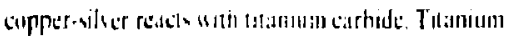

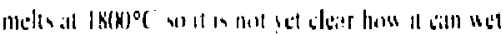

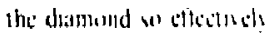

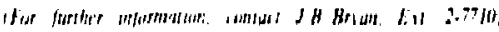

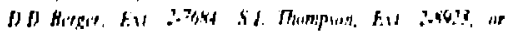

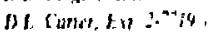

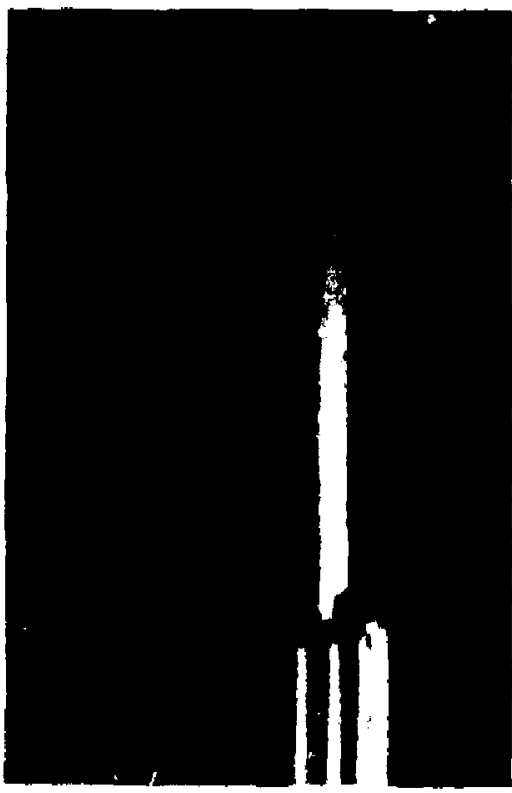

FIC.9. A dhanow brazed to a tool shak.

\section{Jon Plating of 304 Stainless Steel}

Preliminar! iludies of magnetron ion plating of

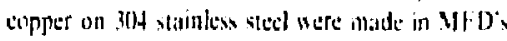
Vaceum Processes Latharalary. The purpose al the studs was 10 desermine whelles or not the oun plitting process. esupled with it mistretran uould. in Eat. produce a uniform coitlong that athered an

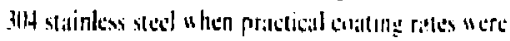

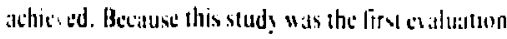

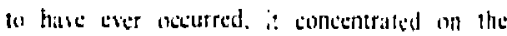
relationship of uniformin and adherence ratc is at function of pressure. The work lo dite shows that at deposilion ralle of aboul $7(x)^{\circ}$ a min at the oplumuss ntessure for unifornsity and atherence is pussihle. The coatings nere produced in the test apparatus shown in Fig. jo. The slart. Table $:$, sous the toitinge enilurmity altained al hariou, pressups

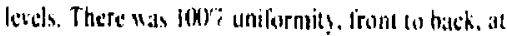
holh 20 and $27-\mu \mathrm{m}$ pressure, and at the specific source and suhstritte voltage levels shown. It should be noted tlast the lob"i uniformity on a cylinder is an indicalion of uniquentss of this protess

Ring shear kests were porformed an a 12.6-inindiam rood to proside a quantiritatio atcatns of 


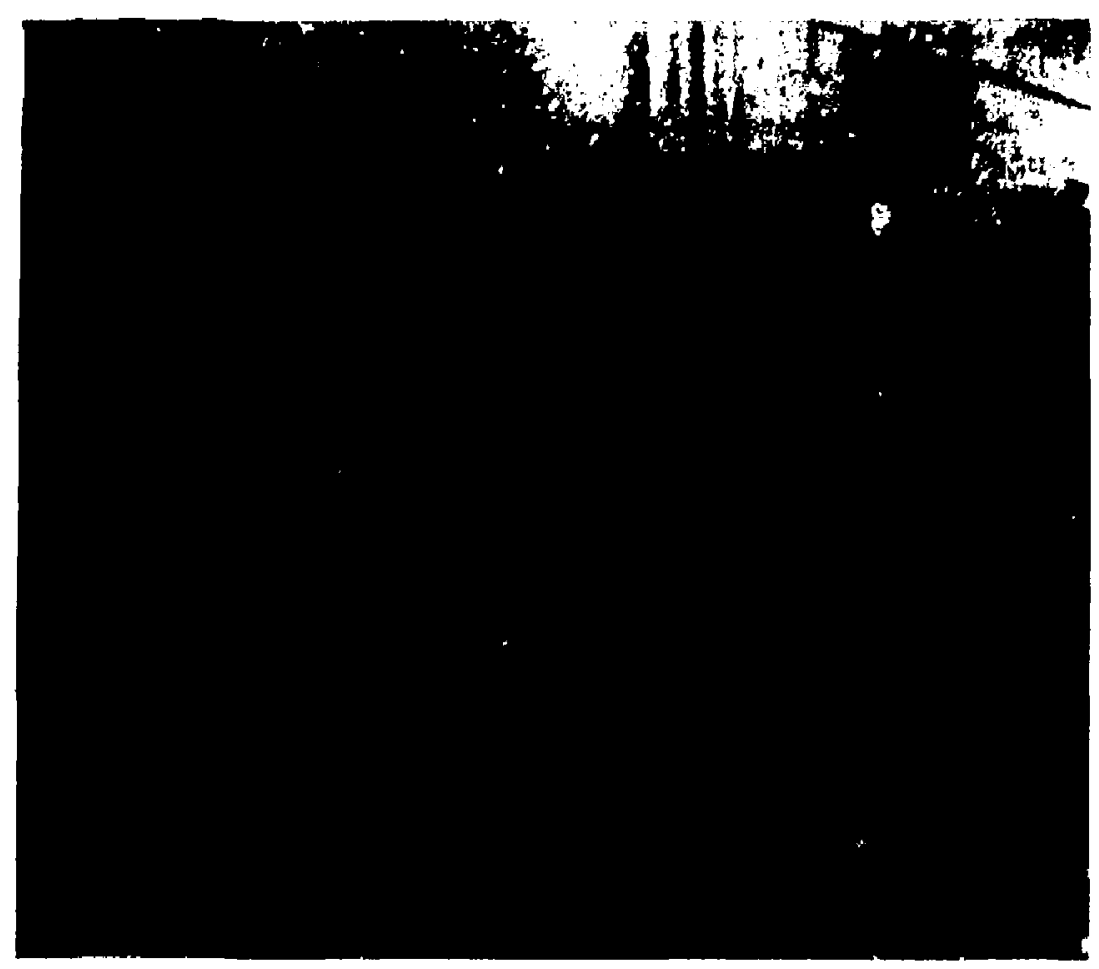

FIC. 10. Maghetron ion-pinting test cell.

TABI.E. 3. Liniformity and rute is pressurs.

\begin{tabular}{|c|c|c|c|c|c|}
\hline \multirow{2}{*}{ 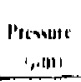 } & \multicolumn{2}{|c|}{ Wh } & \multicolumn{2}{|c|}{ Thiskne ts Ik fi } & \multirow{2}{*}{$\begin{array}{l}\text { I niformit!" } \\
\text { Front/Rack }\end{array}$} \\
\hline & Sinura't' & Substrati' & Fина & Bach & \\
\hline 5 & 11.34. & I.6h & 35 & 7.5 & 21.45 \\
\hline III & 0. $7(x)$ & 0..5) & $\mathbf{z}$ & 5 & $25 r$ \\
\hline 211 & I) सात्रा & O.BO & 20 & $2 i$ & $\ln (x)$ \\
\hline 27 & (1.3.3). & 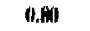 & 1.1 & 1,3 & lowir' \\
\hline
\end{tabular}

motasuring adhesum. The ring shear test consists of ion platent a sopper ring on the 12.6-mm-dian pin. then instrising 1 lis ang thickness by conventionas sectronlating tedmigues. This thicker ring nem :llows a shoidder a bo mathined on the pin which. in lurn, can be combusitsely driven off in the fixturt shown in lig. I (a). Tle pin configuralion prior to instrion into the linture is slown on Fig. I1(b).
A ring shealr lest of al coatling denowiled ali op-

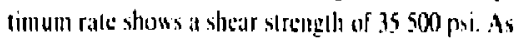

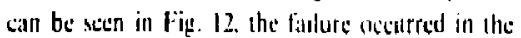
6.Jpker deposit and not in the ion-plated cop. ner/stainless sted inlef [atect. Figure 13 is a loat-time curve for the lest of the sample shown in Fig. 12.

$A$ sunimary of this uniquat work was prosented to the Ameritan Vacuum Socitety in Los Angeles on 


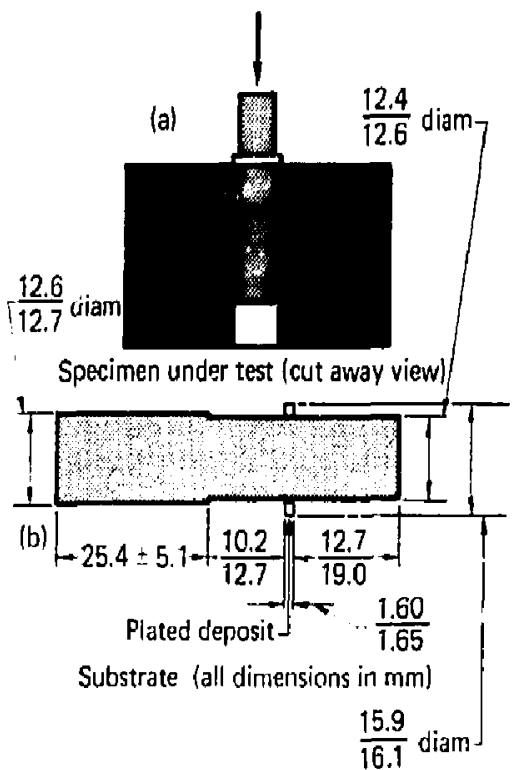

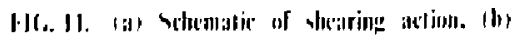
upicist ring sarar pin.

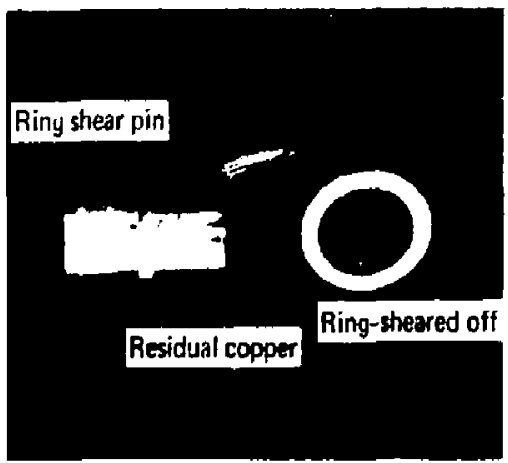

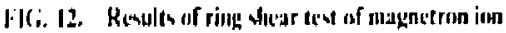
plating af topper. Vote: fuilure occurrett in the coulientiunat platerl copper.

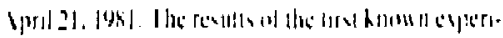

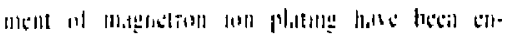

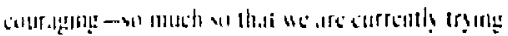

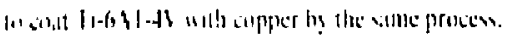

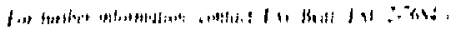

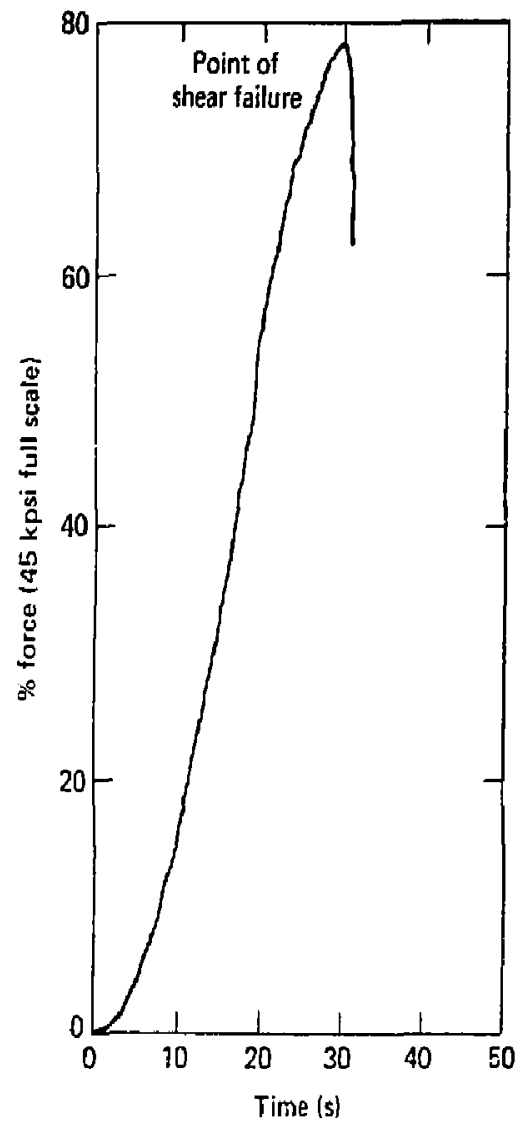

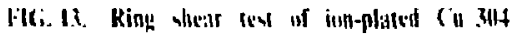

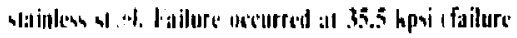
nutula- -101 :

I. J. W. Dini and H. R. Johnson, Electrochenical Soming: Procers, dpplications, and Property Dolu. SME Technical Paper ADT\$-855 (1975).

2. J. W' Dini and H. R. Johnson. "A Case History of Joining by Plating Applitutions," in SA.MPE Qtearter!! , Azusid, CA. July 1976.

3. J. W Dini and H. R. Johnsun, "Joining by Elociroplating." in Afelals tngineering Quarterdy, Matals Pith, O, Itbruary 1974. 


\section{PUBLICATION ABSTRACTS*}

H.P. desso, On the Instabilities of an Exvernally. Lnaded Shatlow Spherical Shell. Liwwence Livermore Nittional Liboratory. Litermurc. CA. Rept. UCRL-85180 (1980). Prepared For Nuslear Engineering and Dusign.

The simple von Kirmuin nodel of a clamped shallow clastic istp subjected to external pressure is

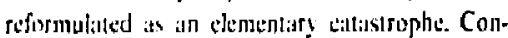
eteptual anderstandine of load denlection bethatior is subatastlialls improsece is at result. Three distinct modes of dellection bethavise are identified. Onc snap-shrough tupe behavior is substintiated by comparion (1) experimental dialt.

C.M. Bacigalupi and W.A. Burton, Modd Testing of

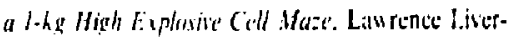
more Nationial L theraturs, Likurnore. CA. Repl. LCRI..31) $2 \vdots(\mid 981)$.

The b.apiment of the prophened High Explowives

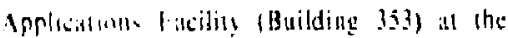

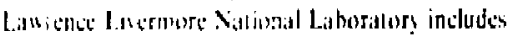
wetal coplonete ter cells for the assemble and or vorige of up to lo $\mathrm{kg}$ of high explosire (HE). This

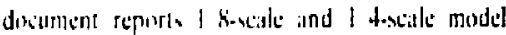
tesh cunduciet la comlirm mile design criteria. to

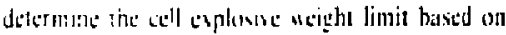
all allow.

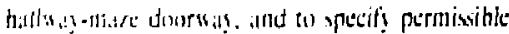
arest lur h.snd'sn! HI: within the cell. The integrity

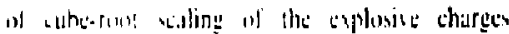

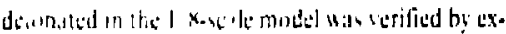

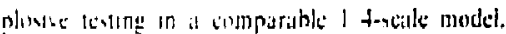
Refleted whech presures on the ballwat adjacent to

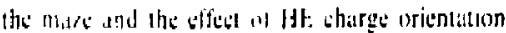

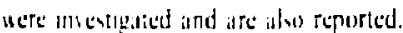

T,H. Batetr, K.E. Patrick, and H.R. (all, $A$ TSTA Componend Crropump. Lansente Livermore National Latoratury, Lizcrmore, CA. Repl. UCRL-k4t56 (1940), Preparted for the 27th Annual Symp. Amcricin Vidcunn Soc., Delivit, MI, OcWher 14-17. 19k!).

The Tritiuns System Twat Asuembly (TSTA) at the Les Alames National Laboratory is intended to Jemonsilratt realissit fust supply and cleanup stenarios for Future fusien reactors. The valcum pumps must be capable of handling latge ciuantitjes of reictor exhaust gases consisting largely of mixlures of hrdrogen and helium isolones. Cryocondensing pumps will nol pump helium at $4.2 \mathrm{~K}$ : while crsusorption pumps using molecular sieves or charcoil halve good helium pumping specd. the adsorhenl clogs with condensed hydrogen while pumping mixtures of hoth. $A$ solution to this problem is a compound design whereby lhe first slage condenses the hudrogen species and the second. or sorptisn. stage pumps the helium. The TSTA pump designed at Lanrente Livermore National Liboratory uses argen pas to eryotrap the helium in the helium. hydregen mixture. The argon is sprayed directly unto the $4.2 \mathrm{~K}$ surfice all a rale propurtiontal to the helium flow ratte, purmiltung contisuous pumping of the hellitmistidrogen mixtures in a single-stage pump. Heweser, the possithilit? of differential desorption als a lirst stage in the TST A gils stpira-

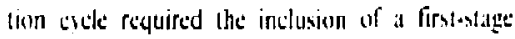
hydragen isotente condenter. The desilin. perfor-

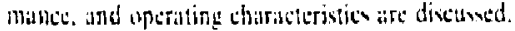

D.I. Bernreuler and D.H. (hung, De'stupmem oll

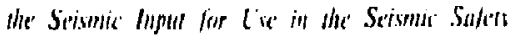
Margins Restardh Progran:, Lawrence Livermore National Laboratory. Linermort. CA. Repi. UCRL.84197 (1981). Prepared for the toth Intern. Conf. on Siructural Mechisnics in Resactor

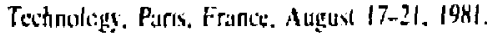

To chillualt the consers atism in present reactor seismic deripn techniques, a prohabilistic halsel systerus noudel is being constructed. This modsil will be used to estimalle the probability of a seismically induced radionctive relestse. The sistems model requires as input a probabilistic definition of the seismic halas in suitable form for a site located in the cistern part of the United Stales. Estathlistiment of the seisnic harard all a site st made in terms of the annual probability of exceeding a given ground motion patrameter. Difficullies arise in the probabibilistic

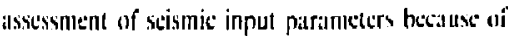
the signilicant uncertainsicis assoniated with the carthuvake eccurrente model and the ground mos. tion madil including attenu:tlun relationships. Wo

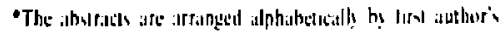
nimk. 
descrithe an overview of aur anproach to deal with these wneraintits and ovalualt the scistnic hitard at a sive foculed in the eastern United States. In par. ticular, we discuss our experience in the use of ex. pert opinion to supplement inudequate datu sets to arrive in reliable estimases of exceeding various lesels of ground motion. Some cramples ate provided to illustrate our approuch.

D.R. BerHald, J, ., Maniscalco, J.M. Z,ee, and R,W. Moir, Fircim Suppresied Tandem Mirror Hibriá Reactur Optiems. TRLi. Ins.. Redondo Bewct. CA 90278. Prepared for Pros. Fourith ANS Topical Mesting an The Technologe of Controlled Nuclear Fusion, King of Prusia. PA. Oaloher 14-17. 1980

The design fessibility of screrat uptions for a fiswion supporessed landoon mirror hybrid resctur

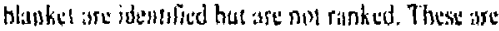
basid upon 7 a d a more tadial rones incorperating a monfiswion newson multiplier cone and a fissile

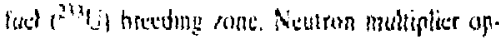

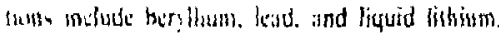

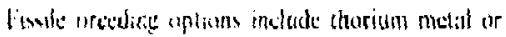

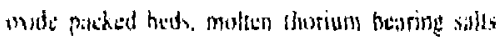

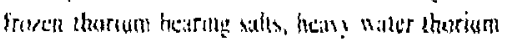

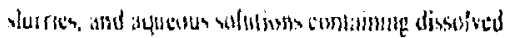

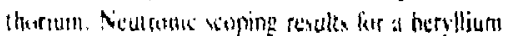

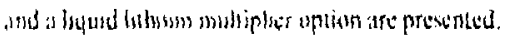
There are compared with a retorence desien

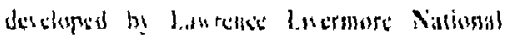

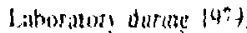

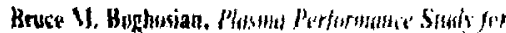

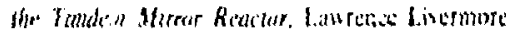

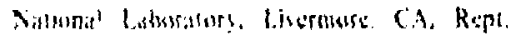

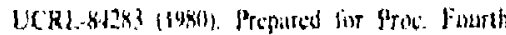

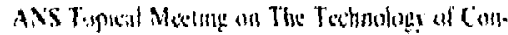

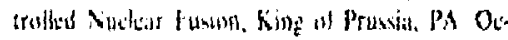

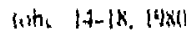

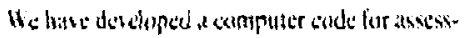
me bie performance of the variations on the thes-

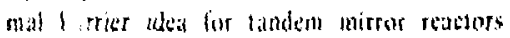

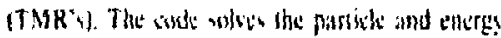

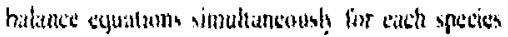

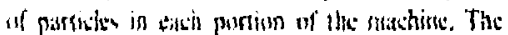

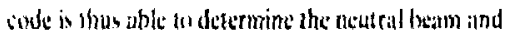
ECRI injertion puesers that are reysised on suslain

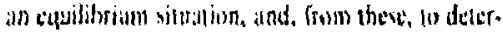

mine the inachine's Q value. This paper focuses on the methodology and numerical algorithms used in accomplishing this sotution. We pian to use this code to compare the A-cell burrier TMR with axi. symmetric TMR's.

S.E. Bumpus, JJ, Johnsom, and P.D. Smik, Best Estimate is Etaluationt Hethod Seisntic (B-EMS): An Intradution and Demathiration. Lawrence Livermore National Lisborstors, Livernore. CA. Rept. UCR -84193 (1981). Picpared for the 6th Inkern. Coni. an Struciural Mechinics in Reactor Technology. Paris, France, Augus 17-2', 1981.

The stismit andlysis and design of a nucleat gower plant requires as significant multidisciplinars effort. This effort requires entributions irom speciabs in geology and scismaligg, als well als structurat, mechanitul, wectrical. and foundation enginerering. For some time there hal been a strong

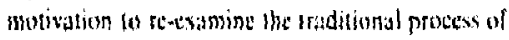

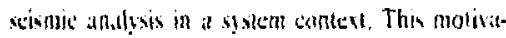

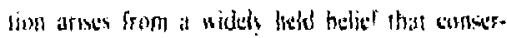
satiams compound in currenl devign

A melhodiloges that sill wamine the cortunt

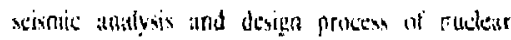

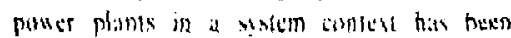
dereluped th the U.S. NKC Scromic Satets Maroin

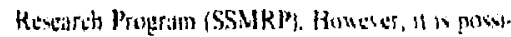
bis to consider onts the four clenenta bl the Seismic

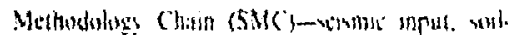

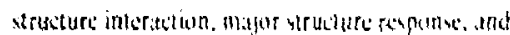

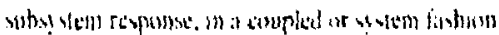
The quantines of interces are then responat potanituss.

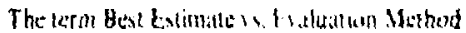

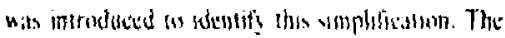
objective is to sompare mo sermo andlyok

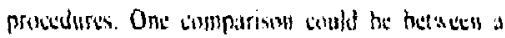
"Best fitime" Method (Bli) and in "tratuatuon"

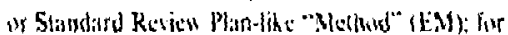

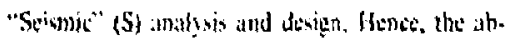

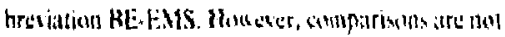

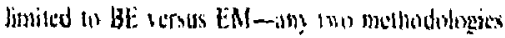
mas he complared.

A dromonstation of the Bt. EMS suncen is presemed. The exanple consisdered in lis studs finks ino dements of the SMC - xcismic inpul and

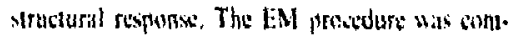

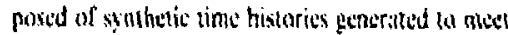


the design criteria of U.S. NRC Reguldory Guidc 1.60, the - squate-root-of-the-sum-of-the-squares (SRSS) rule of combination for response due to three companents of mation, and broadening of instructure response spectra to account for uncertainties in the dynamic chituacteristics of structures. Corresponding elements in the BE procedure were recorded time hislories-three components wilh recorded phasing, and probability distributions on structural dynamic characteristics which were sampled repetitively to incorporate struetural uncertainlies directly.

Two quantities were used in the comparison of BC. and EM response. Falctors of Comparison (FOC) weic computed as the gutient of the mean EM response spectra and the meen BE response spectrit. In iddtition. Probabilities of Exceedanee (POE) sere computed representing the probability of a BE responste excetding the corresponding EM responst. Boith the FOC and POE vily over the frequency range in inlerest. The resulls demonsirated the apparent conserwalisn of the EM design criteria subitet to the atsumptions of the studs.

Gustav A. Carlson. The Design of Tandem afirror Re'alum with Thervina Burriers, Lalurence Livermore Natunal l.ahuraturs, livermere. CA, Rept. ['CRL-8Hi]k (1980). Prepared for Proc. Fourth ANS Topicill Mecting on The Technology of Controlled Nuslear Fusion, King of Prussia, PA, OEtober 1t-17. 1980.

In at taldem mirror fistum feactor, the fusion forter is produced in the straight aylindrical central itil. The centrat-cili minntels are low-field solettonda. Because the cenlribl-cell plasma is near ur al ignition, no plasmil healing hardware is required for the central cell. A hasic desizn philosuphy for the centrall cell is thit of axial modularity, and a number of different module derigns halse heen proposed ahich lend themeleses 10 massproduction techniques,

Axjal confinement of the central-cedl lusion plasmal is enhanced hy the clectrosilitic putsonial of the plug plasmas. The incorporation ol thermal hatriers (regions of depressed potemtial between the central cell and plug plismias allows the confining potential to he crested partly by an elevatted plug electron temperature instead of soldely by a higher rlug densily. A number of different therrobil barricr configurations bave heen proposed, and are now under comparalive study. A primary connern is the determination of magnetic field shapess that will ensure magnetohydrodynamic (MHD) slibility at high central-cell $\beta$.

End-plug technologies for tandern mirror reactors include high-field supetconducting magnets, neutral beam injectors, and gyrotrons for electron cyclotron resonant heating (ECRH). In addition to their normal use for sustentance of the end-plug plasmus, neutral buam injectors are used for "pumping" trapped ions from the thermal batrier regions by charge exchange. An extra function of the axially directed pump beams is the removal of thermalized alpha particles from the reactor. The principles of tandem mirror operation with thermal bartiers will be demonstritted in the upgrade of the Tandem Mirror Experiment iTMX-U) in 1981 and the tandem configuration of the Mirror Fusion Tess Facility (MFTF-B) in 1984. Continued analysis and conceptual design over this per:ol will evolve the optimal configuration and parameters for a pouer producing reactor.

G.A. (arlonn and W.S. Acef, Ir., Tauklem Mirrer

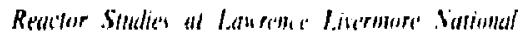

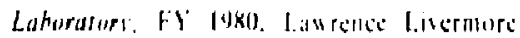
National Laborilury. Inermore. CA. Rept UCID-18989 (14:1).

The proncinles of tande'n mursur uperallown w ath thernial harriers will he demonstrated in tbe upgrade of the Tindent Mirser I verement (TMIX-Li) in 1981 and the tandem confleuralion of the Mirror

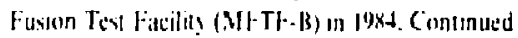
analysis ind conceptual desugln aner thas period will evolve the uptunal cumligurittenn and parameters for a power-producing retiletor. In law anticle us describe the progrese lle hate matde in tion reacter desifon stud! tffurt during 1980).

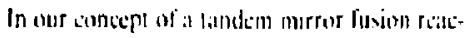
tor. the fusion porser will be produced in rive

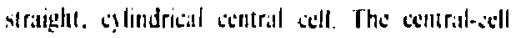

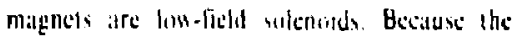

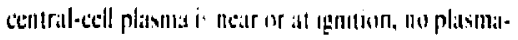
heating hardware is required lor the central cell. a

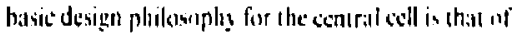
axial modularity. and a number ol dilferent modele designs have heen propustd which lend thenowelees to intiss-produdetion tethtikgutes. 
Axial conlinement of the central-cell fusion plasma is enhanced by the electrostatic potential of the end plug plasmas. The incorporation of thermal I urieress (regions of depressed potential between the central-cell and plug plasmas) allows the confining potential to be created partly by an elevated plug electron temperature instead of solely by a higher plug density. The rapidly evolving knowledge concerning landem mirrors with thermal barriers has resulted in a number of alternative end-plug configurations. Each of these con figurations is different in its ipprouch to oblaining magnetohydrodynamic (MHD) slability al high values of centrul-cell plasmil pressure, which is esscnlial for the achjerement of economically high fusion power density. MHD stahility ir il tandem mireor requires a proper ballance heiween goond maenetic field line curvalure (coneave oulward) and bad magnetic field line cursalure (comeare inward). The investigation and comparisom of thest differenl end plugs are the princlpal present efforts in our study of tandem mirror reactors.

Fnd-pluz tethnologies for tunden mirror peactors incledste tugh-field supurconducting malgnets, neutrat-heatm injectors. and gyrotrons for clectron ciclalron resomant heating (ECRH). In addition Io) thesr notmil uxe for ustentence of the end-plug plasmils. neutral-beam injeclors are used for "pumping" Irapped wans fron the thernial batrier regions by charpe eschange. An curra function of the encull! directed nump heims is the remowal of therm.sised alpha part:

D.W. Cogls, R.C. Murray, and D.L. Bernreuter, Ifetheds for Develusing Scismic and Extreme Wimd Hazard Modeds for Evaluating Critical Sinctures

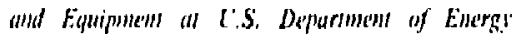
Facilitis and Commercial Plutomium Facilities in the Cinted States, Lalurence Lirermore National J.uhoritt)ry. Livernors. CA. Rept. UCRL-85+51) 119k1). Brepiared lor the fih Intern. Conf. on Sirutfural Meclanisis in Reactor Tethnoldagy, Paris, Francic. Auguti 17-21, 1981.

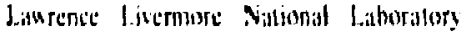
(ILNL) is dexeluping seismic and wind hazard mi dels for the L.S. Departmem of Energy (DOE). The work is part of a three-phase effort lo restablish huilding design crituria developed with a uniforn muthodology for seismic and wind halrateds at the vilrious Dol: siftes lhroughout the linited States, In
Phise I, LLNL gathered information on the sites and their critical facilities, including nuclear reactors, fuel-reprocessing plants, high-level waste storage and treatment facilities, and special nuclear material fucilities. Phase 2-development of scismic and wind hazurd models-is discussed in this paper, which summarizes the methodologies used by seismic and extreme-wind experts and gives sample hazard curves for the first sites to he modeled. These hazard models express the annual prohibility that the site will experience an earthquake (or windsperd) grester than some specified magnitude. In the final phase, the DOE will use the harards models and LLNL-recommended uniform design criteria to evaluate critical facilities. The methodology presinted in this parper allou wils used for a relaled LLNL study-involsing the seismic alsessment of six commercial plutonium fabrication plints licensed by the U.S. Nuclear Regulators Conmission (NRC).

C.A. Cornell, W.K. Ravindra, and C.K. Chou,

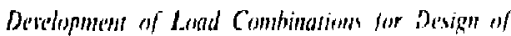

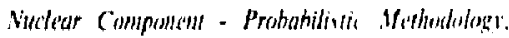
Lawrence Livermure National Latheratur! Liter-

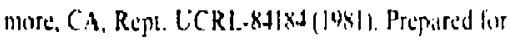
the fith Intern. Conf, on Structural Methanice in Reactor Technolngẹ, Paris, lerance. Auguse 17-21. 1981.

Prowedures ate dexirthed fin the walututh of

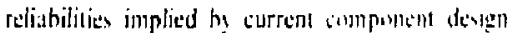

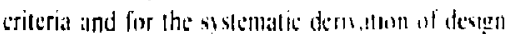
criteriat that athieve specified lated cimponemt reliatilities, The proposed method of calculateng the

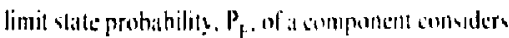
the uncertaintion of Joad procenses and somponent resistinces. The probalility distritution of the extreme combined renponse is dec chinged hy coms ols-

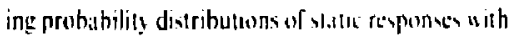
the currente of the combined lome t.treing do noumic

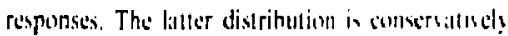

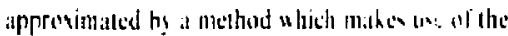
mean uperossing ritte (ins functions al the response

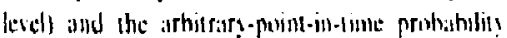
density functinns of the individual reapunese. The probahilizy of Ilecemponent reichng a limit state is the probubility that the combined masimum response exceds the compoilent resistince. A representitsice sumple of compontum designted in iccordanee with il set of desien critcrial will haver a 
frequency distribution of $P_{F}$ that represents the limit state probability implied by the criteria set. This technique of reliability evaluation of design criteria can be used to plate a new load and/or a new load combination in the proper service level category.

The design eriterias are derived such that the components of a particular class have approximately the sume linit state probabilities. The Load and Resistance Factor design (LRFD) formit. cquation (18), which is a generic form of mosi current mechanieut and struclural design eriteria is selected as appropriate for load combination methodology development. The load and resistance factors are selected using an optimization procedurc whercin a function of the difference between $P_{F}$ and the target limit state probability, $\mathbf{P}_{\mathbf{T}}$, is minimized over the ciass of components.

D.X. Cotnish, Superconductivity and Crịgentics for Mirror fusion. Lawrence Livermore Nutional Liboratory. Livurmore. CA, Rept. UCRL-83916 (1980),

A brief introduction to the matinline experienents being presently pursued in mirror fusion restarch is followed by a more decailed description of the trogegenic and stiperconductive ispects of the Mirros Fusion Test Facility (MFTF) and its exienvion to a landem mathine. The large volume of mingetic field required for confinement has a maximum inlensity of close $10 \times \mathrm{T}$ and is produced by il sariely of suptrconducting magnels. $A$ large and somplex cryogenic system is necessury to provide the $t \cdot K$ ens isonment for these coils and 10 meet the laree cropumping needs of the mathine.

C.C. Damm, J.N. Doggett, R.H. Bulmer, W.S. Yeef, C.W. Hamilton, A.E. Sherwood, S. Szybalshi, B.M. Boghosian, G.A. Carlson, R.W. Moir, W.L. Burr, J.L. Efickson, R.W. Devoto, T.H. Batzer, and C.I. Hanson. Preliminary Design of " TandemMirror-Nev-Step Focility, Lilwsence livermore National Lahosatory, Livermore, CA, Rept. UCRL.53060) (19K0).

The Tandem-Mirror-Next-Step (TMNS) Facility is designed to demonstrate the engineering feusibility of a tandem-mirror reactor. The facility is hilsted on a deulerium-Ititium (D.T) burning, tandem-misror device with a fusion poner oulpul of $245 \mathrm{NW}$. The fusion puret densily in the central cell is $2.1 \mathrm{MW} / \mathrm{m}^{3}$, with a resultant neutron wall loading of $0.5 \mathrm{MW} / \mathrm{m}^{2}$. Overall machine length is $116 \mathrm{~m}$, and the effective central-cell lengh is $50.9 \mathrm{~m}$. The magnet system includes end cells with $Y$ inYang magnets to provide magnetohydrodynamic (MHD) stability and thermal.barricr cells to help ilchiuve a plasma $Q$ of 4.7 (where $Q=$ fusion power/injected power). Neutral beams at energies up to $200 \mathrm{keV}$ arc usted for plasma healing, fueling. and barricr pumping. Electron cyclotron tesonant heuting at 50 and $100 \mathrm{Gll}$ \% is used to control the elcetron kemperalure in the basriers. Based on the resulting engineering design, the overall cost of the facility is estimated to be just under $\$$ I billion. Un. resolved physics issues include central-cell $\beta$-limits algainst MHD ballooning modes (the assumed ruference value of $\beta$ exceeds the current theoryderived limit). ind the renowal of thermalized $\alpha$ particles frou the plasma.

John I.. Frickson, Irving L. Ojalvo, and John 0. Myall, Siructural Suppurt of a Yirr-Youg Magnes for a Tundem Mirror Reactor with Tharmal Barriers. Lawrence Livermore National Laboratory, Livermore. CA. Ript. LCRL-8423+ (1980).

Concepenal designs of mirror power reactors hate historically used high-field magnets that required missive restraining strutetures, in addition 10 the hasic coil calse, to support the electromagnetic louds. Recentli. application of the thermal barrier concept to landen mirfors bess sufficiently improved reactor performanse such that a Yin-Yang reactor mignat may not fequire significantly higher technology than is required for the Mirror Fusion Tes Faciliny (MFTF) Yin-Yang coils. The approach taken in our study was lo ust a simple coil case of compace design and 10 add and modify structural members to transfer loads from one coil to the other. It has heeft issumed that the magnet issembly will resemble the MFTF design. The structuril material selected is $3(1+\mathrm{LN}$ stainlesis stect with it yiteld stress of $120 \mathrm{ksi}$ it $+K$. The niohiumlitanium conductor is assumed to be of square cross-xection to allow winding in luo planes. This s'pon contains a conmonthensive summary cotering nork performed by Grunuman Acruspice Corporition, in conjunction with the Lawrence Lirermore Nitionial Laboratory, on the TMP Yin-Yang coils. The Yin-Yang coil pair used for our andlysis has a major are radius of $2.7 \mathrm{n}$ and a minor are radius of 
$1.18 \mathrm{~m}$, compared with $2.5 \mathrm{~m}$ and $0.75 \mathrm{~m}$ for the MFTF. The maximum field on the present conductor is $9.05 \mathrm{~T}$. This magnetic field is created by, and interacts with, a conductor current which produces a 360 million Newton total force. tending to separate the parallel lohes of the major arcs.

A. Goldberg, S.L. Albertsom, and Irene A. Fedrick, Characterization and Evaluation of a Turbine Disc Section Comlaining a Senice Crack, Lawrence Livermorc National Laboratory, Livermare. $C A_{\text {. }}$ Rept. UCID.18699 (I98I).

Cracking had occurred in the keyway of a lowpressure uurbine disc. We evaluated a section of the disc to determine whether the tensile and Charpy $V$ notch (CVN) toughness properties in the hub region corresponded to those originally specified for this disc. We also characterized the microstructure of the steel and intaly, $\rightarrow d$ the bore surface. Roomtemperature tensile p. pperlies and FATT $_{50}$ were found to be essentially unchanged from the specified values. The stcel was relatively clean. However, excessive segregation was present and was reflected by variations in grain size. microhardness. sulfur distribution, and inclusion content, Using V-Tal analysis, we identified the presence of an Mus $\mathrm{S}_{2}$ deposit and an $\mathrm{FeCr}_{2} \mathrm{O}_{4}$ corrosion film along the bore. We propose that excessive segregation (intusions, alloying elements, embritling consiluents) contributes to excessive scatter in our CVN results, Segfegation and $\mathrm{MoS}_{2}$ lubricant may hoth contribute to the cracking problem.

\section{L.C. Green, E. James, E.L. Lee, E.S. Chambers,} C.M. Tarver, C. Wesmoreland, A.M. Weston, and B. Brown, Delayed Detonation in Propellants from Low Velocitl Impact, Lawrence Livermore National Laboratory, Livermorc, CA, Repl. UCRL-84999 (1981). Prepared for the 7th Symp. (Intern.) on Detonation, Annapolis, MD, June 16-19, 1981.

Certuin high HMX-content propellants are found to undergo delayed detonation when eylinders of the propeilant are subjected to ixisymmetric impact. The magnitude of the impact pressure is considerably less than that required for prompt shock initiation. It is also found that granular prosedlant (65-78\% theoretical maximum density) packed in a. thick-walled $(50 \mathrm{~mm}$ ) Plexiglas pipe is taisily delonated by relatively law-velocity (130 m/s) piston compaction of the porous propellant. The above processes appear to be related to each other and to the more classical deflagration-to-detonation studies carried out in heavy-walled pipes where the explosive is deliberately ignited to start the build-up to detonation.

\section{R.S. Hawke and A.L. Brooks (LLNL), and C.M.} Fowler and D.R. Peterson (Los Alamos), Electromagnesic Railgun Launchers: Space Propulsion Applicalions, Lawrence Livermore National Laboratory. Livermore. CA. Rept. UCRL-85007 (1981). Prepared for AlAA/JSASS/DGLR 15th Intern. Electric Propulsion Conf., Las Vegas, NV, April 21-23. 1981.

Considerable progress in understanding rijlgurl operation, requirements, and limitations has been made. It appears that railguns may have potential application to space propulsion and direct launch. This paper discusses the state of the arl and expected cupjability of railgun systems. It includes the rcquirements and an example design of an earthbased system capable of launching projectiles through the almosphere at velocities greater than $8 \mathrm{~km}_{f} / \mathrm{s}$. The critical issues and problem iseas that require investigation are described.

\section{C.D. Henning. The Economic Potential of Magnetic} Fusion Energy: Luwrence Livermore National Laboratory, Liwermore, CA. Repl. UCRL.84938 (1981).

Fusion energy is a virlually inexhaustible resource in which light nuclei fuse 10 produce hoavier nuclei and energy. as evidenced by radiation from the sun and the stars. While many exothermic reactors are possible, the most accessible uperating conditions are found for in deuterium and tritium mixture. As a later development, pure deuterium fuels in high temperature mirror reactors might obviale the need to treed tritium, or perhaps a deuterium-helium III cycle could be used to eliminate most of the reaction neutrors and induced radioactivity in surrounding structures. Scientific feasibility of mugnetic fusion is no longer seriously in doubt. Rapid advances have been made in both Tokusnak and mirror research, leading to a demioristration in the TFTR Tokamak at Princeton in 1982 and the tandem mirror MFTF-B al Livermore in 198;. Actordingly, the basis is established 
for an aggressive engineering thrust to develop a reactor within this century. However, care must be taken to guide the fusion program towards an economically and environmentally viable goal. While the fusion fuels are essentially free, capital costs of reactors appear to be at least as large as current power plants. Accordingly, the price of electricity will not decline, and capital availability for reactor constructions will be important. Details of resctor cost projections are discussed and mechanisms suggested for fusion power implementation. Also discussed are some environmental and safety aspects of magnetic fusion,

C.D. Henning, A.J. Hodges, J.H. VanSant, E.N. Dalder, R.E. Hinkle, J.A. Horrath, R.M. Scanlan, D.W. Shimer, R.W. Baldi, and R.E. Tatra, Mirror Fusion Test Facility Magnet System-Final Design Report, Lawsence Livermore National Laboratory, Livermore, CA, Rept. UCRL-52955 (1980).

The Mirror Fusion Test Facility (MFTF) is the largest of the mirror program experiments for magnetic fuston energy. It seeks to combine and extend the near-classical plasma confinement achieved in 2XIJB with the most advanced neutral beam and magnet technologies available. The product of ion density and confinement time will be improved while the superconducting magnet weight will be extrapolated from 15 tons in Baseball II to 375 tons in MFTF. Other project parameters show that the MFTF will traverse much of the distarite in magnet technology towards the reactor regime. Authorized to start construction in FY 1978, the MFTF project is close to its schedule for completion in October 1981. Following a change in geometry at the end of the preliminary design stage, detailed design was commenced in May 1978. By August of 1979 the design was complete and the first roil construeted. The second coil was finished in Marth 1980, Final assembly, including the case structure. vill be completed and ready for testing in early 1961. An extension of the project called MFTF-B has been authorized and will delay project completion three years.

R.W. Hoard, R.M. Scanlan, G.S. Smith, and C,L, Farrell, The Effect of Strain on the Martensitic Phase Transition in Superconducting $\mathrm{Nb}_{3} \mathrm{Sn}$, Lawrence Livermore National Laboratory, Livermore, CA, Rept. UCRL.84211 (1980).
The connection between the cubic-10tetragonal martensitic phase transformation and the phenomenon of superconductivity in Als compounds is being investigated. The degradation of the critical paramete.s, such as $T_{c}, H_{c 21}$ and $J_{c}$ with mechanical straining is of particular interest. Since martensitic transitions are also known to be strain sensitive, perhaps the structural change is directly responsible for the reduction in superconducting properties, We performed low-temperature x-ray Jiffraction experiments on $\mathrm{Nb}_{3} \mathrm{~S}$ ribbons (with the bronze layers etched of? mounted on copper and indium sample stages. The cryostal we used is unique in that it has a vacuum mechanical insert which allows the superconductor to be placed under both compressive and tensile strains while at low temperatures. Preliminary results indicate that the marlensitic phase transition temperature $T_{m}$ in creases with compressive strains. Other effects of struin on tetragonal phase production ase also discuissed.

J.J. Johnson, G.L. Goudreau, S.E. Bumpus, O.R. Maslenikar, T.Y. Chuantg, T.Y. Lo, B.J. Benda, and P.D. Smith, Seismic Response Calculations for the U.S. NRC Seismic Safety Margins Research Program, Lawrence Livermore National Laboratory, Livermore, CA, Rept. UCRL-84194 ([981). Prepared for the 6th Intern. Conf. on Structural Mechanics in Reactor Technology. Paris. France, August 17-21, 1981.

The seismic analysis and design of a nuclear power plant requires contributions from specialists in geology and seismology, as well as structural, mechanical, electrical, and foundation engineering. For some time there has been a strong molivation to re-examine the truditional process of seismic analysis in a system context. This motivation arises from a widely had belief that conservatisms compound in current designs. That is, at each stage. conservatisms are introduced to account for uncertainties, and these conservatisms compound from one stage to the next. Presently, only minimal compounding emphusis is placed or this because the conservatisms are not quantified.

A methodology that will examine the current seismic analysis and design process of nuclear power plants in a system context was developed in the U.S. NRC Seismic Saticly Margins Research Program (SSMRP). Examining the tolal plant, in- 
cliding the functional reguirements of operating and safety systems and their interdependence, is the musl complete marne" of addressing the various issues, an' this is the SSMRP approuch. The systems inalysis approuch encompansss the entire Seismic Methodolcyy Chain (SMC), the systematic representation of the nurleur power station's reactor systems using event/fault tree methodology. a description of the fragility of structures, components. and systems due to seisnic loading conditions, und a computational approach which computes the probability of fialure of struelures, components. and systems and the probability of radioactive releuses. This report describes the methodolngy used is the SSMRP to determine the seismic responses and their variability to be input to the stslems analysis program SEISIM.

The computer program sMaCS (Seismic Methodology Analy sis Chain with Statistics) was developed to link together the seismic input, soilstructure interaction (\$SI). major structure response. and sthssistem response calculutions. The response deternined with SMACS is the input to SEISIM. Hence. a compatibility helween the responses and the fragility descriptions of structurus, components, and systems must be maintained.

The SSMRP response caiculations should be as realistic as possible and uncertainties should be modeled using probabilistic methuds. Eest estimate models of the ent ire SMC were used. Uncertainty in each phase was incorporated us follows: In the sessmic input. the largest source of variability was incorporaled through ensembles of tine histories; in the SSI phase. the mechanism to inciude variability was the shear modulus and damping in the soil: in the structures and subsystems stages, variations in the frequencies and mudal damping pruperties were the mechanism. These variations were treated in SMACS. Next, the response calculations must be performed for a range of excitation levels reflecting the fact that the systems analysis yields the probability of failure and radioactive release for the earthquake hazard which includes earlhquakes of sinali amplitude up to very large events.

This report presents a summary of seismic responsc calculasions for SSMRP Phase I including inpul parameters, their variability, and rusults of the culculations.
J.F. Lee, D.L. Chapir, and J.W.H. Chi, Parametric Systems Analysis for Tandem Mirror Hybrids, Lawrence Livermore National Laboratory, Livermore, CA, Rept. UCRL-84248 (1980). Prepared for Proc. Fourih ANS Topical Meeting on The Technology of Controlled Nuclear Fusion, King of Prussia, PA, October 14-17, 1980.

Fusion lission systems consisting of lissile producing fusion hybrids combining a tandem mirror fusion ariver with variouss blanket types and net fissile consuming LWR's have been modeled and analyzed purametrically. Analysis 10 date indicates that hybrids can be competitive with mined uranium when $\mathrm{L}_{3} \mathrm{O}_{8}$ cost is about $100 \mathrm{~s} / \mathrm{lb}$, adjing less than $25 \%$ to present-day cost of power from LWR's. Of the three blanket types considered [uranium fast fission (UFF), thorium fast fission (ThFF). and thorium fission suppressed (ThFS)] the ThFS blanke! has a modest economic idvantage under must conditions but has higher support ratios and potential safialy advantages undet all conditisns. Uncertainties in tundem mirror mudeling caused about a factor of 2.5 swirig above and trow

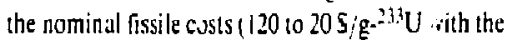
ThFS blankel). which in turn results in less than a $20 \%$ swing in electricity cost (57 to 39 mjills $/ k W \cdot h e)$.

J.D. Lee, R.A. Engholm, D.J. Dudziak, and R.C. Haight, Fusion Reactor Nuteonis: Slanus and Needs, Lilwrence Livermore National Laboratory. Livernore. CA. Repr. UCRL.84574 (1980). Prepi red for Proc. Fuurth ANS Topical Meeting on The Technology of Contolled Nuclear Fusion. King of Prussia, FA, Oclober 14-17. 1980.

T're national fusion technolog! effort has made a good sturt at addressing the basic nucleonics Issues, but only a start. No fundamental nucleonics issues are seen as insurmountable barriers to the development of commerciali fusion power, To date the fusion nucleonics effort hals relied almost exclusively on other progrums for nuclear data and codes. But as we progress through and beyond Enginerring Test Facility (ETF) type design studies. the fusion program will need to support a broadbased nucleonics effort including code develonnent, sensitivity studies, integral experiments, i 
acquisition, etc. It is clear that nucleonics issues are extremely important to fusion development and that we have only scralched the surface.

\section{J.D. Lee and R.W'. Moir, Fission-Suppressed} Blankess for Fissile Fiul Brevding Fusien Reactors, Lawrene Livermore National Laboratory, Livernore, CA, Rept. UCR L-84104 (1940). Prepared for the Journal of Fusion Energi:

Two blanket concepts for DT fusion realutors are piesented which nadximi/e fissile fuel production while at the sisme time they suppress fission reactions, By- suppressing lission reictions the realwor will he less bizardous, and itherefore casier 10 designe. develop. and licensit. Also, by suppressing fission reactions, such a fusion hreeder operating it a given nuctear pors er level cen produce much more Fissile futl. The imo hlankets described both use beryllium (Bu) for neutron muliplistition. One uses ince etrarate circulating noller salle: ane salt for

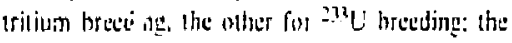
stcond unes separatte solid forms of lithium and thorium fur hreeding and is holiumscumbed.

O.R. Maslenikor, J.C. Chen, and J,J. Johnson.

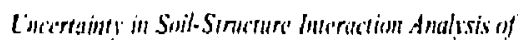

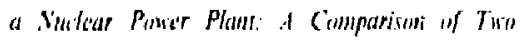
Analysis Protedures, laturewe Livermore Nationa! Laboratory, livermort. CA, Rept. UCRL-85702 (1981). Prepared for the fith intern. Conf. on Structural Machamics in P.ctilctor Technologet. Paris. Francic. Augus 17-21. 1981.

Predicting ihe stinnic responst of atiff, malssive structures, iuch as those found att al nuckeir pounce plant, accounting for the effect of soil-structure in. leriction (Sst). is subjest lo a number of uncertainties. A principal surece of uncertainty conties from differences in SSI anily sis lechmiques. This uncertainty inde. in particulitr. late idealizalion of the soilstructure ststem, is the subject of this uistussion.

The sludy from which the milterial discussed herein is taken is part of the U.S. NRC Scivms Sifcigy Martins Restarch Propran (SSMRPI. The SSMRP is deceluping probishilistic methods that nore reatistically estiniale the hethatrior of nuclead pow er planti during carthguakes. A demonstration of the SSMRP methodology is being performed on the Zion nuclear pow tr vation in Zion, lilinois, USA. The plant ansists of two NSSS units with at power rating of $1100 \mathrm{MW}(\mathrm{c})$ each. In lerms of $\$ S \mathrm{~S}$. three bissic structures exist-two resctor containment buildings, each with its own foundation, and the iluxiliary, fuel handling. and furhine gentrator huilding complex supported on a foundation of varying elevation and thickness. The latter compilex is also tied logether by continuous slabs and walls in the upper slories. The SSI analysis of the complett Zion nuclear fouer plint is the subject of the present study: the discussion of this piper is limited to one ispece of the sludy-the analysis of a single isolatted reactor building.

Two alternitive techniques wert alplied. The first wass a lintilr linite element alpproach using the computer program FLUSH. The significint dynamic tharacteristits of the structures were modeled hy sets of single degrex-or-freedom models with approprjate milss. stiflness, and damping characteristites. Responst wis oblained at the basemat level of the FLUSH nodel. A second stage structural analysis was performed to compute detailed structuril reponst. The securd nethod was is subsiructure approath using the compuner progrann CLASSI, which is, in generiol, thretdimensional and permits detailed structural models to be incorporaled into the analysis, The dy namic characteristicis of the reatur huilding structures were represented hy their modal propercies, and SSI etfects 1 ere included als foundalion innur motions

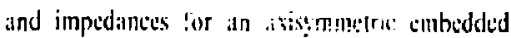
foundation.

Basemat and in structure responst at selected points were obtained from the FLUSH and CLASSI analyses in the Form of palk calues and response spectea. The resulls compiled sery well with differences in poak values generally averighing absut fise pereern and spectral implitude varlations of lexs than thirty percent. $\lambda$ comparison of retults from second stige analyes ahich omilled the hasemat rocking componstit shous d thill significant shifts in frequencites of spectral peaks occurfed and thatt، in getleral, the elfect of umitling rocking tainnot he predicted. The prohlem studied iterein reptissents a very simple one in terms of differences in itsimptions notde for the CLASS! ind FLUSH analyses. Mare coniplicaled problems involving complex structures and multiple foundations are the subject of the remainder of the study and are expected to result in much greatur variations between the two nethods. 
E,W. McCauley, H.J. Weaver, and T.J. Altenback, A Methud for Chug Classificotion. Lawrence Ljvermore Nittionill Laboratory. Livermore. CA, Rept. UCRL-85707 (|98|). Prejared for the ist Intern. Spcicialists Mfeeting on BWR-Pressurc Suppression Cuntiinnent Technology, GKSS Resturch Center. Getsthachi, Federal Republic of Geematly, June 1-3. 1981.

A nethod is presented which sly sifics the late imle condensation phenemental of chugging as it occurs in pressure suppresson iests. The method uses a five (5) thisracter letter code which describes both the spectrat (frequency) and kemporal characteristics of a chug went.

R.C. Murray, 1.A. Yelson. D.W. Coats, D.S. Jg. and H.J. Weaver. Impa.l of the Janury-Februar!

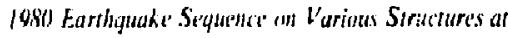

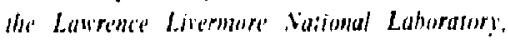
Laimrence Livernore Natumall Lahorator!, Liser-

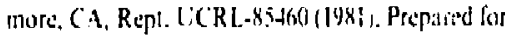
the finh Intern. Conl., an Strusturil Methanics in

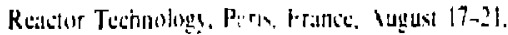
1981.

On Januilry 24. 1981). Californias Livermore

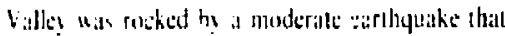

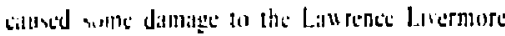
Sittural taherators (II) VLI. The earthquake. which meavured 5 s. on the Richler male and was cuntered :thous 2il km (12 mi) nurthases of the

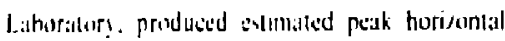

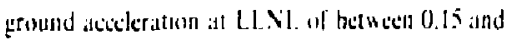
0.3 . The warthyuake wis part of a sequence that

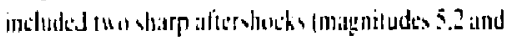
4.2) within 1.5 minutes of the int ial ex:ent. A steond

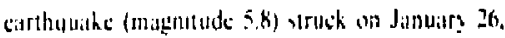

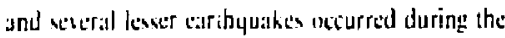
me'sl tell witks.

Dirnalge resulted primasrily from the Jintur? 2t carthquake with extmlates of is impact ranging ujmard tw 515 millien. meluding 5.3 millien in direel datmage and $\$ 12$ milliun in upyrading coss.s. Five facilities that house ippretiothle amounts of radhatise inaterials suffered essentially no strac-

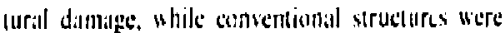
dilliatged. This diflerence reflests differences in desiegn criteria.

This paper decerrites the damage impatt of the Jallualry 24 earlbiquikt. including:
- Background information on LLNL.

- Discussion of pre-earthquike seismic sarely philosophy,

- Description of the impact of the January $2 i$ earthquake, including a description of the seismic setting of the Laboratory, a discussion of the ground motion, and a summiry of damage.

This pap:r also describes al data gathering and reduction effor: at LLNL in the aflermath of the January surthyuakes, In anticipation of additionlal aftershocks, stvera! baildings and structures wert: equipped with devices to munitor furilding response. Ditla were recorded for hoth the Febrealry I? and 2 l ifftershocks, which niedsured 2.0 on the Richler scille. The data "were primarijy used to delermine peak acceler ations: hewcter. we also used computer programs develoned al LLNL to cxtracl infurnaison aboux the structural dynimic behavior fron! velocily time-history signals. An unalyss of one building is prestned to show the usefulness of the technique in identifying the principal vbrator! modes of a sitructure and the freculencies and damp. ing vilues of these modes. The potential of the lechnique for monituring changes in the xis walls sulnerethilits of cortical atructures in discumed

Pagl D. Smith and Richard 6. Dong. Scismm Sorker

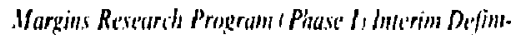
tiall of Terms, Lawrence Livermore Katlinmal

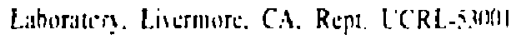
(1980).

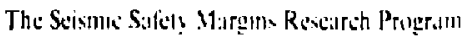

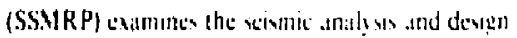

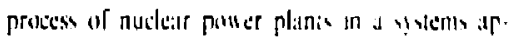

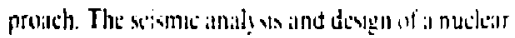

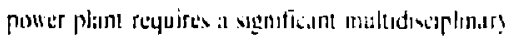
efforl. This eflort requirs contributions Irnon spectialists in gevolog! scismologs: and tructuril.

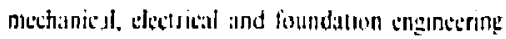

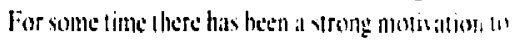
reevinine the traditional process of seismlic analy so in a systems contex. This motication arress prinsupally from a widely held belief that comstratusm

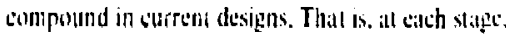
consersatisnss are introduced to account for uncertainties, and thesc cambersatisms compound from

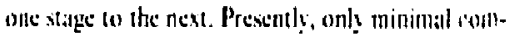
pinsilions for compounding are made in ciach state

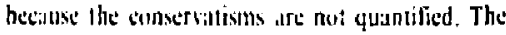
result mat be an orer-consersatise seismic design. 
The objectives of the Seismic Safuly Marțins Rextarch Progrim (SSMRP) are to estimatc the denres of consersalism of the prestnt Standard

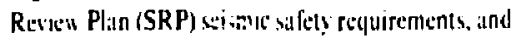
10 develop improved reçuirements and methods for saftei! asswontent.

Richard W. Werner. The Tandem Murror Resctor as a Simbetir Fuel Perducer. Lawrence Livermorc National Luburator?. Livermore. CA. Rept U(CL-\$3536 1 1480) Prepared for Pros. Fourth ANS Topical Meetung on The Technolug! of Conirolled Nucteat: Fubon, King of Prinsiia, PA. Oswhet 14-17. 1980

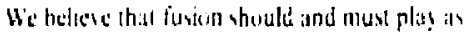
srong a rake in the production of fust and chemicil

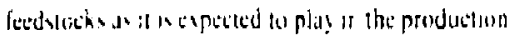

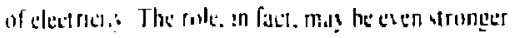
unce the produsiunn of fuel in the forme of

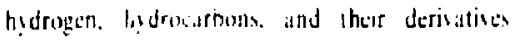

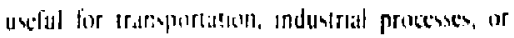
for resudenthal and cummercial use or the produc

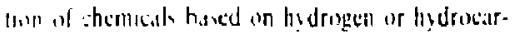

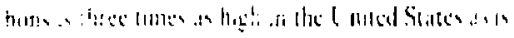

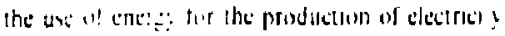
He further hellese that fuci productum is net in-

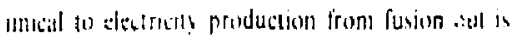

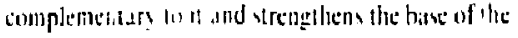

entise fusion program. We fepert on al scoping design of a fuswon revetor basted on tindeln mirror physes coupled to thermothemical procenies for the production of hydrigeter.

J.P. Zhasnik, ID.X. Cornish. R.M. Scantan, A.Y. Jemell, R.I. I.eber, A.R. Rosdahl, and M.R. Chaplin. Buskigromd Fidd Coils lor the High Fichl Test Farilits, Lam fence livermore Nallumal Lathoritory, Lisermors, CA, Rept. UCRL-Ǩ517? $\{1981\}$.

The High Fielo i est Fastility (HFTF), presensly under consiructure at LLNL. is a vel of supercosnducting coils that will be used to test |-mo-id.d. corih of protolepe conductor kor lusion magnest an fieddr

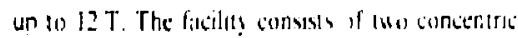

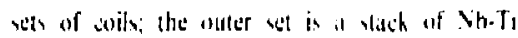

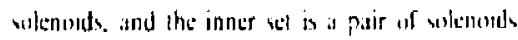

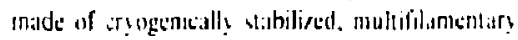

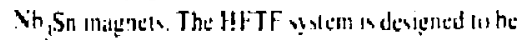
parted alung the modplance willow high-ficld couldutors under desclopment for Tokarnak luswn

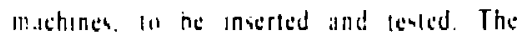

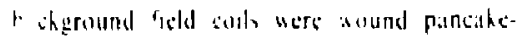

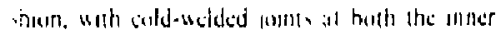

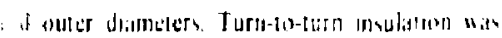

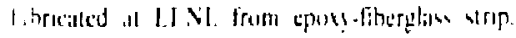
Ine comle nere inembled and levited on ene 2-mdiarle erbastat lin serift their operatlun. 